\title{
Optimization of Anaerobic Membrane Bioreactor Operation for Brewery Wastewater Treatment
}

by

\author{
Han Chen \\ A Thesis \\ Presented to \\ The University of Guelph \\ In partial fulfillment of requirements \\ for the degree of \\ Master of Applied Science \\ in \\ Engineering
}

Guelph, Ontario, Canada

C Han Chen, January, 2015 


\begin{abstract}
Optimization Of ANAERobic MEMbrane Bioreactor OPERATION FOR BREWERY WASTEWATER TREATMENT
\end{abstract}

Han Chen

University of Guelph, 2015
Advisor:

Dr. Sheng Chang

The micro-brewery business has been subjected to rapid growth within the last decade. Most brewers are facing expensive wastewater compliance bills and are seeking reliable on-site treatment methods. Anaerobic membrane bioreactor (AnMBR) treatment is favorable to the widely used upflow anaerobic sludge blanket (UASB) method. It offers high quality effluent free of solids, and has great stabilities under loading shocks. To date, there have been limited submerged AnMBR studies and none have been conducted on brewery wastewater. In this research, a state-of-the-art AnMBR laboratory scale system was used to investigate the performance and capability. The system was subjected to 230 days continuous operation with both synthetic and real brewery wastewater at organic loading rates (OLRs) ranging from 2 to $11.5 \mathrm{~kg} \mathrm{COD} / \mathrm{m}^{3} /$ day. While the system demonstrated an excellent biological performance, the study found that the major limitation of AnMBR was the membrane fouling, which increased with the OLR and soluble microbial products (SMPs) in the mixed liquor. 


\section{ACKNOWLEDGEMENTS}

I would first like to express my deep appreciation to my advisor, Dr. Sheng Chang for his valuable guidance and support.

I also would like to thank my advisory committee member, Dr. Hongde Zhou for teaching me the fundamentals in wastewater treatment.

I would like to thank my parents for their unconditional love and endless support throughout the two years.

I would also like to thank all my friends for their supports in the past two years. Special thanks go to Xiaoyan Chen, Adam Moore and John Cloutier for their friendly and technical supports.

Finally, I also like to express my thanks to GE Water and Process Technologies for the support of AnMBR pilot system and in-kind scholarship, as well as to the technical supports from the company members: Youngseck Hong, Martha Dagnew and Isaac Klassen. 


\section{TABLE OF CONTENTS}

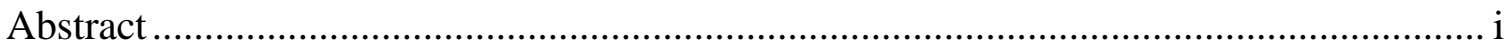

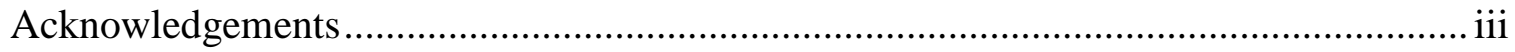

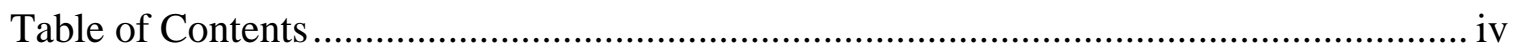

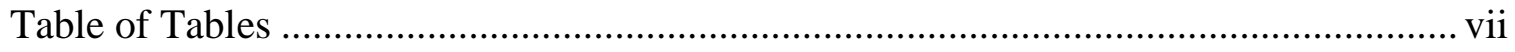

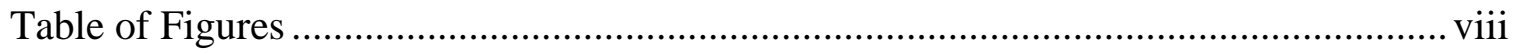

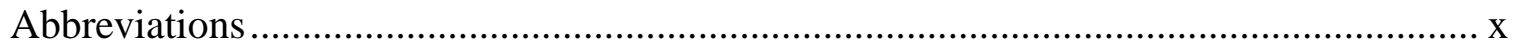

CHAPTER 1 - $\quad$ Introduction ........................................................................... 1

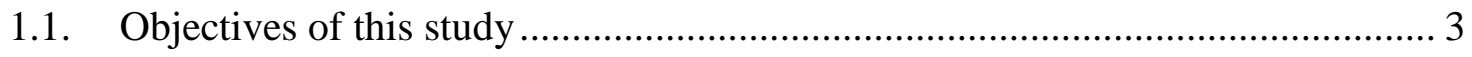

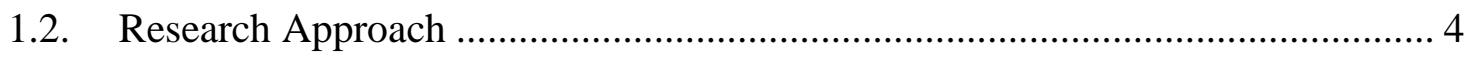

1.3. Thesis Organization...................................................................................... 5

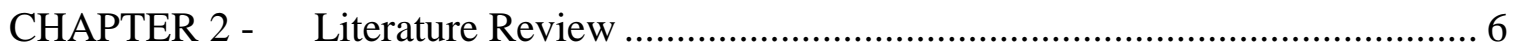

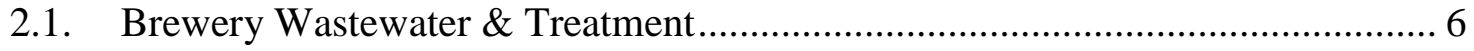

2.1.1. Brewery Wastewater Characteristics ..................................................... 7

2.1.2. Wastewater Treatment for Micro-breweries in Ontario............................. 10

2.1.3. Anaerobic Treatment and Limitation of Conventional Methods ................ 12

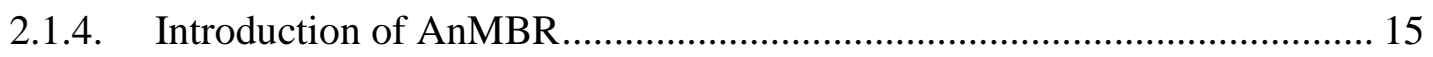

2.2. AnMBR in The Food and Beverage Industry ........................................... 19

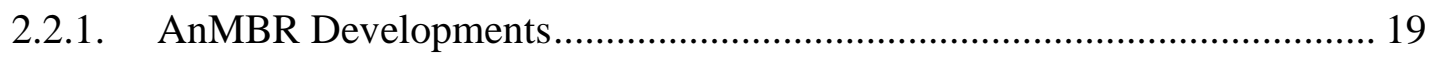

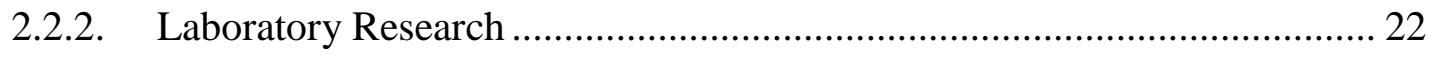

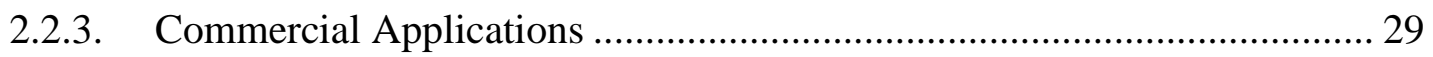

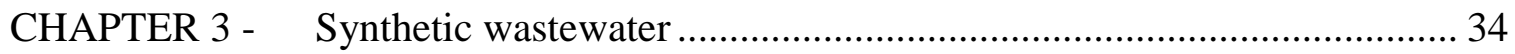

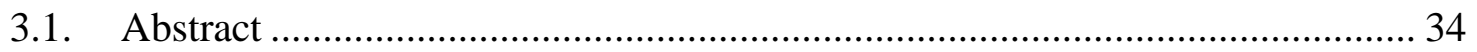




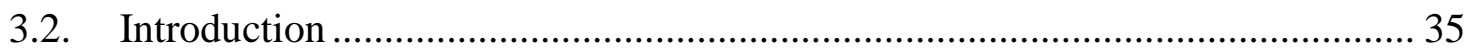

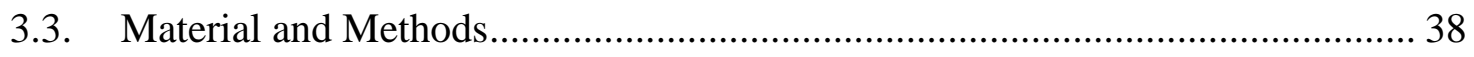

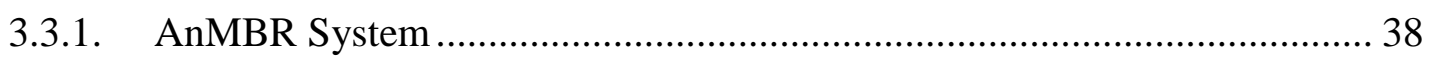

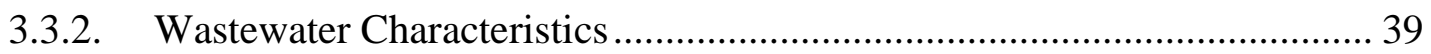

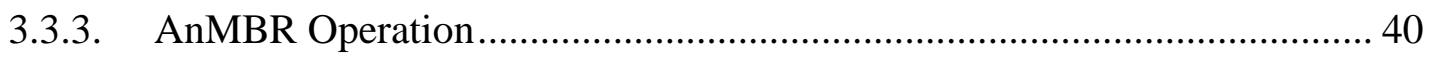

3.3.4. Bench Scale Filtration System ................................................................... 41

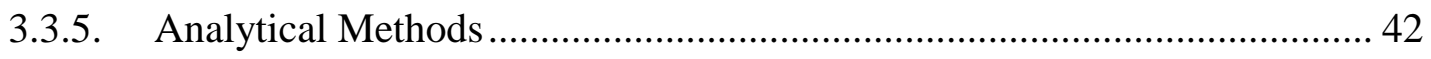

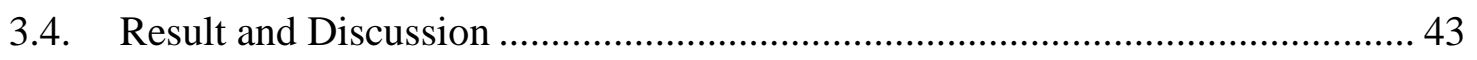

3.4.1. System Performance …………………………....................................... 43

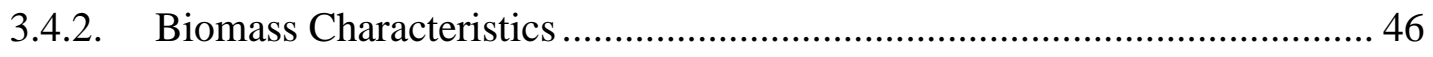

3.4.3. Soluble Microbial Product Characteristics ................................................... 47

3.4.4. Membrane Filtration Performance ............................................................ 50

3.4.5. Bench Scale Filtration System ................................................................. 53

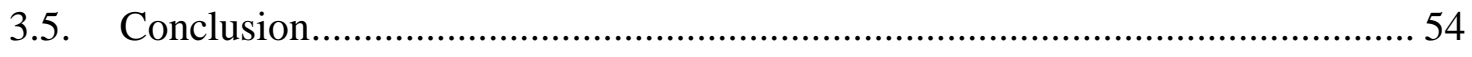

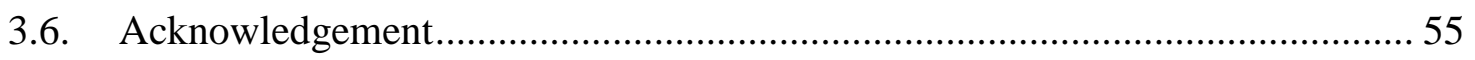

CHAPTER 4 - Local Craft Brewery wastewater ………………………………….... 56

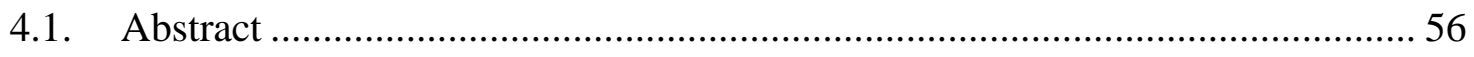

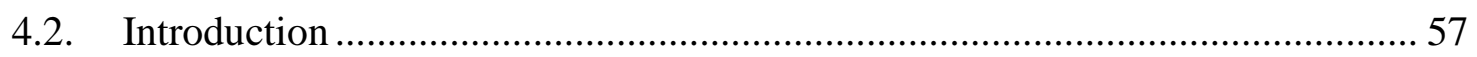

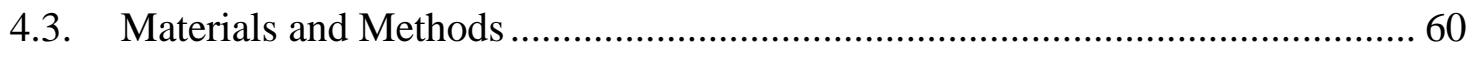

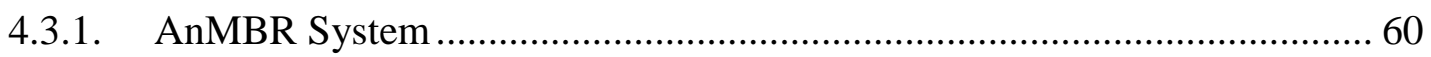

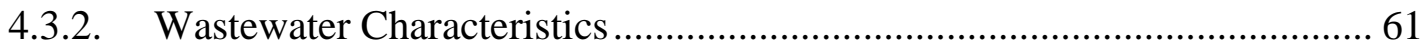

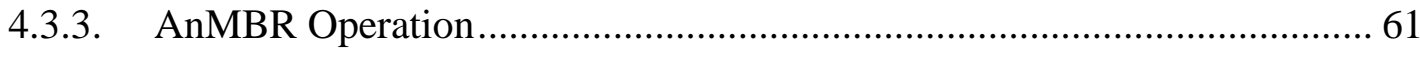

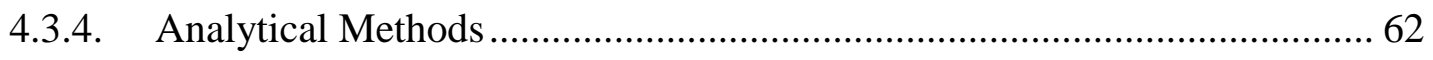

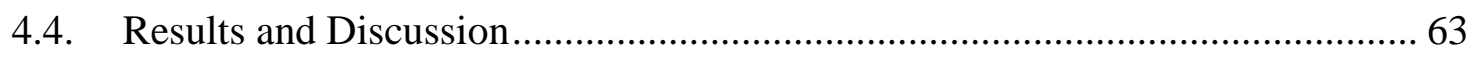

4.4.1. Brewery Wastewater Characteristic............................................................ 63 


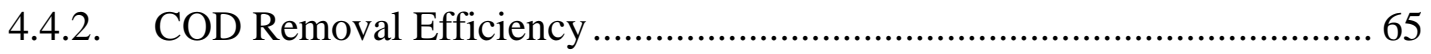

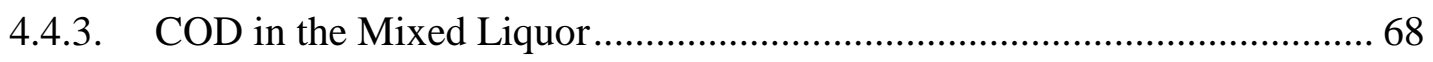

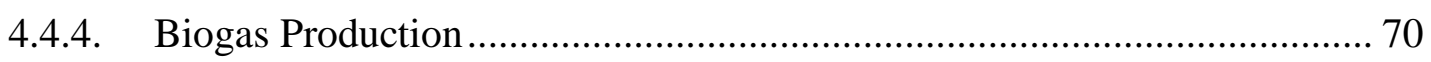

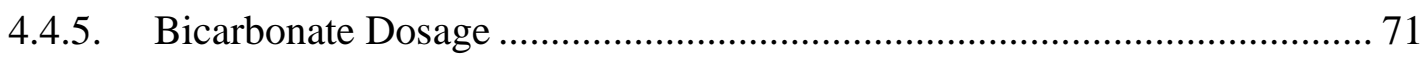

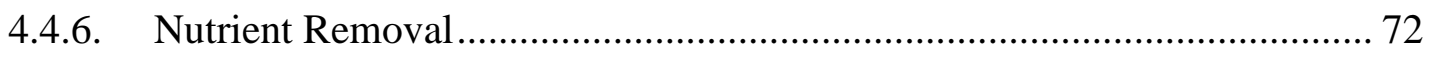

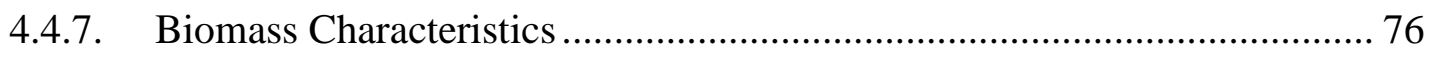

4.4.8. Soluble Microbial Product Characteristics .................................................. 77

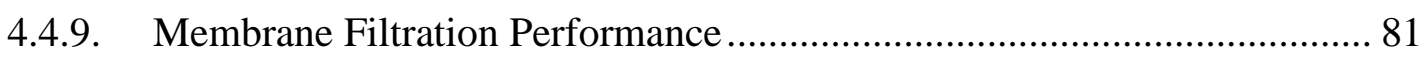

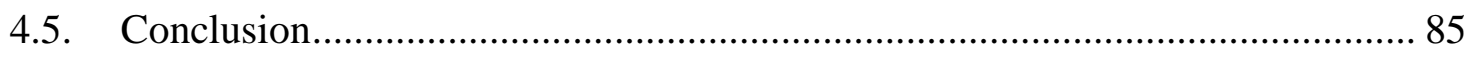

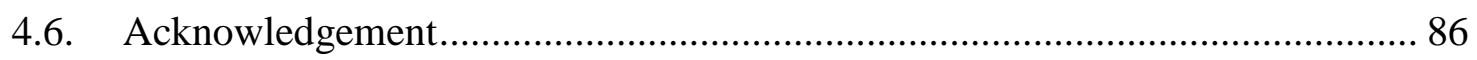

CHAPTER 5 - Conclusion and recommendations ..................................................... 87

5.1. Overall discussion and Conclusion .................................................................. 87

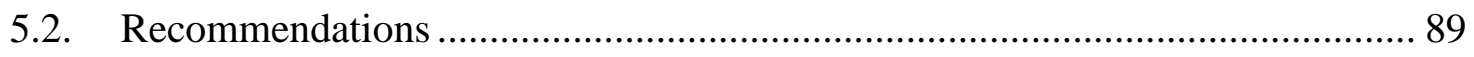

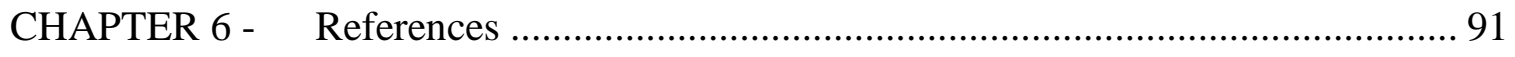

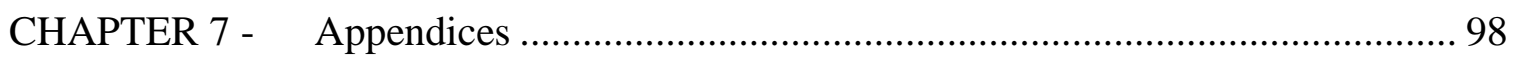

7.1. Appendix I - AnMBR Operation Data ……………......................................... 99

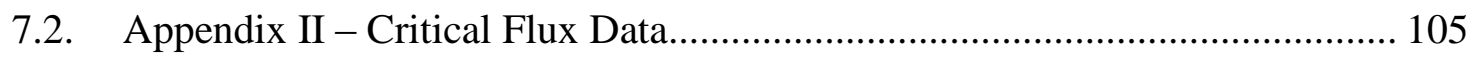




\section{TABLE OF TABLES}

Table 2-1 Main areas of wastewater generation (adopted from (Brewers Association, n.d.))

Table 2-2 Brewery wastewater characteristics ...................................................... 8

Table 2-3 Reported surcharge rates for some Southern Ontario municipalities (Stantec

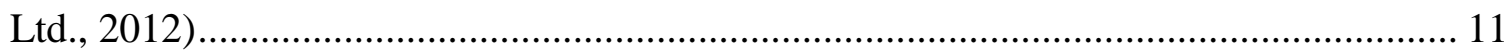

Table 2-4 Comparison of aerobic and anaerobic treatment (Adopted from (Lin et al.,

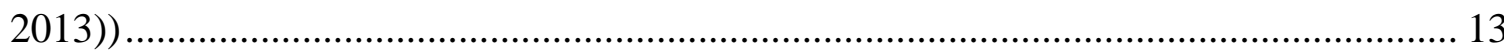

Table 2-5 Summary of lab scale AnMBR configuration and performance for treatment of

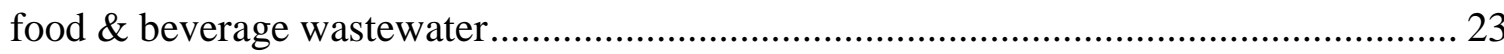

Table 2-6 Summary of pilot and full scale AnMBR configuration and performance for

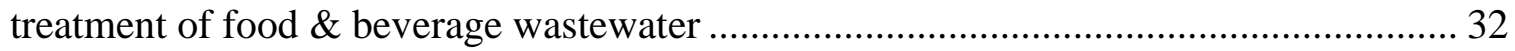

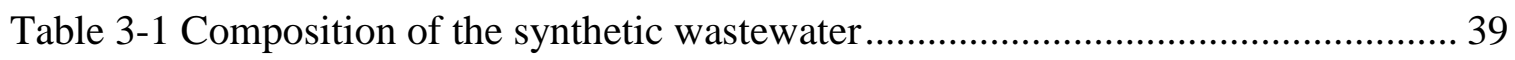

Table 3-2 Characterization of the synthetic brewery wastewater ................................ 40

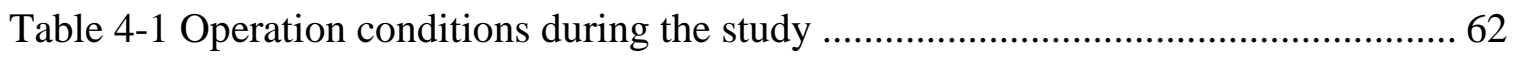

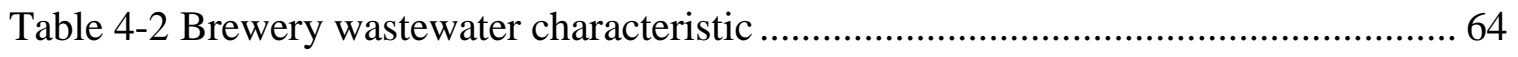




\section{TABLE OF FIGURES}

Figure 2-1 Schematic of AnMBR configurations. (a) External cross-flow AnMBR; (b) Fully submerged AnMBR; (c) Submerged AnMBR with membrane immersed in external tank. 17

Figure 3-1 AnMBR system showing digester (centre) and membrane tank (right) ........ 38

Figure 3-2 Bench scale filtration setup, digester showing in centre ........................... 41

Figure 3-3 COD concentration in the membrane permeate and COD removal efficiency

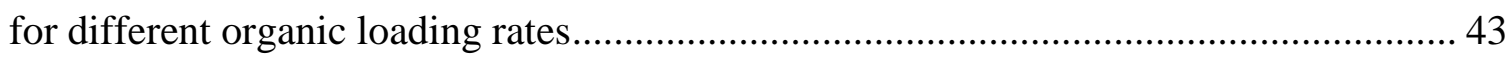

Figure 3-4 COD concentration in the membrane permeate, $1.5 \mu \mathrm{m}$ and $0.45 \mu \mathrm{m}$ filtrate of

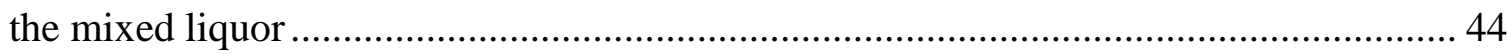

Figure 3-5 Biogas production for different OLR .................................................. 46

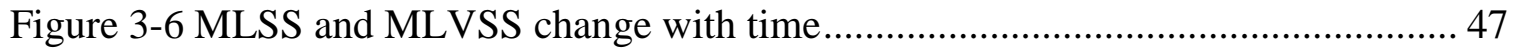

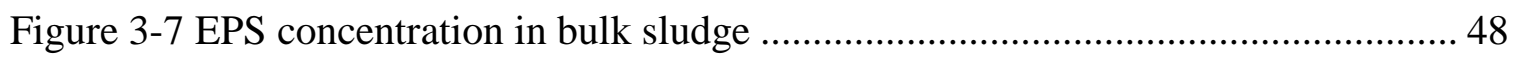

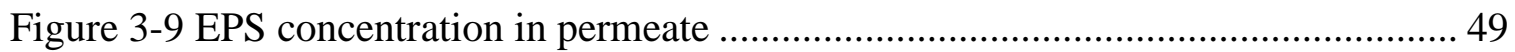

Figure 3-10 Protein and polysaccharide composition in mixed liquor .......................... 50

Figure 3-11 TMP and critical flux change over time........................................... 51

Figure 3-12 Relationship between EPS in bulk sludge and critical flux ...................... 52

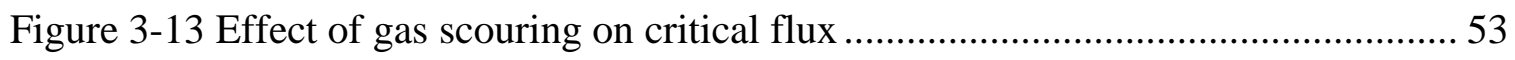

Figure 4-1 AnMBR system showing digester (centre) and membrane tank (right) ......... 60

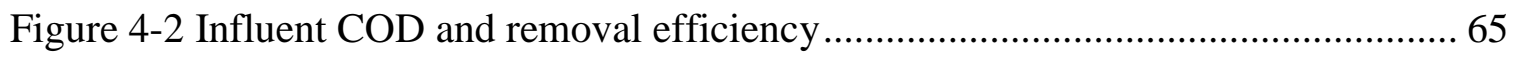

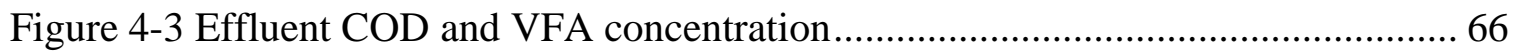

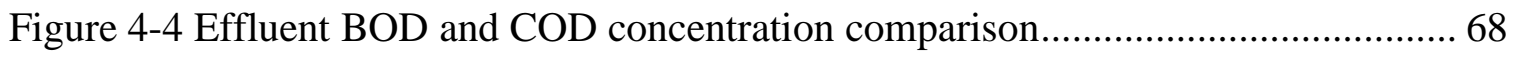

Figure 4-5 COD concentration in the $1.5 \mu \mathrm{m}, 0.45 \mu \mathrm{m}$ filtrate and membrane permeate .. 69 
Figure 4-6 Biogas production under various OLR operation ................................... 70

Figure 4-7 Influent total alkalinity and sodium bicarbonate dosage over the study ........ 71

Figure 4-8 Total nitrogen in feed, permeate and sludge filtrate ................................ 72

Figure 4-9 NH3-N in feed, permeate and sludge filtrate ....................................... 72

Figure 4-10 Total phosphorus in feed, permeate and sludge filtrate ............................ 74

Figure 4-11 Orthophosphate-P in feed, permeate and sludge filtrate ........................... 74

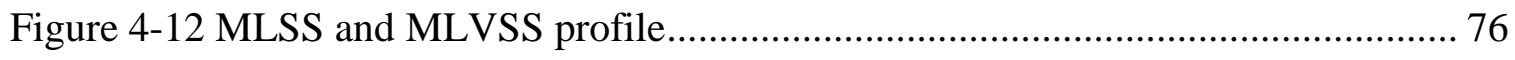

Figure 4-13 Polysaccharide in bulk sludge filtrate and permeate ............................... 78

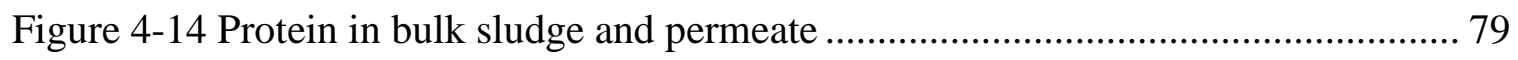

Figure 4-15 Polysaccharide and protein composition in mixed liquor ......................... 80

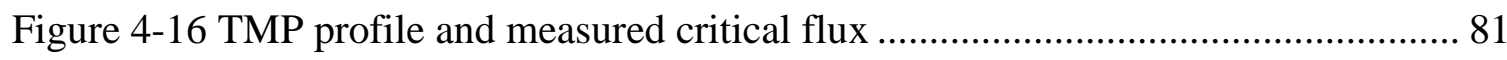

Figure 4-17 Relationship between critical flux and EPS in bulk sludge ...................... 83

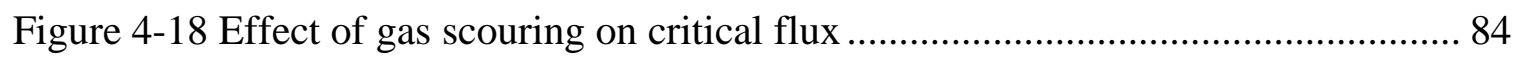




\author{
ABBREVIATIONS \\ AnMBR - Anaerobic Membrane Bioreactor \\ BOD - Biological Oxygen Demand \\ CIP - Cleaning-In-Place \\ COD - Chemical Oxygen Demand \\ CSTR - Continuous Stirred-Tank Reactor \\ TSS - Total Suspended Solid \\ VSS - Volatile Suspended Solid \\ HRT - Hydraulic Retention Time \\ $\mathrm{LMH}-$ Liter $/ \mathrm{m}^{2} /$ Hour \\ MLSS - Mixed Liquor Suspended Solids \\ MLVSS - Mixed Liquor Volatile Suspended Solids \\ MWCO - Molecular Weight Cutoff \\ ODFs - Over strength Discharge Fees \\ OLR - Organic Loading Rate \\ PABR - Periodic Anaerobic Baffled Reactor (PABR) \\ EPS - Extracellular polymeric substances \\ SRT - Solid Retention Time \\ TKN - Total Kjeldahl Nitrogen \\ TMP - Transmembrane Pressure \\ $\mathrm{TN}$ - Total Nitrogen \\ TP - Total Phosphorous \\ UASB - Upflow Anaerobic Sludge Blanket \\ VFA - Volatile Fatty Acids \\ WWTP - Wastewater Treatment Plant
}




\section{CHAPTER 1 - INTRODUCTION}

Over the last decade, the brewery industry structure has changed in Canada. The number of large operation plants has reduced while the number of micro-breweries has considerably increased (Bureau, 2009). With the large growth in the micro-brewery business, municipalities are paying more attention to the environmental issues associated with micro-breweries. Micro-breweries, like any other food and beverage business, must meet the wastewater compliances. Most micro-breweries do not have any dedicated onsite wastewater treatment system; they discharge untreated effluent to a municipal wastewater treatment plant (WWTP). This action results in an expensive wastewater surcharge bill. These surcharges, or over strength discharge fees (ODFs), are in addition to the regulatory sewerage and treatment charges. The surcharges are intended for the municipality to cover the extra cost on WWTP operation for treating the over strength discharges. Paying the bill for continuous high strength wastewater discharging is very costly, which limits the growth of the micro-brewery business. Therefore, many microbreweries are seeking solutions for on-site treatment.

Anaerobic digestion is suitable for treating brewery wastewater, because the effluent from the brewery industry is high in strength and easily biodegradable with a high biological oxygen demand (BOD) to chemical oxygen demand (COD) ratio of 0.6-0.7 (Brito et al., 2007; Rao et al., 2007). Currently, upflow anaerobic sludge bed (UASB) reactors are widely used in the beverage industry. However, they still have a few major drawbacks, including a long start-up period and the requirement of highly skilled operation to prevent biomass loss. Organic loading rates (OLRs) or $\mathrm{pH}$ shocks from the 
batch brewing operations can result in problems such as de-granulation and biomass washout.

Anaerobic membrane bioreactor (AnMBR) represents an advanced technology that has been revitalized by academia and membrane solution providers. With the integration of ultrafiltration (UF) membranes, the AnMBRs can retain all of the biomass and solids. Therefore, it offers a complete separation between solid retention time (SRT) and hydraulic retention time (HRT) as well as a high tolerance to $\mathrm{pH}$ and OLR shocks (Dereli et al., 2012a). The great stability under loading shocks and minimum labour requirement are argued to be the principal benefits compared to the UASB process. Quick start-up times for AnMBRs have been reported generally under 2 weeks (Lin et al., 2013). Although the AnMBR technology is more industrialized in some European countries, it remains in the developing stage in other parts of the world. There are limited pilot or full scale applications reported in available English publications.

There are two configurations used for AnMBRs, including the external cross-flow and the submerged membrane configurations. Most AnMBR studies to date have used an external cross-flow configuration, where it can operate at higher flux while providing direct hydrodynamic control of fouling through cross-flow velocity. However, this arrangement operates at high energy consumption and requires more frequent cleaning (Le-Clech et al., 2006). Further, multiple studies reported that high cross-flow velocity has a negative effect on the biomass activities due to the high shear stress on the microorganisms, and therefore destroys the sludge flocs (Brockmann and Seyfried, 1996; Choo and Lee, 1996). 
Attributable to the submerged MBR concept developed by Dr. Yamamoto (Yamamoto et al., 1989) and the substantial revolutions in the membrane development over the last 20 years (Cote et al., 2012), submerged MBRs are able to operate with manageable energy requirements and pressures up to two orders of magnitude lower than external cross-flow

processes. Advancements in membrane technology have presented great opportunities for the development of more effective AnMBRs. To date, there have been limited submerged AnMBR studies and none have been conducted on brewery wastewater.

Although the excellent COD removal efficiency and biogas generation of AnMBR are well proven, long HRTs and lower OLRs are applied under full scale applications for food processing wastewater (Christian et al., 2010). Several literatures have reported that the high biomass concentration and OLR puts stress on the membrane compartment (Ince et al., 1993; Saddoud and Sayadi, 2007). Low operation fluxes and high gas scouring requirements increase both capital and operation cost. Research on optimizing the OLR and biomass concentration in respect to both digestion and membrane performance would greatly help to shift AnMBR onto industrial-scale applications.

\subsection{OBJECTIVES OF THIS STUDY}

The general goal of this research is to evaluate the efficacy of submerged AnMBR technology in treating wastewater from micro-brewery applications and determine optimum operating conditions for the future commercial implementation. Detailed objectives of this research are: 
a) To demonstrate the efficacy of brewery wastewater treatment using a state-of-theart laboratory scale submerged AnMBR unit, which is equipped with hollow fiber ultrafiltration membranes (GE Water \& Process Technologies).

b) To compare the effect of OLR on AnMBR performance, by evaluating the organic matter removal efficiency, effluent quality, methane yield, biomass growth, soluble microbial product (EPS) generation rate and membrane filterability.

c) To evaluate the effect of biomass concentration in the mixed liquor on EPS generation and membrane fouling.

d) To compare the strength and characteristics of synthetic and real wastewater from a local micro-brewery and assess differences in system performance.

e) To determine the optimal OLR, MLSS and operation flux based on effluent quality and long term membrane performance.

\subsection{RESEARCH APPROACH}

In completing the study, a laboratory scale submerged AnMBR was continuously operated for 230 days. During the first 140 days, synthetic wastewater was appliced to the system with OLR precisely controlled and step increased from $2 \mathrm{~kg} \mathrm{COD} / \mathrm{m}^{3} / \mathrm{day}$ to $10 \mathrm{~kg} \mathrm{COD} / \mathrm{m}^{3} / \mathrm{day}$. The operation was then carried with real brewery wastewater from a local micro-brewery for another 90 days with uncontrolled OLR, which ranged from 3.5 to $11.5 \mathrm{~kg} \mathrm{COD} / \mathrm{m}^{3} /$ day.

Feed, membrane permeate and sludge were sampled weekly and tested for TSS, VSS, COD, TN, TP, $\mathrm{NH}_{4}{ }^{+}-\mathrm{N}, \mathrm{PO}_{4}{ }^{-3}-\mathrm{P}, \mathrm{VFA}$, Tot Alk, polysaccharide and protein. The treatment performance was predominantly evaluated by COD removal. Permeate COD 
was tested every three days under controlled synthetic wastewater operation and was then closely monitored on a daily basis, after being switched with uncontrolled real wastewater. Total alkalinity, $\mathrm{pH}$ and VFA concentration were used as indicators for system stability. Biomass growth and yield were determined by daily MLSS and MLVSS monitoring. Methane yield was calculated from the continuous quantity data and the biogas composition was analysed by gas chromatography. Membrane filtration performance was evaluated through long term transmembrane pressure (TMP) monitoring and weekly critical flux testing.

A bench top bioassay membrane filtration system was built to investigate EPS production and membrane filterability on anaerobic sludge over different biomass concentrations. Short term ( 1 week) constant flux filtrations were conducted within a controlled mesophilic environment. TMP and biogas production were monitored and sludge samples were taken for EPS quantification and prepared for advanced characterization.

\subsection{Thesis ORGANIZATION}

The research findings from this study are presented in manuscript format as two standalone publications. This thesis is organized into seven chapters. The research background and objectives are provided in Chapter 1. Chapter 2 covers the literature review on brewery wastewater characteristics and AnMBR case studies in the food and beverage industry. Chapter 3 and 4 present two related AnMBR studies on the treatment of precisely controlled synthetic wastewater and uncontrolled real brewery wastewater. Each chapter has its own conclusions. Chapter 5 compares and summarizes the two studies. References are listed in Chapter 6 and the Appendix is provided in Chapter 7. 


\section{CHAPTER 2 - ITTERATURE REVIEW}

This section will outline background information and earlier literatures that are fundamental to the thesis. Contents will be organized into three sub-sections. The first section will outline the significance of wastewater treatment in the brewery industry and introduce AnMBR technology, followed by a comprehensive review of the recent AnMBR applications in the food and beverage industry.

\subsection{BREWERY WASTEWATER \& TREATMENT}

The structure of beer sales in Canada has slightly changed in the last few years. Instead of buying from popular brands, consumers are showing preference for craft beer. The number of large beer manufacturing plants has decreased while the number of microbreweries has increased substantially (Bureau, 2009). There are over 47 micro-breweries in Ontario and most of them are facing an excessive amount of wastewater surcharge for discharging high strength wastewater to municipal sewer systems (MEDEI, 2012). Recycling of the regenerated wastewater in the brewery industry is considered inappropriate for production purpose (Braeken et al., 2004). Therefore, many microbreweries are seeking pre-treatment methods to reduce the organic load prior to sewer discharge.

This section will briefly discuss brewery wastewater strength and characteristics, and the driving force behind the sustainable development of micro-breweries in Ontario, as well as the conventional anaerobic treatments and their limitations. Further, this section will introduce the AnMBR technology, which can greatly improve the drawbacks of both conventional and UASB processes. 


\subsubsection{Brewery Wastewater Characteristics}

Beer making involves multiple and complex processes, with major steps include mashing, filtering and boiling wort, as well as fermenting and packaging. Wastewater can be generated in each process by either discharging waste or rinsing equipment. Although each brewery will have different wastewater strength and characteristics related to their operation practices, the U.S. Brewers Association have summarized and published some typical wastewater characteristics from key processes in their Water and Wastewater Sustainability Manual. Table 2-1 shows some major areas of wastewater generation and the approximate wastewater strength. The quantity and quality of the wastewater being generated in each operation varies significantly. Effluent from rinsing fermenters, whirlpools and filters is extremely high in strength but low in volume. However, packaging and cleaning can generate large quantities of effluent containing mostly water and little organic content. 
Table 2-1 Main areas of wastewater generation (adopted from (Brewers Association, n.d.))

\begin{tabular}{|c|c|c|c|}
\hline Source & Operation & Composition & Strength \\
\hline Mash Tun & Rinsing & Cellulose, sugars, amino acids & $\mathrm{BOD} \sim 3000 \mathrm{mg} / \mathrm{L}$ \\
\hline Lauter Tun & Rinsing & Cellulose, sugars, spent grain & BOD 10,000 mg/L, TSS 3000 mg/L \\
\hline Spent Grain & Last run and washing & Cellulose, nitrogenous material & BOD 100,000 mg/L, TSS 30,000 mg/L \\
\hline Boil Kettle & Dewatering & Nitrogenous residue & $\mathrm{BOD} \sim 2000 \mathrm{mg} / \mathrm{L}$ \\
\hline Whirlpool & Rinsing spent hops and hot trub & Proteins, sludge and wort & BOD 85,000 mg/L, TSS 35,000 mg/L \\
\hline Fermenters & Rinsing & Yeast & BOD 100,000 mg/L, TSS 6000 mg/L \\
\hline Storage tanks & Rinsing & Beer, yeast, protein & BOD 80,000 mg/L, TSS $4000 \mathrm{mg} / \mathrm{L}$ \\
\hline Filtration & Cleaning, start up, end of filtration, leaks & Beer, yeast, protein & BOD $\sim 135,000 \mathrm{mg} / \mathrm{L}, \mathrm{TSS} \sim 60,000 \mathrm{mg} / \mathrm{L}$ \\
\hline Beer spills & Waste, flushing & Mostly water, beer & BOD 1000 mg/L \\
\hline $\begin{array}{l}\text { Bottle/keg } \\
\text { washing }\end{array}$ & Discharges & Beer, cleaning chemicals & High BOD and TSS, possibly high pH \\
\hline Miscellaneous & Cleaning and sanitation. Floor washing, etc. & Detergents, cleaning chemicals & Low BOD, TSS, possibly low pH \\
\hline
\end{tabular}

Table 2-2 Brewery wastewater characteristics

\begin{tabular}{|c|c|c|c|c|c|c|c|c|}
\hline Parameters & Survey U.S. & Survey & Opaque & Unicer & Craft & Large plant & China 1 & China 2 \\
\hline $\mathrm{pH}$ & $3-12$ & $4.5-12$ & $4.5 \pm 0.6$ & $6.5-7.9$ & $6.27 \pm 2.45$ & $3-12$ & $6.5 \pm 0.2$ & $7.5 \pm 0.5$ \\
\hline TSS (mg/L) & $200-1500$ & $200-1000$ & $2840 \pm 180$ & & $6300 \pm 2700$ & $2900-3000$ & $480 \pm 70$ & $207 \pm 53$ \\
\hline $\begin{array}{c}\text { COD } \\
(\mathrm{mg} / \mathrm{L})\end{array}$ & $1800-5500$ & $2000-6000$ & $12500 \pm 4300$ & $800-3500$ & $4000 \pm 2100$ & $2000-6000$ & $2250 \pm 420$ & $1585 \pm 170$ \\
\hline $\begin{array}{c}\text { BOD } \\
(\mathrm{mg} / \mathrm{L})\end{array}$ & $600-5000$ & $1200-3600$ & & $520-2300$ & $2800 \pm 1040$ & $1200-3600$ & $1340 \pm 335$ & $710 \pm 150$ \\
\hline BOD/COD & 0.77 & 0.60 & & 0.66 & 0.70 & 0.60 & 0.60 & 0.45 \\
\hline TN (mg/L) & $30-100$ & $25-80$ & $0.023 \pm 0.007$ & $12-31$ & $200 \pm 30^{a}$ & $25-80^{a}$ & $54 \pm 14^{c}$ & $67 \pm 15$ \\
\hline TP (mg/L) & $30-100$ & $10-50$ & $59 \pm 52$ & $9-15$ & $95 \pm 20$ & $10-50^{b}$ & $50 \pm 35$ & $10 \pm 2$ \\
\hline Reference & $\begin{array}{c}\text { (Brewers } \\
\text { Association, n.d.) }\end{array}$ & $\begin{array}{l}\text { (Driessen and } \\
\text { Verejiken, } \\
\text { 2003) }\end{array}$ & $\begin{array}{l}\text { (Parawira et } \\
\text { al., 2005) }\end{array}$ & $\begin{array}{c}\text { (Brito et al., } \\
2007)\end{array}$ & $\begin{array}{c}\text { (Stadlbauer et } \\
\text { al., 1994) }\end{array}$ & $\begin{array}{c}\text { (Rao et al., } \\
2007)\end{array}$ & $\begin{array}{c}\text { (Wang et al., } \\
\text { 2008) }\end{array}$ & $\begin{array}{c}\text { (Zheng et al., } \\
\text { 2014) }\end{array}$ \\
\hline
\end{tabular}

${ }^{\mathrm{a}} \mathrm{TKN},{ }^{\mathrm{b}} \mathrm{PO}_{4}-\mathrm{P},{ }^{\mathrm{c}} \mathrm{NH}_{3}-\mathrm{N}$ 
Wastewater characteristics from two surveys and six case studies are shown in Table 2-2. The qualities of brewery effluents vary significantly among the different breweries. Moreover, in the same brewery, the effluent characteristic can fluctuate significantly as it depends on the different processes that are taking place within the brewery. In general, the brewery wastewater consists of sugar, starch, ethanol and volatile fatty acids (VFAs). The wastewater is slightly acidic and has low suspended solids, high organic matter as well as low nutrient contents. Many studies has reported that the brewery effluents are easily biodegradable with high BOD/COD ratio of 0.6-0.7 (Brito et al., 2007; Rao et al., 2007). Nitrogen and phosphorus levels mainly depend on the amount of yeast present in the effluent (Brito et al., 2007; Driessen and Verejiken, 2003).

Almost all micro-breweries combine wastewater streams together prior to discharge. Depending on the operation, the composition and characteristic of the discharged wastewater fluctuate momentously. While most large breweries have their own wastewater treatment facilities either to meet municipal by-laws or to reduce the organic load (Simate et al., 2011), it is rare to find micro-breweries operate their own pretreatment system. Some micro-plants have preliminary physical operations to remove coarse solid matter rather than dissolved contaminants. These operations include screening and sedimentation, but have yielded little success; the outcome of sedimentation was found unacceptable even with the addition of coagulants (Sheehan and Greenfield, 1980). Due to the high BOD level, almost no raw wastewater from the brewery industry meets sewer discharge standards, which will be discussed in the next section. 


\subsubsection{Wastewater Treatment for Micro-breweries in Ontario}

Beer is composed mostly of water, yet the amount of water used in production is far greater than that within the beer itself. A study to benchmark water usage in the brewery industry was conducted in 2011 by the Beverage Industry Environmental Roundtable (BIER)(Brewers Association, n.d.). There were 211 breweries in the United States that participated in the study. The majority were larger brewers; however, the conclusions can be assumed to be representative for craft breweries. The study reported that in 2010 , the water usage for 1 liter of beer production ranged from 3.26 to 7.44 liters. Conclusions were also drawn regarding the facility size, where larger facilities tend to have lower water use ratio. This was likely due to better management practices in the brewing and packaging processes. There are 47 micro-breweries in Ontario, with approximately $\$ 190$ million sales in 2010, equivalent to a 5\% share of the Ontario beer market, and sales had grown 45\% in 2011 (MEDEI, 2012). With the growth in production, some microbreweries have started to look into environmental issues, especially wastewater management.

The largest driver has been wastewater compliance. Not many micro-breweries have a dedicated on-site wastewater treatment system, whereas most of them discharge untreated effluent to a municipal wastewater treatment plant (WWTP). Although the highly biodegradable wastewater being discharged is generally compatible with the municipal WWTP, it costs the plant more to treat high strength wastewater compared to treating discharge under the by-law limits. Municipalities charge these brewers over strength discharge fees (ODFs) in excess to the regulatory sewerage and treatment custody. These surcharges are usually based on the incoming water quantity, since only a few micro- 
breweries have an effluent discharge metering system installed. The effluent quality is usually tested at the point to discharge by the municipality. The water quality results are then evaluated in according to the Sewer Use By-laws. In Ontario, almost all Sewer Use By-laws were based off the 1998 model provided by the Ministry of the Environment (MOE, 1998). The set discharge limits for major contaminants are 300mg/L for biochemical oxygen demand $\left(\mathrm{BOD}_{5}\right), 350 \mathrm{mg} / \mathrm{L}$ for total suspended solids (TSS), 100 $\mathrm{mg} / \mathrm{L}$ for Total Kjeldahl Nitrogen (TKN) and $10 \mathrm{mg} / \mathrm{L}$ for total phosphorous (TP), respectively. The common ODF structure used in Ontario is based off Water Environment Federation (WEF) Financing and Charges for Wastewater Systems (3rd Edition) (Federation, 2004). Typically, the actual concentrations of the four surchargeable parameters are compared with the Sewers By-law limits. The concentration difference is then used to calculate ODFs as ODF $=($ actual concentration - Sewer By-law limit) * volume * rate and the surcharge of each parameter is addition to another. Surcharge rates for some municipalities in Southern Ontario are listed in Table 2-3, where the rate is with respect to the discharge load in kilograms.

Table 2-3 Reported surcharge rates for some Southern Ontario municipalities (Stantec Ltd., 2012)

\begin{tabular}{ccccc}
\hline Municipality & BOD5 & TSS & TKN & TP \\
\hline Toronto & $\$ 0.62$ & $\$ 0.60$ & $\$ 1.18$ & $\$ 1.69$ \\
York & $\$ 0.53$ & $\$ 0.53$ & $\$ 0.53$ & $\$ 2.65$ \\
Hamilton & $\$ 0.67$ & $\$ 0.53$ & $\$ 2.03$ & $\$ 1.43$ \\
Ottawa & $\$ 1.44$ & $\$ 0.77$ & $\$ 5.75$ & $\$ 2.31$ \\
Durham & $\$ 0.48$ & $\$ 0.48$ & $\$ 0.48$ & $\$ 0.48$ \\
\hline
\end{tabular}

In general, the intention of ODF is to recover the additional costs that are associated with the treatment of high strength wastewater and to upkeep a sustainable operation of the WWTPs (MOE, 1998). However, paying surcharge bills to municipalities for continuous discharging is very costly, especially to the brewery industry, which discharges high 
strength wastewater with an excessive load in $\mathrm{BOD}_{5}$. The surcharge bills often limit the growth of the micro-brewery business. Additionally, due to the development of cities and the capacity of WWTPs, some municipalities may enforce an on-site treatment system in case of expending the existing brewery plant.

In addition to the regulatory surcharges, advertising a wastewater improvement program at craft breweries can positively impact their brand image and public recognition. Since most micro-breweries sell their products locally, having a good image in sustainable development and wastewater management can help with brand recognition and profits.

\subsubsection{Anaerobic Treatment and Limitation of Conventional Methods}

The brewery wastewater is highly biodegradable and has high organic strength; however it has insufficient nutrients for aerobic digestion. This leaves anaerobic treatment as an attractive alternative option. While the aerobic digestion requires intensive aeration and produces more microorganisms, there is no oxygen needed for anaerobic process and the sludge yield is much lower (Liao et al., 2006). These improvements can lower the operation costs dramatically. Furthermore, anaerobic microorganisms convert organic compounds into biogas, which can be utilized directly in a boiler. The biogas usually contains $55-75 \%$ methane and $25-40 \%$ carbon dioxide and traces of hydrogen sulfide (Briggs et al., 2004). A comparison between aerobic and anaerobic treatment on industrial wastewater is shown in Table 2-4. Anaerobic treatment shows an overall advantage over aerobic treatment. However, the widespread application of conventional anaerobic treatment is limited due to the intrinsic low biomass yield of anaerobic bacteria. A long start-up time and large reactor volume is required to provide sufficient solid retention time (SRT) for the methanogens. The large footprint becomes extremely 
challenging as the on-site space arrangement is very crucial. Ince et al. (1993) reported that the OLR can be applied up to $6 \mathrm{COD} / \mathrm{m}^{3} /$ day in a full scale conventional anaerobic digester. Any further increase would be restricted by an insufficient amount of biomass retained in the reactor.

Table 2-4 Comparison of aerobic and anaerobic treatment (Adopted from (Lin et al., 2013))

\begin{tabular}{ccc}
\hline Parameters & Aerobic Treatment & Anaerobic Treatment \\
\hline COD removal efficiency & High & High \\
Effluent quality & High & Moderate \\
Organic loading rate & Moderate & High \\
Sludge production & High & Low \\
Nutrient requirement & High & Low \\
Alkalinity requirement & Low & High (depends on strength) \\
Energy requirement & High & Low \\
Temperature sensitivity & Low & Moderate \\
Start-up time & $2-4$ weeks & 2-4 months \\
Energy recovery & No & Yes \\
\hline
\end{tabular}

With the recognition of the crucial importance of bacterial immobilization, the high rate anaerobic digester was developed in the 1960s and early 1970s. These developments made the anaerobic treatment system feasible and brought public acceptance to anaerobic digestion in wastewater treatment. Two breakthrough developments were the anaerobic filter (AF) system developed in 1964 by McCarty and his co-workers at Stanford University and the upflow anaerobic sludge bed (UASB) reactor by Dr. Lettinga from Agricultual University in Wageningen, 1970 (Lettinga, 2011). Further developments include but are not limited to anaerobic fluidised bed (AFB), expanded granular sludge bed (EGSB) and internal circulation (IC) reactors. Up to date, UASB is still the most widely applied high rate anaerobic treatment process in the food and beverage industry.

In an UASB reactor, the wastewater flows vertically from the bottom, passes upwards through a dense bed of granular sludge and the anaerobic microorganisms degrade the 
substrates as the wastewater come into contact. With the dense packing of granular sludge, the UASB configuration dramatically lowers space requirements and it is capable of treating high organic wastewater at higher hydraulic loads. The UASB technology made it first industrial appearance in the Dutch beet sugar industry (Klijnhout and Eerde, 1986). Through operation with granules at $2-5 \mathrm{~mm}$ in diameter, $60-75 \%$ removal in COD was found. The major limitation in UASB technology is the dependency on the large sludge globules with high settling velocity. It is challenging to have all anaerobic sludge staying in large globule form. Small granules and flocs tend to flush out sooner, causing biomass loss and low quality effluent. The full scale operation on opaque beer brewery wastewater has reported that there is a need to improve UASB performance in terms of organic removal (Parawira et al., 2005). Over a two year study period, a $500 \mathrm{~m}^{3}$ UASB reactor was operated under an average OLR of $6 \mathrm{~kg} \mathrm{COD} / \mathrm{m}^{3} /$ day with influent COD ranged from 8250 to $20000 \mathrm{mg} / \mathrm{L}$ and TSS around $2800 \mathrm{mg} / \mathrm{L}$. The overall COD and TSS removal efficiency were reported as $57 \%$ and $50 \%$ respectively, whereas the digester effluent had a high level of COD ( 2000 mg/L), even under stable operation. The authors argued that the poor performance was mainly due to the presence of suspended solids in the influent and the removal efficiency could be improved base on other lab and pilot UASB studies.

A five month pilot study (Fang et al., 1990) on medium strength (avg. $2700 \mathrm{mg} / \mathrm{L} \mathrm{COD)}$ brewery wastewater showed a better treatment efficiency. At OLR of $4.9 \mathrm{~kg}$ $\mathrm{COD} / \mathrm{m} 3 /$ day, an average of $89 \%$ COD removal was achieved under stable conditions, however great fluctuations were observed following changes in organic loadings. The study indicated that the variability in strength and characteristics of the influent can have 
disturbing effects on UASB performance. Due to changes in operation within the brewery plant, the effluent strength and characteristics fluctuate significantly, making it difficult to retain a constant organic loading rate. Therefore, maintaining a stable operation and consistent discharge quality through UASB treatment processes become challenging.

\subsubsection{Introduction of AnMBR}

While the granular formation represents the traditional high rate anaerobic bioreactor, use of membrane filtration represents an innovative and novel method to operator a bioreactor at high biomass concentration through complete biomass retention. With the use of membrane for liquid solid separation, the AnMBR is capable of completely retaining high concentrations of active biomass, thus minimizing the required reactor volume. Researchers suggested the digester volume can be scaled down to around $1 / 3$ or 1/5 of conventional digesters, with biomass 3 to 5 times as concentrated (Kanai et al., 2010). In addition to delivering effluent free of solid, the membrane barrier also prevents any biomass loss in the effluent under organic load changes and variation in influent characteristics. Because of this, a quick system start-up can be achieved without worrying about granules breakdown or loss of biomass, thus preventing system acidification. Startup times for AnMBRs were reported generally to be under 2 weeks (Lin et al., 2013). The great stability under loading shocks and minimum labour requirements are argued to be the principal benefits of AnMBRs compared to the UASB process. Furthermore, the complete separation of SRT from HRT allows the operator to change the treatment conditions without any adjustment made on the reactor configuration. 
To date, AnMBR systems are based on two main configurations: external cross-flow membrane bioreactors (eAnMBR) and submerged membrane bioreactor (sAnMBR). In the eAnMBR configuration, the membrane modules are placed outside the digester in a cased membrane unit. A high rate pump is used to recirculate the sludge and create a forward driven pressure in the membrane unit, further pushing permeate through the membrane (Figure 2-1a). The external cross-flow configuration can operate at higher flux while providing direct hydrodynamic control of fouling by cross-flow velocity and ease of membrane maintenance. However, this arrangement operates at higher energy consumption and requires more frequent cleaning (Le-Clech et al., 2006). Further, various literatures reported that the high cross-flow velocity has a negative effect on biomass activities due to the high shear stress on the microorganisms, which destroy the sludge flocs (Brockmann and Seyfried, 1996; Choo and Lee, 1996).

Based on the submerged MBR concept developed by Dr. Yamamoto (Yamamoto et al., 1989), the submerged AnMBR (Figure 2-1b) employs membrane directly into the digester and operates under a vacuum pressure while scouring the membrane surface using recirculated biogas. Studies found this configuration operates at a much feasible pressure than the external cross-flow process, which is up to two orders of magnitude lower (Chang et al., 2002). Figure 2-1c shows the modified sAnMBR with membrane immersed in a separate tank, the biomass is being recirculated between the digester and membrane tank. This configuration is often used for full-scale MBR plants due to the ease of membrane cleaning and replacement (Cote and Thompson, 2000). The membrane tank can be easily isolated, instead of physically removing the membrane from a large sealed anaerobic digester, thus ensuring continuous operation during maintenance. 


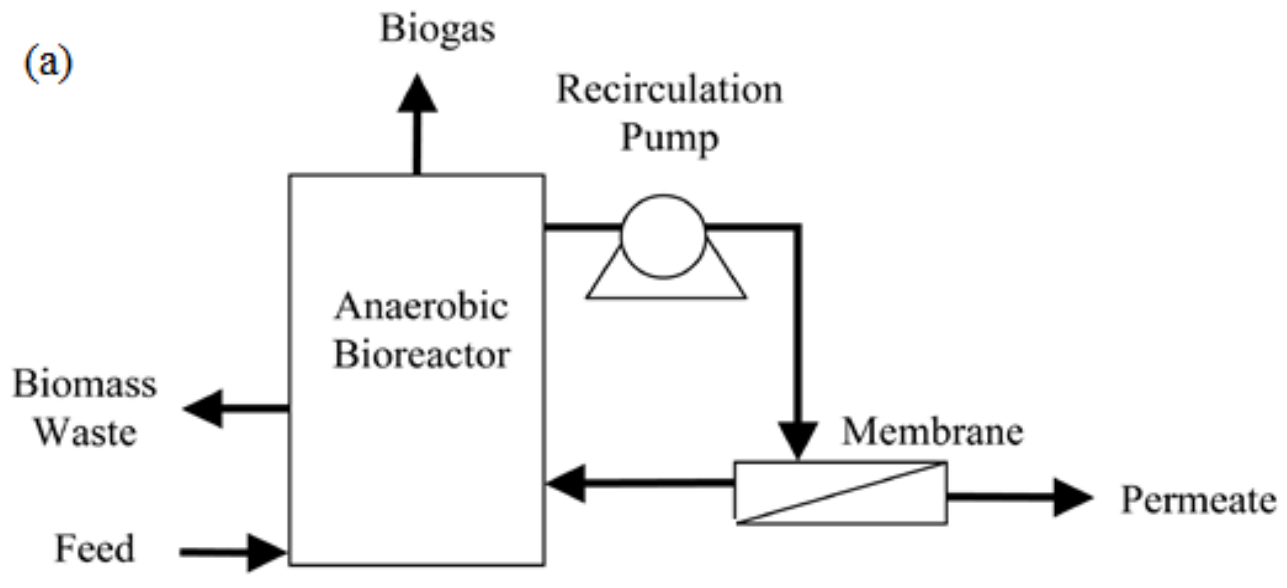

(b)
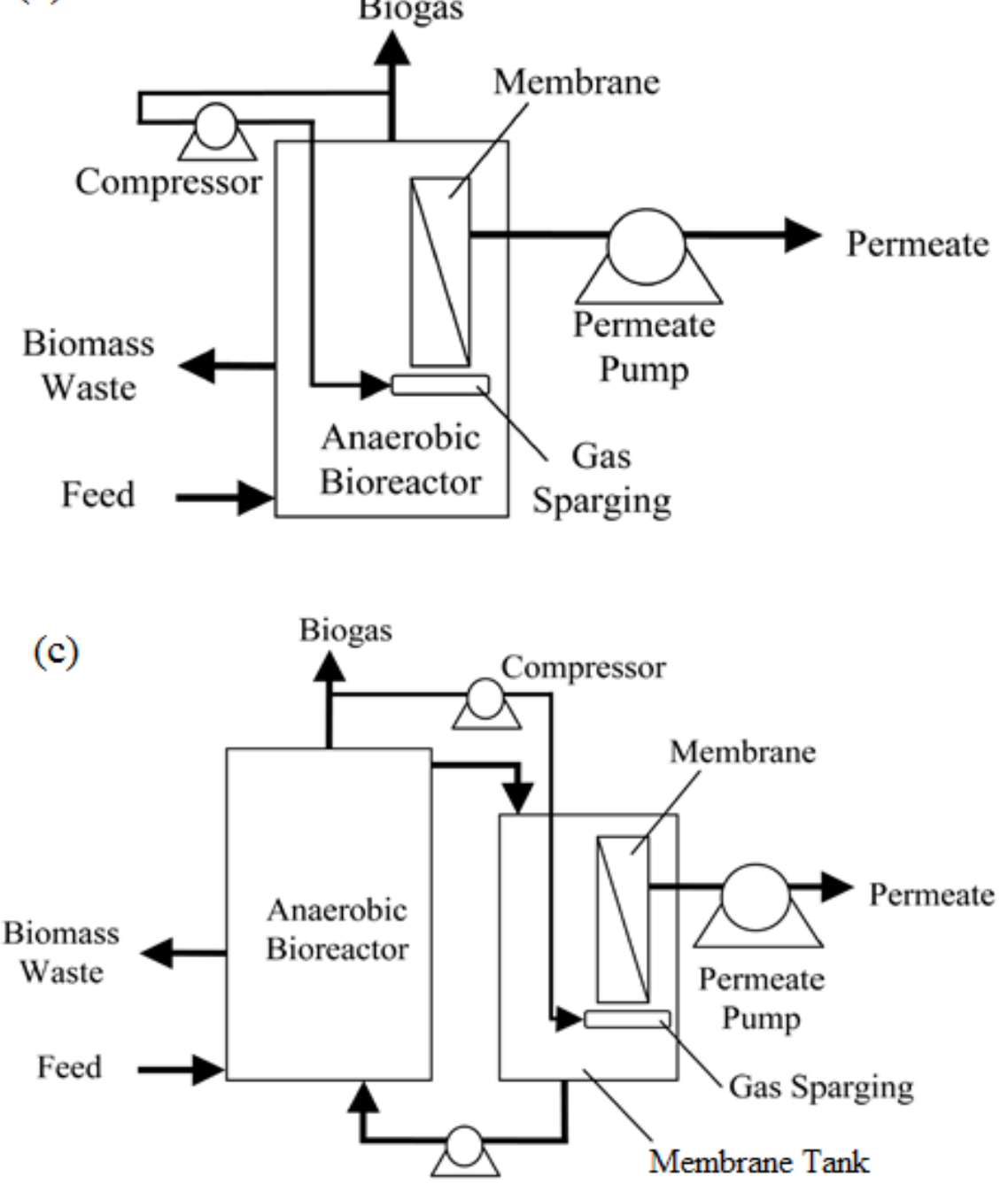

Figure 2-1 Schematic of AnMBR configurations. (a) External cross-flow AnMBR; (b) Fully submerged AnMBR; (c) Submerged AnMBR with membrane immersed in external tank. 
Most membranes used in AnMBR applications are ultrafiltration membranes with pore sizes ranging from 0.03 to $1.0 \mu \mathrm{m}$. The pore openings are significantly lower than the size of most microorganisms and flocs in the mixed liquor; therefore, the membrane retains the biomass completely (Lin et al., 2013). Membranes are manufactured with three major classes of material including polymer, metal and ceramic. Previous AnMBR studies showed that ceramic and metallic membranes have a better hydraulic performance and fouling recovery, as well as a higher resistance to corrosion, abrasion and high temperature (Baker, 2002; Ersu and Ong, 2008; Zhang et al., 2005). However, due to the cost factor alone, the polymeric membranes have dominated commercial applications since economic plays an important role (Santos and Judd, 2010). In the current market, polyvinylidene fluoride (PVDF) and polyethersulfone (PES) membranes account for around $75 \%$ of total production. Owing to the high packing density and cost efficiency, hollow fiber membrane modules are more popular over flat sheet and tubular configurations (Lin et al., 2013). 


\subsection{ANMBR IN THE FOOD AND BEVERAGE INDUSTRY}

Wastewater effluents from the food and beverage industry are characterized by their high organic strength (2000-180,000 mg/L COD) and are readily biodegradable, which is very suitable for anaerobic treatment. In this section, comprehensive reviews of AnMBR case studies in the food and beverage industries are presented. The reviews include the application of AnMBRs in the general food industry since 2000 and all available information on treating brewery wastewater. The source effluents range from field crop processing (potato, olive and palm oil) to food processing (whey, dumpling and snacks), as well as the beverage industry (brewery and distillery). There are 13 lab scale studies and 6 pilots along with two full scale applications presented in this review. In each case study, both reactors and membrane compartments are being reviewed regarding their configuration and performance. The review summaries are divided into two sub-sections: laboratory research and commercial applications.

\subsubsection{AnMBR Developments}

The AnMBR concept was first developed in 1978, where an external cross-flow membrane module was used to treat septic tank effluent (Grethlein, 1978). The trial achieved $85-95 \%$ reduction in BOD, $72 \%$ in nitrate and $24-85 \%$ in orthophosphate removal. However, due to the early stage of membrane development, very high external pressure (345 $\mathrm{kPa}$ to $1030 \mathrm{kPa}$ ) was applied. The filtration flux could be only maintained with high cross-flow velocity and frequent membrane cleaning. The study found the membrane separation method was not feasible to use in rural homes due to its high operation cost and labour attention. The technology was then commercialized by Dorr-

Oliver in the early 1980s, while attempting to treat high strength whey processing 
wastewater (Liao et al., 2006). The pilot system consisted of a continuous stirred-tank anaerobic reactor (CSTR) and an external cross-flow membrane module. Full scale application was not further pursued due to the high membrane cost. Starting in the 1980s, many studies including the significant Aqua Renaissance' 90 project have been conducted on AnMBR technology. Various membrane configurations including materials and module structures were intensively investigated over both suspended and attached film growth anaerobic bioreactors (Liao et al., 2006). With the concept of submerged MBRs was first developed by Professor Yamamoto in 1989, the membrane module was able to operate over a much lower vacuum pressure due to the lower tangential velocity. This configuration reduced the energy requirements potentially up to two orders of magnitude, and further reduced the shear stress on biomass associated with high crossflow velocity (Hai et al., 2013).

Over the past 20 years, there were substantial revolutions in membrane development and manufacturing. Membrane manufactures increased from the two (Zenon and Kubota) in early the 1990s to over dozen today. With the GE Zeeweed membrane alone, there have been new releases introduced every 3-4 years (Cote et al., 2012). Further to the development of cyclic aeration (Cote et al., 2000) and sequential aeration (Breitner, 2013), the air scouring cost has been successfully reduced to a quarter without lowering the filtration performance (Cote et al., 2012). Overall, though the significant increase in flux, packing density and savings in aeration cost, the membrane product today has a volumetric cost of lower than 10\% compared to 15 years ago (Buer and Cumin, 2010). The current commercial submerged hollow fiber membrane cassette can achieve a packing density of $162 \mathrm{~m}^{2} / \mathrm{m}^{3}$. At an average flux of $27 \mathrm{LMH}$, a total permeation capacity 
of $104 \mathrm{~m}^{3} / \mathrm{m}^{3}$ module/day can be achieved (Buer and Cumin, 2010). The continuous revolution in membrane technology has led to rapid development in AnMBRs as well, in both research and commercial applications. Considerable efforts have been made to improve energy efficiency, promoting biogas recovery as well as water reuse. Advancements in membrane technology introduces tremendous opportunity for the development of more effective AnMBRs. 


\subsubsection{Laboratory Research}

By far the most common AnMBR design has been the continuous stirred-tank reactor (CSTR) configuration, due to the ease of construction and operation. In the review of 19 case studies, there are 15 CSTR, 3 UASB (or hybrid) and 1 baffled configuration. The dominance of CSTR is also likely due to the exclusive use of external cross-flow membrane, where the cross-flow velocity is achieved by high mixed liquor recirculation rate, resulting a well-mixed flow regime (Brockmann and Seyfried, 1996; Cote and Thompson, 2000). Further, a shorter start-up period was also observed with the CSTR configuration in comparison to the UASB process (Fuchs et al., 2003).

A summary of 13 lab scale studies are shown in Table 2-5. Most AnMBR studies have used external cross-flow membranes, with the exception of the submerged flat sheet UF membrane that was used during the Kraft evaporator condensate study conducted by Lakehead University (Lin et al., 2009). Early researchers have explained that the high cross-flow velocity usually put high shear stress on the biomass, and on average AnMBRs had a lower microbial activity compared to UASB systems, further restricting the maximum OLRs on AnMBR systems (Brockmann and Seyfried, 1996). In contrast, Yushina and Hasegawa (1994) reported that over a high particulate soybean wastewater

study, the shear stress may promote the breakdown of complex particulates and improved methane yield. Studies on vacuum driven submerged membrane AnMBRs have been limited to date. 
Table 2-5 Summary of lab scale AnMBR configuration and performance for treatment of food \& beverage wastewater

\begin{tabular}{|c|c|c|c|c|c|c|c|c|c|c|c|c|c|c|c|c|}
\hline Source & Reference & $\begin{array}{l}\text { Configu } \\
\text { ration }\end{array}$ & $\begin{array}{c}\text { Membrane } \\
\text { Config. }\end{array}$ & $\begin{array}{c}\text { Membrane } \\
\text { type }\end{array}$ & $\begin{array}{l}\text { Reac } \\
\text { tor } \\
\text { Volu } \\
\text { me } \\
\text { (L) }\end{array}$ & $\begin{array}{c}\mathbf{T} \\
\mathbf{E} \\
\mathbf{M} \\
\mathbf{P} \\
{ }^{\circ} \mathbf{C}\end{array}$ & $\begin{array}{c}\mathbf{H} \\
\mathbf{R} \\
\mathbf{T} \\
(\mathbf{d})\end{array}$ & $\begin{array}{c}\mathbf{S} \\
\mathbf{R} \\
\mathbf{T} \\
(\mathbf{d})\end{array}$ & $\begin{array}{c}\mathbf{O} \\
\mathbf{L} \\
\mathbf{R} \\
(\mathbf{g} / \\
\mathbf{L} \\
/ \mathbf{d})\end{array}$ & $\begin{array}{l}\mathbf{M} \\
\mathbf{L} \\
\mathbf{S} \\
\mathbf{S} \\
(\mathrm{g} / \\
\mathbf{L})\end{array}$ & $\begin{array}{c}\text { Influent } \\
\text { COD } \\
(\mathrm{mg} / \mathrm{L})\end{array}$ & $\begin{array}{c}\text { Efflue } \\
\text { nt } \\
\text { COD } \\
\text { (mg/L } \\
\text { ) }\end{array}$ & $\begin{array}{c}\text { COD } \\
\text { Remo } \\
\text { val } \\
(\%)\end{array}$ & $\begin{array}{c}\text { CH4 } \\
\text { yield } \\
(\mathrm{m3} \\
\mathrm{CH4} \\
/ \mathrm{kg} \\
\mathrm{COD}\end{array}$ & $\begin{array}{l}\text { Flux } \\
(\mathbf{L M} \\
\mathbf{H})\end{array}$ & $\begin{array}{l}\text { TMP } \\
(\mathbf{k P a})\end{array}$ \\
\hline $\begin{array}{c}\text { Alcohol } \\
\text { fermentation }\end{array}$ & $\begin{array}{l}\text { (Kang et } \\
\text { al., 2002) }\end{array}$ & CSTR & External & $\begin{array}{c}\text { Tubular } \\
\text { MF } 0.14 \\
\mu \mathrm{m}\end{array}$ & 5 & 55 & 1 & inf. & $\begin{array}{c}3- \\
3.5\end{array}$ & 2 & 38,400 & & $\begin{array}{l}93- \\
97 \%\end{array}$ & $\begin{array}{c}0.18 \\
7\end{array}$ & $\begin{array}{l}140- \\
180\end{array}$ & 60 \\
\hline Brewery & $\begin{array}{l}\text { (Torres et } \\
\text { al., 2011) }\end{array}$ & CSTR & External & $\begin{array}{l}\text { Ceramic, } \\
0.2 \mu \mathrm{m} \text { and } \\
\text { polyermic } \\
0.03 \mu \mathrm{m}\end{array}$ & 4.5 & 30 & & & 12 & $\begin{array}{l}12- \\
25^{\mathrm{a}}\end{array}$ & 200,000 & 200 & $>97 \%$ & & $4-8$ & \\
\hline Brewery & $\begin{array}{c}\text { (Strohwald } \\
\text { and Ross, } \\
1992)\end{array}$ & CSTR & External & $\begin{array}{c}\text { Tubular UF } \\
\text { PES } \\
\text { MWCO } \\
\text { 40kDa }\end{array}$ & 50 & 35 & $\begin{array}{l}0.5- \\
0.8\end{array}$ & & 15 & $\begin{array}{l}30 \\
50\end{array}$ & $\begin{array}{l}3550- \\
14800\end{array}$ & 180 & $\begin{array}{l}96- \\
99 \%\end{array}$ & & $6-18$ & 180 \\
\hline Brewery & $\begin{array}{c}\text { (Ince et al., } \\
1993)\end{array}$ & CSTR & External & $\begin{array}{c}\text { Tubular UF } \\
\text { Polymer } \\
\text { MWCO } \\
200 \mathrm{kDa}\end{array}$ & 120 & 36 & $\begin{array}{l}2.5- \\
4.2\end{array}$ & inf. & $\begin{array}{c}7.5- \\
28 . \\
5\end{array}$ & $\begin{array}{c}8- \\
50^{a}\end{array}$ & $\begin{array}{l}80,000- \\
90,000\end{array}$ & $\begin{array}{l}200- \\
650\end{array}$ & $97 \%$ & 0.28 & & 240 \\
\hline $\begin{array}{c}\text { Cheese } \\
\text { whey }\end{array}$ & $\begin{array}{l}\text { (Saddoud } \\
\text { and } \\
\text { Sayadi, } \\
\text { 2007) }\end{array}$ & CSTR & External & $\begin{array}{c}\text { Tubular } \\
\text { ceramic, } \\
0.2 \mu \mathrm{m}\end{array}$ & 15 & 37 & $1-4$ & $\begin{array}{l}30- \\
79\end{array}$ & $\begin{array}{l}3- \\
20\end{array}$ & $\begin{array}{c}6.4- \\
10\end{array}$ & $\begin{array}{l}10,000- \\
80,000\end{array}$ & & $98.5 \%$ & 0.3 & 140 & $\begin{array}{l}125- \\
175\end{array}$ \\
\hline $\begin{array}{c}\text { Kraft } \\
\text { evaporator } \\
\text { condensate }\end{array}$ & $\begin{array}{l}\text { (Lin et al., } \\
\text { 2009) }\end{array}$ & $\begin{array}{l}\text { UASB } \\
\text { hybrid }\end{array}$ & Submerged & $\begin{array}{c}\text { Flat sheet } \\
\text { PVDF UF, } \\
\text { MWCO } \\
70 \mathrm{kDa}\end{array}$ & 10 & 55 & 5.8 & 230 & $\begin{array}{c}3.1 \\
\pm \\
0.8\end{array}$ & $\begin{array}{c}8.3 \\
\pm \\
1.6\end{array}$ & $\begin{array}{c}10,000 \\
\pm 500\end{array}$ & $\begin{array}{c}197 \pm \\
54\end{array}$ & $\begin{array}{l}97- \\
99 \%\end{array}$ & $\begin{array}{c}0.35 \\
+ \\
0.05\end{array}$ & $\begin{array}{l}2.4 \\
\pm \\
0.6\end{array}$ & $<30$ \\
\hline $\begin{array}{c}\text { Kraft } \\
\text { evaporator } \\
\text { condensate }\end{array}$ & $\begin{array}{l}\text { (Lin et al., } \\
\text { 2009) }\end{array}$ & $\begin{array}{l}\text { UASB } \\
\text { hybrid }\end{array}$ & Submerged & $\begin{array}{c}\text { Flat sheet, } \\
\text { MWCO } \\
\text { 70kDa }\end{array}$ & 10 & 37 & 1.9 & 230 & $\begin{array}{c}12.2 \\
\pm \\
1.1\end{array}$ & $\begin{array}{c}8.2 \\
\pm \\
1.5\end{array}$ & $\begin{array}{c}10,000 \\
\pm 500\end{array}$ & $\begin{array}{c}151 \pm \\
28\end{array}$ & $\begin{array}{l}97- \\
99 \%\end{array}$ & $\begin{array}{c}0.35 \\
+ \\
0.06\end{array}$ & $\begin{array}{l}7.2 \pm \\
0.9\end{array}$ & $<30$ \\
\hline
\end{tabular}




\begin{tabular}{|c|c|c|c|c|c|c|c|c|c|c|c|c|c|c|c|c|}
\hline Oilve-mill & $\begin{array}{l}\text { (Stamatelat } \\
\text { ou et al., } \\
2009)\end{array}$ & PABR & External & $\begin{array}{c}\text { Tubular } \\
\text { ceramic } \\
\text { UF, } \\
\text { MWCO } \\
25 \mathrm{kDa}\end{array}$ & 15 & 35 & $\begin{array}{c}3.7 \\
5- \\
17 . \\
5\end{array}$ & & $\begin{array}{c}1.5 \\
- \\
8.9\end{array}$ & $\begin{array}{c}12 . \\
8 \\
\text { VS } \\
\text { S }\end{array}$ & $\begin{array}{c}147,000 \\
\pm \\
17000\end{array}$ & & $\begin{array}{l}72- \\
80 \%\end{array}$ & $\begin{array}{c}0.34 \\
6- \\
0.58 \\
0\end{array}$ & $\begin{array}{l}80- \\
450\end{array}$ & 150 \\
\hline Palm oil mill & $\begin{array}{l}\text { (Abdurahm } \\
\text { an et al., } \\
\text { 2011) }\end{array}$ & CSTR & External & $\begin{array}{l}\text { Tubular } \\
\text { UF, } \\
\text { MWCO } \\
\text { 200kDa }\end{array}$ & 50 & & $\begin{array}{l}6.8- \\
600\end{array}$ & $\begin{array}{c}12- \\
100 \\
0\end{array}$ & $\begin{array}{c}1 \\
- \\
11\end{array}$ & $\begin{array}{c}11 . \\
8- \\
20 . \\
8\end{array}$ & $\begin{array}{l}60,000- \\
87,000\end{array}$ & 1400 & $\begin{array}{l}96.6- \\
98.4 \%\end{array}$ & $\begin{array}{l}0.25- \\
0.57\end{array}$ & & $\begin{array}{l}150- \\
200\end{array}$ \\
\hline $\begin{array}{l}\text { Slaughter } \\
\text { house }\end{array}$ & $\begin{array}{l}\text { (Saddoud } \\
\text { et al., } \\
\text { 2007) }\end{array}$ & CSTR & External & $\begin{array}{l}\text { Hollow } \\
\text { fiber UF, } \\
\text { MWCO } \\
100 \mathrm{kDa}\end{array}$ & 50 & 37 & $\begin{array}{l}1.2- \\
3.3\end{array}$ & & $\begin{array}{c}3 \\
- \\
16\end{array}$ & $\begin{array}{l}10 . \\
1^{\text {a }}\end{array}$ & $\begin{array}{c}7150- \\
20,400\end{array}$ & $\begin{array}{l}265- \\
1980\end{array}$ & $>94 \%$ & $\begin{array}{l}0.2- \\
0.31\end{array}$ & 2.22 & 100 \\
\hline $\begin{array}{c}\text { Slaughterho } \\
\text { use }\end{array}$ & $\begin{array}{l}\text { (Siegrist et } \\
\text { al., 2005) }\end{array}$ & CSTR & External & $\begin{array}{l}\text { Ceramic } \\
\text { UF } 0.06 \\
\mu \mathrm{m}, \text { Metal } \\
\text { MF } 3 \mu \mathrm{m}\end{array}$ & 17 & 37 & 35 & $\begin{array}{l}30- \\
40\end{array}$ & $\begin{array}{l}5- \\
17\end{array}$ & & $\begin{array}{c}300,000 \\
- \\
500,000\end{array}$ & & $>90 \%$ & & $\begin{array}{l}40- \\
100\end{array}$ & \\
\hline $\begin{array}{c}\text { Slaughterho } \\
\text { use }\end{array}$ & $\begin{array}{l}\text { (Fuchs et } \\
\text { al., 2003) }\end{array}$ & CSTR & External & $\begin{array}{l}\text { Ceramic } \\
\text { MF } 0.2 \mu \mathrm{m}\end{array}$ & 7 & 30 & 1.2 & & $\begin{array}{l}3- \\
7.4\end{array}$ & $\begin{array}{l}20- \\
28\end{array}$ & $\begin{array}{l}5800- \\
20150\end{array}$ & $\begin{array}{l}100- \\
400\end{array}$ & $>90 \%$ & $\begin{array}{l}0.12- \\
0.32\end{array}$ & $5-10$ & \\
\hline $\begin{array}{c}\text { Tofu } \\
\text { processing }\end{array}$ & $\begin{array}{c}\text { (Kim et al., } \\
\text { 2011) }\end{array}$ & CSTR & External & $\begin{array}{l}\text { Hollow } \\
\text { fiber MF }\end{array}$ & 5 & 60 & & & & $\underset{\mathrm{a}}{5.5}$ & $\begin{array}{l}26,500 \\
\pm 2200\end{array}$ & $\begin{array}{c}<2 \\
\mathrm{~g} / \mathrm{L} \\
\text { carbo }\end{array}$ & & & 4.32 & \\
\hline
\end{tabular}

${ }^{a}$ MLVSS instead of MLSS 
AnMBRs are often operated under mesophilic (35 C) or thermophilic (55 C) conditions. Maintaining the high temperature has not been reported as a challenge for treating high strength food wastewater, where the high quality biogas can be utilized to meet the heating requirement (Liao et al., 2006). Thermophilic conditions allow the system to perform under a higher organic loading (Skouteris et al., 2012). However, a parallel study of two lab scale AnMBRs (Lin et al., 2009) found that the membrane fouling under thermophilic conditions were much more severe than in the mesophilic environment.

Almost all AnMBRs operate in the $\mathrm{pH}$ range of $6.8-7.2$, which refers back to the complicated metabolic pathway of the anaerobic process. The process of hydrolysis and acidogenesis are more robust than acetogenesis and methanogensis. The optimal $\mathrm{pH}$ for methanogens and acid forming microorganisms are slightly different; while the acid forming microorganisms are more favorable to acidic environments, methanogensis favors $\mathrm{pH}$ ranging from 6.8 -7.2. Early research discussed that the activity of methanogens are much lower than the other microorganisms. Therefore, to achieve an overall efficient environment, the AnMBRs usually target to operate at optimal $\mathrm{pH}$ range for methanogens (Rajeshwari et al., 2000). Any disorders in the balance between acid forming and methane forming activity will cause reactor instability. VFA/alkalinity ratio is an important parameter to be monitored during the operation. It is a direct indicator of whether the microorganisms are capable to the organic loading. Usually a peak in VFA concentration is observed after rising to a higher OLR and the new loading operation can be maintained if the VFA concentration returns to lower level. Otherwise, accumulation of VFA in mixed liquor indicates overloading of the system and organic loading should be reduced (Fuchs et al., 2003). 
The HRT of a reactor directly affects the capital cost. A shorter HRT allows for smaller reactor volume and lower initial cost, and often results in a higher OLR and puts the anaerobic system in stress. In general, the HRTs have been reported in AnMBRs have been higher than UASB or other high-rate anaerobic reactors. Reported HRTs are generally in the range of 1 to 35 days depending on the biodegradability and influent solid content. The lowest HRT reported (12 hours) was used for low solid brewery wastewater (Strohwald and Ross, 1992), while in comparison, UASB reactors typically have HRTs of 4-8 hours (Liao et al., 2006).

With the complete retention of biomass, the MLSS concentration in AnMBR is typically much higher than conventional systems. Most laboratory studies demonstrated that MLSS values of 8-25 g/L and $50 \mathrm{~g} / \mathrm{L}$ were achieved for brewery wastewater (Strohwald and Ross, 1992; Torres et al., 2011). However, the performance of anaerobic digestion is not limited to the high biomass concentration. Low MLSS of $2 \mathrm{~g} / \mathrm{L}$ was used in treating complete soluble alcohol fermentation wastewater at around 40,000 mg/L COD (Kang et al., 2002). The authors argued that the microbial cell lysis was enhanced by the high shear induced by high rate recirculation pumping. Though 70 days operation, COD removal was maintained at more than $90 \%$. Yet, a low methane yield at $0.19 \mathrm{~m} 3 \mathrm{CH}_{4} / \mathrm{kg}$ $\mathrm{COD}_{\text {removal }}$ was detected due to the low biomass.

Organic loading rate is a key factor in AnMBR operation and a direct measurement of the system capacity. A wide range of OLRs have been evaluated, aside from the membrane performance, the highest successful OLR was reported at $28.5 \mathrm{~kg} \mathrm{COD} / \mathrm{m}^{3} /$ day for high strength brewery wastewater (Ince et al., 1993). 
A laboratory AnMBR study with slaughterhouse wastewater (Saddoud and Sayadi, 2007) reported a stable operation at OLR under $8.23 \pm 2.6 \mathrm{~kg} \mathrm{tCOD} / \mathrm{m}^{3} /$ day with a COD removal efficiency over 93\%. However, with the increase of OLR, the removal efficiency decreased to $62 \%$ and $53 \%$ at OLR of 13.27 and $16.32 \mathrm{~kg} \mathrm{tCOD} / \mathrm{m}^{3} /$ day, respectively. The poor performance was due to the destabilization of microbial populations from the higher OLR, causing accumulation of VFA, which further acidifies the reactor and therefore inhibits the methanogens activity. VFA concentration greater than $3000 \mathrm{mg} / \mathrm{L}$ was observed over high OLR, thus resulting in a low methane yield at $0.13 \mathrm{~m}^{3} \mathrm{CH}_{4} / \mathrm{kg}$ $\mathrm{sCOD}_{\text {removal }}$. The problem was overcome by the integrated fixed bed reactor (FBR) system to separate the acidogenesis from methanogensis process in the AnMBR. Strohwald and Ross (1992) observed an organic overload after the start-up in a brewery wastewater treatment study. The COD removal dropped to $80 \%$ with a high VFA/Alkalinity ratio of 0.83 . VFA accumulation was also reported in another slaughterhouse wastewater study (Siegrist et al., 2005), however due to the extremely low hydraulic loading (HRT=35 days), no substantial inhibition was observed. Nonetheless, in a similar study performed by Fuchs et al. (2003) at OLR of $7.4 \mathrm{~kg} \mathrm{COD} / \mathrm{m}^{3} /$ day the VFA had increased to over $3000 \mathrm{mg} / \mathrm{L}$. The feeding had to be shutoff for 4 days in order to recover the system. The system was later restarted at a lower OLR of $3.0 \mathrm{~kg}$ $\mathrm{COD} / \mathrm{m}^{3} /$ day and further increased to $4.3 \mathrm{~kg} \mathrm{COD} / \mathrm{m}^{3} /$ day while maintaining stable system performance.

The early AnMBR application on brewery wastewater (Ince et al., 1993) used a cross flow ultrafiltration membrane anaerobic reactor (CUMAR) system treating high strength brewery wastewater with total a COD of 80,000-90,000 mg/L and COD:N:P ratio at 
400:0.7:0.4, which adjusted to 400:5:1 with addition of urea and $\mathrm{KH}_{2} \mathrm{PO}_{4}$. A wide range of OLRs were studied (up to $28.5 \mathrm{~kg} \mathrm{COD} / \mathrm{m}^{3} /$ day) over a 15 month operation period. Biomass in the reactor increased from $5 \mathrm{~g} / \mathrm{L}$ to $50 \mathrm{~g} / \mathrm{L}$ MLVSS. Through no sudden increase in VFA was detected from increasing OLR, the reactor performance was very stable. The study suggested that the biological system did not reach its maximum loading capacity under OLR of $28.5 \mathrm{~kg} \mathrm{COD} / \mathrm{m}^{3} /$ day and $\mathrm{F} / \mathrm{M}$ ratio of $0.55 \mathrm{~kg} \mathrm{COD} / \mathrm{kg} \mathrm{VSS} /$ day, with a COD removal efficiency of $97.3 \%$. Even though the effluent BOD was found to be less than $130 \mathrm{mg} / \mathrm{L}$ at all times, effluent COD was detected over at 200, 440 and 650 $\mathrm{mg} / \mathrm{L}$ at OLR of $7.5,11.5$ and $17.3 \mathrm{~kg} \mathrm{COD} / \mathrm{m}^{3} /$ day, respectively. Although there is a negligible amount of inert soluble COD in brewery wastewater (Ince, 1998), the authors proposed that the soluble inert factions of COD were produced from microbial metabolism and the amount of EPSs may be linked to the microbial population within the MLSS. Methane yield was unchanged at $0.38 \mathrm{CH}_{4} / \mathrm{kg} \mathrm{COD}$ removal up to OLR of $8 \mathrm{~kg}$ $\mathrm{COD} / \mathrm{m}^{3} /$ day; further increases in OLR led to a decrease in both methane composition and methane yield, where $0.28 \mathrm{CH}_{4} / \mathrm{kg} \mathrm{COD}$ removal was reported under $28.5 \mathrm{~kg}$ $\mathrm{COD} / \mathrm{m} 3 /$ day operation. Through an energy balance, the potential corresponding energy recovery on the $120 \mathrm{~L}$ system was $87 \mathrm{MJ} /$ day, which would account for all energy consumptions from the feed pump, mixer and heating. The generated energy provided $70 \%$ of the energy requirement for the high rate recirculation at $108 \mathrm{MJ} / \mathrm{d}$. Constant pressure cross-flow filtration configuration was used in the study. A significant decrease in flux was observed corresponding to an increase of digester biomass concentration. An initial flux of 115 LMH was achieved in the early stage of operation at biomass concentrations as low as $4 \mathrm{~g} / \mathrm{L}$ MLVSS. The flux dropped to $26 \mathrm{LMH}$ in the later stage as the MLVSS 
increased to $50 \mathrm{~g} / \mathrm{L}$. The authors suggested that flux rate is in dependent upon the concentration of biomass.

The most recent brewery wastewater AnMBR study (Torres et al., 2011) used an external cross-flow AnMBR while recirculating a combination of biogas/liquid through the tubular membrane module. The two phase flow regime was generated through the combination of gas injection and cross-flow velocity, creating highly turbulent conditions to control surface cake layer formation. Although the study was successful in the biological component, where over 97\% COD removal was observed under OLR of $12 \mathrm{~kg}$ $\mathrm{COD} / \mathrm{m} 3 /$ day, the two phase flow regime failed to provide high filtration capacity. A low flux at only $4 \mathrm{LMH}$ was obtained over long term operation. The authors concluded that the gas scouring did not provide enough shear stress to prevent single cell deposition over the membrane surface.

A cost analysis based on lab scale studies (Lin et al., 2011) showed that the operational cost of an AnMBR was at only one third of the aerobic treatment process. The energy produced from biogas generation and the membrane gas scouring energy requirement theoretically balances out.

\subsubsection{Commercial Applications}

Compared to laboratory studies of AnMBRs, the numbers of commercial applications have been very limited. From 2000 to date, there are 6 pilot studies and only two industrial applications reported in available literatures (Table 2-6). In contrast to laboratory studies, there are more submerged AnMBRs used in pilot and full scale applications, mainly due to economics, where large savings were generated by 
eliminating the high rate sludge recirculation. In general, most systems removed over $92 \%$ COD; however, longer HRT and lower OLR were used under the pilot and full scale applications. The high MLSS and OLR put stress on the membrane compartment. A low operation flux and high cross-flow velocity and gas scouring intensity would increase both capital and operational cost.

A pilot study conducted on brewery wastewater (Fakhru'l-Razi, 1994) demonstrated that the AnMBR can achieve over 96\% COD removal at high OLR up to $19.7 \mathrm{~kg}$ $\mathrm{COD} / \mathrm{m}^{3} /$ day. The study increased OLR from 12.1 to $19.7 \mathrm{~kg} \mathrm{COD} / \mathrm{m}^{3} /$ day in steps while maintaining MLSS, HRT and decreasing SRT. An increase in VFA concentration (510 to $995 \mathrm{mg} / \mathrm{L}$ ) was observed relative to an OLR increase, and the effluent COD increased at a greater rate (790 to $3100 \mathrm{mg} / \mathrm{L})$. There was no difference in methane yield related to the organic loading change.

In industrial applications, the ratio between the digester and membrane tank is significantly larger than in laboratory setup. The full scale AnMBR at Ken's Food (Massachusetts, USA) processing wastewater consisted of a $8300 \mathrm{~m}^{3}$ anaerobic digester and 4 membrane tanks with working volumes of $100 \mathrm{~m}^{3}$ each, with a high organic strength influent of $475 \mathrm{~m}^{3} /$ day. Over 20 months operation (Christian et al., 2010), the system demonstrated a stable operation under organic loading of $1.2 \mathrm{~kg} \mathrm{COD} / \mathrm{m}^{3} /$ day, achieved COD removal efficiency over 99.4\% and generated consistent effluents at $210 \pm$ $40 \mathrm{mg} / \mathrm{L}$ COD. Due to the high influent solid (12 g/L) and high MLSS concentration (20$45 \mathrm{~g} / \mathrm{L}$ ), the operation flux remained in the range of 2.5 to $4.2 \mathrm{~L} / \mathrm{m}^{2} / \mathrm{hr}$ (LMH). Operating AnMBRs at low flux requires more membrane modules to balance the hydraulic flow, which directly impacts the capital cost of the system. Based on the concept of the critical 
flux, controlling the operation flux is still the most critical strategy to achieve long-term stable operation and therefore extend membrane lifetime. Operation fluxes ranging from 6.7 to $10 \mathrm{LMH}$ were achievable for the treatment of the different wastewaters (Chang, 2014). 
Table 2-6 Summary of pilot and full scale AnMBR configuration and performance for treatment of food \& beverage wastewater

\begin{tabular}{|c|c|c|c|c|c|c|c|c|c|c|c|c|c|c|c|c|}
\hline Source & Reference & $\begin{array}{c}\text { Confi } \\
\text { gurati } \\
\text { on }\end{array}$ & $\begin{array}{l}\text { Membr } \\
\text { ane } \\
\text { Configu } \\
\text { ration }\end{array}$ & $\begin{array}{c}\text { Membrane } \\
\text { type }\end{array}$ & $\begin{array}{c}\text { Reac } \\
\text { tor } \\
\text { Volu } \\
\text { me } \\
\text { (m3) }\end{array}$ & $\begin{array}{l}\text { Temp } \\
\left({ }^{\circ} \mathbf{C}\right)\end{array}$ & $\begin{array}{l}\text { HRT } \\
\text { (d) }\end{array}$ & $\begin{array}{c}\text { SR } \\
\mathbf{T} \\
(\mathbf{d})\end{array}$ & $\begin{array}{c}\text { OLR } \\
(\mathrm{g} / \mathrm{L} / \\
\mathrm{d})\end{array}$ & $\begin{array}{c}\text { MLS } \\
\mathbf{S} \\
(\mathrm{g} / \mathrm{L})\end{array}$ & $\begin{array}{l}\text { Influent } \\
\text { COD } \\
(\mathrm{mg} / \mathrm{L})\end{array}$ & $\begin{array}{c}\text { Efflu } \\
\text { ent } \\
\text { COD } \\
\text { (mg/ } \\
\text { L) }\end{array}$ & $\begin{array}{c}\text { COD } \\
\text { Rem } \\
\text { oval } \\
(\%)\end{array}$ & $\begin{array}{c}\mathrm{CH} 4 \\
\text { yield } \\
\text { (m3 } \\
\mathrm{CH4} \\
/ \mathbf{k g} \\
\mathrm{COD} \\
\text { ) }\end{array}$ & $\begin{array}{c}\text { Flux } \\
(\mathbf{L M} \\
\mathbf{H})\end{array}$ & $\begin{array}{c}\mathbf{T} \\
\mathbf{M} \\
\mathbf{P} \\
(\mathbf{k P} \\
\mathbf{a})\end{array}$ \\
\hline $\begin{array}{l}\text { Animal } \\
\text { waste }\end{array}$ & $\begin{array}{l}\text { (Wong et } \\
\text { al., 2009) }\end{array}$ & CSTR & External & $\begin{array}{c}\text { Tubular PVDF } \\
0.03 \mu \mathrm{m}\end{array}$ & 0.1 & Mes. & 9 & 28 & 2.4 & & $\begin{array}{c}31,800 \pm \\
6560\end{array}$ & $\begin{array}{c}3440 \\
\pm \\
700\end{array}$ & $92 \%$ & & & 200 \\
\hline Brewery & $\begin{array}{c}\text { (Fakhru'l- } \\
\text { Razi, 1994) }\end{array}$ & CSTR & External & $\begin{array}{c}\text { UF MWCO } \\
10 \mathrm{k}\end{array}$ & 0.12 & 35 & $\begin{array}{l}3.64- \\
3.98\end{array}$ & $\begin{array}{l}58- \\
83\end{array}$ & $\begin{array}{l}12- \\
20\end{array}$ & $\begin{array}{l}31- \\
38\end{array}$ & $\begin{array}{l}46,200- \\
84,000\end{array}$ & $\begin{array}{l}790- \\
3100\end{array}$ & $\begin{array}{c}96.3- \\
98.2 \\
\%\end{array}$ & $\begin{array}{c}0.26- \\
0.29\end{array}$ & & $\begin{array}{c}100 \\
- \\
200\end{array}$ \\
\hline $\begin{array}{l}\text { Dumpling } \\
\text { processing }\end{array}$ & $\begin{array}{c}\text { (He et al., } \\
2005)\end{array}$ & CSTR & External & $\begin{array}{c}\text { Flat sheet PES } \\
\text { UF, MWCO: } \\
20-70 \mathrm{kDa}\end{array}$ & 0.4 & 37 & $\begin{array}{l}0.67- \\
4.17\end{array}$ & 50 & $\begin{array}{l}0.88- \\
4.83\end{array}$ & $6-8$ & $\begin{array}{l}2000- \\
15,000\end{array}$ & $\begin{array}{l}141- \\
3600\end{array}$ & $\begin{array}{c}73- \\
94.2 \\
\%\end{array}$ & $\begin{array}{c}0.13 \\
6\end{array}$ & $\begin{array}{c}13.1- \\
18.9\end{array}$ & 200 \\
\hline $\begin{array}{c}\text { Potato } \\
\text { processing }\end{array}$ & $\begin{array}{l}\text { (Singh et } \\
\text { al., 2011) }\end{array}$ & CSTR & $\begin{array}{l}\text { Submer } \\
\text { ged }\end{array}$ & $\begin{array}{c}\text { Flat sheet PET } \\
0.4 \mu \mathrm{m}\end{array}$ & 3.3 & 35 & $\begin{array}{c}3.5- \\
14\end{array}$ & 80 & $2-12$ & 40 & & & $99 \%$ & 0.34 & $\begin{array}{c}0.83 \\
-5\end{array}$ & $3-4$ \\
\hline $\begin{array}{c}\text { Salad } \\
\text { dressing } \\
\text { processing }\end{array}$ & $\begin{array}{l}\text { (Christian } \\
\text { et al., 2010) }\end{array}$ & CSTR & $\begin{array}{l}\text { Submer } \\
\text { ged }\end{array}$ & $\begin{array}{c}\text { Flat sheet PET } \\
0.4 \mu \mathrm{m}\end{array}$ & 8700 & 33 & 29 & & 1.2 & 23 & $\begin{array}{c}33,500 \\
\pm \\
9350\end{array}$ & $\begin{array}{c}209 \\
\pm \\
39\end{array}$ & $\begin{array}{c}99.4 \\
\%\end{array}$ & & $\begin{array}{c}2.5- \\
4.5\end{array}$ & 3 \\
\hline $\begin{array}{l}\text { Shochu } \\
\text { Distilley }\end{array}$ & $\begin{array}{l}\text { (Kanai et } \\
\text { al., 2010) }\end{array}$ & CSTR & $\begin{array}{l}\text { Submer } \\
\text { ged }\end{array}$ & Flat sheet MF & & Therm & & & & & $\begin{array}{l}57,000- \\
182,400\end{array}$ & & $\begin{array}{l}75- \\
92 \%\end{array}$ & & & \\
\hline $\begin{array}{l}\text { Snacks } \\
\text { factory }\end{array}$ & $\begin{array}{c}\text { (Diez et al., } \\
\text { 2012) }\end{array}$ & UASB & $\begin{array}{l}\text { Submer } \\
\text { ged }\end{array}$ & $\begin{array}{l}\text { Hollow fiber } \\
\text { PVDF } 0.4 \mu \mathrm{m}\end{array}$ & 0.76 & 35 & & & 5.1 & $\begin{array}{l}7.9- \\
10.4\end{array}$ & $\begin{array}{l}8200- \\
22,000\end{array}$ & $\begin{array}{l}110- \\
250\end{array}$ & $97 \%$ & & $\begin{array}{c}6.5- \\
8.0\end{array}$ & $\begin{array}{l}18- \\
51\end{array}$ \\
\hline
\end{tabular}


Some industrial application demonstrated successful conversion and utilization of energy from biogas through mass balance. Shochu manufacture in Japan has had an AnMBR treatment facility installed for its distillery wastewater since 2005. A study in 2010 reported that the treatment plant had an average of $12 \mathrm{GJ} /$ day energy recovery from biogas, which is well above the electricity consumption and the membrane bioreactor heating requirement on site (Kanai et al., 2010). However, there was no energy utilization method reported. So far, little information is available regarding AnMBR the energy consumption or energy production, and almost no public research has been made on optimization or modelling. Conducting more research with respect to energy balance would greatly help to shift the AnMBRs onto industrial-scale applications.

Of the 13 laboratory studies and 8 commercial applications of AnMBR in the food and beverage industry were reviewed in this section, most of the applications used external cross-flow filtration configuration and reported high energy consumption. In this research, an advanced submerged AnMBR will be evaluated regarding to biological and membrane performance. 


\section{CHAPTER 3 - SYNTHETIC WASTEWATER}

\subsection{Abstract}

This study investigated the applicability of the anaerobic membrane reactor (AnMBR) technology for the treatment of high organic strength brewery wastewater. The AnMBR was subjected to a stable operation over various organic loading rates (OLRs) of 2, 5, 7.5 and $10 \mathrm{~kg} \mathrm{COD} / \mathrm{m}^{3} /$ day. The system achieved over 99\% COD removal efficiency, excessive methane yield $\left(0.38 \mathrm{~m}^{3} \mathrm{CH}_{4} / \mathrm{kg} \mathrm{COD}\right.$ at $\left.35^{\circ} \mathrm{C}\right)$ and minor membrane fouling. Greater microbial growth rates were observed over a shorter solid retention time (SRT), and more extracellular polymeric substances (EPSs) were released into bulk sludge at a higher organic loading rate, likely due to a higher metabolic rate. Results showed that the ultrafiltration (UF) membrane retained all suspended solids, rejected over $95 \%$ soluble polysaccharides and played an important role in improving the effluent quality. The study also found the EPS in bulk sludge was significantly correlated to membrane fouling when the polysaccharide and protein concentrations were below $200 \mathrm{mg} / \mathrm{L}$ and $800 \mathrm{mg} / \mathrm{L}$. This research confirms the efficacy of using AnMBR with high strength brewery wastewater treatment, achieving high energy recovery while producing excellent quality effluent.

Keywords: Anaerobic membrane bioreactor, brewery wastewater treatment, membrane fouling, organic loading rate, anaerobic digestion, specific growth rate 


\subsection{INTRODUCTION}

The beer brewing industry discharges high organic strength wastewater, which can present challenges for the municipal wastewater treatment plants if being discharged into the sewer system. It can also cause severe environmental impacts if discharged directly into water bodies. Economic and social pressure has been placed on breweries to treat effluent onsite for reuse or prior to discharging. Early research (Ince, 1998) has found that brewery wastewater has a negligible amount of non-biodegradable soluble COD, where it makes the biological treatment feasible.

Anaerobic treatment is a fast growing application, especially for high organic strength industrial wastewater. It offers many advantages over the commonly used aerobic treatment, such as lower sludge production and the ability to withstand high organic load and lower operation cost due to no aeration requirements (Skouteris et al., 2012). More importantly, anaerobic digestion can convert the organic contents in the wastewater into an usable energy source by producing biogas. Van Zyl et al.(2008) reported a $2.02 \mathrm{kWh}$ energy per kg COD removed, about 7 times higher than the amount required for the system operation.

Since anaerobic microorganisms take significantly longer time to grow, immobilizing bacterial sludge for uncoupling the solid retention time (SRT) and hydraulic retention time (HRT) becomes important, which makes conventional systems unfavourable. Currently, there are several types of anaerobic bioreactors to treat brewery wastewater. The upflow anaerobic sludge blanket (UASB) is the most common (Brito et al., 2007). The UASB retains biomass by forming dense granules with high settleability, and the wastewater degrades as it flows vertically upward through the dense bed of granular 
sludge (Rajeshwari et al., 2000). Some drawbacks of UASB include long start-up periods and the requirement of highly skilled operation to prevent biomass loss. The organic loading rate (OLR) or $\mathrm{pH}$ shocks from the batch brewing operations can result in degranulation and washout of the biomass.

Anaerobic membrane bioreactor (AnMBR) is an advanced anaerobic wastewater treatment technology and is lately being revitalized by academia and membrane solution providers. AnMBRs are commonly configured with microfiltration (MF) or ultrafiltration (UF) membranes, which can completely retain solid and biomass, further offer entirely separation between SRT and HRT. This technology offers an attractive option for brewery wastewater treatment, as the shocks in OLR or $\mathrm{pH}$ would no longer cause loss of biomass and upset the system (Dereli et al., 2012a). Earlier research (Ince et al., 2000) showed a successful treatment of synthetic high strength brewery wastewater by a conventional cross-flow ultrafiltration membrane anaerobic reactor (CUMAR). The system operated at a high SRT (70 to 100 days) and had high mixed liquor suspended solids (10-50 g/L MLSS). The researcher reported that the influent COD and operation OLR had a direct impact on the effluent soluble COD, where an average effluent COD of 220, 440 and $660 \mathrm{mg} / \mathrm{L}$ was observed over stable operation under various OLR of 7.5, 11.5 and $17.3 \mathrm{~kg} \mathrm{COD} / \mathrm{m}^{3} /$ day, respectively. The study also found a methane yield of $0.35 \mathrm{~m}^{3} \mathrm{CH}_{4} / \mathrm{kg} \mathrm{COD}$ removed at stable operation, which the potential energy production would enable to maintain approximately $75 \%$ of the CUMAR system operation energy requirements (Ince et al., 2001). However, the major drawback of the external cross-flow type filtration system is a high operational cost of which over $90 \%$ of total operation energy was used for sludge recirculation. 
The success of MBR technologies have resulted in substantial progress within membrane filtration technology for large-scale wastewater treatment applications (Buer \& Cumin, 2010). The advancement in the recent membrane filtration has provided tremendous opportunity for the development of more effective AnMBR systems for high strength wastewater treatment. More recent work by Van Zyl et al. (2008) showed that high strength soluble petrochemical wastewater (18 g COD/l) can be treated effectively (>96\% COD removal) at short retention times (17 h) and high loading rates (up to $25 \mathrm{~kg}$ $\mathrm{COD} / \mathrm{m}^{3} /$ day). Although there is existing research on the application of AnMBRs for other types of wastewater, recent research on AnMBR performance for brewery wastewater treatment is very limited.

This study evaluates the treatment of high strength brewery wastewater by an AnMBR system with the most advanced membrane filtration design. The results include the COD removal efficiency, biogas production rate and the critical flux achieved under different organic loading rates by the AnMBR system. The study will also discuss the biomass growth rate, the extracellular polymeric substances (EPS) production and the role of the membrane filtration in improving effluent quality. These results are significant for understanding the treatment capacity of AnMBRs for brewery wastewater treatment. 


\subsection{MATERIAL AND MethodS}

\subsubsection{AnMBR System}

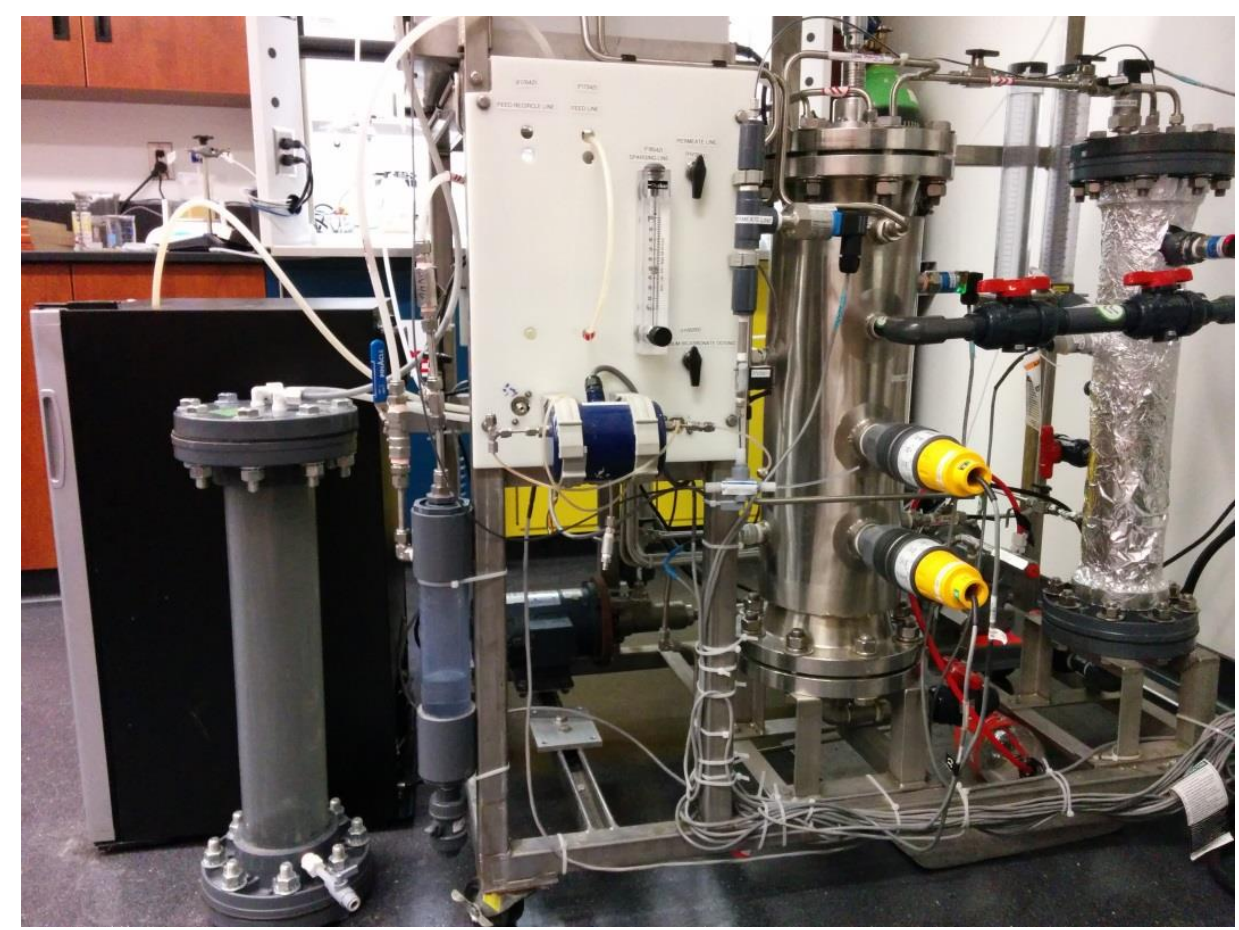

Figure 3-1 AnMBR system showing digester (centre) and membrane tank (right)

As shown in Figure 3-1, the lab-scale AnMBR used in this study consisted of a complete mix anaerobic digester and a membrane tank. Continuous mixing was performed in the anaerobic reactor by using a mechanical mixer (Eurostar, IKA). The mixed liquor was recirculated from the anaerobic reactor to the bottom of the membrane tank and overflowed from the top portion of the membrane tank back to the reactor. A submerged hollow fiber membrane module with a total surface area of $0.047 \mathrm{~m}^{2}$ (GE Water and Process Technologies, Oakville $\mathrm{ON}$ ) was used for liquid-solid separation. A peristaltic pump (Miniplus 3, Gilson) was installed to extract permeate at a constant flux and biogas was recirculated to the membrane tank for membrane scouring. Pressure sensors 
(Cerabar T, Endress Hauser) were installed on the digester tank and permeate line to monitor the system pressure and TMP, respectively. Level sensors were used to control the feed pump to maintain a working volume of $15 \mathrm{~L}$ in the system. The bioreactor temperature was maintained at $15^{\circ} \mathrm{C}$ by recirculating hot water in the water jacket. System $\mathrm{pH}$ was controlled by dosing sodium bicarbonate using a diaphragm metering pump (Stepdos 08, KNF). Biogas production was measured on-line by a mass flow meter (Burkert 8700). A PLC system was used to control the MBR system and for the collection of operation data.

\subsubsection{Wastewater Characteristics}

This study used synthetic brewery wastewater that was supplemented to provide a COD:N:P ratio of approximately 260:4:1 with the macronutrient and micronutrient compositions slightly modified from the ones given in Scampini (2010). Table 3-1 shows the main composition of macronutrients and micronutrients for the synthetic wastewater used at an OLR of $10 \mathrm{~kg} \mathrm{COD} / \mathrm{m}^{3} / \mathrm{day}$, and Table 3-2 shows the corresponding concentration of $\mathrm{COD}$ and nutrients contained in the wastewater.

Table 3-1 Composition of the synthetic wastewater

\begin{tabular}{|c|c|c|c|c|c|}
\hline Macronutrients & Conc. (g/L) & Micronutrients & Conc. (mg/L) & Micronutrients & Conc. (mg/L) \\
\hline Beer $(\mathrm{mL} / \mathrm{L})$ & 27.54 & $\mathrm{FeCl}_{2} * 4 \mathrm{H} 2 \mathrm{O}$ & 11.66 & $\mathrm{AlCl} 3 * 6 \mathrm{H} 2 \mathrm{O}$ & 0.52 \\
\hline $\begin{array}{l}\text { Glacial acetic } \\
\text { acid (mL/L) }\end{array}$ & 11.50 & $\mathrm{MnCl} 2 * 4 \mathrm{H} 2 \mathrm{O}$ & 2.92 & $(\mathrm{NH} 4) 6 \mathrm{Mo} 7 \mathrm{O} 24 * \mathrm{H} 2 \mathrm{O}$ & 0.29 \\
\hline Yeast extract & 1.50 & $\mathrm{CoCl} 2 * 6 \mathrm{H} 2 \mathrm{O}$ & 11.66 & $\mathrm{CuCl} * 2 \mathrm{H} 2 \mathrm{O}$ & 0.22 \\
\hline $\mathrm{NH} 4 \mathrm{Cl}$ & 0.38 & $\mathrm{NiCl} 2 * 6 \mathrm{H} 2 \mathrm{O}$ & 0.83 & $\mathrm{H} 3 \mathrm{BO} 3$ & 0.29 \\
\hline К2HPO4 & 0.24 & $\mathrm{ZnCl} 2$ & 0.29 & $\mathrm{HCl}$ & 0.01 \\
\hline MgSO4 & 0.11 & $\mathrm{Na} 2 \mathrm{SeO} 3$ & 0.72 & EDTA & 5.83 \\
\hline
\end{tabular}


Table 3-2 Characterization of the synthetic brewery wastewater

\begin{tabular}{lrr}
\hline Parameter & Unit & \multicolumn{1}{c}{ Value } \\
\hline COD & $\mathrm{mg} / \mathrm{L}$ & $17,000 \pm 600$ \\
TN & $\mathrm{mg} / \mathrm{L}$ & $268 \pm 18$ \\
$\mathbf{N H}_{4}-\mathbf{N}$ & $\mathrm{mg} / \mathrm{L}$ & $101 \pm 5$ \\
TP & $\mathrm{mg} / \mathrm{L}$ & $66 \pm 2$ \\
$\mathbf{P O}_{4}-\mathbf{P}$ & $\mathrm{mg} / \mathrm{L}$ & $55 \pm 2$ \\
\hline
\end{tabular}

\subsubsection{AnMBR Operation}

The reactor started from an inactive state inherited from a previous study (David Hufnagel, 2014) with an initial MLSS and MLVSS concentration of $2.8 \mathrm{~g} / \mathrm{L}$ and $1.8 \mathrm{~g} / \mathrm{L}$, respectively. The operation periods of the reactor in this study included a start period by batch feeding at an OLR of $2 \mathrm{~kg} \mathrm{COD} / \mathrm{m}^{3} /$ day and continuous feeding operation with OLR at 2, 5, 7.5 and $10 \mathrm{~kg} \mathrm{COD} / \mathrm{m}^{3} /$ day. In order to enhance biomass build up, there was no sludge wasting under OLR of 2,5 and $7.5 \mathrm{~kg} \mathrm{COD} / \mathrm{m}^{3} /$ day operation periods. For the OLR of $\mathrm{kg} \mathrm{COD} / \mathrm{m}^{3} /$ day operation period, there was no sludge wasting in the first 16 days, followed by an average of $500 \mathrm{ml} /$ day sludge wasting, in order to stabilize the MLSS concentration at $11 \pm 1 \mathrm{~g} / \mathrm{L}$, corresponding to a SRT around 30 days. The AnMBR was operated at $\mathrm{pH}$ ranges from 6.8 to 7.3 and temperature of $35 \pm 1{ }^{\circ} \mathrm{C}$. An online alkalinity dosing system was used to maintain the desired $\mathrm{pH}$ condition and the total alkalinity in the mixed liquor during the operation period. Membrane operation flux was set at 8 liter $/ \mathrm{m}^{2} /$ hour $(\mathrm{LMH})$ and the operation cycle involved 10 minute permeation and 1 min relaxation during the entire study. Maintenance cleaning using $2000 \mathrm{mg} / \mathrm{L}$ citric acid and $2000 \mathrm{mg} / \mathrm{L}$ sodium hypochlorite was implemented only after constant SRT operation at OLR $10 \mathrm{~kg} / \mathrm{m}^{3} / \mathrm{day}$. The maintenance cleaning operation involved a 15 minute backwash cycle at permeation flux with each cleaning reagent. 


\subsubsection{Bench Scale Filtration System}

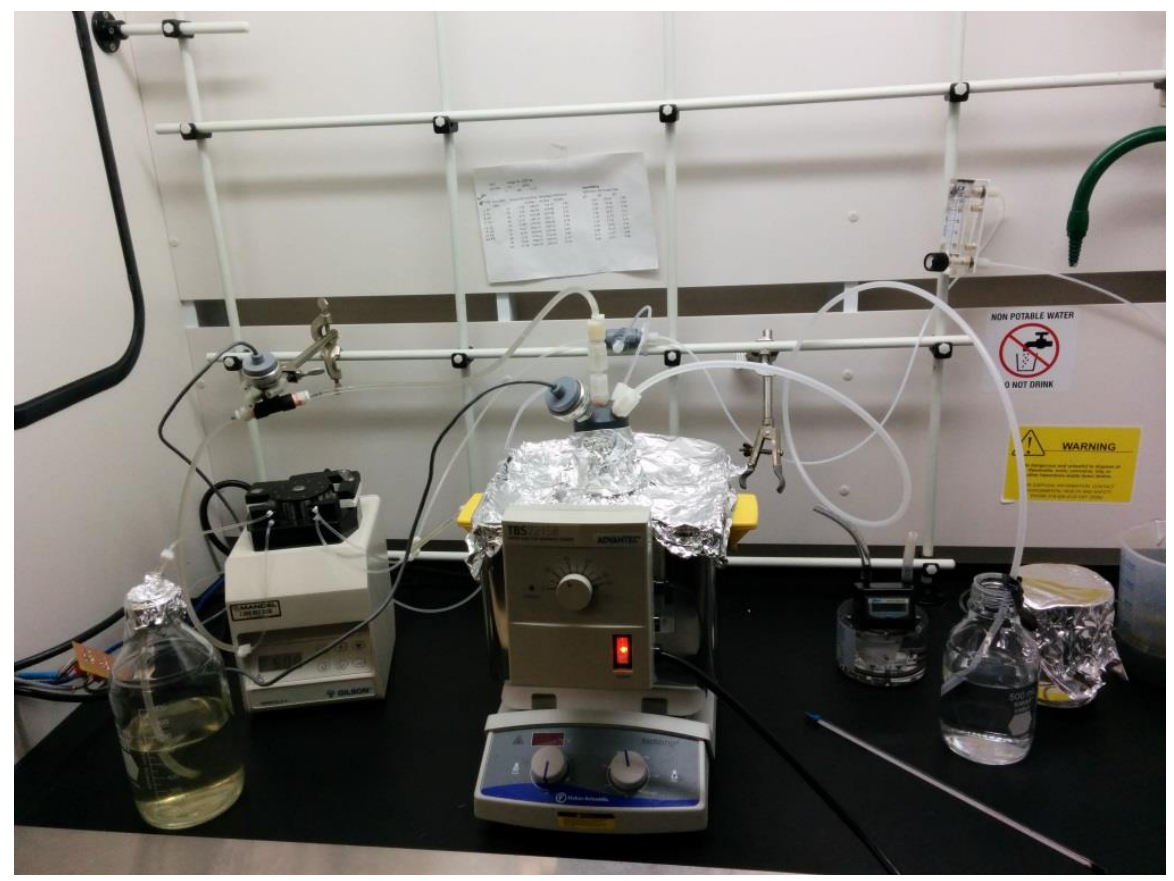

Figure 3-2 Bench scale filtration setup, digester showing in centre

Bench top bioassay membrane filtrations were performed to investigate the EPS

production and membrane filterability over anaerobic sludge with the different biomass concentration. The system (shown in Figure 3-2) consisted of a cylindrical heated vessel (1 L effective volume), a magnetic stir (350 rpm, Isotemp, Fisher Scientific) and a loop shaped hollow fiber membrane module (effective filtration area $=0.00179 \mathrm{~m}^{2}$, GE Water). Anaerobic sludge were taken from the AnMBR and the concentration were adjusted to 10, 15, $20 \mathrm{~g} / \mathrm{L}$ MLSS prior to each filtration test. Each filtration test was operated continuously for 7 days with 3 stages constant flux filtration at 10, 11.5, $13 \mathrm{LMH}$ and other operation conditions were the same as AnMBR. Pressure sensors (Cole-Parmer) were installed on the digester tank and permeate line to monitor the system pressure and TMP, respectively. Biogas productions were monitored with a volumetric gas meter 
(MilliGascounter MGC-1, Ritter). Clean water tests were performed before and after the filtration experiments. The fouling resistance $\left(\mathrm{R}_{\mathrm{f}}\right)$ were calculated as following:

$$
R_{f}=R_{t}-R_{m}=\frac{\Delta P_{t}}{\mu * J(t)}-\frac{\Delta P_{m}}{\mu * J(t)}
$$

Where Rt is the total membrane resistance $\left(\mathrm{m}^{-1}\right)$ from the post filtration clean water test, $\mathrm{Rm}$ is the intrinsic membrane resistance $\left(\mathrm{m}^{-1}\right), \Delta \mathrm{P}$ the TMP $(\mathrm{Pa}), \mu$ the viscosity of water at $35^{\circ} \mathrm{C}\left(\mathrm{Pa}^{*} \mathrm{~s}\right)$ and $\mathrm{J}$ is the permeate flux $\left(\mathrm{m}^{3} / \mathrm{m}^{2} / \mathrm{h}\right)$. All membranes were soaked in deionized water before the test and washed with deionized water after each filtration experiment to ensure surface cake layer was removed. Sludge samples were taken for EPS characterization.

\subsubsection{Analytical Methods}

Membrane permeate samples as well as the sludge samples from the digester and membrane tank were taken regularly for analysis. The supernatant of the mixed liquor was obtained using the centrifugation/filtration procedure with centrifugation at $8000 \mathrm{rpm}$ for $15 \mathrm{~min}$ at $4{ }^{\circ} \mathrm{C}$ followed by filtration through a $1.5 \mu \mathrm{m}$ filter paper. Soluble samples were further filtered through $0.45 \mu \mathrm{m}$ disposable membrane filters.

The Standard Methods (APHA-AWWA-WEF, 2005) were used for the measurements of MLSS and MLVSS concentration. Other parameters including COD, total nitrogen (TN), total phosphours (TP), ammonia nitrogen $\left(\mathrm{NH}_{4}{ }^{+}-\mathrm{N}\right)$, nitrate nitrogen $\left(\mathrm{NO}_{3}-\mathrm{N}\right)$, nitrite nitrogen $\left(\mathrm{NO}_{2} \mathrm{~N}\right)$, phosphate phosphorus $\left(\mathrm{PO}_{4}{ }^{-3}-\mathrm{P}\right)$, and volatile fatty acids (VFA) were measured using Hach methods (HACH, 2008). Protein and polysaccharides concentration of EPSs were determined with the Bradford method (Bradford, 1976) and 
the phenol-sulphuric acid method (DuBois et al., 1956), respectively. Bovine serum albumin (BSA) and glucose were used as standard references and the absorbance was taken by a spectrophotometer (DR5000, Hach). Total alkalinity was measured using an automatic titrator (TitraLab 870, Radiometer analytical). Biogas composition $\left(\mathrm{N}_{2}, \mathrm{CH}_{4}\right.$ and $\mathrm{CO}_{2}$ ) was analysed using gas chromatograph (6890n, Agilent Technologies).

\subsection{RESUlT AND DisCUSSION}

\subsubsection{System Performance}

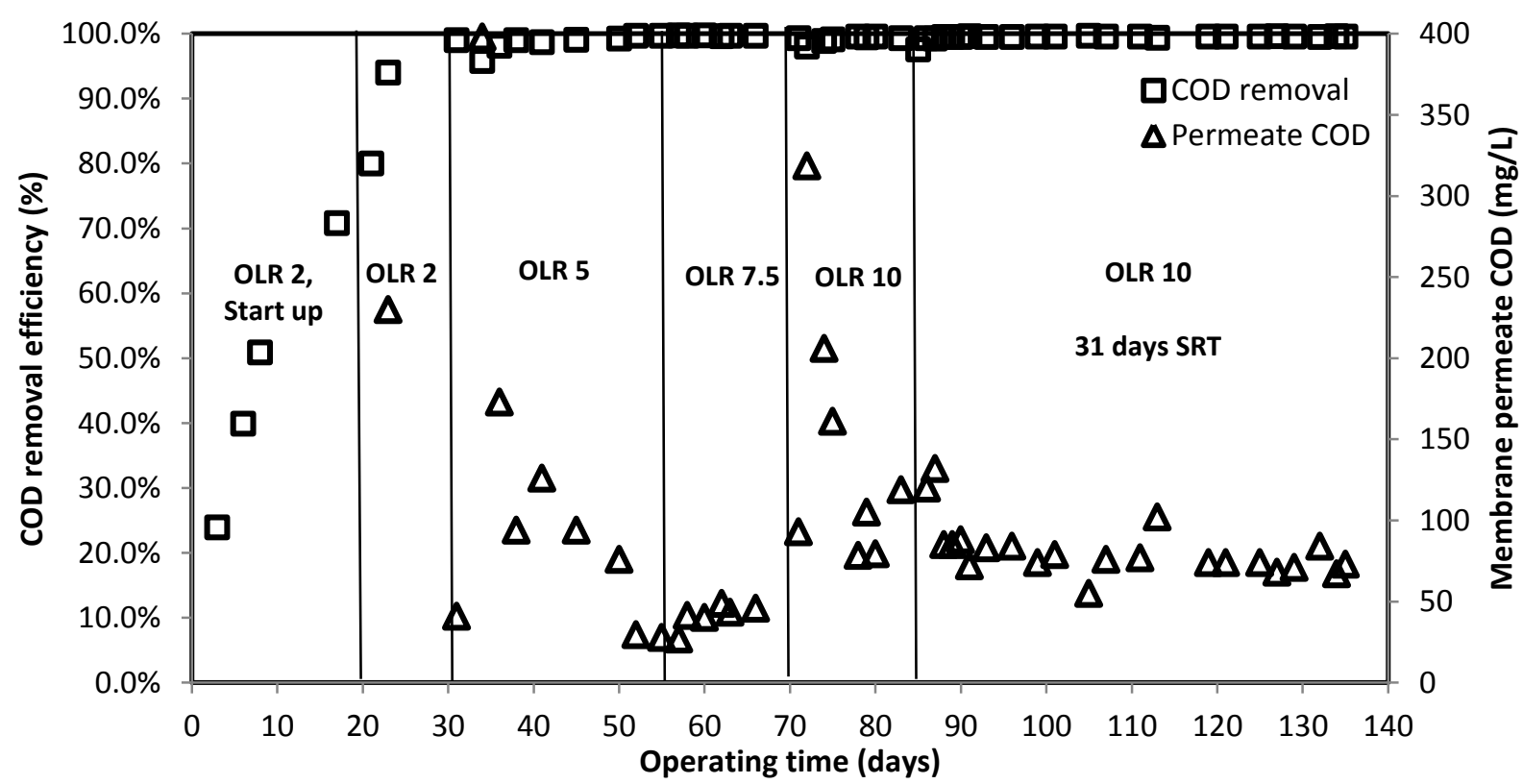

Figure 3-3 COD concentration in the membrane permeate and COD removal efficiency for different organic loading rates

Figure 3-3 shows the COD concentration in the membrane permeate and the COD removal efficiency during the 140 days operation period. The reactor started from an inactive state with batch feeding at OLR $2 \mathrm{~kg} \mathrm{COD} / \mathrm{m}^{3} /$ day. During the start-up period, the soluble COD removal increased from $20 \%$ to $80 \%$ in 20 days, indicating a quick recovery from the inactive state. After the start-up, the reactor operation was then 
switched to continuous feeding and upon day 140, it had gone through operation with different OLRs of 2, 5, 7.5 and $10 \mathrm{~kg} \mathrm{COD} / \mathrm{m}^{3} /$ day. Whenever OLR was increased, a stable operation in terms of the COD concentration in the membrane permeate was reached in 2-8 days and persisted lower than $100 \mathrm{mg} / \mathrm{L}$, which delivered an over $99 \%$ COD removal efficiency. These results indicated that the AnMBR has excellent ability to achieve a quick start-up and high tolerance to the change in organic strength of the wastewater. This is likely due to the complete retention of the active biomass by the membrane and independence of the sludge retention. (Skouteris et al., 2012).

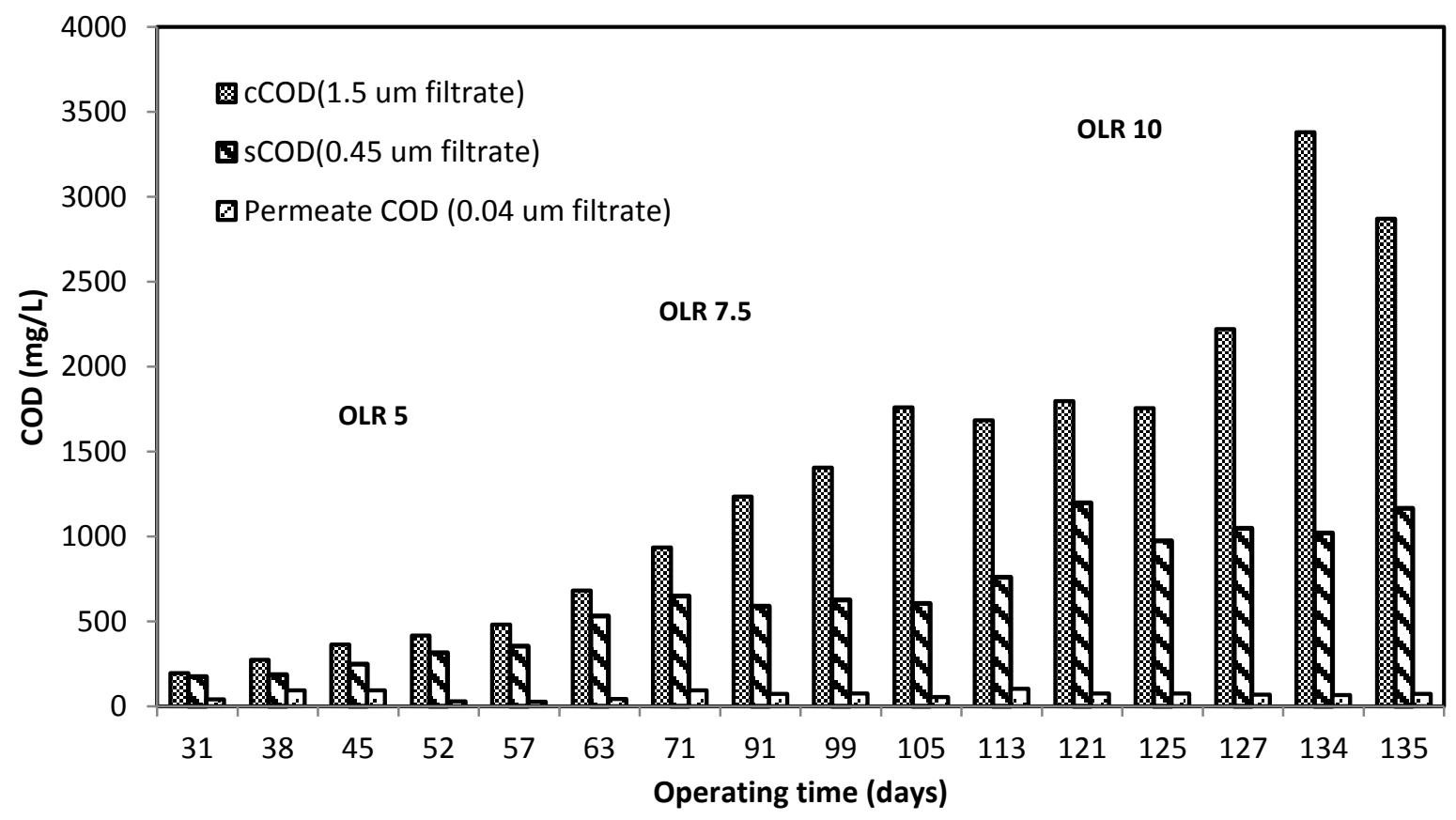

Figure 3-4 COD concentration in the membrane permeate, $1.5 \mu \mathrm{m}$ and $0.45 \mu \mathrm{m}$ filtrate of the mixed liquor The results obtained in this study showed that the membrane filtration played an important role in improving the treatment performance. As showed in Figure 3-4, significant difference was observed from the COD concentration in $1.5 \mu \mathrm{m}$ sludge filtrate, $0.45 \mu \mathrm{m}$ soluble filtrate and $0.04 \mu \mathrm{m}$ ultrafiltration permeate, where the COD in permeate 
was found to be significantly lower $(<100 \mathrm{mg} / \mathrm{L})$. In addition, while the COD concentration of the permeate maintained low and stable for all the organic loading rates tested, the COD concentration in the $1.5 \mu \mathrm{m}$ and $0.45 \mu \mathrm{m}$ filtrate of the mixed liquor increased with the organic loading rate. These results suggested that the membrane filtration played an important role in improving the effluent quality of anaerobic digestion.

The effluent $\mathrm{pH}, \mathrm{VFA}$ concentration and total alkalinity were found to be in favorable conditions for methanogenesis. During the OLR of 2,5 and $7.5 \mathrm{~kg} / \mathrm{m}^{3} /$ day operation, a daily average of $30.0 \pm 2.2 \mathrm{~g} \mathrm{NaHCO}_{3}$ was dosed using an online chemical dosing system, $\mathrm{pH}$ was maintained at $6.85 \pm 0.01$ and the total alkalinity in the mixed liquor was maintained at $2500 \pm 150 \mathrm{mg} / \mathrm{L}$ as $\mathrm{CaCO}_{3}$. At OLR of $10 \mathrm{~kg} / \mathrm{m}^{3} / \mathrm{day}$, a dosage of $26.7 \mathrm{~g}$ $\mathrm{NaOH} / \mathrm{day}$ was used to maintain $\mathrm{pH}$ and total alkalinity at $7.24 \pm 0.01$ and $4500 \pm 300$ $\mathrm{mg} / \mathrm{L}$, respectively. The observed VFA concentrations were lower than $50 \mathrm{mg} / \mathrm{L}$ at alltime, the low VFA/alkalinity ratio $(<0.02)$ ensures an active metabolism of the methanogens. 


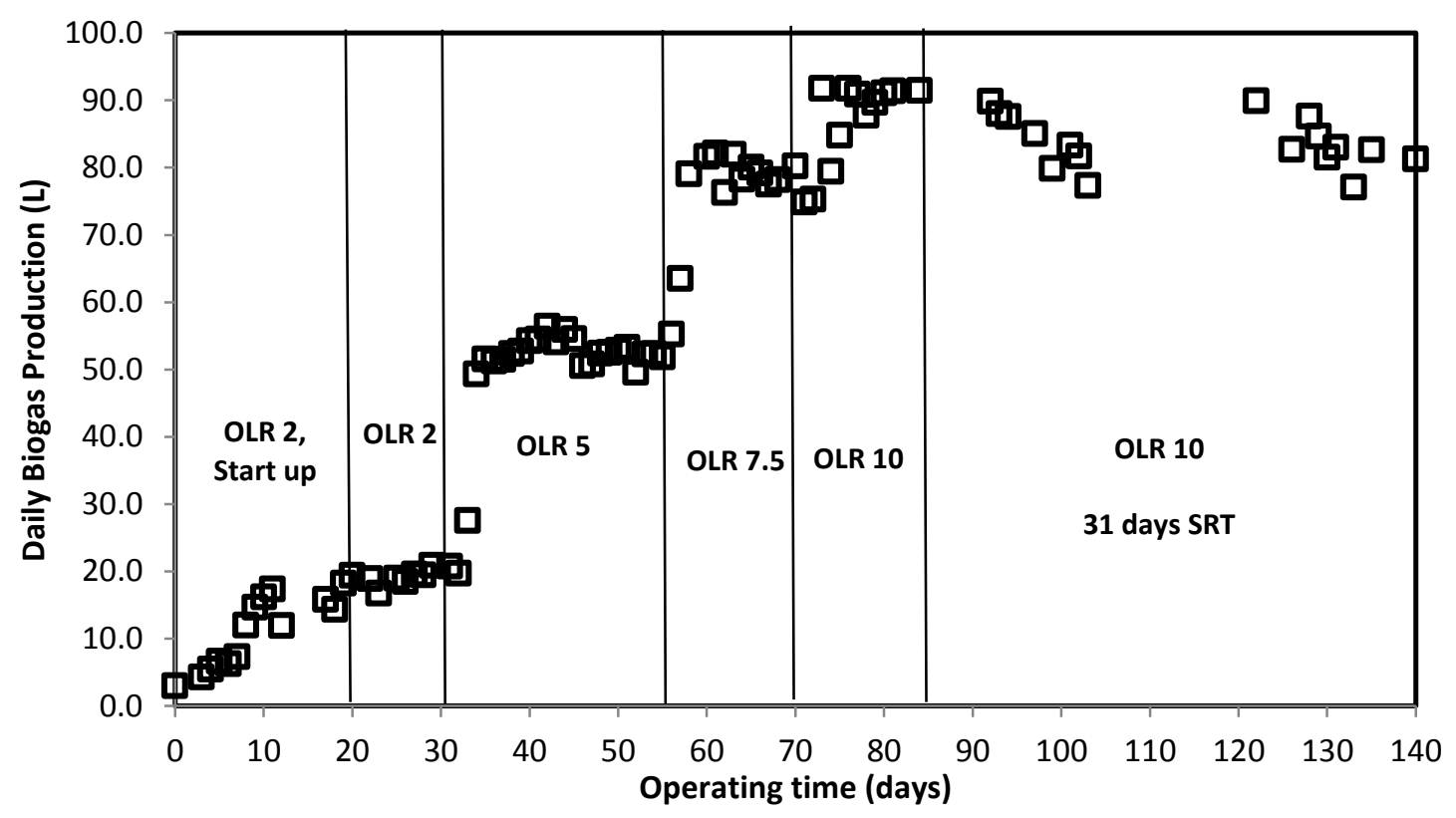

Figure 3-5 Biogas production for different OLR

The biogas production rate was very stable under continuous feeding operation (Figure $3-5)$, with production rate of $18 \pm 1,52 \pm 2,79 \pm 3$ and $86 \pm 4$ L/day for OLRs of 2, 5, 7.5 and $10 \mathrm{~kg} \mathrm{COD} / \mathrm{m}^{3} /$ day, respectively. The methane content in the biogas was determined as $54 \%$ by GC analysis, corresponding to an average methane yield of $0.38 \mathrm{~m}^{3} \mathrm{CH}_{4} / \mathrm{kg}$ COD removed $\left(35^{0} \mathrm{C}\right)$, which represented $96 \%$ of the maximum theoretical value at 0.395 $\mathrm{m}^{3} \mathrm{CH}_{4} / \mathrm{kg} \mathrm{COD}$ removed $\left(35^{0} \mathrm{C}\right)$. The performance indicated the efficacy of energy recovery by AnMBR technology.

\subsubsection{Biomass Characteristics}

Figure 3-6 shows the MLSS and MLVSS concentration during different operation periods. As shown in the figure, the MLSS concentration rapidly increased from around $2.8 \mathrm{~g} / \mathrm{L}$ to $5 \mathrm{~g} / \mathrm{L}$ in the first 10 days during the start-up and was then persisted relatively steadily through the $2 \mathrm{~kg} / \mathrm{m}^{3} /$ day operation period even without sludge wasting. The biomass concentration started increasing rapidly after the organic loading was increased 
from 2 to $5 \mathrm{~kg} / \mathrm{m}^{3} /$ day and maintained a steady MLSS and MLVSS growth rate until the OLR of $10 \mathrm{~kg} / \mathrm{m}^{3} /$ day operation. The MLSS concentration in the reactor was increased up to $16.8 \mathrm{~g} / \mathrm{L}$ on day 80 . Thus, the MLSS concentration in the reactor was reduced to 10 $\mathrm{g} / \mathrm{L}$ by one time sludge wasting and a daily sludge wasting protocol (SRT $=31$ days) was implemented to stabilize the MLSS concentration in the reactor around $11 \pm 1 \mathrm{~g} / \mathrm{L}$.

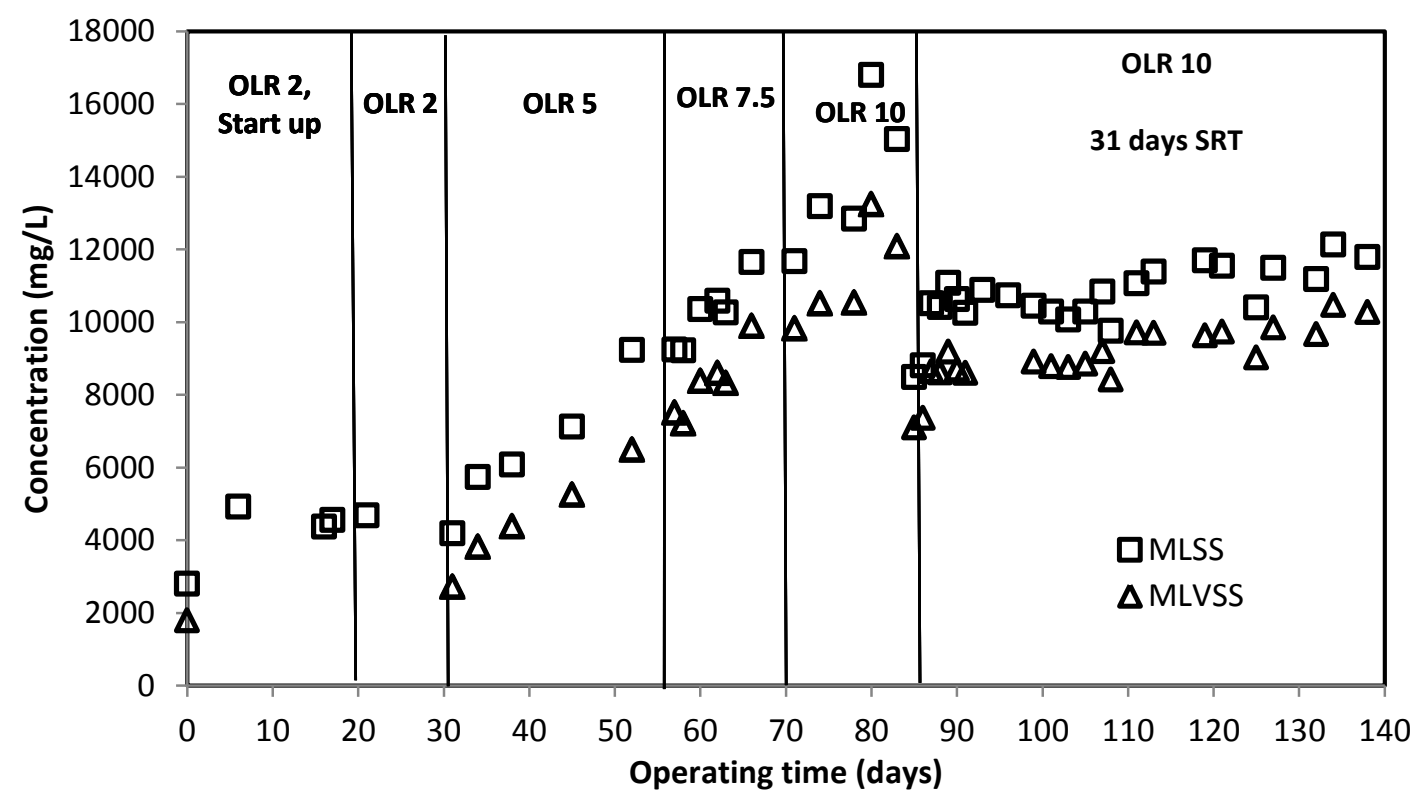

Figure 3-6 MLSS and MLVSS change with time

Biomass yield and specific growth under each operating condition were calculated and are shown in Figure 6. An average observed yield and specific growth were observed at $0.028 \pm 0.004 \mathrm{gVSS} / \mathrm{gCOD}$ and $0.029 \pm 0.002 \mathrm{gVSS} / \mathrm{gVSS} /$ day, respectively. Both yield and specific growth values are comparably lower than the typical values on the conventional anaerobic processes (Metcalf \& Eddy, 2002).

\subsubsection{Soluble Microbial Product Characteristics}

Various studies reported that the EPSs were the main contributor to membrane fouling in MBRs (Dereli et al., 2012a; Skouteris et al., 2012; Stuckey, 2012). EPSs are polymeric 
substances produced by microorganisms, mainly consisting of protein, polysaccharides and humic acid (Laspidou and Rittmann, 2002). EPSs are released during the cell metabolism as well as during starvation and stress as the cell metabolizes internal material and scavenges nutrients (Barker and Stuckey, 1999). Operating factors such as extended SRT and high organic loading rate can increase EPS production (Stuckey, 2012). In this study, protein and polysaccharide concentration in bulk sludge was analysed and it was found that both protein and polysaccharide increased gradually over the operation period at 2 and $5 \mathrm{COD} \mathrm{kg} / \mathrm{m}^{3} / \mathrm{day}$, and more rapidly at 7.5 and $10 \mathrm{COD}$ $\mathrm{kg} / \mathrm{m}^{3} /$ day (Figure 3-7). This indicated that the amount of EPS in the bulk sludge was linked to both the metabolic activity of microbial populations and the accumulation of existing EPS. The analysis also showed that protein was the major component of EPSs, where the protein/polysaccharide ratio ranged from 2.7 to 4.6.

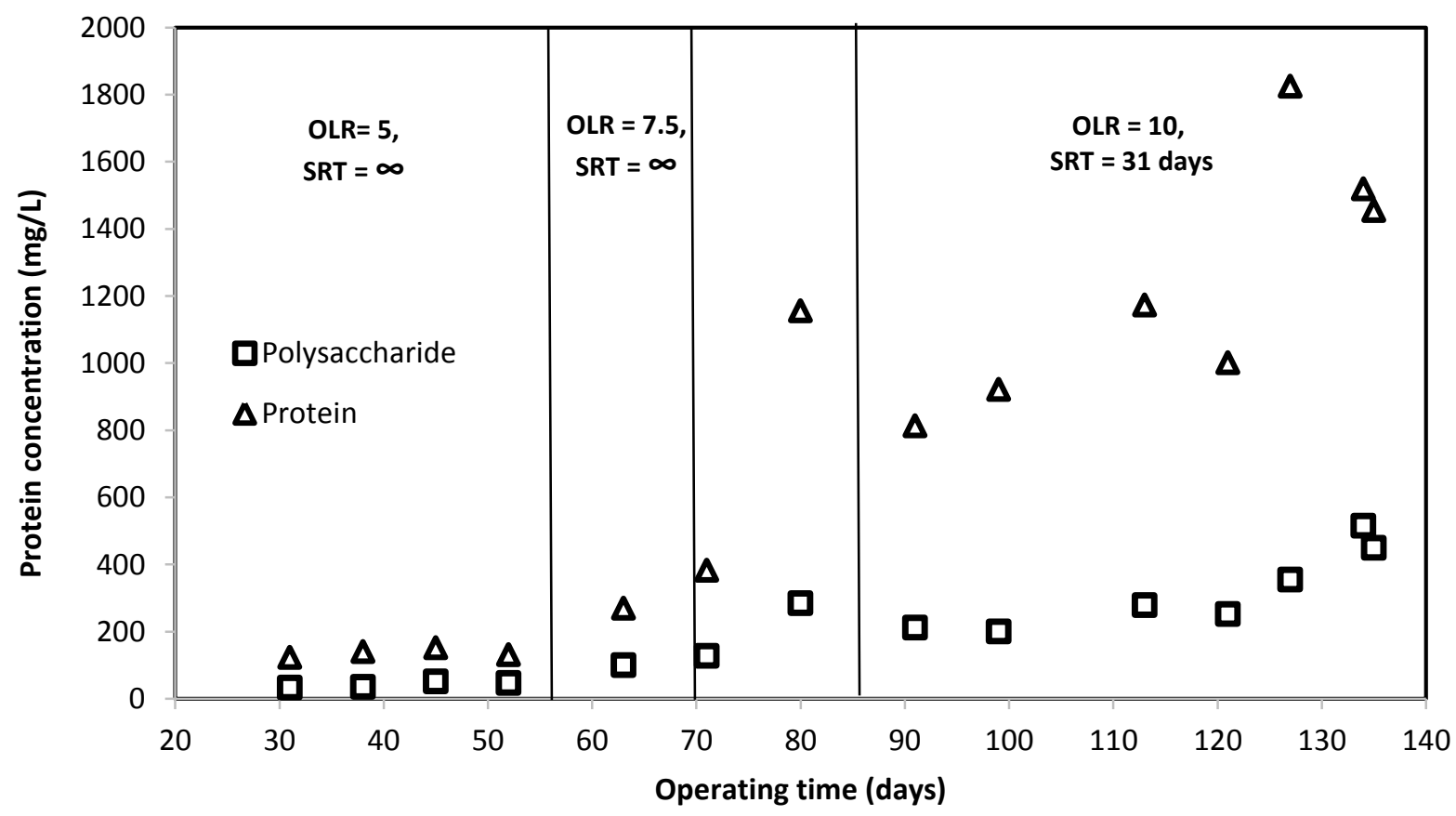

Figure 3-7 EPS concentration in bulk sludge 
EPSs in the permeate were analysed at the same time (Figure 3-8), A general tendency of higher EPS concentration was observed in higher OLR operation. The polysaccharide concentrations were found to be lower than $10 \mathrm{mg} / \mathrm{L}$ in the membrane permeate at all time, whereas over $95 \%$ polysaccharide retention was achieved by the UF membrane. In contrast, protein concentration in the membrane permeate ranged from $40 \mathrm{mg} / \mathrm{L}$ to 310 $\mathrm{mg} / \mathrm{L}$ and no correlation was observed in terms of membrane rejection. Earlier research (Ince et al., 2000) also reported that inert soluble COD in the effluent was mostly produced by the biomass and could not be removed with extended operation time.

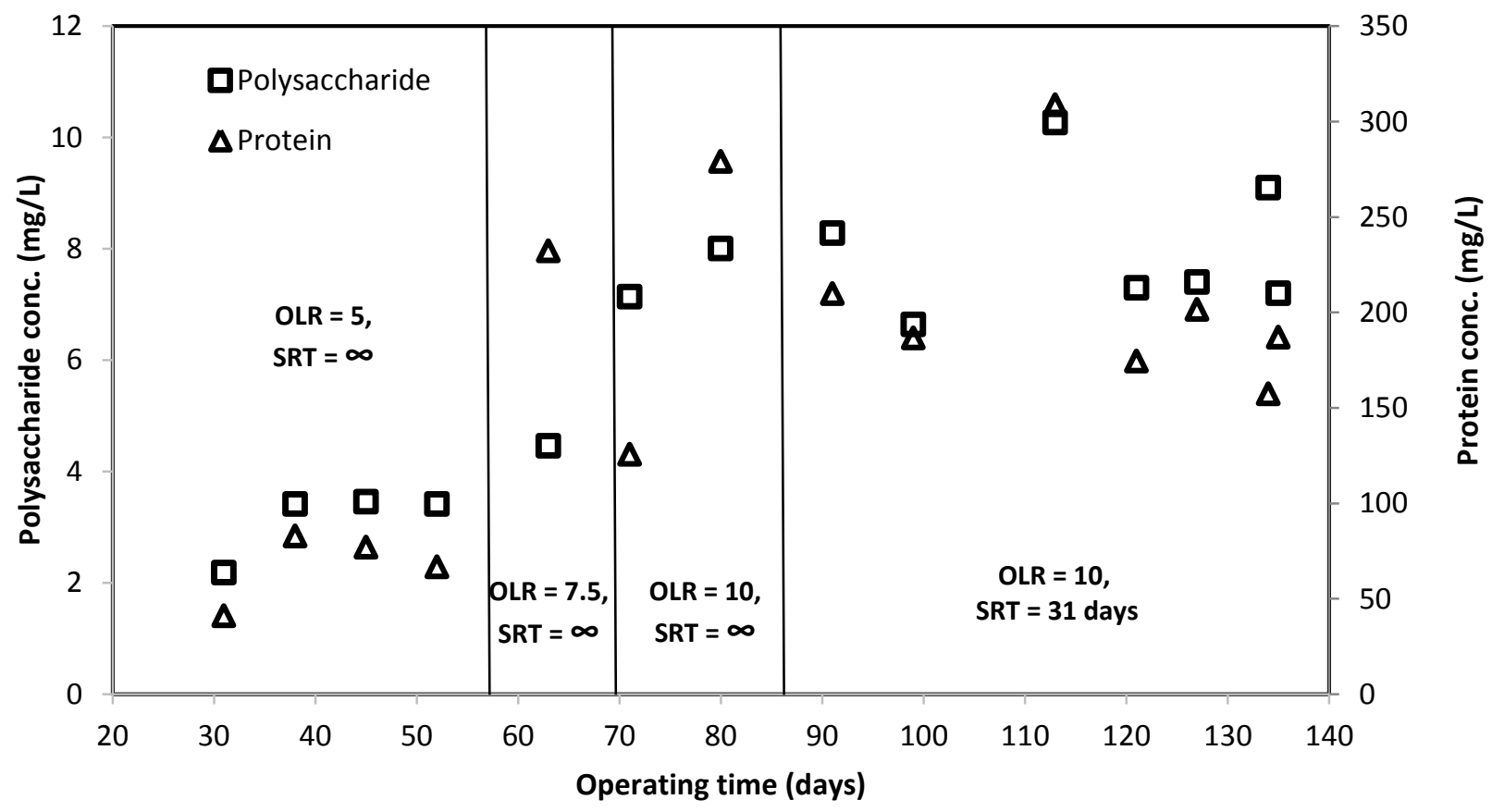

Figure 3-8 EPS concentration in permeate

Replicated filtration and EPS experiments were conducted over the OLR of $10 \mathrm{~kg} / \mathrm{m}^{3} / \mathrm{day}$ study period to investigate both protein and polysaccharide composition in the mixed liquor, shown in Figure 3-9. In the mixed liquor supernatant, it was found on average that $36 \%$ polysaccharide could pass the $0.45 \mu \mathrm{m}$ membrane filter, while only $16 \%$ of the 
protein passed through. Further, the $0.04 \mu \mathrm{m}$ membrane retained about $95 \%$ soluble polysaccharide, in contrast, over $75 \%$ soluble protein passed through the membrane. The results suggested that while most polysaccharide in soluble EPS has particle size larger than $0.04 \mu \mathrm{m}$, the distribution is bimodal with a peak in the colloidal region and a peak in the small particle size $(<0.04 \mu \mathrm{m})$ region.

\section{Protein}

\section{Polysaccharide}
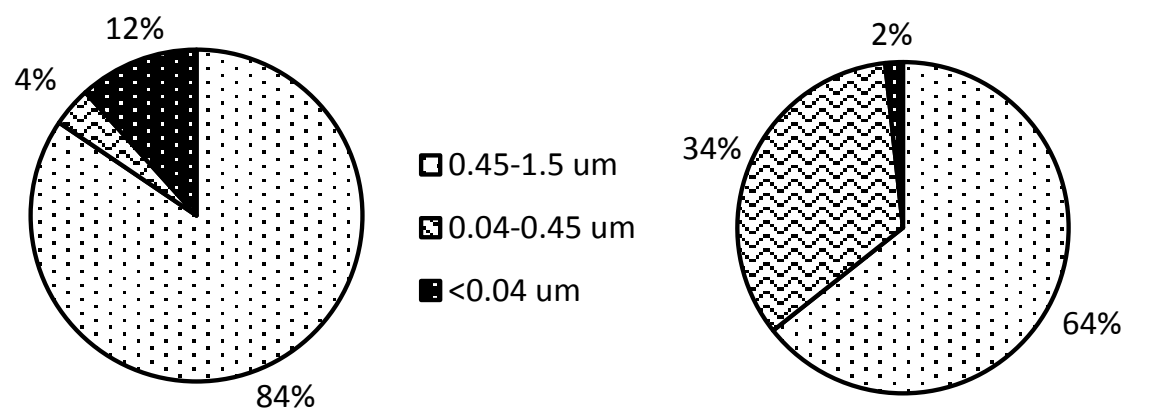

๑0.45-1.5 um

口0.04-0.45 um

. $<0.04$ um

Figure 3-9 Protein and polysaccharide composition in mixed liquor

\subsubsection{Membrane Filtration Performance}

Constant biogas recirculation rate of 12 LPM was used in the entire study, corresponding to a scouring rate about $15.3 \mathrm{~m}^{3} / \mathrm{m}^{2} / \mathrm{hr}$, similar to the reported value $17.6 \mathrm{~m}^{3} / \mathrm{m}^{2} / \mathrm{hr}$ in the earlier hollow fiber AnMBR study over high strength industrial wastewater (Diez et al., 2012). Over the 140 days study period, the transmembrane pressure (TMP) had increased 2.0 $\mathrm{kPa}$ while maintaining constant flux operation at $8 \mathrm{LMH}$ (Figure 3-10). The TMP gradually increased during OLRs of $2-7.5 \mathrm{~kg} \mathrm{COD} / \mathrm{m}^{3} /$ day operation and had a 
jump over $1.5 \mathrm{kPa}$ over the 15 days OLR $10 \mathrm{~kg} / \mathrm{m}^{3} /$ day with no sludge wasting operation and stabilized under constant SRT operation.

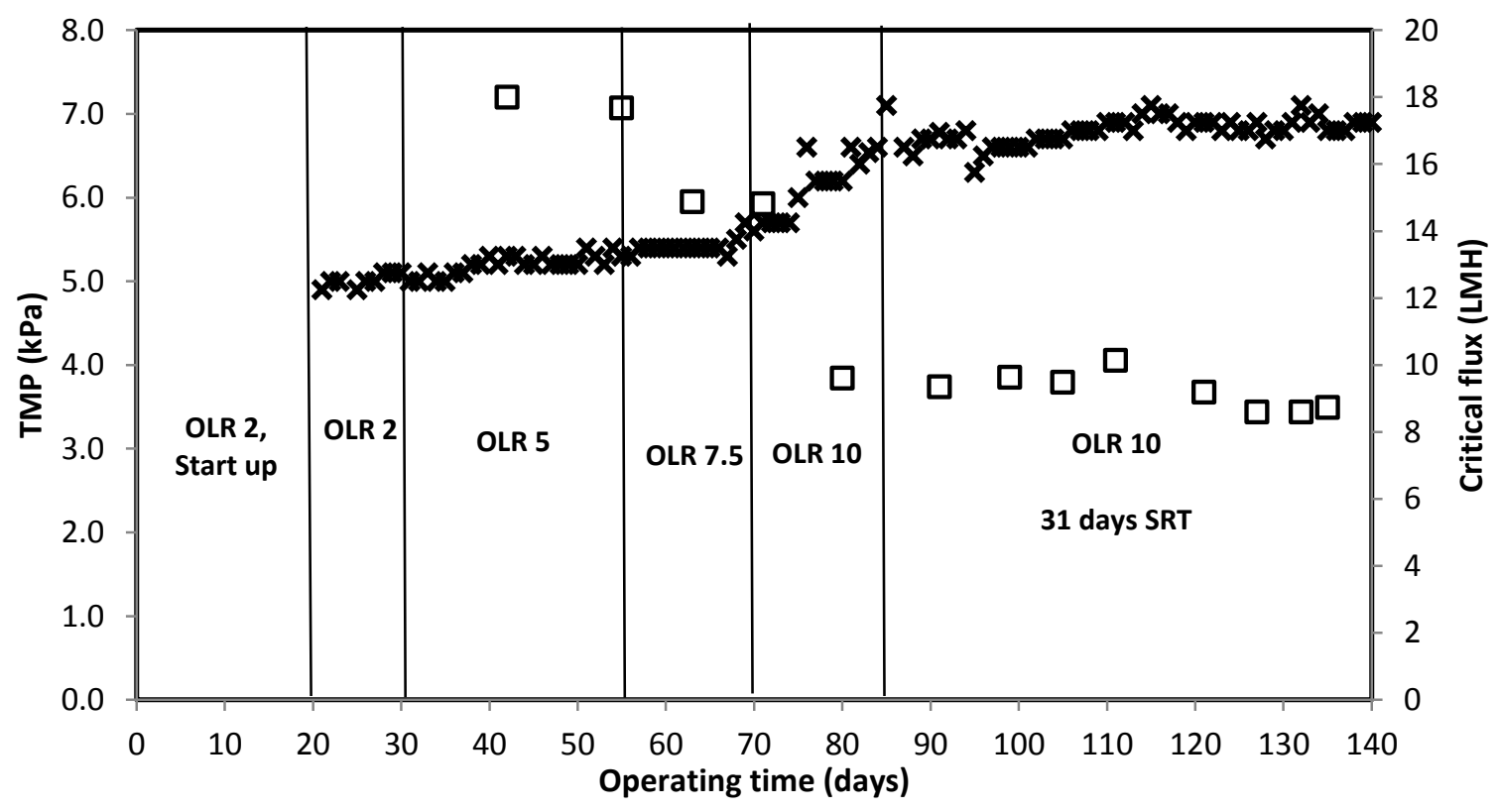

Figure 3-10 TMP and critical flux change over time

Critical flux tests were performed weekly using the flux stepping method, by increasing the flux in a 15 min step-wise fashion while monitoring the corresponding TMP. According to Le Clech et al. (2003), critical flux can be determined as the flux corresponding to an increase in TMP of $0.1 \mathrm{kPa}$ over a 10 minute duration. It was found that the critical flux was inversely proportional to the OLR, shown in Figure 3-10. The average critical flux for OLR of $5,7.5$ and $10 \mathrm{~kg} / \mathrm{m}^{3} /$ day were $17.8 \pm 0.3,14.8 \pm 0.1$ and $9.3 \pm 0.3 \mathrm{LMH}$, accordingly. 


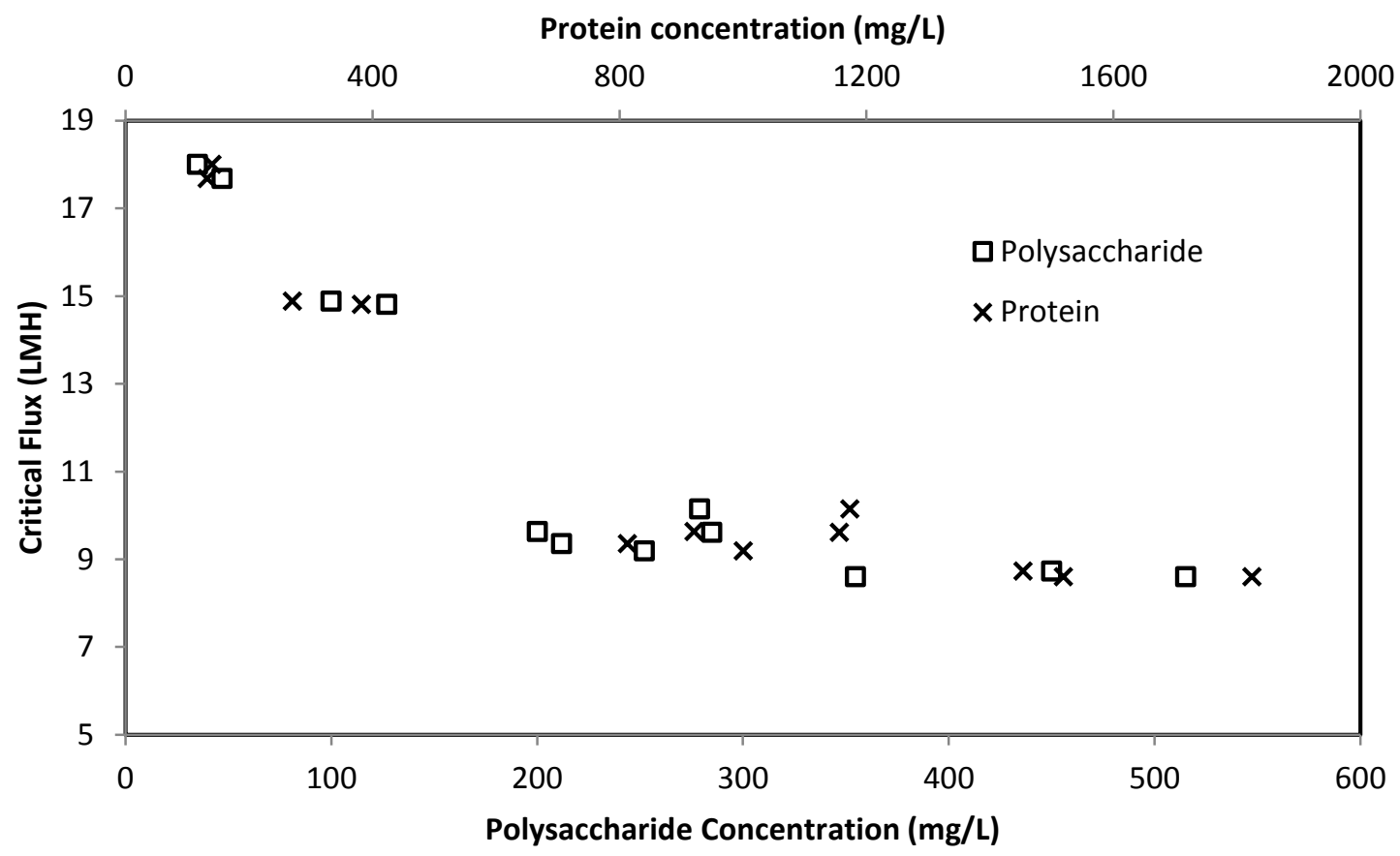

Figure 3-11 Relationship between EPS in bulk sludge and critical flux

Combining the critical flux data and EPS concentration in the bulk sludge data, a strong correlation is shown in Figure 3-11. The critical flux had decreased rapidly while the polysaccharide and protein concentration increased to $200 \mathrm{mg} / \mathrm{L}$ and $800 \mathrm{mg} / \mathrm{L}$, respectively. A more gradual drop in the critical flux was then observed at higher ranges of polysaccharide and protein concentration. Critical flux was affected by the EPS concentration in bulk sludge, where it was more sensitive when polysaccharide and protein concentrations were below $200 \mathrm{mg} / \mathrm{L}$ and $800 \mathrm{mg} / \mathrm{L}$, respectively. 


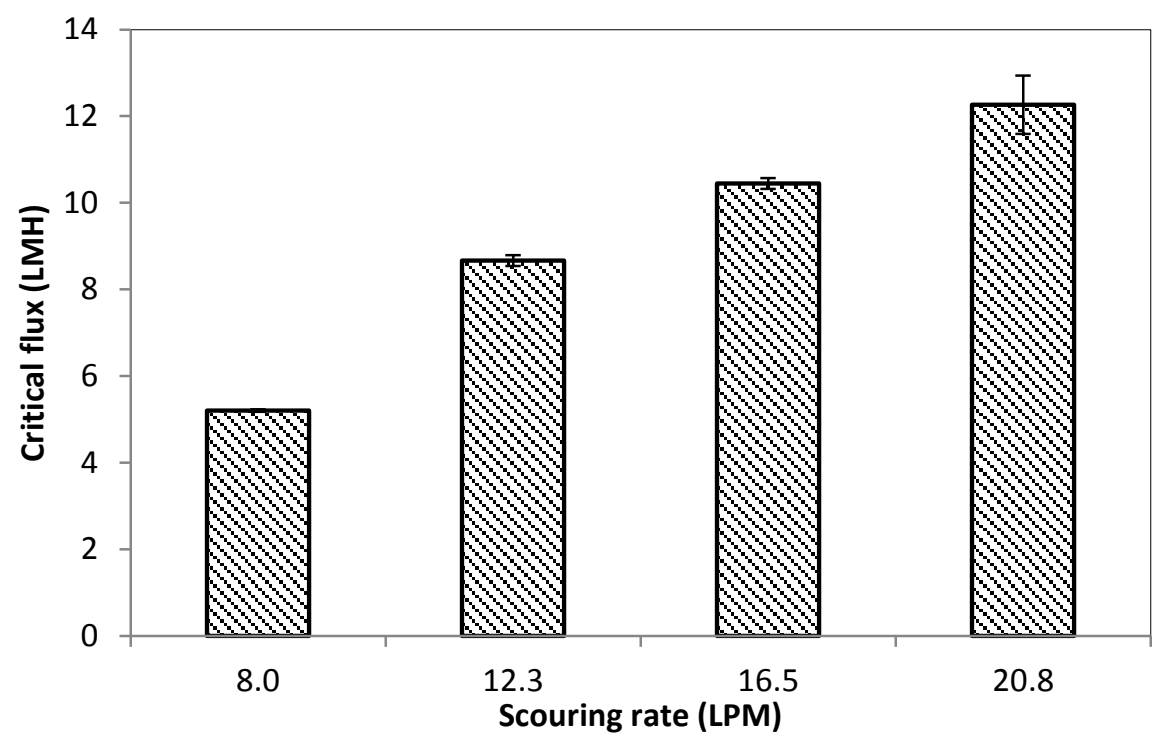

Figure 3-12 Effect of gas scouring on critical flux

Critical flux tests were conducted over different air scouring rates towards the end of study period. Four biogas recirculation rates were tested, corresponding to a normalized scouring rate of 10.2, 15.7, 21.1 and $26.5 \mathrm{~m}^{3} / \mathrm{m}^{2} / \mathrm{hr}$. The results in Figure $3-12$ indicated that the critical flux was very sensitive to the gas scouring intensity.

\subsubsection{Bench Scale Filtration System}

All three bench filtration experiments achieved over 99\% COD removal efficiency. An inversely proportional relationship between biomass concentration and permeate COD was observed, where the average permeate COD was 61,53 and $47 \mathrm{mg} / \mathrm{L}$ at 10,15 and $20 \mathrm{~g} \mathrm{MLSS/L}$, respectively. There was no significant evidence showing a difference between biogas productions at different operation fluxes for the same OLR. Under the same mixing condition, the TMP profile was found to be moderately sensitive to the biomass concentration. Critical fluxes were determined before and after the 7 day filtration test, and found to be $17.7,13.2$ and $7.9 \mathrm{LMH}$, whereas the critical flux at $20 \mathrm{~g} / \mathrm{L}$ MLSS was substantially lower. The critical flux was lower than the operating flux at 20 
$\mathrm{g} / \mathrm{L}$ condition. The filtration was not completed in full duration due to high TMP profile. After the 168 hour filtration period, the critical flux of $10 \mathrm{~g} / \mathrm{L}$ and $15 \mathrm{~g} / \mathrm{L}$ were found to be similar, at $8.8 \mathrm{LMH}$. It was found that the critical flux was strongly correlated with the EPS concentration found in bulk sludge. The fouling resistance was calculated from clean water testing. It was found that the $10 \mathrm{~g} / \mathrm{L}$ and $15 \mathrm{~g} / \mathrm{L}$ batch had an increase of $4 \%$ and $13 \%$ in filtration resistance, respectively. No physical irreversible fouling was observed in $20 \mathrm{~g} / \mathrm{L}$ due to insufficient operation time.

\subsection{CONCLUSION}

The applicability of submerged AnMBR technology for the treatment of high organic strength synthetic brewery wastewater was investigated in this study. The system achieved over 99\% COD removal efficiency, excessive methane yield and minor membrane fouling. A greater biomass yield and specific growth was observed over shorter SRTs. More EPSs were released into bulk sludge at a higher organic loading rate, due to a higher metabolism rate. It was also found that the ultrafiltration membrane retained all the suspended solids, rejected over $95 \%$ soluble polysaccharides and improved the effluent quality significantly. Not only was the gas scouring intensity was found to be an important factor to the critical flux, it was also found that the EPS concentration in bulk sludge plays an important role on membrane fouling, whereas the correlation was more sensitive when polysaccharide and protein concentrations were below $200 \mathrm{mg} / \mathrm{L}$ and $800 \mathrm{mg} / \mathrm{L}$.

Overall, this research further validates the efficacy of using AnMBR on high strength brewery wastewater treatment. The system achieved a great energy recovery while producing excellent quality effluent. However, the membrane fouling mechanism behind 
the microbial metabolism is still not fully understood at this stage. More work is needed to ascertain the composition of the fouling layer as well as the factors that influence the EPS production.

\subsection{ACKNOWLEDGEMENT}

The authors thank Ontario Ministry of Agriculture, Food and Rural Affairs (OMAFRA)

(NO 200385), Canada Foundation for Innovation (CFI) (NO. 28061), and GE Water and Process Technologies, and Ontario Centers of Excellence (CR-SW-11384-12) for supporting this research. 


\section{CHAPTER 4 - IOCAL CRAFT BREWERY WASTEWATER}

\subsection{AbStract}

Succeeding the earlier synthetic wastewater study, the anaerobic membrane bioreactor (AnMBR) technology was further subjected to an operation with high strength brewery wastewater from a local craft brewery. The characteristics of brewery effluent were analyzed and found to be highly variable in both organic strength and composition, yet highly biodegradable. The AnMBR system had gone through an operation with organic loading ranging from 3.5 to $11.5 \mathrm{~kg} \mathrm{COD} / \mathrm{m}^{3} /$ day. The system achieved over $98 \% \mathrm{COD}$, $54 \% \mathrm{TN}$ and $28 \% \mathrm{TP}$ removal efficiency and demonstrated a very stable methane yield of $0.31 \mathrm{~m}^{3} \mathrm{CH}_{4} / \mathrm{kg}$ COD at $35^{\circ} \mathrm{C}$. Effluent COD was observed at 150,170 and $270 \mathrm{mg} / \mathrm{L}$ for organic loading rates (OLRs) of 5.0, 6.5 and $11.5 \mathrm{~kg} / \mathrm{m}^{3} /$ day, respectively. AnMBR effluent contains mostly non-biodegradable organic compounds, mainly soluble protein. The ultrafiltration membrane rejected approximately $85 \%$ of soluble polysaccharide, while no significant rejection on soluble protein was observed. In comparison to the earlier synthetic wastewater study, significantly higher concentrations of EPS were found in the mixed liquor. The study recommended running the AnMBR on high strength brewery wastewater at an organic loading of $6.5 \mathrm{~kg} \mathrm{COD} / \mathrm{m}^{3} /$ day with an operation flux of $7 \mathrm{~L} / \mathrm{m}^{2} /$ hour (LMH). This research further validates the efficacy of AnMBRs for high strength brewery wastewater treatment. The system achieved great energy recovery while producing excellent quality effluent.

Keywords: Anaerobic membrane bioreactor, brewery wastewater treatment, membrane fouling, organic loading rate, anaerobic digestion, specific growth rate 


\subsection{INTRODUCTION}

Over the last decade, the brewery industry structure has changed in Canada. Large operation plants have reduced in number while the number of micro-breweries has increased considerably (Bureau, 2009). There are 47 micro-breweries in Ontario, having approximately $\$ 190$ million sales in 2010, equivalent to a 5\% share of the Ontario beer market (MEDEI, 2012). Beer brewing is a process that is highly water intensive. An average of about 7 litres of water is used per every litre of beer produced and about $70 \%$ of the intake water is discharged to the sewer (Brewers Association, n.d.). With the large growth in business, environmental impacts became a concern. In municipal by-law, there is a set maximum permissible contaminant level for the wastewater being discharged into the sewer system. The standard normally encompasses volume, $\mathrm{pH}$, suspended solids, BOD, COD, nutrients and toxic substances in the discharge water. Discharging wastewater higher than the limit often leaves the owner with a large surcharge bill (Natural Resources Canada, 2012). Paying surcharge bills to municipalities or private contractors for continuous discharge are very costly and often limit the growth of the micro-brewery business. Municipality may enforce an on-site treatment system in case of expanding the existing brewery plant.

Wastewater characteristics vary significantly among different breweries, as well as in day to day operation. Driessen and Verejiken (2003) have summarized some of the most relevant parameters, where typical brewery wastewater consists of $200-1000 \mathrm{mg} / \mathrm{L} \mathrm{TSS}$, 2000-6000 mg/L COD, 25-80 mg/L nitrogen and 10-50 mg/L phosphorous. In general, brewery wastewater effluent consists of sugar, starch, ethanol and volatile fatty acids (VFAs). In general, the brewery wastewater is easily biodegradable with a high 
$\mathrm{BOD} / \mathrm{COD}$ ratio of 0.6 to 0.7 . Instead of relying on the municipalities treating brewery wastewater aerobically, anaerobic systems have become a more attractive on-site treatment option. The advantages include a lower sludge production, smaller foot print and more importantly, the ability to produce valuable biogas. Anaerobic treatment in the brewing industry is a proven technology. There are several types of anaerobic systems currently being used to treat brewery wastewater, with the upflow anaerobic sludge blanket (UASB) being the most common (Brito et al., 2007). Since anaerobic bacteria require a longer growth period, immobilizing bacterial sludge is necessary. UASB retains biomass by forming dense granules with high settleability. The wastewater degrades as it flows vertically upward through the dense bed of granular sludge (Rajeshwari et al., 2000). However, sustaining the granules becomes a challenge as the organic loading or $\mathrm{pH}$ shock from the batch brewing operation can result in degranulation and biomass washout. Requirement of highly skilled operation and long restart periods are also major drawbacks. More advanced technology anaerobic membrane bioreactors (AnMBRs) are being revitalized by academia and membrane solution providers lately. With the integration of ultrafiltration (UF) membranes, the AnMBRs can entirely retain the biomass and solids, thus offering a complete separation between SRT and HRT as well as a high tolerance to pH and OLR shocks (Dereli et al., 2012a). Although the AnMBR technology is more industrialized in some European countries, it is still in the developing stage in other parts of the world. Recently, General Electric has announced their first full scale AnMBR installation at Dogfish Head Craft Brewery in Milton, DE to reuse their industrial wastewater, where the system is expected to reduce wastewater volume by $80 \%$ (GE Water \& Process Technologies, 2014). 
The performance of a state-of-the-art AnMBR system was evaluated earlier using synthetic brewery wastewater adopted from Scampini (2010), with a COD:N:P ratio of approximately 260:4:1. The pilot system had gone through an operation over various organic loading rates (OLRs) ranging from 2 to $10 \mathrm{~kg} \mathrm{COD} / \mathrm{m}^{3} /$ day and sustained long term stable operation over $10 \mathrm{~kg} / \mathrm{m}^{3} /$ day at $11 \pm 1 \mathrm{~g} / \mathrm{L}$ MLSS with observed SRT of 31 days. The AnMBR had a quick start-up and demonstrated a high tolerance to the changes in wastewater organic strength. Overall, the system achieved over 99\% COD removal efficiency, excessive methane yield at $0.38 \mathrm{~m}^{3} \mathrm{CH}_{4} / \mathrm{kg} \mathrm{COD}$ and minor membrane fouling. Considering results from the synthetic wastewater study, the efficacy of AnMBR technology was further investigated in this study over high strength brewery wastewater sampled from a local craft brewery. The system was subjected to an operation with higher organic loading fluctuation and more complex wastewater composition. The performance and tolerance of the AnMBR was challenged. In addition, this study examined the extracellular polymeric substances (EPSs) production and membrane fouling mechanism under a low biomass concentration, to evaluate whether if the low biomass operation is more practical for AnMBRs. 


\subsection{MATERIALS AND MethodS}

\subsubsection{AnMBR System}

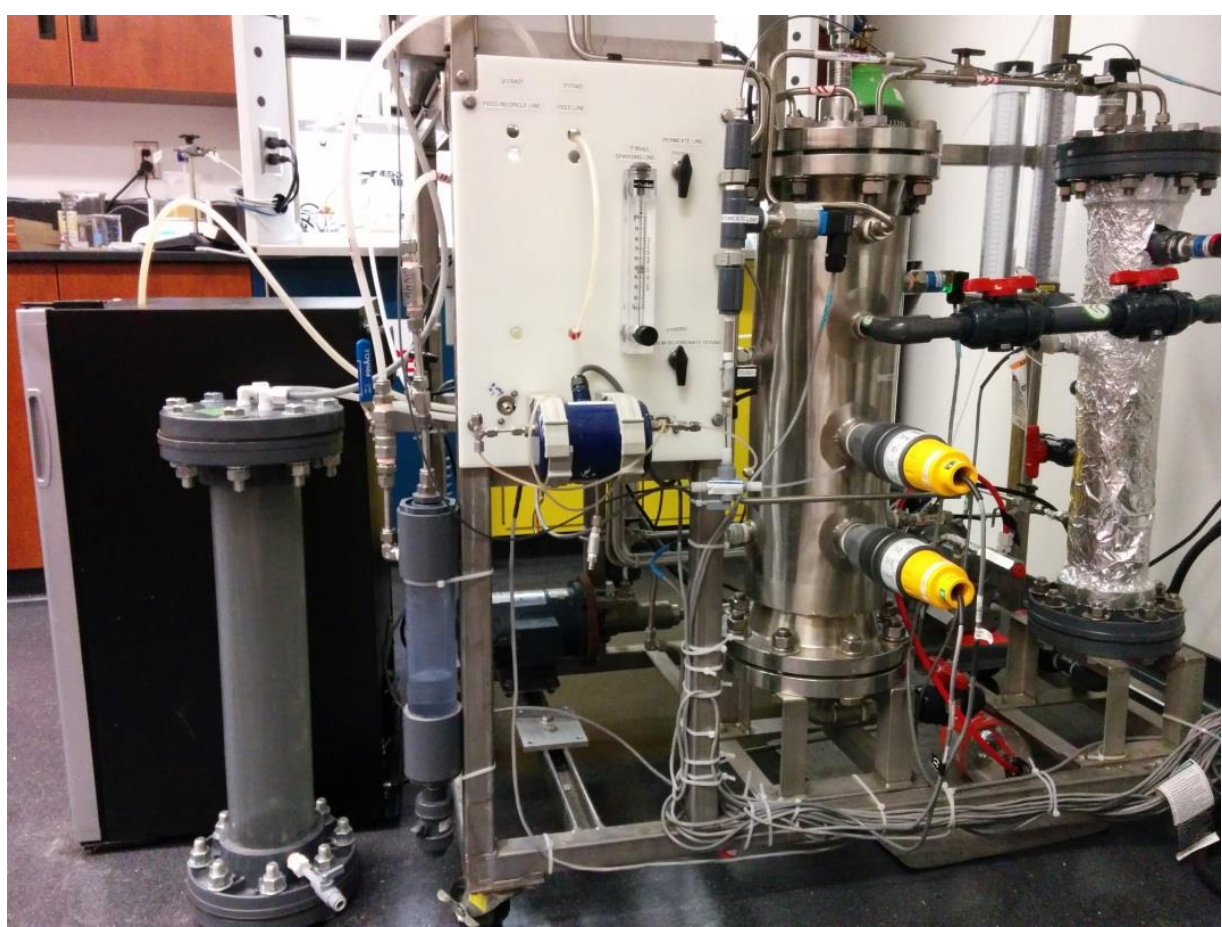

Figure 4-1 AnMBR system showing digester (centre) and membrane tank (right)

As shown in Figure 4-1, the lab-scale AnMBR used in this study consisted of a complete mix anaerobic digester and a membrane tank. Continuous mixing was performed in the anaerobic reactor using a mechanical mixer (Eurostar, IKA). The mixed liquor was recirculated from the anaerobic reactor to the bottom of the membrane tank and overflowed from the top portion of the membrane tank back to the reactor. A submerged hollow fiber membrane module with a total surface area of $0.047 \mathrm{~m}^{2}$ (GE Water and Process Technologies, Oakville $\mathrm{ON}$ ) was used for liquid-solid separation. A peristaltic pump (Miniplus 3, Gilson) was installed to extract permeate at a constant flux and the biogas was recirculated to the membrane tank for membrane scouring. Pressure sensors (Cerabar T, Endress Hauser) were installed on the digester tank and permeate line to 
monitor the system pressure and transmembrane pressure (TMP), respectively. Level sensors were used to control the feed pump to maintain a work volume of $15 \mathrm{~L}$ in the system. The bioreactor temperature was maintained by recirculating hot water in the water jacket. System $\mathrm{pH}$ was controlled by dosing sodium bicarbonate using a diaphragm metering pump (Stepdos 08, KNF). Biogas production was measured on-line by a mass flow meter (Burkert 8700). A PLC system was used to control the AnMBR system and for the collection of operation data.

\subsubsection{Wastewater Characteristics}

This study used high strength brewery wastewater from a local craft brewery. Weekly sampling of 4 x 20 liter wastewater was conducted. The $20 \mathrm{~L}$ container was placed in a bar refrigerator $\left(6^{\circ} \mathrm{C}\right)$ and was directly connected to an AnMBR feed pump. Excess wastewater was stored in a cooler room $\left(4^{\circ} \mathrm{C}\right)$ prior to use during the week. Characteristics of each batch were tested and will be further discussed in the results section.

\subsubsection{AnMBR Operation}

The reactor was started in an active state inherited from the previous synthetic brewery wastewater study, with initial MLSS and MLVSS concentrations of $11800 \mathrm{mg} / \mathrm{L}$ and $10200 \mathrm{mg} / \mathrm{L}$, respectively. The reactor had gone through 90 days continuous operation at a constant HRT of 44 hours. The OLR varied from 3.5 to $11.5 \mathrm{~kg} / \mathrm{m}^{3} /$ day and a target active biomass concentration of $7000 \mathrm{mg} / \mathrm{L}$ MLVSS was maintained by changing the daily sludge wasting volume. An average SRT was then calculated for each OLR condition, shown in Table 4-1. 


\begin{tabular}{ccc}
\multicolumn{4}{c}{ Table 4-1 } & Operation conditions during the study \\
\hline Days & OLR (g/L/d) & SRT (d) \\
\hline $\mathbf{0 - 7}$ & 6.5 & 30 \\
$\mathbf{8 - 1 2}$ & 11.5 & 17 \\
$\mathbf{1 3 - 2 9}$ & 6.5 & 30 \\
$\mathbf{3 0 - 5 0}$ & 3.5 & 46 \\
$\mathbf{5 1 - 9 0}$ & 5.0 & 50 \\
\hline
\end{tabular}

The AnMBR was operated at $\mathrm{pH} 7.02 \pm 0.01$ and temperature of $35.5 \pm 0.1{ }^{\circ} \mathrm{C}$. An online alkalinity dosing system was used to maintain the desired $\mathrm{pH}$ condition and the total alkalinity in the mixed liquor during the operation period. Constant filtration flux was set at $8 \mathrm{LMH}$ and the operation cycle involved 10 minute permeation and $1 \mathrm{~min}$ relaxation throughout the entire study. Weekly online maintenance cleaning using 2000 $\mathrm{mg} / \mathrm{L}$ citric acid and $2000 \mathrm{mg} / \mathrm{L}$ sodium hypochlorite was implemented. The maintenance cleaning operation involved 15 minute backwash cycle at permeation flux with each cleaning reagent.

\subsubsection{Analytical Methods}

Samples were regularly taken from the digester, membrane tank and membrane permeate for analysis. The supernatant of the mixed liquor was obtained using a centrifugation/filtration procedure with centrifugation at $8000 \mathrm{rpm}$ for $15 \mathrm{~min}$ at $4{ }^{\circ} \mathrm{C}$ followed by filtration through a $1.5 \mu \mathrm{m}$ filter paper, and the soluble samples were further filtered through $0.45 \mu \mathrm{m}$ disposable filters.

The Standard Methods (APHA-AWWA-WEF, 2005) were used for the measurements of total suspended solid (TSS), mixed liquor suspended solids (MLSS) and mixed liquor volatile suspended solids (MLVSS). Wastewater parameters including chemical oxygen 
demand (COD), total nitrogen (TN), total phosphours (TP), ammonia nitrogen $\left(\mathrm{NH}_{4}{ }^{+}-\mathrm{N}\right)$, nitrate nitrogen $\left(\mathrm{NO}_{3}{ }^{-} \mathrm{N}\right)$, nitrite nitrogen $\left(\mathrm{NO}_{2}{ }^{-} \mathrm{N}\right)$, phosphate phosphorus $\left(\mathrm{PO}_{4}{ }^{-3}-\mathrm{P}\right)$, and volatile fatty acids (VFA) were measured using Hach methods (HACH, 2008). Protein and polysaccharide concentrations of EPS and EPS were determined with the Bradford method (Bradford, 1976) and the phenol-sulphuric acid method (DuBois et al., 1956), respectively. Bovine serum albumin (BSA) and glucose were used as standard references and the absorbance was taken by a spectrophotometer (DR5000, Hach). Total alkalinity was measured using an automatic titrator (TitraLab 870, Radiometer analytical). Biogas composition was analysed using gas chromatograph service from a commercial lab (ALS Environmental).

\subsection{RESULTS AND DISCUSSION}

\subsubsection{Brewery Wastewater Characteristic}

Wastewater quality indication parameters including $\mathrm{pH}$, Total Alkalinity, TSS, VSS, BOD, tCOD, sCOD, TN, TP, $\mathrm{NH}_{3}-\mathrm{N}$ and $\mathrm{PO}_{4}-\mathrm{P}$ were analyzed on every batch, shown in Table 4-2. Due to the batch brewing operation, the wastewater strength and characteristic fluctuated significantly from batch to batch. BOD/COD ratio observed to the range from 0.5 to 0.77 , indicating the efficacy of biological treatment (Metcalf \& Eddy, 2002). Based on the average analysis readings, the craft brewery wastewater had a $\mathrm{C}: \mathrm{N}: \mathrm{P}$ ratio of 200:3.2:1 with an average COD of $11000 \pm 2800 \mathrm{mg} / \mathrm{L}$ and over $90 \%$ was soluble COD. The wastewater contained suspended solids at $950 \pm 450 \mathrm{mg} / \mathrm{L}$, primarily from mash tun and filter cleaning, with a VSS/TSS ratio ranged from 48 to $97 \%$. Due to the high protein content in the wastewater, over $95 \%$ nitrogen and over $50 \%$ phosphorus was 
organic. The wastewater was slightly acidic, with $\mathrm{pH} 5.7 \pm 0.5$ and has a total alkalinity of $270 \pm 80 \mathrm{mg} / \mathrm{L}$ as $\mathrm{CaCO}_{3}$.

Table 4-2 Brewery wastewater characteristic

\begin{tabular}{|c|c|c|c|c|c|c|c|c|c|c|}
\hline Batch & TSS & VSS & tCOD & sCOD & TN & $\mathbf{T P}$ & $\begin{array}{c}\text { NH3- } \\
\text { N }\end{array}$ & $\begin{array}{c}\text { PO4- } \\
\text { P }\end{array}$ & pH & Alk \\
\hline Unit & $\mathrm{mg} / \mathrm{L}$ & $\mathrm{mg} / \mathrm{L}$ & $\mathrm{mg} / \mathrm{L}$ & $\mathrm{mg} / \mathrm{L}$ & $\mathrm{mg} / \mathrm{L}$ & $\mathrm{mg} / \mathrm{L}$ & $\mathrm{mg} / \mathrm{L}$ & $\mathrm{mg} / \mathrm{L}$ & - & $\mathrm{meq} / \mathrm{L}$ \\
\hline 1 & 1380 & 200 & 18140 & 17000 & 372.0 & 136.0 & 6.9 & 107.4 & 5.2 & 3.6 \\
\hline 2 & 1270 & 30 & 12080 & 10980 & 145.2 & 36.2 & 5.5 & 17.1 & 6.6 & 49.1 \\
\hline 3 & 680 & 560 & 11500 & 10380 & 131.0 & 31.2 & 15.5 & 15.8 & 6.0 & 9.9 \\
\hline 4 & 310 & 250 & 19140 & 15720 & 156.0 & 36.7 & 5.8 & 17.5 & 7.2 & 43.4 \\
\hline 5 & 625 & 298 & 11180 & 10660 & 89.5 & 25.3 & 8.5 & 12.0 & 4.9 & 2.3 \\
\hline 6 & 301 & 293 & 5950 & 5420 & 74.5 & 22.3 & 11.3 & 11.8 & 5.7 & 6.4 \\
\hline 7 & 1395 & 1242 & 6580 & 5940 & 560.0 & 35.1 & 11.6 & 11.5 & 5.8 & 5.4 \\
\hline 8 & 2614 & 2131 & 8900 & 8480 & 92.9 & 37.4 & 6.9 & 21.0 & 5.5 & 7.2 \\
\hline 9 & 674 & 384 & 8950 & 8870 & 70.5 & 14.5 & 2.3 & 8.1 & 4.9 & 4.0 \\
\hline 10 & 266 & 232 & 8410 & 8430 & 77.6 & 186.0 & 3.3 & 39.7 & 5.5 & 4.0 \\
\hline Avg & 950 & 770 & 11080 & 10190 & 180 & 55 & 8 & 26 & 5.7 & 13.5 \\
\hline & \pm 450 & $\pm \mathbf{3 9 0}$ & \pm 2760 & \pm 2320 & \pm 100 & \pm 35 & \pm 3 & \pm 19 & \pm 0.5 & \pm 10.8 \\
\hline Min & 266 & 232 & 5950 & 5420 & 71 & 15 & 2 & 8 & 4.9 & 2.3 \\
\hline Max & 2614 & 2131 & 19140 & 17000 & 560 & 186 & 16 & 107 & 7.2 & 49.1 \\
\hline
\end{tabular}




\subsubsection{COD Removal Efficiency}

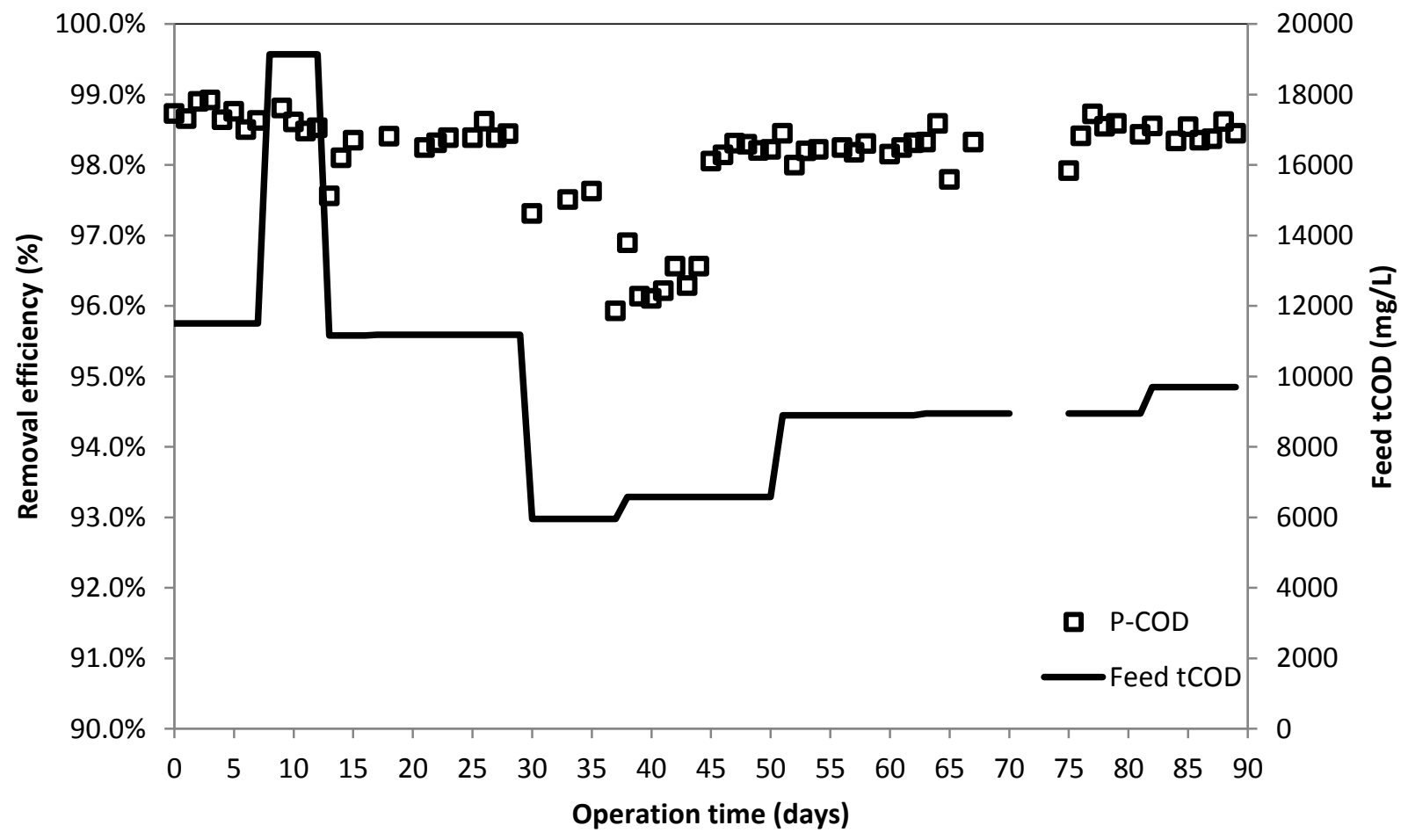

Figure 4-2 Influent COD and removal efficiency

The AnMBR system was continuously operated for 90 days on 10 batches of brewery wastewater, excluding day 71 to 74 , during which the recirculation pump was failed, but a new pump was installed on day 75 and the operation was resumed. Figure 4-2 shows the influent COD concentration in black lines and the overall system COD removal efficiency. Figure 4-3 shows the effluent COD and VFA concentration. The influent COD varied from $6000 \mathrm{mg} / \mathrm{L}$ to $19100 \mathrm{mg} / \mathrm{L}$ which corresponded to OLRs from 3.5 to $11.5 \mathrm{~kg} / \mathrm{m}^{3} /$ day. The effluent COD fluctuated with OLR, but the maximum effluent COD observed during the operation was below $300 \mathrm{mg} / \mathrm{L}$ at all time. An average effluent COD of $149 \pm 7 \mathrm{mg} / \mathrm{L}$ and $172 \pm 15 \mathrm{mg} / \mathrm{L}$ was observed under the OLR of 5 and $6.5 \mathrm{~kg} / \mathrm{m}^{3} / \mathrm{day}$ operation, respectively, with VFA concentration under detection limit (50 mg/L). A high 
effluent COD concentration at $268 \pm 21 \mathrm{mg} / \mathrm{L}$ with a detectable VFA concentration at 81 $\pm 5 \mathrm{mg} / \mathrm{L}$ was observed during OLR $11.5 \mathrm{~kg} / \mathrm{m}^{3} /$ day operation. The VFA residual in the mixed liquor at OLR $11.5 \mathrm{~kg} / \mathrm{m}^{3} /$ day indicated an incomplete biodegradation. The fluctuation in effluent COD was significantly smaller than the changes in the influent COD and operation OLR, indicating that the AnMBR had a high tolerance to organic loading changes from batch brewing operations, while maintaining good quality effluent free of solid. This was likely due to the retention of the suspended solids and colloidal substances by the membrane, compared to the conventional high rate anaerobic reactors.

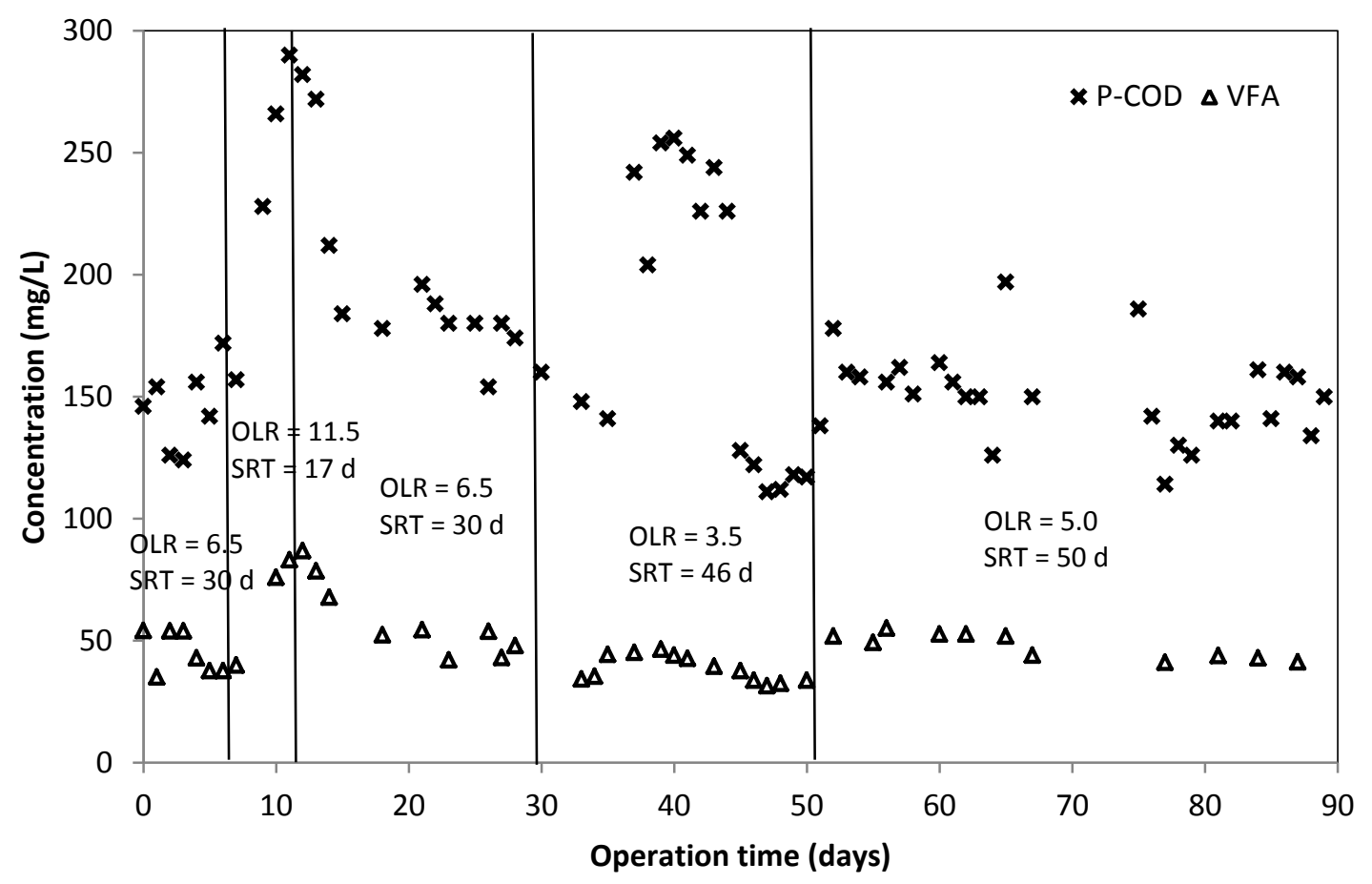

Figure 4-3 Effluent COD and VFA concentration

In all of the above OLR operations, the AnMBR system has achieved over 98\% COD removal efficiency, with the exception from day 30 to day 44 , where the removal efficiency dropped below $98 \%$. During day 30 to 35 , the removal efficiency dropped to 
97\%, which was caused by the decrease of influent COD concentration thus resulting in a higher effluent/influent COD ratio in the removal efficiency calculation. During day 37 to day 44 , the effluent COD concentration increased to $250 \mathrm{mg} / \mathrm{L}$, dropped the removal efficiency down to $96 \%$. The cause was argued to be the abnormal wastewater being fed into AnMBR during day 30 to day 37. The TSS and COD concentration of that batch of wastewater was comparably lower; however, the influent wastewater potentially contained cleaning detergent or other compounds, which could be toxic to the biomass. The toxic effect on the biomass had a delay of approximately 6 days and the bioreactor recovered in 7 days after the feed batch was switched on day 38 . On day 45 , the effluent COD concentration dropped below $150 \mathrm{mg} / \mathrm{L}$ and maintained overall removal efficiency above $98 \%$ for the rest of the study. With no acidification observed, the CSTR design of AnMBR established a high tolerance to toxic load and demonstrated a quick recovery, while suspended biomass was believed to be more susceptible for toxicants than granular sludge (Dereli et al., 2012a). 


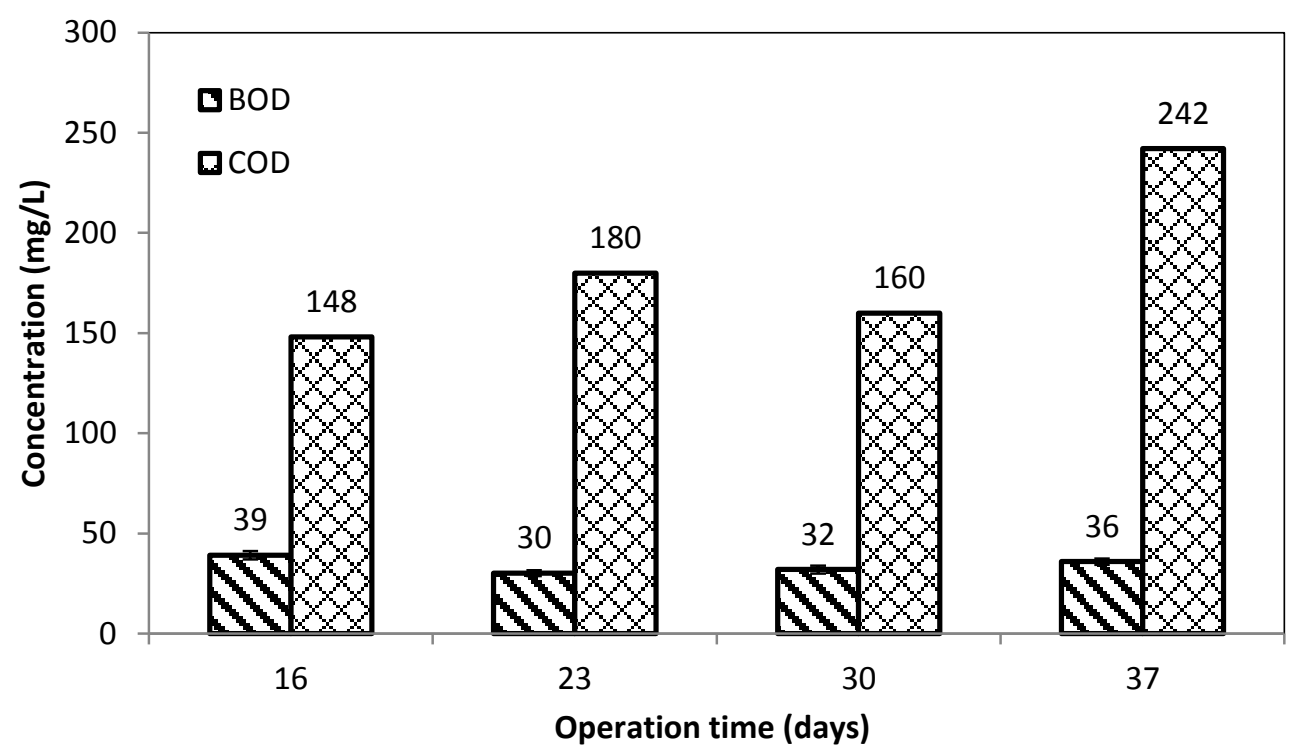

Figure 4-4 Effluent BOD and COD concentration comparison

Figure 4-4 shows the BOD and COD concentration in the effluent. The BOD

concentration remained in the range of 30 to $40 \mathrm{mg} / \mathrm{L}$, while the effluent COD fluctuated with the operation OLR. The low BOD/COD ratio $(0.20 \pm 0.05)$ suggest that the AnMBR effluent mostly contains non-biodegradable soluble substance, likely EPSs, which will be further discussed in the later section.

\subsubsection{COD in the Mixed Liquor}

The results demonstrated that the membrane filtration played an important role in improving the treatment performance of anaerobic digestion and the effluent quality. As shown in Figure 4-5, a significant difference was observed between the COD concentration in $1.5 \mu \mathrm{m}$ sludge filtrate, $0.45 \mu \mathrm{m}$ soluble filtrate and $0.04 \mu \mathrm{m}$ ultrafiltration permeate. The permeate COD was found to be significantly lower (170 \pm $36 \mathrm{mg} / \mathrm{L}$ ), with the ratios to $1.5 \mu \mathrm{m}$ and $0.45 \mu \mathrm{m}$ sludge filtrate calculated to be $0.06 \pm$ 0.01 and $0.16 \pm 0.03$, respectively. 


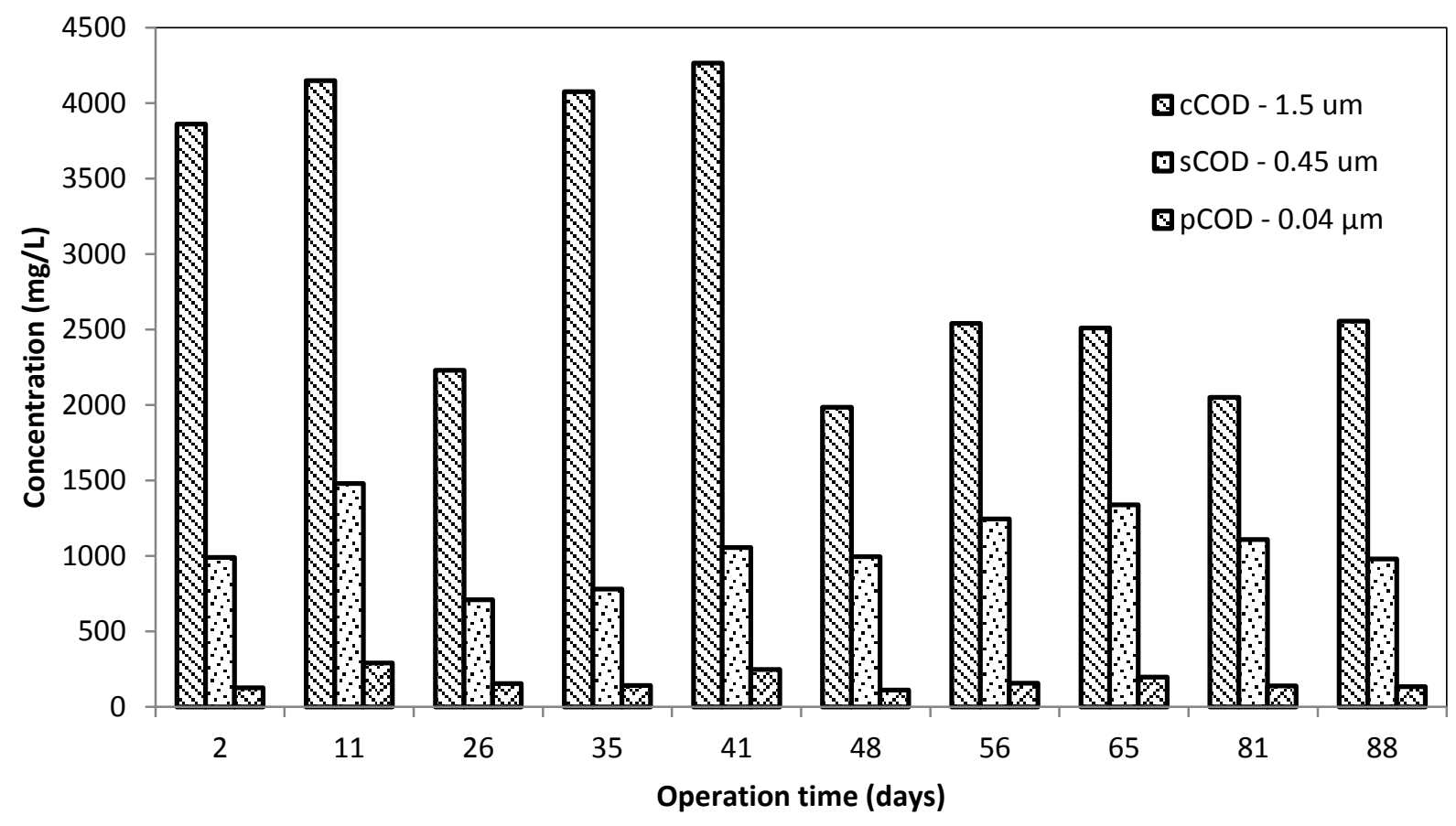

Figure 4-5 COD concentration in the $1.5 \mu \mathrm{m}, 0.45 \mu \mathrm{m}$ filtrate and membrane permeate

In addition, while the permeate COD remained relatively low and stable for all the organic loading rates tested, the COD concentration in the $1.5 \mu \mathrm{m}$ filter paper and 0.45 $\mu \mathrm{m}$ membrane filtrate of the mixed liquor increased with the organic loading rate. With the exemption on day 35 and 41 , while the operation OLR was at $3.5 \mathrm{~kg} / \mathrm{m}^{3} / \mathrm{day}$, the 1.5 $\mu \mathrm{m}$ sludge filtrate COD was abnormal and comparably higher, which does not reflect the relationship between feed wastewater organic strength and sludge COD. The higher colloidal COD (cCOD) to soluble COD (sCOD) ratio during this period suggested the increase in COD was not due to incomplete degradation of influent wastewater, rather a larger presence of colloidal organic substances released from the biodegradation process. This argument is also supported by the protein and polysaccharide data shown in the later EPS section. This phenomenon may perhaps relate to the abnormal intake wastewater from day 30 to day 37 , which potentially caused a greater release of microbial products. 


\subsubsection{Biogas Production}

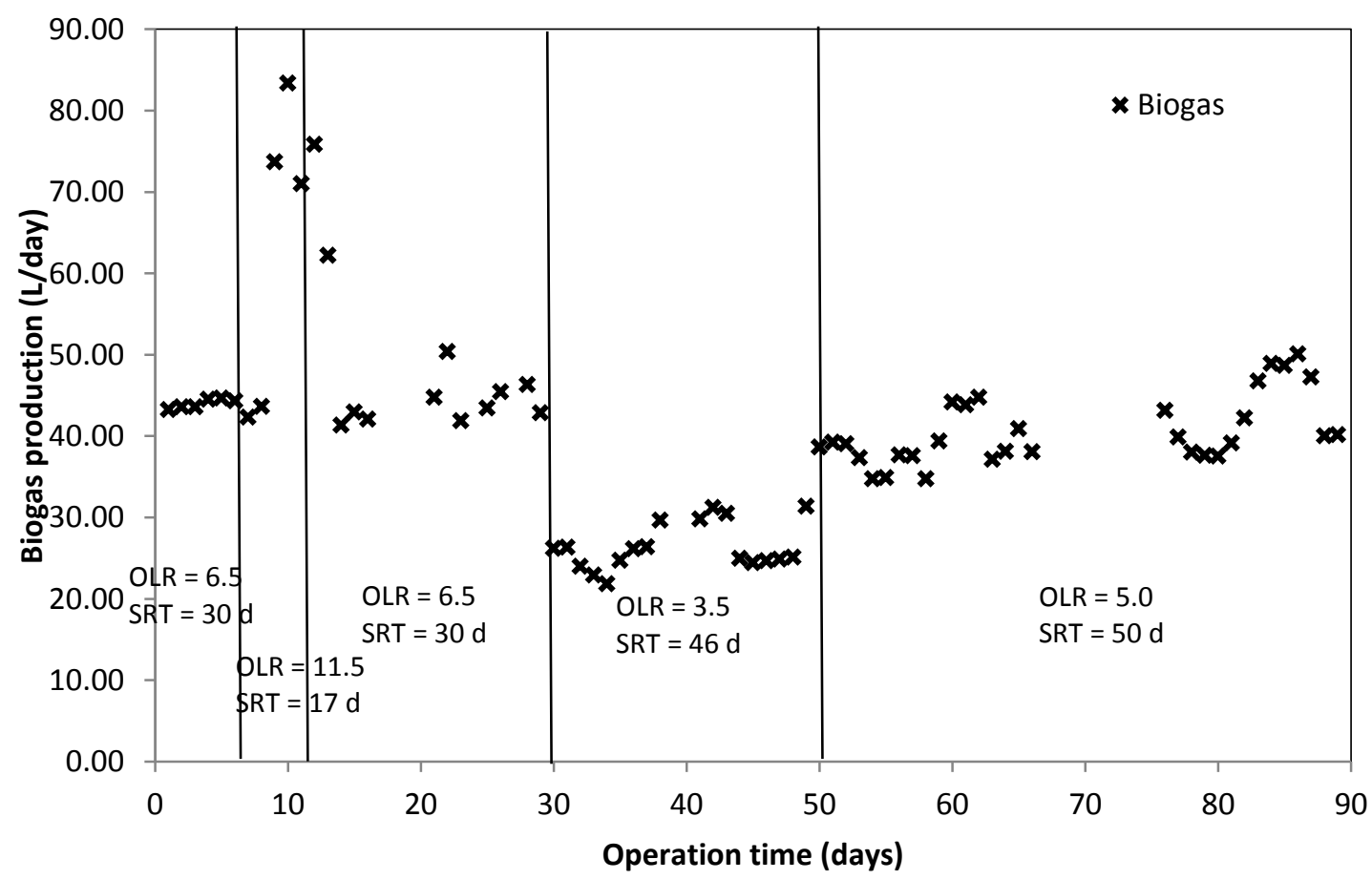

Figure 4-6 Biogas production under various OLR operation

The biogas production rate was very stable under each organic loading rate (Figure 4-6).

Daily biogas production for OLR 3.5, 5.0 and $6.5 \mathrm{~kg} \mathrm{COD} / \mathrm{m}^{3} /$ day was measured at 27.1

$\pm 1.8,40.7 \pm 1.6$ and $44.0 \pm 0.9$ 1/day, respectively. Gas chromatography analysis

reported a biogas composition of $59 \% \mathrm{CH}_{4}, 31 \% \mathrm{CO}_{2}, 10 \% \mathrm{~N}_{2}$ and no significant

detectable $\mathrm{CO}$ and $\mathrm{O}_{2}$, which demonstrated a feasible energy recovery, having an overall methane yield of $0.31 \pm 0.01 \mathrm{~m}^{3} \mathrm{CH}_{4} / \mathrm{kg} \mathrm{COD}$ removed $\left(35^{\circ} \mathrm{C}\right)$, at $79 \%$ of the maximum theoretical value. 


\subsubsection{Bicarbonate Dosage}

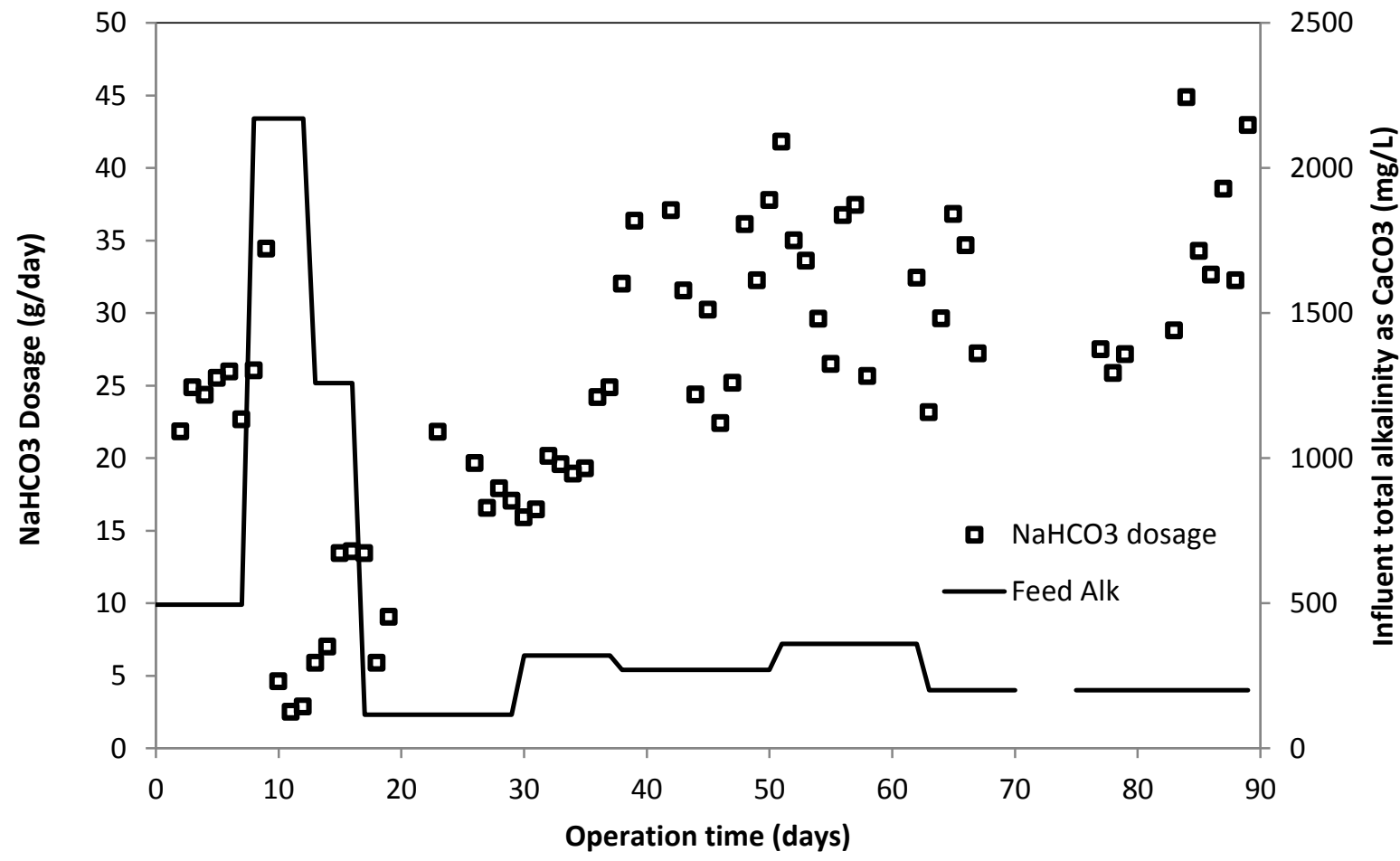

Figure 4-7 Influent total alkalinity and sodium bicarbonate dosage over the study

The $\mathrm{pH}$ and total alkalinity of the mixed liquor in the reactor were controlled to have favorable conditions for methanogenesis. Figure 4-7 shows the influent wastewater total alkalinity in black lines and the sodium bicarbonate dosage over the study. Excluding two batches from earlier stage of study, the influent wastewater was slightly acidic in general, with a low alkalinity of $270 \pm 80 \mathrm{mg} / \mathrm{L}$ as $\mathrm{CaCO}_{3}$. With the intention of maintaining a favorable $\mathrm{pH}$ and total alkalinity in the mixed liquor at $7.02 \pm 0.01$ and $2800 \pm 150 \mathrm{mg} / \mathrm{L}$ as $\mathrm{CaCO}_{3}$, respectively, sodium bicarbonate was added to the digester. An average of $30 \pm 2 \mathrm{~g} \mathrm{NaHCO}_{3}$ was dosed per day, corresponding to a bicarbonate dosing rate of $3.7 \pm 0.3 \mathrm{~kg} \mathrm{NaHCO}_{3} / \mathrm{m}^{3}$ wastewater or $0.47 \pm 0.03 \mathrm{~kg} \mathrm{NaHCO}_{3} / \mathrm{kg} \mathrm{COD}$ treated. 


\subsubsection{Nutrient Removal}

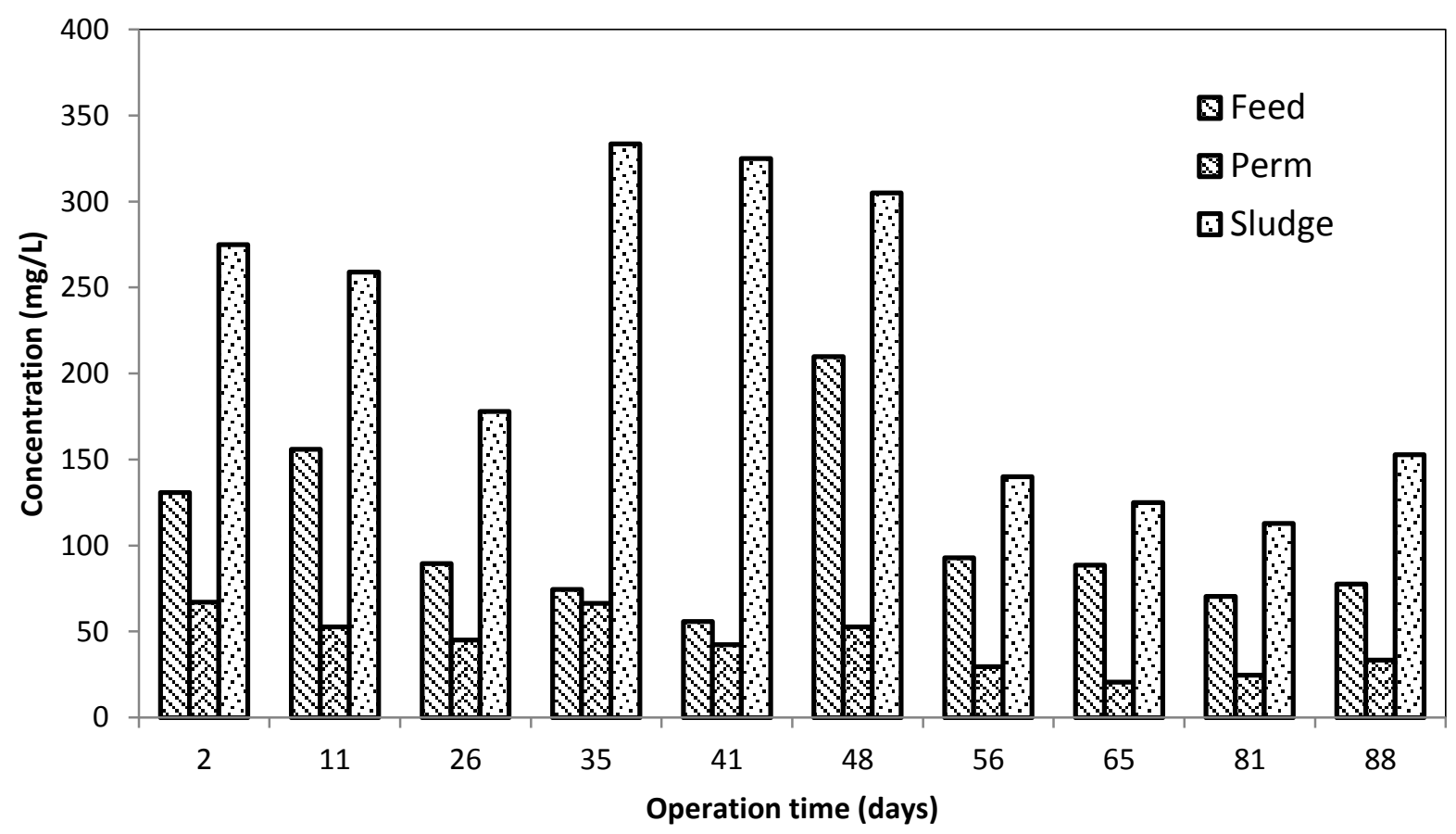

Figure 4-8 Total nitrogen in feed, permeate and sludge filtrate

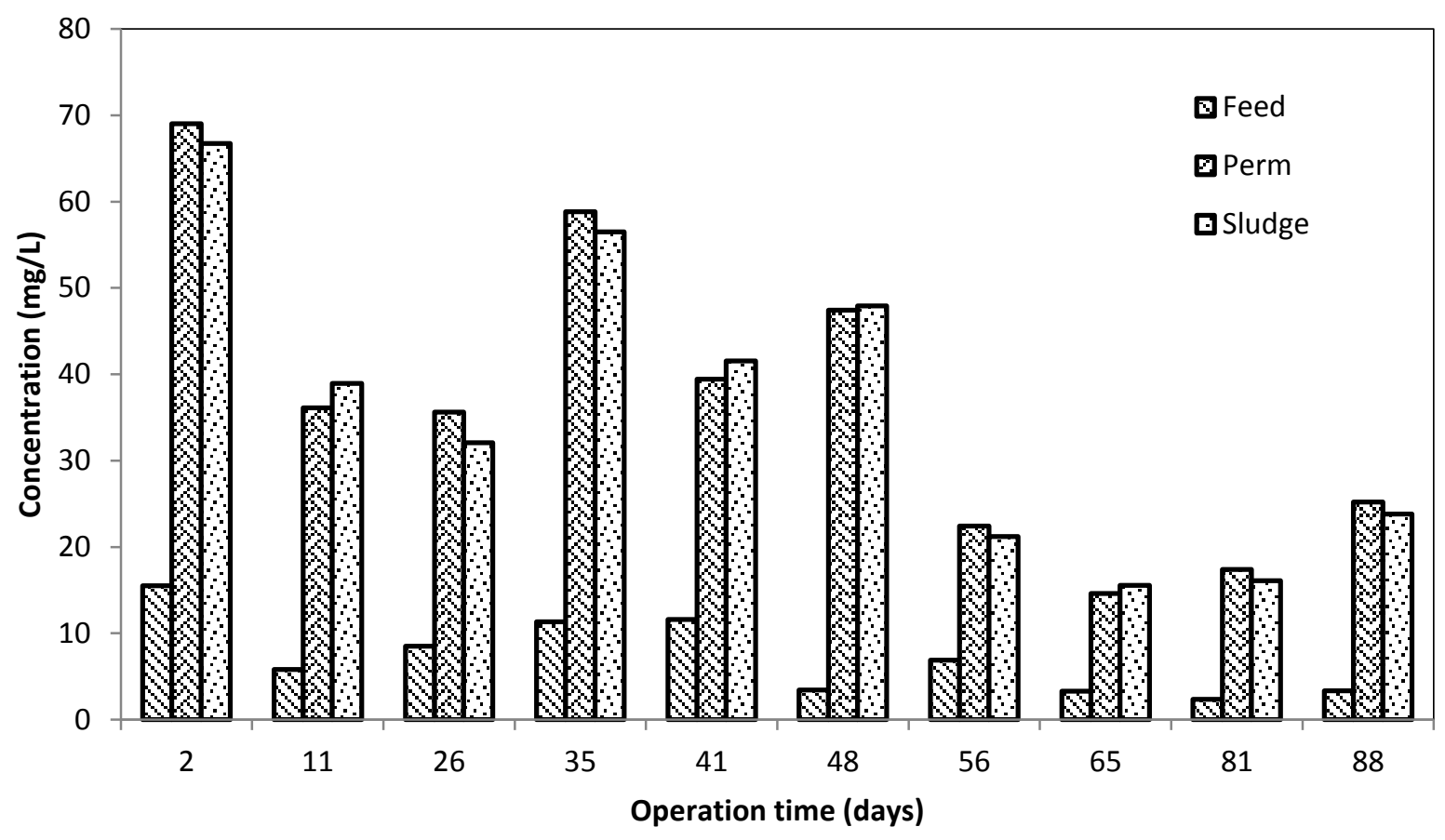

Figure 4-9 NH3-N in feed, permeate and sludge filtrate 
Figure 4-8 and Figure 4-9 show the total nitrogen and ammonia nitrogen in feed, permeate and mixed liquor filtrate. The total nitrogen in the effluent slightly fluctuates with the intake nitrogen from batch to batch, with an average of $43 \pm 10 \mathrm{mg} / \mathrm{L}$. The system had an overall nitrogen removal efficiency of $54 \pm 13 \%$. In contrast, the inorganic portion of nitrogen in feed wastewater was insignificant, with $7 \pm 3 \mathrm{mg} / \mathrm{L}$ ammonia nitrogen, roughly only $7 \pm 4 \%$ of the total nitrogen. The anaerobic digestion had then converted most organic nitrogen into ammonia, where $36 \pm 11 \mathrm{mg} / \mathrm{L} \mathrm{NH}_{3}-\mathrm{N}$ was found in both sludge filtrate and permeate due to the complete soluble of ammonia. The ammonia nitrogen made up $81 \pm 7 \%$ of the total nitrogen in the effluent. Organic nitrogen accumulation was observed in the mixed liquor, $185 \pm 45 \mathrm{mg} / \mathrm{L}$ was calculated from the difference in $\mathrm{TN}$ and $\mathrm{NH}_{3}-\mathrm{N}$. This can be further explained by the accumulation of protein EPS, which matches the mixed liquor colloidal protein concentration over the study period. 


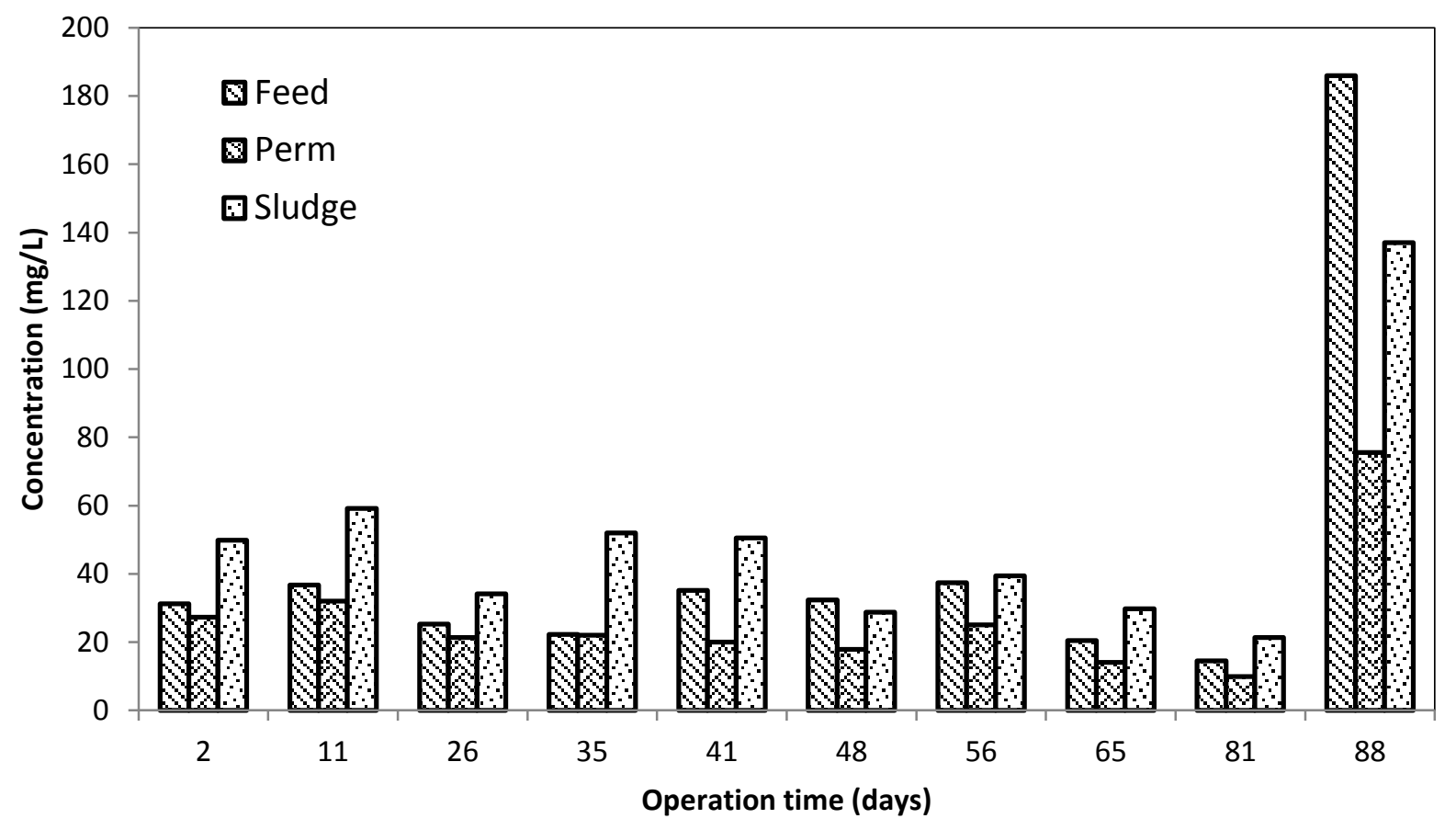

Figure 4-10 Total phosphorus in feed, permeate and sludge filtrate

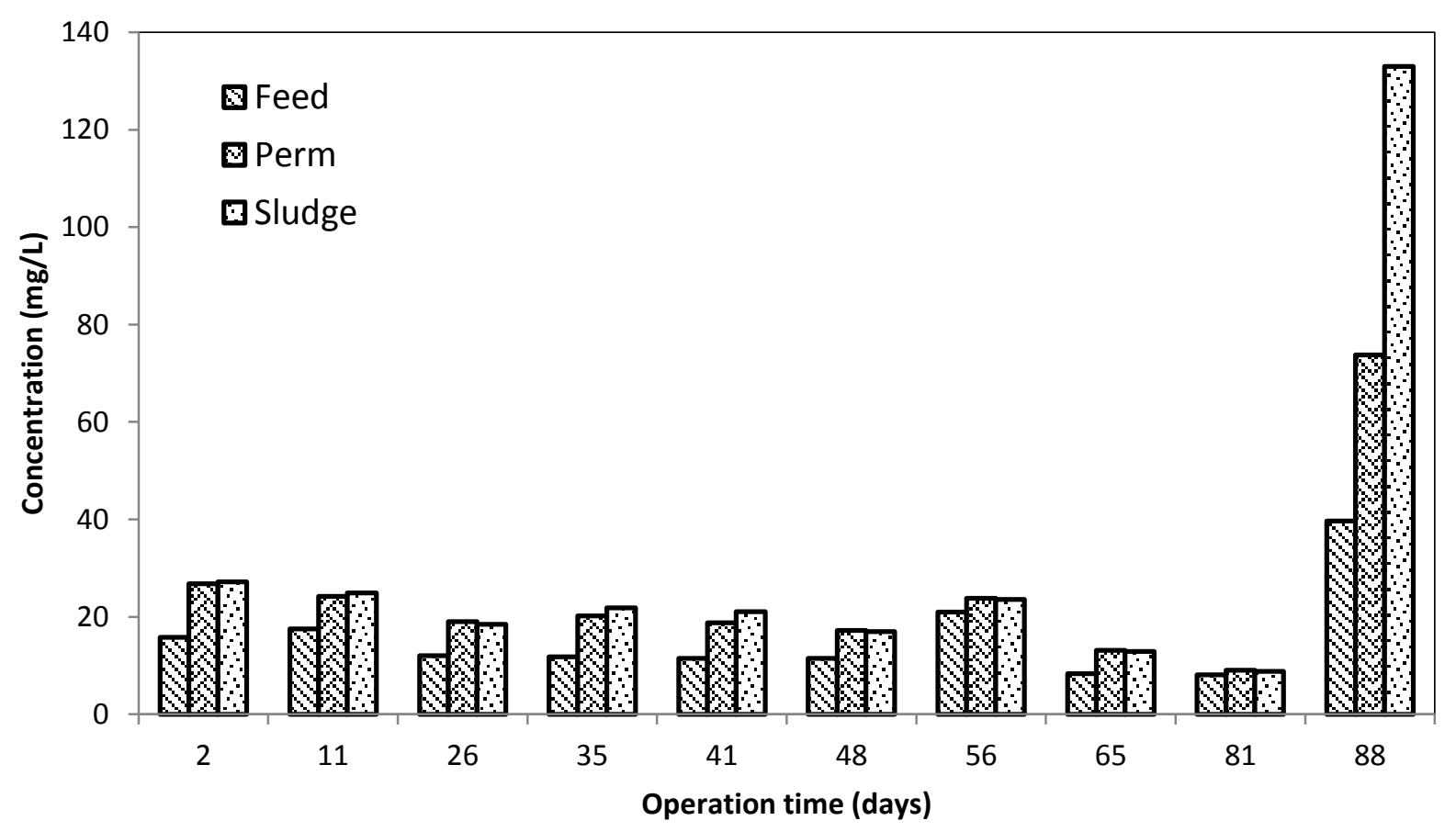

Figure 4-11 Orthophosphate-P in feed, permeate and sludge filtrate 
Total and orthophosphate-phosphors were tested throughout the study and shown in Figure 4-10 and Figure 4-11. Note that all phosphorus concentrations were significantly higher in day 88 , caused by the high concentration in the last batch of feed wastewater. The AnMBR system was capable of $28 \pm 11 \%$ total phosphorus removal, with observed total phosphorus of $28 \pm 5 \mathrm{mg} / \mathrm{L}$ in effluent. Similar to nitrogen, the inorganic phosphorus in feed solution was comparably low, about $44 \pm 7 \%$ total phosphors was orthophosphors. The anaerobic digestion has further converted organic phosphors into orthophosphors, resulting in effluent composed mainly of ortho-phosphors at $92 \pm 4 \%$. An accumulation of $21 \pm 5 \mathrm{mg} / \mathrm{L}$ organic phosphors was observed in biomass.

Based on the results, the AnMBR did not achieve an excellent nutrient removal as expected, as the effluent contains higher amounts of inorganic nitrogen and phosphorous. However, it presents opportunities for recovering nutrients from wastewater by reuse in lawn watering, where the presence of nutrients from effluents can be substituted for those from commercial fertilizer. 


\subsubsection{Biomass Characteristics}

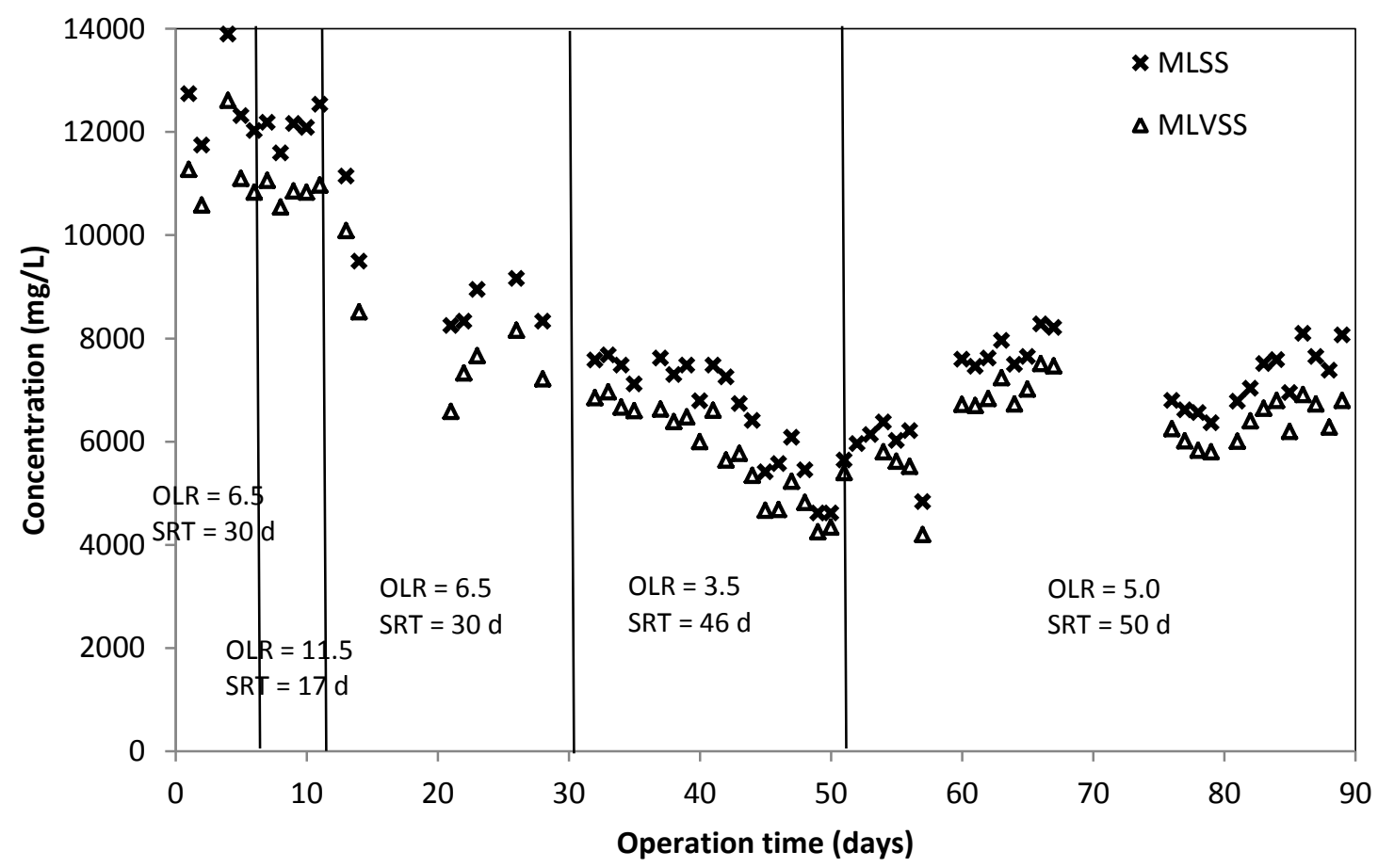

Figure 4-12 MLSS and MLVSS profile

Figure 4-12 shows the MLSS and MLVSS concentration during the different operation periods. The study started by using active anaerobic sludge inherited from the previous synthetic brewery wastewater study, with an initial MLSS and MLVSS concentration of $11800 \mathrm{mg} / \mathrm{L}$ and $10200 \mathrm{mg} / \mathrm{L}$, respectively. One of the research scopes was to investigate the system and membrane performance under low biomass concentrations. The target was to stabilize MLVSS around $7000 \mathrm{mg} / \mathrm{L}$ by adjusting daily sludge wasting. During the earlier stage, the biomass concentration was gradually decreased by having high sludge wasting operation. The average wasting for OLR 6.5 and $11.5 \mathrm{~kg} / \mathrm{m}^{3} /$ day operation period were $500 \mathrm{ml} /$ day and $900 \mathrm{ml} /$ day. The set target was achieved after the OLR 6.5 $\mathrm{kg} / \mathrm{m}^{3} /$ day operation on day 29 ; however, the stabilization failed. The biomass further 
decreased in the next 20 days, due to a combination of toxic influent wastewater on day 30 to 37 and low organic loading of $3.5 \mathrm{~kg} / \mathrm{m}^{3} /$ day. Excessive wasting of $325 \mathrm{ml} / \mathrm{day}$ on average was observed during day 30 to 50, corresponding to an average SRT of 46 days. On day 32, an immediate decline in MLVSS was observed followed by MLSS reduction in the next few days. The MLSS was found to be less sensitive to condition changes. The lowest MLSS and MLVSS observed were $4825 \mathrm{mg} / \mathrm{L}$ and $4250 \mathrm{mg} / \mathrm{L}$ before increased OLR to $5.0 \mathrm{~kg} \mathrm{COD} / \mathrm{m}^{3} /$ day.

During the final organic loading $5 \mathrm{~kg} / \mathrm{m}^{3} /$ day stage, sludge was wasted at $300 \pm 50$ $\mathrm{ml} / \mathrm{day}$, corresponding to SRT of 50 days. A stable biomass concentration was achieved at $7600 \pm 200 \mathrm{mg} / \mathrm{L}$ MLSS and $6700 \pm 200 \mathrm{mg} / \mathrm{L}$ MLVSS. The observed yield and specific growth were calculated to be $0.029 \pm 0.001 \mathrm{gVSS} / \mathrm{gCOD}$ and $0.022 \pm 0.001$

gVSS/gVSS/day. Both yield and specific growth values are comparably lower than the typical values on conventional anaerobic processes (Metcalf \& Eddy, 2002). Comparing to the earlier AnMBR study on synthetic wastewater, the biomass yield was identical but specific growth was found to be $25 \%$ lower. Over the entire study, a very high and stable VSS/TSS ratio of $0.86 \pm 0.04$ was observed, indicating very active biomass.

\subsubsection{Extracellular Polymeric Substances (EPSs) Characteristics}

Various literatures reported that the EPSs were the main contributor to membrane fouling in MBRs (Dereli et al., 2012a; Skouteris et al., 2012; Stuckey, 2012). EPS are polymeric substances produced by microorganisms, mainly consisting of protein, polysaccharides and humic acid (Laspidou and Rittmann, 2002). EPSs are released during cell metabolism as well as during starvation and stress as the cell metabolizes internal material and scavenges nutrients (Barker and Stuckey, 1999). Operating factors such as 
extended SRT and high organic loading rate can increase EPSs production (Stuckey, 2012). In this study, weekly analysis was done on both colloidal and soluble protein and polysaccharide in the bulk sludge, as well as the protein and polysaccharide in the membrane permeate. Figure 4-13 shows the polysaccharide concentration and Figure 4-14 shows the protein data in the mixed liquor and membrane permeate.

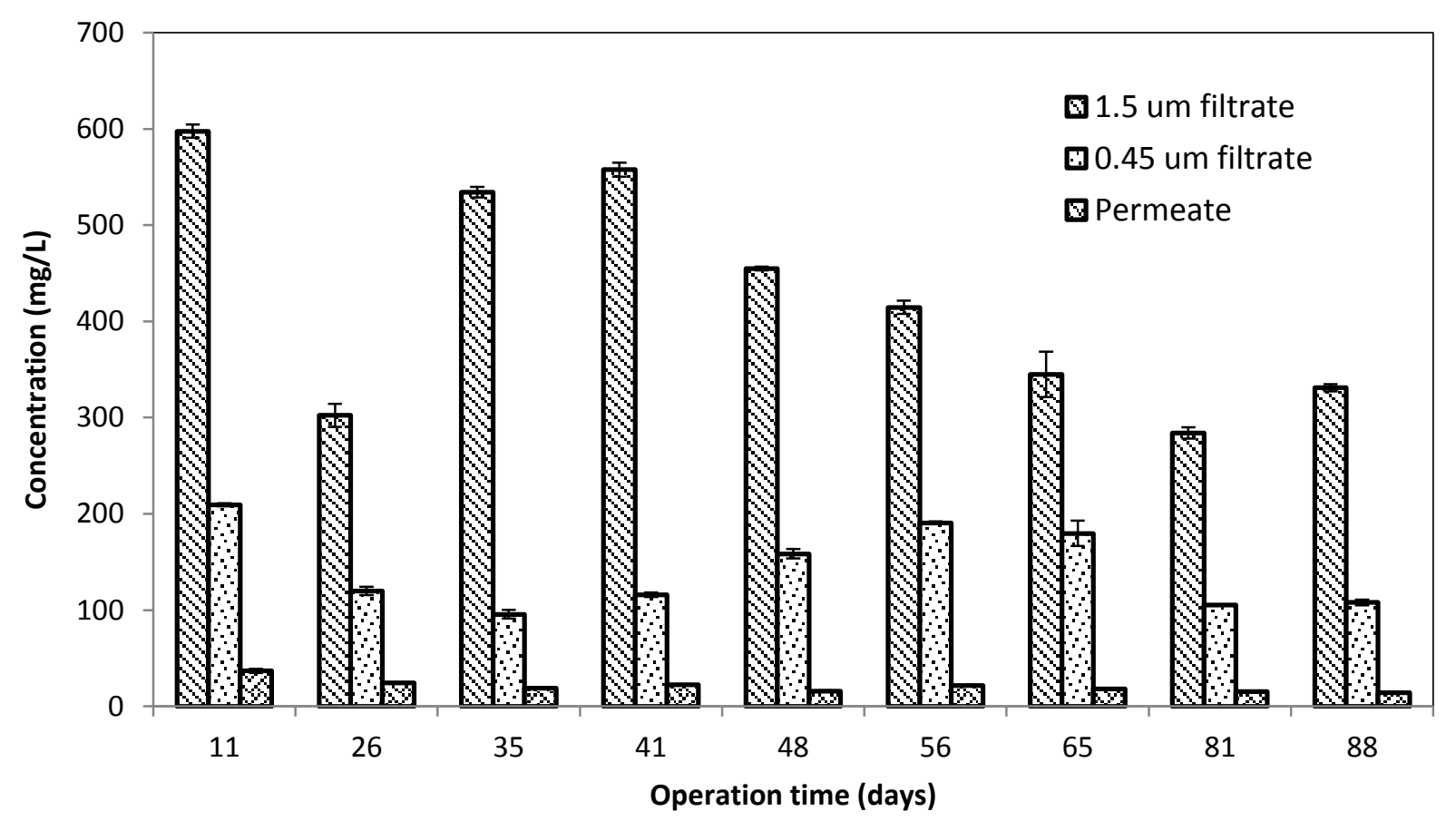

Figure 4-13 Polysaccharide in bulk sludge filtrate and permeate 


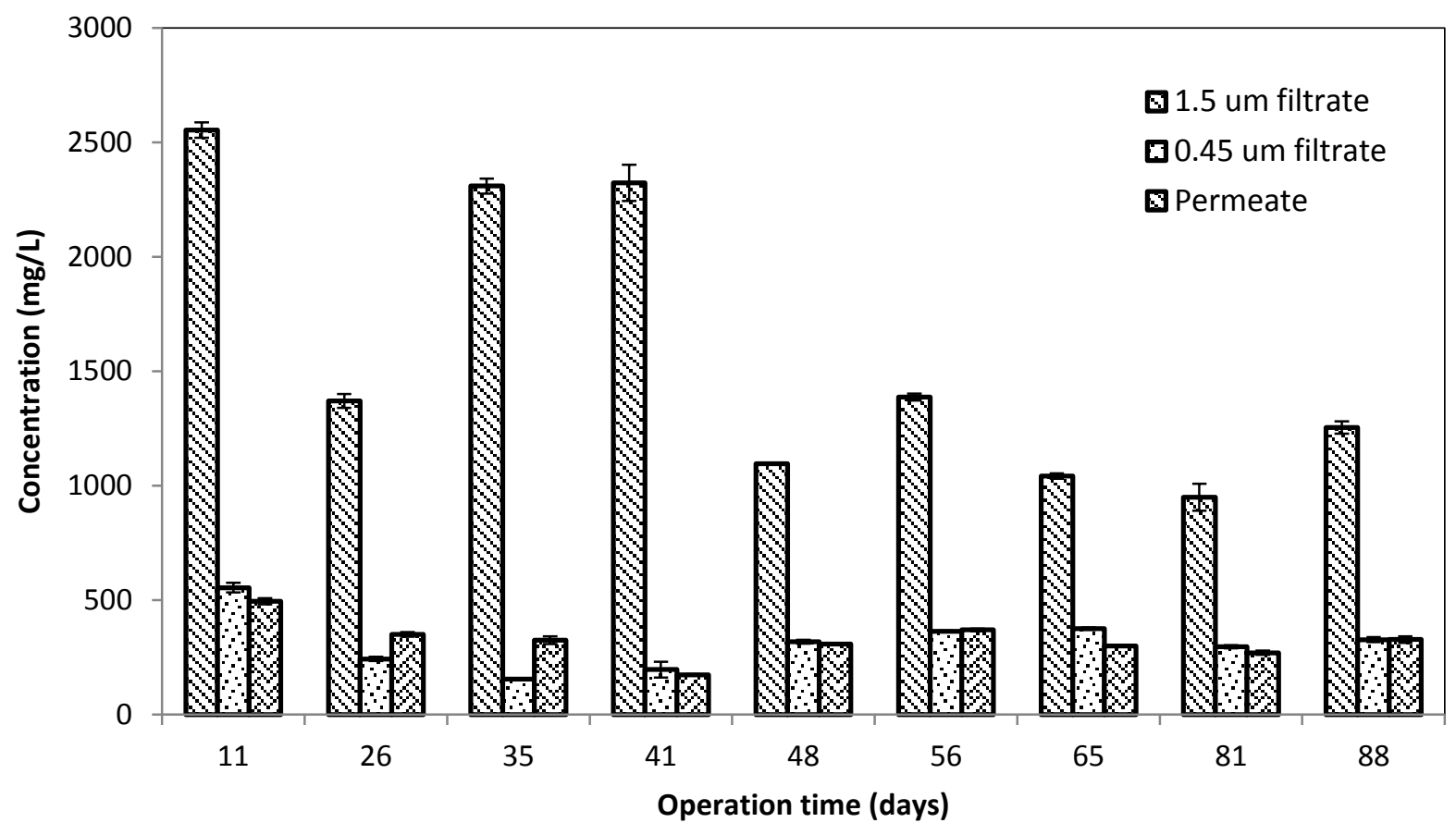

Figure 4-14 Protein in bulk sludge and permeate

High EPS concentrations were observed in both polysaccharide and protein during the earlier high organic loading (day 11 at $11.5 \mathrm{~kg} / \mathrm{m}^{3} /$ day), as well as after the toxic feeding during day 30 to 37 . The toxic substance stimulates the production of colloidal protein and polysaccharide in the bulk sludge, since only colloidal polysaccharide and protein increased while soluble substances were maintained. Further, high colloidal protein in mixed liquor explained the higher concentration in colloidal COD and organic nitrogen on day 35 and 41 which has been reported earlier. Aside from the high organic loading $11.5 \mathrm{~kg} / \mathrm{m}^{3} /$ day operation (on day 11 ) and intoxication period (on day 35 and 41 ), the EPSs in bulk sludge were relatively stable, but may display a decreasing tendency. The observation is different than the earlier synthetic wastewater study, where a rapid increasing tendency or a bulk accumulation of EPS was found. 
Overall, a very stable protein/polysaccharide ratio was found in the bulk sludge, with 3.7 \pm 0.4 in $1.5 \mu \mathrm{m}$ filtrate and $2.2 \pm 0.3$ in $0.45 \mu \mathrm{m}$ filtrate. Protein was dominated in permeate, having a high protein/polysaccharide ratio of $16.2 \pm 2.7$. Earlier research (Ince et al., 2000) also argued that the inert soluble COD in the effluent was mostly produced by the biomass and could not be removed even with the extended HRT. In this study, it was found that the soluble protein at $325 \pm 25 \mathrm{mg} / \mathrm{L}$ in permeate could not be further biodegraded by anaerobic digestion, which makes up the majority of the COD in effluent.
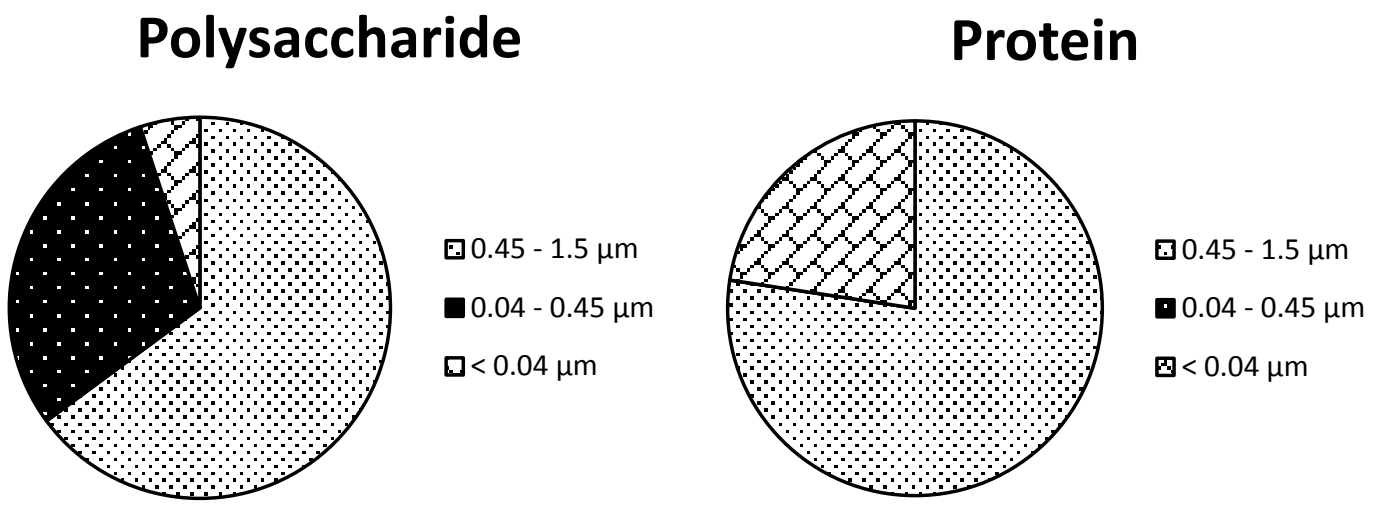

Figure 4-15 Polysaccharide and protein composition in mixed liquor

Based on the above results, polysaccharide and protein composition were analysed by rejection pore size, shown in Figure 4-15. The observation was comparable to the earlier study. The majority of polysaccharide in the bulk sludge were colloidal, while most of the soluble ones had particle sizes larger than $0.04 \mu \mathrm{m}$. Protein expressed a bimodal distribution, with a peak in the colloidal region and a peak in the small particle size $(<0.04 \mu \mathrm{m})$ region. The ultrafiltration membrane rejected $85 \pm 3 \%$ soluble polysaccharide, and there was no significant soluble protein being rejected by the membrane. 


\subsubsection{Membrane Filtration Performance}

Constant flux filtration at $8 \mathrm{LMH}$ with continuous biogas recirculation rate of 12 LPM was operated over the entire study, corresponding to a scouring rate of approximately $15.3 \mathrm{~m}^{3} / \mathrm{m}^{2} / \mathrm{hr}$, similar to the operation scouring at $17.6 \mathrm{~m}^{3} / \mathrm{m}^{2} / \mathrm{hr}$ in an earlier lab scale hollow fiber AnMBR operation study (Diez et al., 2012). Over the 90 day study period, the TMP was monitored, and average daily cycle TMP, as well as the determined critical fluxes are reported in Figure 4-16. Critical flux tests were performed weekly using the flux stepping method (Cho and Fane, 2002), by increasing the flux in a 15 min step-wise fashion while analysing the corresponding TMP. According to Le Clech et al. (2003), critical flux was determined as the corresponding flux where in a 10 minute duration, the observed TMP had increased by $0.1 \mathrm{kPa}$ or greater.

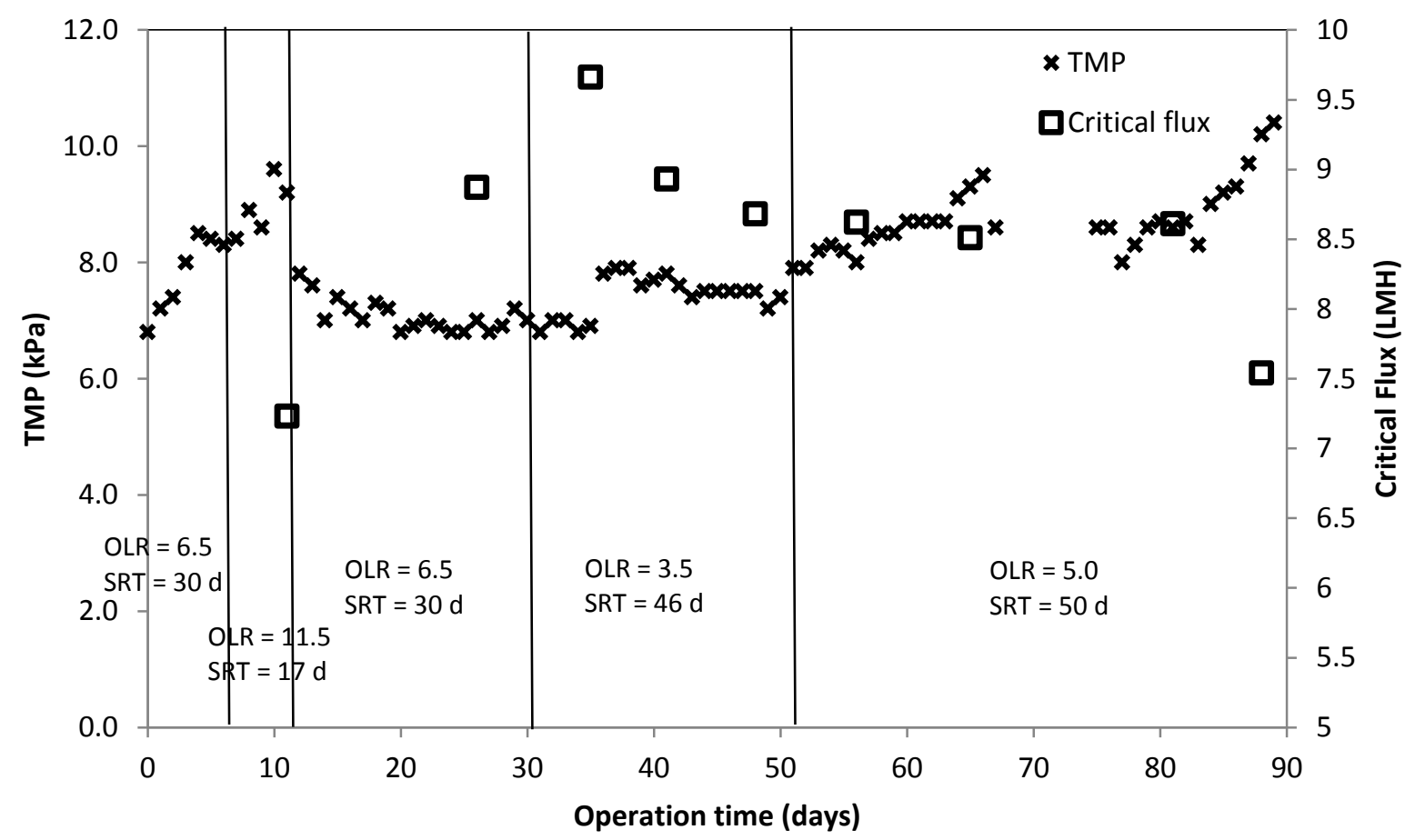

Figure 4-16 TMP profile and measured critical flux 
A rapid increase in TMP at a daily rate of $0.28 \mathrm{kPa}$ was observed in the first 11 days, when operating at OLR of $11.5 \mathrm{~kg} \mathrm{COD} / \mathrm{m}^{3} /$ day. The critical flux test conducted on day 11 showed that the operation flux was higher than the critical flux that was found at 7.2 LMH. The EPS measurement conducted on the same day showed that the protein and polysaccharide concentrations were $2550 \pm 35$ and $600 \pm 7 \mathrm{mg} / \mathrm{L}$ in $1.5 \mu \mathrm{m}$ sludge filtrate and $550 \pm 21$ and $210 \pm 2 \mathrm{mg} / \mathrm{L}$ in $0.45 \mu \mathrm{m}$ membrane filtrate, respectively.

Organic loading rate was then immediately adjusted to $6.5 \mathrm{~kg} / \mathrm{m}^{3} /$ day by diluting the wastewater, with the operation flux still maintained at $8 \mathrm{LMH}$. A sudden drop of $1.4 \mathrm{kPa}$ in TMP was observed on day 12 , followed by a gradual decrease over the next week, which stabilized at $6.9 \pm 0.1 \mathrm{kPa}$ from day 20 to 35 . A comparatively high critical flux was observed on day 35 , due to lower organic loading $\left(3.5 \mathrm{~kg} / \mathrm{m}^{3} /\right.$ day $)$ and lower observed EPS concentration in the mix liquor. It was noted that the weekly chemical cleaning-in-place (CIP) was skipped on day 35 after the critical flux test, which resulted in a TMP jump of $0.9 \mathrm{kPa}$ shown on day 36. A gradual decline in TMP was then witnessed after weekly CIP was back to schedule and it was maintained at $7.5 \pm 0.1 \mathrm{kPa}$ for the rest of $3.5 \mathrm{~kg} / \mathrm{m} 3 /$ day operation.

After switching to organic loading of $5.0 \mathrm{~kg} / \mathrm{m}^{3} /$ day, the operation TMP gradually increased and a slight drop in TMP was observed after each weekly CIP. With the weekly cleaning protocol, an operation TMP of $8.7 \pm 0.1 \mathrm{kPa}$ was perceived during the organic loading. The critical flux measured on day 88 was below the operation flux. Thus, a gradual increase in TMP was observed at the end of study period, suggesting that a recovery cleaning of the membrane was necessary. 
Over the 90 day study period, a TMP increase of $3.6 \mathrm{kPa}$ was observed without performing any recovery cleaning. A sustainable operation of $8 \mathrm{LMH}$ was achieved at organic loading of $3.5,5.0$ and $6.5 \mathrm{~kg} / \mathrm{m} 3 /$ day, with detected critical flux at $8.8 \pm 0.3$ LMH. Lower critical flux below 8 LMH was identified under high organic loading 11.5 $\mathrm{kg} / \mathrm{m}^{3} /$ day operation, which caused a significant increase on operation TMP over a short time frame, thus a sustainable operation at $8 \mathrm{LMH}$ could not be maintained. The study suggests the AnMBR should be running at an organic loading less than $6.5 \mathrm{~kg} / \mathrm{m}^{3} / \mathrm{day}$ and more importantly, a lower operation flux at $7 \mathrm{LMH}$ is recommended to achieve long term sustainable operation and extend membrane lifetime. Aside from the design flux and OLR, a weekly CIP protocol is essential to control the long term membrane fouling.
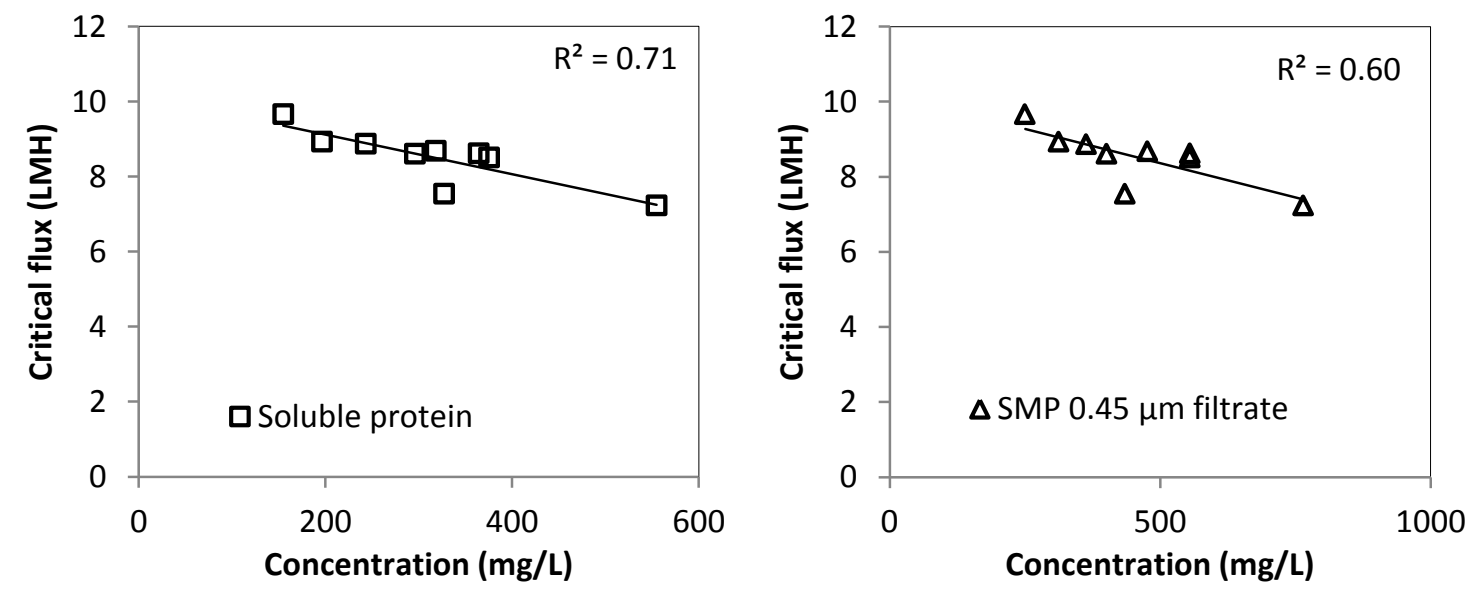

Figure 4-17 Relationship between critical flux and EPS in bulk sludge

In comparison to the earlier synthetic wastewater study, significantly higher concentrations of microbial products were detected in this study. Colloidal polysaccharide and protein greater than 285 and $950 \mathrm{mg} / \mathrm{L}$ with soluble polysaccharide and protein no less than 95 and $155 \mathrm{mg} / \mathrm{L}$ were detected, respectively. Combining critical flux data and the EPS concentration in bulk sludge, a moderate correlation was found 
between the critical flux and EPS or more precisely soluble protein in bulk sludge, shown in Figure 4-17. A steady decrease in the determined critical flux was affected by the increase of soluble portion of microbial products. The earlier synthetic wastewater study found the critical flux was more sensitive to EPS in bulk sludge with colloidal polysaccharide and protein concentration less $200 \mathrm{mg} / \mathrm{L}$ and $800 \mathrm{mg} / \mathrm{L}$; however, it does not apply to real brewery wastewater.

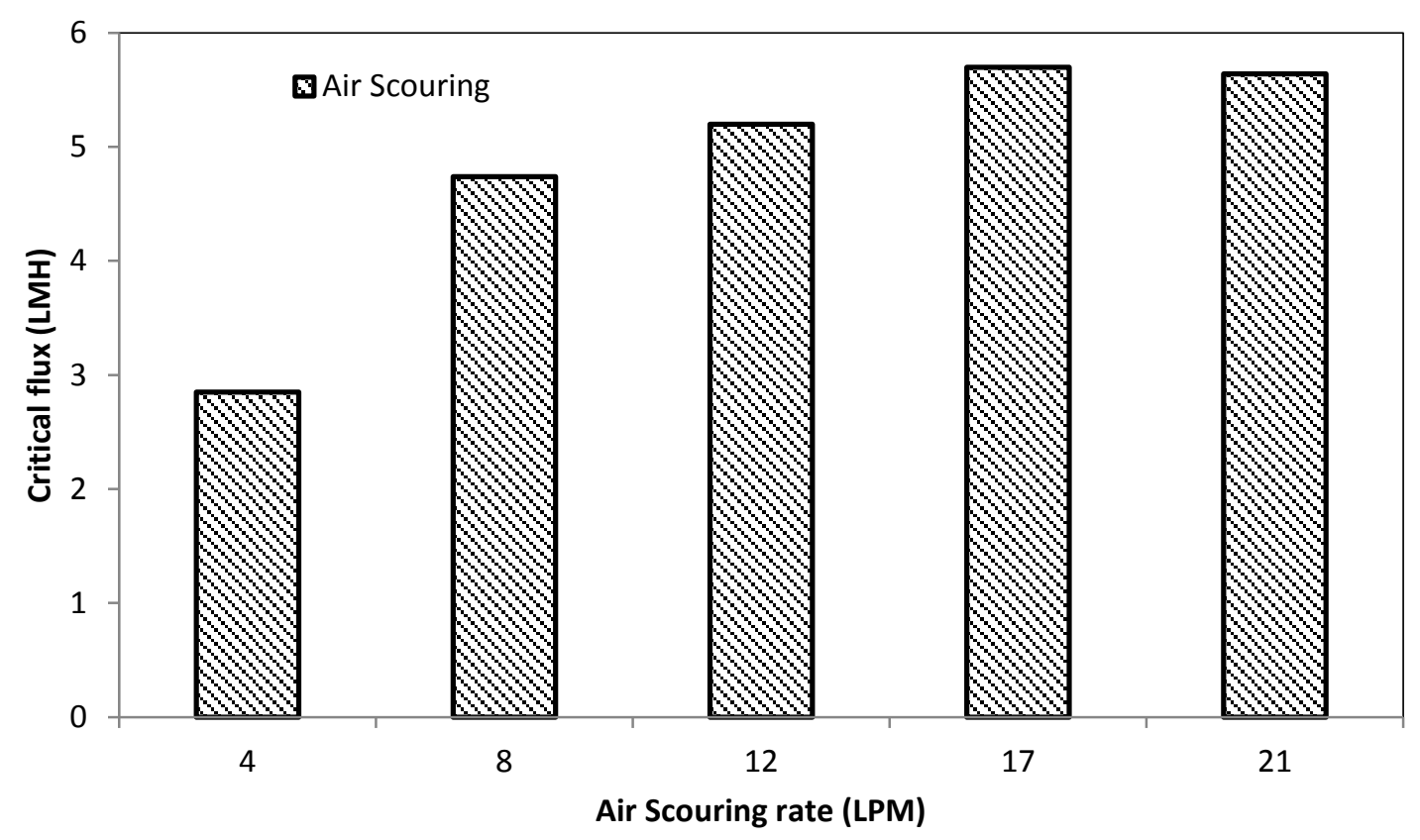

Figure 4-18 Effect of gas scouring on critical flux

At the end of the study period, critical flux tests were conducted over different air scouring rates. Five biogas recirculation rates were tested, corresponding to normalized scouring rates of 5.0, 10.2, 15.7, 21.1 and $26.5 \mathrm{~m}^{3} / \mathrm{m}^{2} / \mathrm{hr}$. The results in Figure 4-18 indicated that the critical flux was greatly affected by the gas scouring intensity, where the critical flux increased when the gas scouring rate was increased and the difference was smaller as scouring rate got larger. Eventually the difference is insignificant after the 
gas scouring rate increased to 17 LPM or above, suggesting after this point, a higher gas scouring rate would not reduce membrane fouling any further.

\subsection{CONCLUSION}

In this study, the efficacy of the submerged AnMBR technology was demonstrated over high organic strength wastewater from a local craft brewery. Due to the variance of influent wastewater strength over the batch brewing processes, the AnMBR unit was subjected to operation with highly variable organic loading from 3.5 to $11.5 \mathrm{~kg}$ $\mathrm{COD} / \mathrm{m}^{3} /$ day. Overall, the system achieved over $98 \% \mathrm{COD}, 54 \% \mathrm{TN}$ and $28 \% \mathrm{TP}$ removal efficiency. Effluent COD was slightly increased with the organic loading, where observed permeate COD was at $149 \pm 7,172 \pm 15$ and $268 \pm 21 \mathrm{mg} / \mathrm{L}$ for OLR of 5.0, 6.5 and $11.5 \mathrm{~kg} / \mathrm{m}^{3} /$ day, respectively. The permeate contained mostly non-biodegradable EPS, mainly soluble protein, as the ultrafiltration membrane rejected $85 \%$ soluble polysaccharide with no significant rejection on soluble protein. A favorable $\mathrm{pH}$ and total alkalinity condition was maintained with an average dosage of $0.37 \mathrm{~kg} \mathrm{NaHCO} / \mathrm{m}^{3}$ influent. The methane yield was found to be very stable at $0.31 \mathrm{~m}^{3} \mathrm{CH}_{4} / \mathrm{kg} \mathrm{COD}\left(35^{0} \mathrm{C}\right)$. In comparison to the earlier synthetic wastewater study, significantly higher concentration of EPS were found in the mix liquor. Moreover, a moderate correlation was found between the critical flux and soluble protein concentration. An overall TMP increase of $3.6 \mathrm{kPa}$ was observed over the 90 days period without any recovery cleaning. The study recommends running high strength brewery wastewater AnMBR on organic loading under $6.5 \mathrm{~kg} / \mathrm{m}^{3} /$ day with operation flux at $7 \mathrm{LMH}$, coupled with a weekly CIP protocol to maintain long term sustainable operation and extend membrane lifetime. 


\subsection{ACKNOWLEDGEMENT}

The authors thank Ontario Ministry of Agriculture, Food and Rural Affairs (OMAFRA) (NO 200385), Canada Foundation for Innovation (CFI) (NO. 28061), and GE Water and

Process Technologies, and Ontario Centers of Excellence (CR-SW-11384-12) for the support on this research. 


\section{CHAPTER 5 - CONCLUSION AND RECOMMENDATIONS}

\subsection{OVERALL DISCUSSION AND CONCLUSION}

Throughout this research, the efficacy of the submerged AnMBR technology on wastewater treatment was demonstrated over the high organic strength wastewater from the brewery industry. The AnMBR unit was subjected to a total of 230 days continuous operation, undergoing precisely controlled OLRs (2-10 kg COD/m $3 /$ day) with synthetic wastewater and uncontrolled OLRs (observed OLR of $3.5-11.5 \mathrm{~kg} \mathrm{COD} / \mathrm{m}^{3} /$ day) operation through feeding with local micro-brewery wastewater having high variability in strength and characteristics.

The system achieved stable operation with no acidification was observed. Overall, the AnMBR achieved an excellent organic reduction at over 98\% COD removal efficiency. In spite of the variability in feed strength and OLR, the AnMBR was capable of producing high quality effluent with COD concentrations lower than $300 \mathrm{mg} / \mathrm{L}$ throughout the study. The effluent COD concentration was a function of the OLR and found to be significantly higher in the real brewery wastewater operation. At OLRs of 5 $\mathrm{kg} \mathrm{COD} / \mathrm{m}^{3} /$ day, the COD concentrations in effluent under synthetic and real brewery wastewater were $52 \pm 2$ and $149 \pm 7 \mathrm{mg} / \mathrm{L}$, respectively. The study found that the effluent contained mostly non-biodegradable soluble substances, since the effluent BOD concentration remained below $40 \mathrm{mg} / \mathrm{L}$ at all OLRs.

The EPS analysis further supported this argument. The membrane permeate contains mostly non-biodegradable protein which was likely being produced during cell metabolism. Significantly higher EPS concentrations were observed in both sludge 
supernatant and membrane permeate while operating AnMBR on real brewery wastewater. During the real wastewater operation at OLR of $5 \mathrm{~kg} \mathrm{COD} / \mathrm{m}^{3} / \mathrm{day}$, the EPS concentrations observed in $1.5 \mu \mathrm{m}$ sludge filtrate and membrane permeate were $1500 \pm$ 240 and $335 \pm 45 \mathrm{mg} / \mathrm{L}$, compared to $185 \pm 15$ and $80 \pm 10 \mathrm{mg} / \mathrm{L}$ that were found in the synthetic wastewater study at the corresponding OLR.

The weekly EPS analysis also suggested that the UF membrane was capable of $85-95 \%$ soluble polysaccharide rejection but no significant soluble protein rejection. The majority of polysaccharide in the bulk sludge was colloidal and most of the soluble matter has particle sizes larger than $0.04 \mu \mathrm{m}$. The protein EPSs were expressed in a bimodal distribution, with a peak in the colloidal region and a peak in the small particle size $(<0.04 \mu \mathrm{m})$ region. Moreover, a moderate correlation was found between the critical flux and EPS concentration in bulk sludge. The correlation was more sensitive when polysaccharide and protein concentration were below $200 \mathrm{mg} / \mathrm{L}$ and $800 \mathrm{mg} / \mathrm{L}$; however, it did not apply to real brewery wastewater operation, as the EPS concentrations were found to be much higher.

Overall, the AnMBR system achieved an excellent COD removal at all tested OLRs, produced high quality effluent free of solid and demonstrated great energy recovery, with stable methane yield over $0.31 \mathrm{~m}^{3} \mathrm{CH}_{4} / \mathrm{kg}$ COD at $35{ }^{0} \mathrm{C}$. The study found the major limitation was the low membrane filtration flux. Low critical fluxes were observed under high organic loading. An average critical flux of $8.6 \pm 0.1$ was observed under real brewery wastewater operation at an OLR of $5 \mathrm{~kg} / \mathrm{m}^{3} /$ day. To achieve full capacity in the anaerobic digestion compartment, the AnMBR should have more membrane installed to increase the operation OLR. However, this would largely increase the capital cost. 
In evaluating the system performance and taking the membrane cost into consideration, this study suggests running AnMBRs on high strength brewery wastewater at an OLR under $6.5 \mathrm{~kg} / \mathrm{m}^{3} /$ day with an operation flux of $7 \mathrm{LMH}$. A weekly CIP and semi-annual recovery cleaning protocol is recommended to maintain long term sustainable operation and extend membrane lifetime.

\subsection{RECOMMENDATIONS}

The following recommendations can be made based on this research,

1. The membrane module used in this study was at a different initial condition between the two operations. Thus, it is recommended that recovery cleaning should be conducted prior to each operation condition. With the membrane being restored to similar conditions, long term fouling rate can be easily compared.

2. Membrane autopsies should be conducted at the end of each operation; so that foulants can be directly characterized.

3. To better evaluate irreversible membrane fouling, more work is needed to characterize the EPS in the mixed liquor and membrane permeate.

4. A comprehensive GC-TCD analysis is strongly recommended to test the biogas composition at different operation phase. With more frequent biogas composition, methane yield at different OLRs or MLSS can be further investigated. Further, $\mathrm{H}_{2} \mathrm{~S}$ concentrations should be measured, creating strategy for biogas utilization.

5. The study found that the filterability of the sludge is highly dependent on the concentration of colloidal and extracellular polymeric substances, which increased with OLR. Thus, the OLR was limited by the filterability of the suspended biomass. Hybrid reactor configurations should be considered in future 
research. With a combination of granules, biofilm or presence of GAC, the OLR can be potentially increased with minor decreases in filterability.

6. Higher operation fluxes require more frequent membrane cleaning; thus decreasing the membrane lifetime and increasing membrane replacement cost. Contrarily, the lower operation flux requires more module, which increases the capital cost. A systematic cost balance should be conducted between the initial installation and replacement membrane cost. Design flux and cleaning frequency can be recommended based on the results. 


\section{CHAPTER 6 - REFERENCES}

Abdurahman, N.H., Rosli, Y.M., Azhari, N.H., 2011. Development of a membrane anaerobic system (MAS) for palm oil mill effluent (POME) treatment. Desalination 266, 208-212. doi:10.1016/j.desal.2010.08.028

APHA-AWWA-WEF, 2005. Standard Methods for the Examination of Water \& Wastewater. American Public Health Association.

Baker, R.W., 2002. Membrane Technology, in: Encyclopedia of Polymer Science and Technology. John Wiley \& Sons, Inc.

Barker, D.J., Stuckey, D.C., 1999. A review of extracellular polymeric substances (EPS) in wastewater treatment systems. Water Res. 33, 3063-3082. doi:10.1016/S00431354(99)00022-6

Bradford, M.M., 1976. A rapid and sensitive method for the quantitation of microgram quantities of protein utilizing the principle of protein-dye binding. Anal. Biochem. 72, 248-254. doi:10.1016/0003-2697(76)90527-3

Braeken, L., Van der Bruggen, B., Vandecasteele, C., 2004. Regeneration of brewery waste water using nanofiltration. Water Res. 38, 3075-3082. doi:10.1016/j.watres.2004.03.028

Breitner, J., 2013. Pulse aeration for immersed membranes. WO2013106191 A1.

Brewers Association, n.d. Water and Wastewater: Treatment/Volume Reduction Manual.

Briggs, D.E., Brookes, P.A., Stevens, R., Boulton, C.A., 2004. Brewing: Science and Practice, 1 edition. ed. Woodhead Publishing, Boca Raton : Cambridge, England.

Brito, A.G., Peixoto, J., Oliveira, J.M., Oliveira, J.A., Costa, C., Nogueira, R., Rodrigues, A., 2007. Brewery and Winery Wastewater Treatment: Some Focal Points of Design and Operation, in: Oreopoulou, V., Russ, W. (Eds.), Utilization of ByProducts and Treatment of Waste in the Food Industry. Springer US, pp. 109-131.

Brockmann, M., Seyfried, C.F., 1996. Sludge activity and cross-flow microfiltration - A non-beneficial relationship. Water Sci. Technol., Water Quality International '96 Selected Proceedings of the 18th Biennial Conference of the International Association on Water Quality 34, 205-213. doi:10.1016/S0273-1223(96)00806-2

Buer, T., Cumin, J., 2010. MBR module design and operation. Desalination 250, 10731077. doi:10.1016/j.desal.2009.09.111

Bureau, A. and A.-F.C. of C.A. and A.-F.C.F.V.C., 2009. The Canadian Brewery Industry (report). 
Chang, I., Le Clech, P., Jefferson, B., Judd, S., 2002. Membrane Fouling in Membrane Bioreactors for Wastewater Treatment. J. Environ. Eng. 128, 1018-1029. doi:10.1061/(ASCE)0733-9372(2002)128:11(1018)

Chang, S., 2014. Anaerobic Membrane Bioreactors (AnMBR) for Wastewater Treatment. Adv. Chem. Eng. Sci. 04, 56-61. doi:10.4236/aces.2014.41008

Cho, B.D., Fane, A.G., 2002. Fouling transients in nominally sub-critical flux operation of a membrane bioreactor. J. Membr. Sci. 209, 391-403. doi:10.1016/S03767388(02)00321-6

Choo, K.-H., Lee, C.-H., 1996. Membrane fouling mechanisms in the membrane-coupled anaerobic bioreactor. Water Res. 30, 1771-1780. doi:10.1016/00431354(96)00053-X

Christian, S., Grant, S., Wilson, D., McCarthy, P., Mills, D., Kolakowski, M., 2010. The First Two Years of Full-Scale Anaerobic Membrane Bioreactor (Anmbr) Operation Treating a High Strength Industrial Wastewater at Kens Foods Inc. Proc. Water Environ. Fed. 2010, 4019-4033. doi:10.2175/193864710798182231

Cote, P., Alam, Z., Penny, J., 2012. Hollow fiber membrane life in membrane bioreactors (MBR). Desalination 288, 145-151. doi:10.1016/j.desal.2011.12.026

Cote, P., Janson, A., Rabie, H., Singh, M., 2000. Cyclic aeration system for submerged membrane modules. WO2000021890 A1.

Cote, P., Thompson, D., 2000. Wastewater treatment using membranes: the North American experience [WWW Document]. URL http://www.iwaponline.com/wst/04110/wst041100209.htm (accessed 11.10.14).

David Hufnagel, 2014. Anaerobic Membrane Bioreactor for High-Strength Wastewater Treatment. University of Guelph.

Dereli, R.K., Ersahin, M.E., Ozgun, H., Ozturk, I., Jeison, D., van der Zee, F., van Lier, J.B., 2012a. Potentials of anaerobic membrane bioreactors to overcome treatment limitations induced by industrial wastewaters. Bioresour. Technol., Membrane Bioreactors (MBRs): State-of-Art and Future 122, 160-170. doi:10.1016/j.biortech.2012.05.139

Dereli, R.K., Urban, D.R., Heffernan, B., Jordan, J.A., Ewing, J., Rosenberger, G.T., Dunaev, T.I., 2012b. Performance evaluation of a pilot-scale anaerobic membrane bioreactor (AnMBR) treating ethanol thin stillage. Environ. Technol. 33, 15111516. doi:10.1080/09593330.2012.665491

Diez, V., Ramos, C., Cabezas, J.L., 2012. Treating wastewater with high oil and grease content using an Anaerobic Membrane Bioreactor (AnMBR). Filtration and cleaning assays. Water Sci. Technol. 65, 1847. doi:10.2166/wst.2012.852 
Driessen, W., Verejiken, T., 2003. Recent developments in biological treatment of brewery effluent, in: Recent Developments in Biological Treatment of Brewery Effluent. Presented at the The Institute and Guild of Brewing Convention, Livingstone, Zambia.

DuBois, M., Gilles, K.A., Hamilton, J.K., Rebers, P.A., Smith, F., 1956. Colorimetric Method for Determination of Sugars and Related Substances. Anal. Chem. 28, 350-356. doi:10.1021/ac60111a017

Ersu, C.B., Ong, S.K., 2008. Treatment of Wastewater Containing Phenol Using a Tubular Ceramic Membrane Bioreactor. Environ. Technol. 29, 225-234. doi:10.1080/09593330802029012

Fakhru'l-Razi, A., 1994. Ultrafiltration membrane separation for anaerobic wastewater treatment [WWW Document]. URL http://www.iwaponline.com/wst/03012/wst030120321.htm (accessed 11.11.14).

Fang, H., Guohua, L., Jinfu, Z., Bute, C., Guowei, G., 1990. Treatment of Brewery Effluent by UASB Process. J. Environ. Eng. 116, 454-460. doi:10.1061/(ASCE)0733-9372(1990)116:3(454)

Federation, W.E., 2004. Financing and Charges for Wastewater Systems WEF MOP 27: WEF Manual of Practice No. 27, 1 edition. ed. McGraw-Hill Professional, New York.

Fuchs, W., Binder, H., Mavrias, G., Braun, R., 2003. Anaerobic treatment of wastewater with high organic content using a stirred tank reactor coupled with a membrane filtration unit. Water Res. 37, 902-908.

Grethlein, H.E., 1978. Anaerobic Digestion and Membrane Separation of Domestic Wastewater. J. Water Pollut. Control Fed. 50, 754-763.

HACH, 2008. Water Analysis Handbook, 5th ed. HACH Company, Loveland, Colorado, U.S.A.

Hai, F.I., Yamamoto, K., Lee, C.-H., 2013. Membrane Biological Reactors: Theory, Modeling, Design, Management and Applications to Wastewater Reuse. IWA Publishing.

He, Y., Xu, P., Li, C., Zhang, B., 2005. High-concentration food wastewater treatment by an anaerobic membrane bioreactor. Water Res. 39, 4110-4118. doi:10.1016/j.watres.2005.07.030

Ince, B.K., Ince, O., Anderson, G.K., Arayici, S., 2001. Assessment of Biogas use as an Energy Source from Anaerobic Digestion of Brewery Wastewater. Water. Air. Soil Pollut. 126, 239-251. doi:10.1023/A:1005236731131 
Ince, B.K., Ince, O., Sallis, P.J., Anderson, G.K., 2000. Inert COD production in a membrane anaerobic reactor treating brewery wastewater. Water Res. 34, 39433948. doi:10.1016/S0043-1354(00)00170-6

Ince, O., 1998. Experimental Determination of the Inert Soluble COD Fraction of a Brewery Wastewater under Anaerobic Conditions 19, 437-442.

Ince, O., Anderson, G.K., Kasapgil, B., 1993. Improvement in performance of an anaerobic contact digester using a crossflow ultrafiltration membrane technique for brewery wastewater treatment :: Engineering Technical Reports Collection, Purdue University. Presented at the 48th Purdue Industrial Waste Conference, Purdue University, West Lafayette, Indiana, U.S.A.

Kanai, M., Ferre, V., Wakahara, S., Yamamoto, T., Moro, M., 2010. A novel combination of methane fermentation and MBR - Kubota Submerged Anaerobic Membrane Bioreactor process. Desalination 250, 964-967. doi:10.1016/j.desal.2009.09.082

Kang, I.-J., Yoon, S.-H., Lee, C.-H., 2002. Comparison of the filtration characteristics of organic and inorganic membranes in a membrane-coupled anaerobic bioreactor. Water Res. 36, 1803-1813. doi:10.1016/S0043-1354(01)00388-8

Kim, M.-S., Lee, D.-Y., Kim, D.-H., 2011. Continuous hydrogen production from tofu processing waste using anaerobic mixed microflora under thermophilic conditions. Int. J. Hydrog. Energy, 4th Asian Bio-Hydrogen Symposium 36, 8712-8718. doi:10.1016/j.ijhydene.2010.06.040

Klijnhout, A.F., Eerde, P.V., 1986. Some Characteristics of Brewery Effluent. J. Inst. Brew. 92, 426-434. doi:10.1002/j.2050-0416.1986.tb04435.x

Laspidou, C.S., Rittmann, B.E., 2002. A unified theory for extracellular polymeric substances, extracellular polymeric substances, and active and inert biomass. Water Res. 36, 2711-2720. doi:10.1016/S0043-1354(01)00413-4

Le-Clech, P., Chen, V., Fane, T.A.G., 2006. Fouling in membrane bioreactors used in wastewater treatment. J. Membr. Sci. 284, 17-53. doi:10.1016/j.memsci.2006.08.019

Le Clech, P., Jefferson, B., Chang, I.S., Judd, S.J., 2003. Critical flux determination by the flux-step method in a submerged membrane bioreactor. J. Membr. Sci. 227, 81-93. doi:10.1016/j.memsci.2003.07.021

Lettinga, G., 2011. The Route of Anaerobic Waste (Water) Treatment toward Global Acceptance.

Liao, B.-Q., Kraemer, J.T., Bagley, D.M., 2006. Anaerobic Membrane Bioreactors: Applications and Research Directions. Crit. Rev. Environ. Sci. Technol. 36, 489530. doi:10.1080/10643380600678146 
Lin, H., Chen, J., Wang, F., Ding, L., Hong, H., 2011. Efficacy evaluation of submerged anaerobic membrane bioreactor for municipal secondary wastewater treatment. Desalination 280, 120-126. doi:10.1016/j.desal.2011.06.058

Lin, H.J., Xie, K., Mahendran, B., Bagley, D.M., Leung, K.T., Liss, S.N., Liao, B.Q., 2009. Sludge properties and their effects on membrane fouling in submerged anaerobic membrane bioreactors (SAnMBRs). Water Res. 43, 3827-3837. doi:10.1016/j.watres.2009.05.025

Lin, H., Peng, W., Zhang, M., Chen, J., Hong, H., Zhang, Y., 2013. A review on anaerobic membrane bioreactors: Applications, membrane fouling and future perspectives. Desalination 314, 169-188. doi:10.1016/j.desal.2013.01.019

MEDEI, 2012. Ontario Microbreweries Thriving. Ont. Newsroom.

Metcalf \& Eddy, 2002. Wastewater Engineering: Treatment and Reuse. McGraw-Hill Education.

Ministry of the Environment, 1998. The proposed 1998 Model Sewer Use By-law.

Natural Resources Canada, 2012. Guide to energy efficiency opportunities in the Canadian Brewing Industry.

Parawira, W., Kudita, I., Nyandoroh, M.G., Zvauya, R., 2005. A study of industrial anaerobic treatment of opaque beer brewery wastewater in a tropical climate using a full-scale UASB reactor seeded with activated sludge. Process Biochem. 40, 593-599. doi:10.1016/j.procbio.2004.01.036

Rajeshwari, K.V., Balakrishnan, M., Kansal, A., Lata, K., Kishore, V.V.N., 2000. Stateof-the-art of anaerobic digestion technology for industrial wastewater treatment. Renew. Sustain. Energy Rev. 4, 135-156. doi:10.1016/S1364-0321(99)00014-3

Rao, A.G., Reddy, T.S.K., Prakash, S.S., Vanajakshi, J., Joseph, J., Sarma, P.N., 2007. $\mathrm{pH}$ regulation of alkaline wastewater with carbon dioxide: A case study of treatment of brewery wastewater in UASB reactor coupled with absorber. Bioresour. Technol. 98, 2131-2136. doi:10.1016/j.biortech.2006.08.011

Saddoud, A., Hassaïri, I., Sayadi, S., 2007. Anaerobic membrane reactor with phase separation for the treatment of cheese whey. Bioresour. Technol. 98, 2102-2108. doi:10.1016/j.biortech.2006.08.013

Saddoud, A., Sayadi, S., 2007. Application of acidogenic fixed-bed reactor prior to anaerobic membrane bioreactor for sustainable slaughterhouse wastewater treatment. J. Hazard. Mater., Pollution Prevention and Restoration of the Environment 149, 700-706. doi:10.1016/j.jhazmat.2007.04.031 
Santos, A., Judd, S., 2010. The Commercial Status of Membrane Bioreactors for Municipal Wastewater. Sep. Sci. Technol. 45, 850-857.

doi:10.1080/01496391003662337

Scampini, A.C., 2010. Upflow anaerobic sludge blanket reactors for treatment of wastewater from the brewery industry (Thesis). Massachusetts Institute of Technology.

Sheehan, G.J., Greenfield, P.F., 1980. Utilisation, treatment and disposal of distillery wastewater. Water Res. 14, 257-277. doi:10.1016/0043-1354(80)90097-4

Siegrist, H., Hunziker W, H, H., 2005. Anaerobic digestion of slaughterhouse waste with UF-membrane separation and recycling of permeate after free ammonia stripping [WWW Document]. URL http://www.iwaponline.com/wst/05201/wst052010531.htm (accessed 11.11.14).

Simate, G.S., Cluett, J., Iyuke, S.E., Musapatika, E.T., Ndlovu, S., Walubita, L.F., Alvarez, A.E., 2011. The treatment of brewery wastewater for reuse: State of the art. Desalination 273, 235-247. doi:10.1016/j.desal.2011.02.035

Singh, K., Burke, D., Grant, S., 2011. Anarobic Flat Sheet Membrane Reactor Treating Food Processing Wastewater: Pilot-Scale Performance. Presented at the 12th World Congress on Anarobic Digestion, IWA Publishing, Mexico.

Skouteris, G., Hermosilla, D., López, P., Negro, C., Blanco, Á., 2012. Anaerobic membrane bioreactors for wastewater treatment: A review. Chem. Eng. J. 198199, 138-148. doi:10.1016/j.cej.2012.05.070

Stadlbauer, E., L, O., K, J., R, W., H, L., W, O., G, D., 1994. Anaerobic purification of brewery wastewater in biofilm reactors with and without a methanation cascade [WWW Document]. URL http://www.iwaponline.com/wst/03012/wst030120395.htm (accessed 10.30.14).

Stamatelatou, K., Kopsahelis, A., Blika, P. s., Paraskeva, C. a., Lyberatos, G., 2009. Anaerobic digestion of olive mill wastewater in a periodic anaerobic baffled reactor (PABR) followed by further effluent purification via membrane separation technologies. J. Chem. Technol. Biotechnol. 84, 909-917. doi:10.1002/jctb.2170

Stantec Ltd., 2012. Over Strength Surcharge Review for Toronto Water, City of Toronto.

Strohwald, N.K.H., Ross, W.R., 1992. Application of the ADUF ${ }^{\mathrm{R}}$ Process to Brewery Effluent on a Laboratory Scale [WWW Document]. URL http://www.iwaponline.com/wst/02510/wst025100095.htm (accessed 11.11.14).

Stuckey, D.C., 2012. Recent developments in anaerobic membrane reactors. Bioresour. Technol., Membrane Bioreactors (MBRs): State-of-Art and Future 122, 137-148. doi:10.1016/j.biortech.2012.05.138 
Torres, A., Hemmelmann, A., Vergara, C., Jeison, D., 2011. Application of two-phase slug-flow regime to control flux reduction on anaerobic membrane bioreactors treating wastewaters with high suspended solids concentration. Sep. Purif. Technol. 79, 20-25. doi:10.1016/j.seppur.2011.03.006

Van Zyl, P.J., Wentzel, M.C., Ekama, G.A., Riedel, K.J., 2008. Design and start-up of a high rate anaerobic membrane bioreactor for the treatment of a low $\mathrm{pH}$, high strength, dissolved organic waste water. Water Sci. Technol. 57, 291. doi:10.2166/wst.2008.083

Wang, X., Feng, Y.J., Lee, H., 2008. Electricity production from beer brewery wastewater using single chamber microbial fuel cell. Water Sci. Technol. 57, 1117. doi:10.2166/wst.2008.064

Wong, K., Xagoraraki, I., Wallace, J., Bickert, W., Srinivasan, S., Rose, J.B., 2009. Removal of viruses and indicators by anaerobic membrane bioreactor treating animal waste. J. Environ. Qual. 38, 1694-1699. doi:10.2134/jeq2008.0232

Yamamoto, K., Hiasa, M., Mahmood, T., Matsuo, T., 1989. Direct Solid-Liquid Separation Using Hollow Fiber Membrane in an Activated Sludge Aeration Tank [WWW Document]. URL

http://www.iwaponline.com/wst/02104/wst021040043.htm (accessed 11.10.14).

Yushina, Y., Hasegawa, J., 1994. Process performance comparison of membrane introduced anaerobic digestion using food industry waste water. Desalination 98, 413-421. doi:10.1016/0011-9164(94)00167-7

Zhang, S., Qu, Y., Liu, Y., Yang, F., Zhang, X., Furukawa, K., Yamada, Y., 2005. Experimental study of domestic sewage treatment with a metal membrane bioreactor. Desalination 177, 83-93. doi:10.1016/j.desal.2004.10.034

Zheng, T., Li, P., Wang, Q., Li, X., Ai, H., Gan, K., Sharavsambuu, A., 2014. Pilot-scale experiments on brewery wastewater treatment and sludge reduction based on food chain predation. Desalination Water Treat. 0, 1-10. doi:10.1080/19443994.2014.923334 


\section{CHAPTER 7 - $\quad$ APPENDICES}

Appendices include 1) AnMBR operation data summery 2) Critical flux determination 


\subsection{APPENDIX I - ANMBR OPERATION DATA}

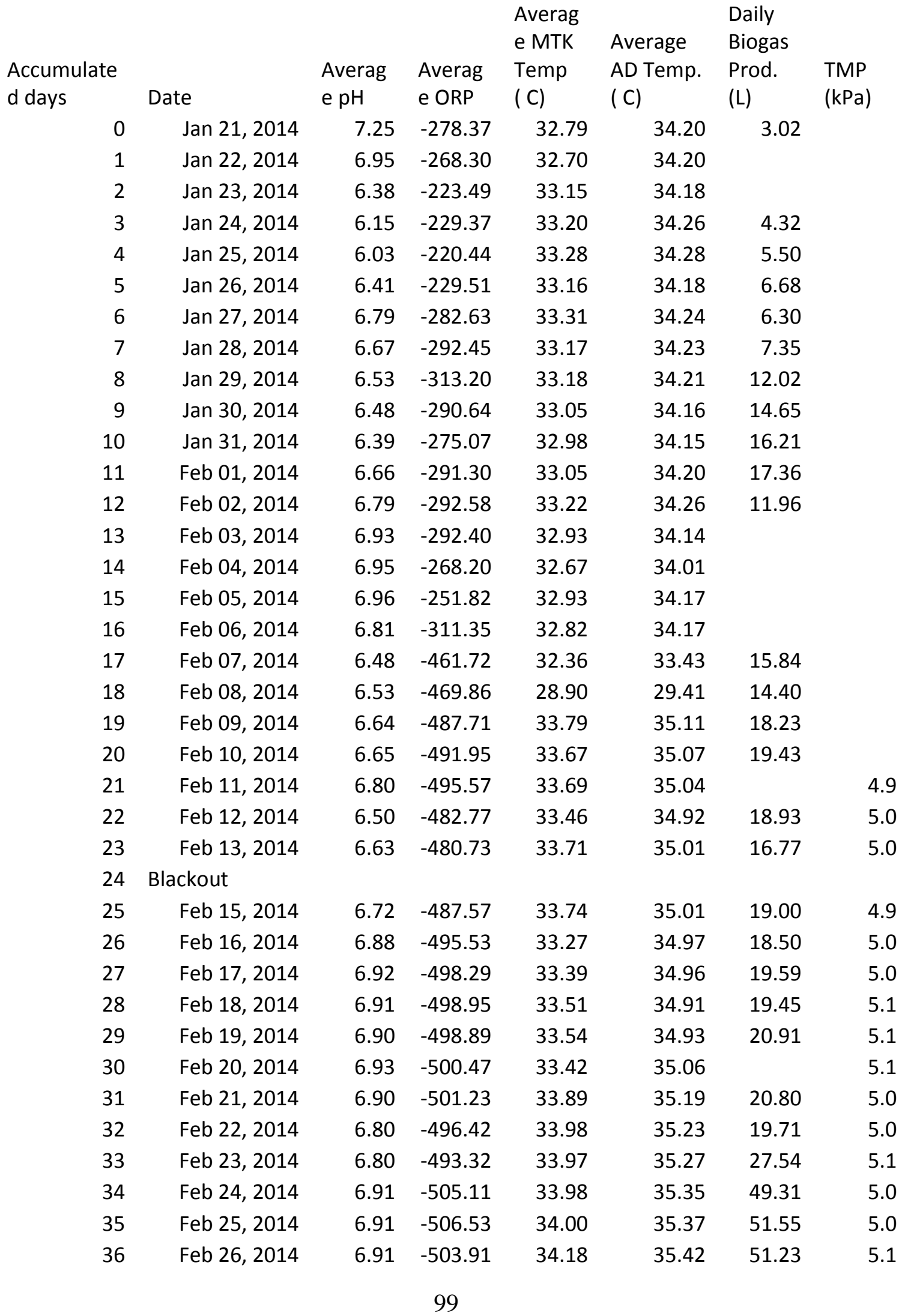




\begin{tabular}{|c|c|c|c|c|c|c|c|}
\hline 37 & Feb 27, 2014 & 6.91 & -501.44 & 34.40 & 35.52 & 51.51 & 5.1 \\
\hline 38 & Feb 28, 2014 & 6.91 & -500.07 & 34.09 & 35.39 & 52.34 & 5.2 \\
\hline 39 & Mar 01, 2014 & 6.91 & -499.05 & 33.98 & 35.36 & 52.72 & 5.2 \\
\hline 40 & Mar 02, 2014 & 6.89 & -498.13 & 33.94 & 35.34 & 54.30 & 5.3 \\
\hline 41 & Mar 03, 2014 & 6.83 & -494.95 & 33.94 & 35.34 & 54.49 & 5.2 \\
\hline 42 & Mar 04, 2014 & 6.83 & -494.90 & 33.57 & 35.41 & 56.44 & 5.3 \\
\hline 43 & Mar 05, 2014 & 6.83 & -493.82 & 33.10 & 35.53 & 54.11 & 5.3 \\
\hline 44 & Mar 06, 2014 & 6.82 & -491.57 & 33.67 & 35.51 & 55.95 & 5.2 \\
\hline 45 & Mar 07, 2014 & 6.82 & -490.87 & 34.17 & 35.46 & 54.56 & 5.2 \\
\hline 46 & Mar 08, 2014 & 6.83 & -490.34 & 34.17 & 35.44 & 50.59 & 5.3 \\
\hline 47 & Mar 09, 2014 & 6.82 & -489.34 & 34.16 & 35.42 & 50.83 & 5.2 \\
\hline 48 & Mar 10, 2014 & 6.82 & -488.91 & 34.08 & 35.35 & 52.45 & 5.2 \\
\hline 49 & Mar 11, 2014 & 6.81 & -488.04 & 33.47 & 35.12 & 52.52 & 5.2 \\
\hline 50 & Mar 12, 2014 & 6.81 & -487.39 & 34.11 & 35.35 & 52.85 & 5.2 \\
\hline 51 & Mar 13, 2014 & 6.81 & -487.15 & 34.31 & 35.40 & 53.30 & 5.4 \\
\hline 52 & Mar 14, 2014 & 6.82 & -486.88 & 34.31 & 35.38 & 49.59 & 5.3 \\
\hline 53 & Mar 15, 2014 & 6.82 & -486.86 & 34.25 & 35.41 & 52.28 & 5.2 \\
\hline 54 & Mar 16, 2014 & 6.81 & -486.42 & 33.93 & 35.28 & 52.38 & 5.4 \\
\hline 55 & Mar 17, 2014 & 6.81 & -485.23 & 33.54 & 35.10 & 51.86 & 5.3 \\
\hline 56 & Mar 18, 2014 & 6.81 & -480.71 & 34.08 & 35.37 & 55.27 & 5.3 \\
\hline 57 & Mar 19, 2014 & 6.82 & -468.53 & 33.49 & 35.19 & 63.53 & 5.4 \\
\hline 58 & Mar 20, 2014 & 6.82 & -469.62 & 33.55 & 35.22 & 79.08 & 5.4 \\
\hline 59 & Mar 21, 2014 & 6.91 & -473.07 & 33.59 & 35.19 & & 5.4 \\
\hline 60 & Mar 22, 2014 & 6.85 & -476.50 & 33.59 & 34.97 & 81.64 & 5.4 \\
\hline 61 & Mar 23, 2014 & 6.85 & -475.53 & 33.66 & 35.00 & 82.16 & 5.4 \\
\hline 62 & Mar 24, 2014 & 6.82 & -475.78 & 33.23 & 34.85 & 76.31 & 5.4 \\
\hline 63 & Mar 25, 2014 & 6.84 & -475.63 & 33.39 & 34.98 & 81.98 & 5.4 \\
\hline 64 & Mar 26, 2014 & 6.83 & -475.54 & 33.18 & 34.79 & 78.27 & 5.4 \\
\hline 65 & Mar 27, 2014 & 6.83 & -475.12 & 33.81 & 35.21 & 80.09 & 5.4 \\
\hline 66 & Mar 28, 2014 & 6.82 & -475.94 & 33.71 & 35.15 & 79.22 & 5.4 \\
\hline 67 & Mar 29, 2014 & 6.83 & -474.60 & 33.63 & 35.18 & 77.55 & 5.3 \\
\hline 68 & Mar 30, 2014 & 6.84 & -475.16 & 33.40 & 35.05 & 78.21 & 5.5 \\
\hline 69 & Mar 31, 2014 & 6.85 & -475.91 & 32.60 & 34.15 & & 5.7 \\
\hline 70 & Apr 01, 2014 & 6.83 & -476.15 & 33.62 & 35.41 & 80.26 & 5.6 \\
\hline 71 & Apr 02, 2014 & 6.88 & -475.38 & 33.66 & 35.44 & 74.89 & 5.7 \\
\hline 72 & Apr 03, 2014 & 7.22 & -485.02 & 33.83 & 35.42 & 75.33 & 5.7 \\
\hline 73 & Apr 04, 2014 & 7.07 & -484.94 & 33.78 & 35.42 & 91.80 & 5.7 \\
\hline 74 & Apr 05, 2014 & 7.37 & -338.46 & 33.72 & 35.33 & 79.46 & 5.7 \\
\hline 75 & Apr 06, 2014 & 7.25 & -310.77 & 33.21 & 35.12 & 84.80 & 6.0 \\
\hline 76 & Apr 07, 2014 & 7.23 & -360.90 & 33.38 & 35.09 & 91.78 & 6.6 \\
\hline 77 & Apr 08, 2014 & 7.24 & -387.09 & 32.78 & 34.91 & 90.90 & 6.2 \\
\hline 78 & Apr 09, 2014 & 7.23 & -403.91 & 32.79 & 34.90 & 87.75 & 6.2 \\
\hline 79 & Apr 10, 2014 & 7.24 & -417.06 & 33.00 & 35.04 & 89.70 & 6.2 \\
\hline
\end{tabular}




\begin{tabular}{|c|c|c|c|c|c|c|c|}
\hline 80 & Apr 11, 2014 & 7.25 & -427.56 & 33.33 & 35.18 & 91.13 & 6.2 \\
\hline 81 & Apr 12, 2014 & 7.25 & -435.36 & 32.95 & 35.18 & 91.39 & 6.6 \\
\hline 82 & Apr 13, 2014 & 7.36 & -346.69 & 33.54 & 35.26 & 64.58 & 6.4 \\
\hline 83 & Apr 14, 2014 & 7.34 & -316.53 & 33.25 & 35.23 & 76.31 & 6.5 \\
\hline 84 & Apr 15, 2014 & 7.23 & -359.86 & 33.38 & 35.40 & 91.49 & 6.6 \\
\hline 85 & Apr 16, 2014 & 7.21 & -264.09 & 32.53 & 34.86 & 33.76 & 7.1 \\
\hline 86 & Apr 17, 2014 & 7.22 & -266.07 & 33.04 & 34.83 & 0.00 & \\
\hline 87 & Apr 18, 2014 & 7.22 & -315.49 & 33.11 & 34.85 & 0.00 & 6.6 \\
\hline 88 & Apr 19, 2014 & 7.23 & -346.08 & 33.03 & 34.85 & 0.06 & 6.5 \\
\hline 89 & Apr 20, 2014 & 7.23 & -368.11 & 33.11 & 34.91 & 0.00 & 6.7 \\
\hline 90 & Apr 21, 2014 & 7.23 & -385.80 & 33.33 & 35.03 & 0.00 & 6.7 \\
\hline 91 & Apr 22, 2014 & 7.24 & -400.77 & 33.44 & 34.98 & 0.00 & 6.8 \\
\hline 92 & Apr 23, 2014 & 7.25 & -408.47 & 33.11 & 34.84 & 89.90 & 6.7 \\
\hline 93 & Apr 24, 2014 & 7.24 & -415.71 & 33.30 & 34.97 & 88.03 & 6.7 \\
\hline 94 & Apr 25, 2014 & 7.24 & -420.15 & 32.78 & 34.73 & 87.61 & 6.8 \\
\hline 95 & Blackout & & & & & & 6.3 \\
\hline 96 & Apr 27, 2014 & 7.24 & -417.30 & 33.29 & 34.70 & 33.62 & 6.5 \\
\hline 97 & Apr 28, 2014 & 7.23 & -455.96 & 33.11 & 34.89 & 85.06 & 6.6 \\
\hline 98 & Apr 29, 2014 & 7.24 & -470.13 & 32.76 & 34.75 & 94.05 & 6.6 \\
\hline 99 & Apr 30, 2014 & 7.24 & -474.64 & 33.14 & 34.87 & 79.88 & 6.6 \\
\hline 100 & May 01, 2014 & 7.23 & -476.23 & 32.95 & 34.78 & 26.26 & 6.6 \\
\hline 101 & May 02, 2014 & 7.23 & -477.91 & 33.35 & 34.96 & 83.35 & 6.6 \\
\hline 102 & May 03, 2014 & 7.22 & -478.12 & 33.06 & 34.85 & 81.70 & 6.7 \\
\hline 103 & May 04, 2014 & 7.25 & -479.24 & 32.87 & 34.76 & 77.38 & 6.7 \\
\hline 104 & May 05, 2014 & 7.24 & -478.80 & 33.50 & 35.03 & 0.08 & 6.7 \\
\hline 105 & May 06, 2014 & 7.24 & -477.63 & 33.07 & 34.91 & 0.08 & 6.7 \\
\hline 106 & May 07, 2014 & 7.22 & -476.72 & 32.91 & 34.85 & 0.08 & 6.8 \\
\hline 107 & May 08, 2014 & 7.22 & -476.08 & 32.96 & 34.89 & 0.07 & 6.8 \\
\hline 108 & May 09, 2014 & 7.21 & -476.81 & 33.46 & 35.15 & 0.06 & 6.8 \\
\hline 109 & May 10, 2014 & 7.21 & -477.16 & 33.46 & 35.11 & 0.06 & 6.8 \\
\hline 110 & May 11, 2014 & 7.21 & -477.40 & 33.85 & 35.24 & 0.07 & 6.9 \\
\hline 111 & May 12, 2014 & 7.21 & -478.14 & 33.48 & 35.08 & 0.07 & 6.9 \\
\hline 112 & May 13, 2014 & 7.21 & -440.29 & 33.42 & 35.11 & 0.07 & 6.9 \\
\hline 113 & May 14, 2014 & 7.23 & -432.97 & 33.62 & 35.16 & 0.07 & 6.8 \\
\hline 114 & May 15, 2014 & 7.23 & -447.35 & 33.24 & 35.03 & 0.07 & 7.0 \\
\hline 115 & May 16, 2014 & 7.23 & -454.48 & 32.54 & 34.74 & 0.08 & 7.1 \\
\hline 116 & May 17, 2014 & 7.25 & -458.58 & 32.71 & 34.93 & 0.08 & 7.0 \\
\hline 117 & May 18, 2014 & 7.27 & -462.41 & 33.08 & 35.12 & 0.07 & 7.0 \\
\hline 118 & May 19, 2014 & 7.26 & -464.94 & 33.11 & 35.13 & 0.07 & 6.9 \\
\hline 119 & May 20, 2014 & 7.24 & -465.89 & 33.25 & 35.18 & 0.07 & 6.8 \\
\hline 120 & May 21, 2014 & 7.24 & -466.38 & 33.29 & 35.22 & 0.07 & 6.9 \\
\hline 121 & May 22, 2014 & 7.23 & -467.49 & 33.37 & 35.25 & 0.10 & 6.9 \\
\hline 122 & May 23, 2014 & 7.23 & -466.96 & 33.22 & 35.17 & 89.91 & 6.9 \\
\hline
\end{tabular}




\begin{tabular}{|c|c|c|c|c|c|c|}
\hline 123 & May 24, 2014 & 7.22 & -467.60 & 33.38 & 35.23 & 0.03 \\
\hline 124 & May 25, 2014 & 7.22 & -469.56 & 33.29 & 35.21 & 0.07 \\
\hline 125 & May 26, 2014 & 7.24 & -469.93 & 33.63 & 35.46 & 44.55 \\
\hline 126 & May 27, 2014 & 7.22 & -467.33 & 33.89 & 35.69 & 82.72 \\
\hline 127 & May 28, 2014 & 7.22 & -467.60 & 33.57 & 35.55 & 25.13 \\
\hline 128 & May 29, 2014 & 7.21 & -469.45 & 33.67 & 35.55 & 87.64 \\
\hline 129 & May 30, 2014 & 7.20 & -470.35 & 33.59 & 35.55 & 84.70 \\
\hline 130 & May 31, 2014 & 7.21 & -470.91 & 33.26 & 35.42 & 81.54 \\
\hline 131 & Jun 01, 2014 & 7.23 & -471.14 & 33.62 & 35.58 & 83.04 \\
\hline 132 & Jun 02, 2014 & 7.24 & -472.00 & 33.57 & 35.57 & 72.66 \\
\hline 133 & Jun 03, 2014 & 7.26 & -470.05 & 33.08 & 35.29 & 77.08 \\
\hline 134 & Jun 04, 2014 & 7.24 & -470.09 & 33.48 & 35.53 & 100.09 \\
\hline 135 & Jun 05, 2014 & 7.24 & -471.13 & 33.81 & 35.61 & 82.63 \\
\hline 136 & Jun 06, 2014 & 7.24 & -471.63 & 33.75 & 35.62 & 8.32 \\
\hline 137 & Jun 07, 2014 & 7.25 & -460.11 & 34.03 & 35.72 & 0.07 \\
\hline 138 & Jun 08, 2014 & 7.25 & -470.20 & 33.81 & 35.67 & 0.07 \\
\hline 139 & Jun 09, 2014 & 7.23 & -471.88 & 33.89 & 35.70 & 21.15 \\
\hline 140 & Jun 10, 2014 & 7.25 & -474.52 & 33.99 & 35.73 & 81.28 \\
\hline \multicolumn{7}{|c|}{ Switched to Real Wastewater } \\
\hline 0 & Jun 11, 2014 & 7.25 & -476.01 & 34.18 & 35.79 & \\
\hline 1 & Jun 12, 2014 & 7.07 & -471.13 & 33.97 & 35.77 & 43.28 \\
\hline 2 & Jun 13, 2014 & 7.00 & -466.19 & 33.77 & 35.71 & 43.62 \\
\hline 3 & Jun 14, 2014 & 7.01 & -464.96 & 33.36 & 35.55 & 43.59 \\
\hline 4 & Jun 15, 2014 & 7.01 & -464.51 & 33.44 & 35.57 & 44.53 \\
\hline 5 & Jun 16, 2014 & 7.01 & -463.38 & 33.24 & 35.49 & 44.67 \\
\hline 6 & Jun 17, 2014 & 7.02 & -464.04 & 33.06 & 35.35 & 44.33 \\
\hline 7 & Jun 18, 2014 & 7.02 & -464.24 & 33.32 & 35.42 & 42.36 \\
\hline 8 & Jun 19, 2014 & 7.03 & -462.29 & 33.32 & 35.50 & 43.67 \\
\hline 9 & Jun 20, 2014 & 7.02 & -462.40 & 33.36 & 35.56 & 73.73 \\
\hline 10 & Jun 21, 2014 & 7.04 & -466.53 & 33.37 & 35.57 & 83.39 \\
\hline 11 & Jun 22, 2014 & 7.05 & -465.69 & 33.81 & 35.69 & 71.02 \\
\hline 12 & Jun 23, 2014 & 7.03 & -466.62 & 33.83 & 35.68 & 75.87 \\
\hline 13 & Jun 24, 2014 & 7.02 & -464.90 & 32.96 & 35.30 & 62.21 \\
\hline 14 & Jun 25, 2014 & 7.02 & -463.58 & 32.86 & 35.23 & 41.37 \\
\hline 15 & Jun 26, 2014 & 7.02 & -462.83 & 33.36 & 35.49 & 42.97 \\
\hline 16 & Jun 27, 2014 & 7.02 & -463.80 & 33.49 & 35.55 & 42.11 \\
\hline 17 & Jun 28, 2014 & 7.02 & -463.31 & 32.93 & 35.31 & \\
\hline 18 & Jun 29, 2014 & 7.00 & -460.57 & 32.58 & 35.21 & \\
\hline 19 & Jun 30, 2014 & 7.00 & -458.17 & 32.52 & 35.21 & \\
\hline 20 & Jul 01, 2014 & 7.02 & -447.30 & 32.64 & 35.23 & \\
\hline 21 & Jul 02, 2014 & 6.96 & -450.15 & 33.12 & 35.37 & 44.78 \\
\hline 22 & Jul 03, 2014 & 7.02 & -462.25 & 33.69 & 35.64 & 50.42 \\
\hline 23 & Jul 04, 2014 & 7.02 & -463.78 & 33.73 & 35.64 & 41.88 \\
\hline
\end{tabular}




\begin{tabular}{|c|c|c|c|c|c|c|c|}
\hline 24 & Jul 05, 2014 & 7.05 & -463.95 & 33.74 & 35.68 & & 6.8 \\
\hline 25 & Jul 06, 2014 & 6.98 & -463.06 & 34.02 & 35.77 & 43.45 & 6.8 \\
\hline 26 & Jul 07, 2014 & 7.02 & -465.51 & 33.68 & 35.60 & 45.45 & 7.0 \\
\hline 27 & Jul 08, 2014 & 7.02 & -465.21 & 33.13 & 35.34 & & 6.8 \\
\hline 28 & Jul 09, 2014 & 7.02 & -465.55 & 33.36 & 35.52 & 46.37 & 6.9 \\
\hline 29 & Jul 10, 2014 & 7.03 & -466.26 & 33.79 & 35.73 & 42.86 & 7.2 \\
\hline 30 & Jul 11, 2014 & 7.01 & -467.62 & 34.36 & 35.96 & 26.22 & 7.0 \\
\hline 31 & Jul 12, 2014 & 7.01 & -469.31 & 34.25 & 36.00 & 26.37 & 6.8 \\
\hline 32 & Jul 13, 2014 & 7.01 & -466.70 & 33.95 & 35.96 & 24.02 & 7.0 \\
\hline 33 & Jul 14, 2014 & 7.01 & -467.53 & 33.81 & 35.90 & 22.93 & 7.0 \\
\hline 34 & Jul 15, 2014 & 7.01 & -466.89 & 33.76 & 35.86 & 21.86 & 6.8 \\
\hline 35 & Jul 16, 2014 & 7.01 & -467.05 & 33.61 & 35.79 & 24.75 & 6.9 \\
\hline 36 & Jul 17, 2014 & 7.01 & -467.21 & 33.64 & 35.81 & 26.17 & 7.8 \\
\hline 37 & Jul 18, 2014 & 7.01 & -468.20 & 33.71 & 35.84 & 26.41 & 7.9 \\
\hline 38 & Jul 19, 2014 & 7.00 & -465.70 & 33.75 & 35.88 & 29.70 & 7.9 \\
\hline 39 & Jul 20, 2014 & 7.01 & -469.16 & 33.83 & 35.92 & & 7.6 \\
\hline 40 & Jul 21, 2014 & 7.02 & -472.43 & 34.29 & 36.06 & & 7.7 \\
\hline 41 & Jul 22, 2014 & 7.01 & -471.41 & 34.21 & 35.73 & 29.82 & 7.8 \\
\hline 42 & Jul 23, 2014 & 7.01 & -473.39 & 33.65 & 35.05 & 31.25 & 7.6 \\
\hline 43 & Jul 24, 2014 & 7.01 & -474.07 & 33.05 & 34.94 & 30.49 & 7.4 \\
\hline 44 & Jul 25, 2014 & 7.02 & -471.82 & 32.51 & 34.90 & 25.00 & 7.5 \\
\hline 45 & Jul 26, 2014 & 7.02 & -472.18 & 32.63 & 34.93 & 24.47 & 7.5 \\
\hline 46 & Jul 27, 2014 & 7.02 & -471.46 & 32.58 & 34.92 & 24.71 & 7.5 \\
\hline 47 & Jul 28, 2014 & 7.01 & -472.07 & 32.86 & 35.05 & 24.90 & 7.5 \\
\hline 48 & Jul 29, 2014 & 7.01 & -472.16 & 33.08 & 35.13 & 25.14 & 7.5 \\
\hline 49 & Jul 30, 2014 & 7.01 & -469.82 & 33.04 & 35.13 & 31.38 & 7.2 \\
\hline 50 & Jul 31, 2014 & 7.01 & -474.48 & 33.07 & 35.13 & 38.67 & 7.4 \\
\hline 51 & Aug 01, 2014 & 7.01 & -473.69 & 32.92 & 35.09 & 39.27 & 7.9 \\
\hline 52 & Aug 02, 2014 & 7.01 & -473.69 & 32.84 & 35.07 & 39.04 & 7.9 \\
\hline 53 & Aug 03, 2014 & 7.01 & -473.41 & 32.64 & 34.99 & 37.34 & 8.2 \\
\hline 54 & Aug 04, 2014 & 7.01 & -473.38 & 32.70 & 35.04 & 34.78 & 8.3 \\
\hline 55 & Aug 05, 2014 & 7.01 & -472.58 & 32.66 & 35.05 & 34.90 & 8.2 \\
\hline 56 & Aug 06, 2014 & 7.01 & -473.26 & 32.62 & 35.03 & 37.71 & 8.0 \\
\hline 57 & Aug 07, 2014 & 7.01 & -473.32 & 32.74 & 35.10 & 37.59 & 8.4 \\
\hline 58 & Aug 08, 2014 & 7.01 & -471.46 & 32.86 & 35.13 & 34.74 & 8.5 \\
\hline 59 & Aug 09, 2014 & 6.96 & -468.92 & 32.79 & 35.04 & 39.40 & 8.5 \\
\hline 60 & Aug 10, 2014 & 6.91 & -465.64 & 32.79 & 35.12 & 44.18 & 8.7 \\
\hline 61 & Aug 11, 2014 & 7.02 & -473.06 & 32.79 & 35.12 & 43.83 & 8.7 \\
\hline 62 & Aug 12, 2014 & 7.02 & -471.57 & 32.78 & 35.11 & 44.81 & 8.7 \\
\hline 63 & Aug 13, 2014 & 7.02 & -472.40 & 32.77 & 35.11 & 37.15 & 8.7 \\
\hline 64 & Aug 14, 2014 & 7.02 & -472.75 & 32.57 & 35.05 & 38.16 & 9.1 \\
\hline 65 & Aug 15, 2014 & 7.02 & -472.92 & 32.68 & 35.07 & 40.94 & 9.3 \\
\hline 66 & Aug 16, 2014 & 7.02 & -473.27 & 32.86 & 35.11 & 38.06 & 9.5 \\
\hline
\end{tabular}




$\begin{array}{rrrrrrrr}67 & \text { Aug 17, 2014 } & 7.01 & -472.30 & 32.95 & 35.14 & & 8.6 \\ 68 & \text { Aug 18, 2014 } & 7.01 & -476.07 & 24.02 & 35.55 & & \\ 69 & \text { Aug 19, 2014 } & 7.02 & -477.93 & 20.61 & 35.62 & & \\ 70 & \text { Aug 20, 2014 } & 7.03 & -478.97 & 21.16 & 35.68 & & \\ 71 & \text { Aug 21, 2014 } & 7.08 & -476.62 & 21.73 & 35.77 & & \\ 72 & \text { Aug 22, 2014 } & 7.09 & -476.51 & 20.98 & 35.78 & & \\ 73 & \text { Aug 23, 2014 } & 7.12 & -477.82 & 21.16 & 35.79 & & \\ 74 & \text { Aug 24, 2014 } & 7.16 & -478.88 & 21.22 & 35.77 & & \\ 75 & \text { Aug 25, 2014 } & 7.14 & -472.68 & 27.15 & 35.65 & & 8.6 \\ 76 & \text { Aug 26, 2014 } & 7.00 & -474.61 & 35.71 & 35.51 & 43.19 & 8.6 \\ 77 & \text { Aug 27, 2014 } & 7.01 & -475.50 & 35.45 & 35.41 & 39.89 & 8.0 \\ 78 & \text { Aug 28, 2014 } & 7.01 & -474.89 & 35.44 & 35.38 & 38.05 & 8.3 \\ 79 & \text { Aug 29, 2014 } & 7.01 & -475.44 & 35.71 & 35.45 & 37.65 & 8.6 \\ 80 & \text { Aug 30, 2014 } & 7.01 & -474.41 & 35.92 & 35.53 & 37.53 & 8.7 \\ 81 & \text { Aug 31, 2014 } & 7.04 & -475.50 & 36.21 & 35.63 & 39.14 & 8.6 \\ 82 & \text { Sep 01, 2014 } & 7.01 & -474.13 & 36.67 & 35.75 & 42.23 & 8.7 \\ 83 & \text { Sep 02, 2014 } & 7.02 & -472.14 & 36.80 & 35.78 & 46.80 & 8.3 \\ 84 & \text { Sep 03, 2014 } & 7.02 & -473.98 & 36.81 & 35.61 & 48.92 & 9.0 \\ 85 & \text { Sep 04, 2014 } & 7.02 & -472.76 & 36.76 & 35.42 & 48.71 & 9.2 \\ 86 & \text { Sep 05, 2014 } & 7.02 & -471.51 & 37.28 & 35.58 & 50.13 & 9.3 \\ 87 & \text { Sep 06, 2014 } & 7.02 & -472.44 & 37.24 & 35.52 & 47.27 & 9.7 \\ 88 & \text { Sep 07, 2014 } & 7.01 & -472.15 & 37.32 & 35.53 & 40.02 & 10.2 \\ 89 & \text { Sep 08, 2014 } & 7.03 & -473.38 & 37.58 & 35.63 & 40.17 & 10.4 \\ 90 & \text { Sep 09, 2014 } & 7.01 & -473.03 & 37.79 & 35.57 & & 10.6\end{array}$


7.2. APPENDIX II - CRITICAL FLUX DATA 


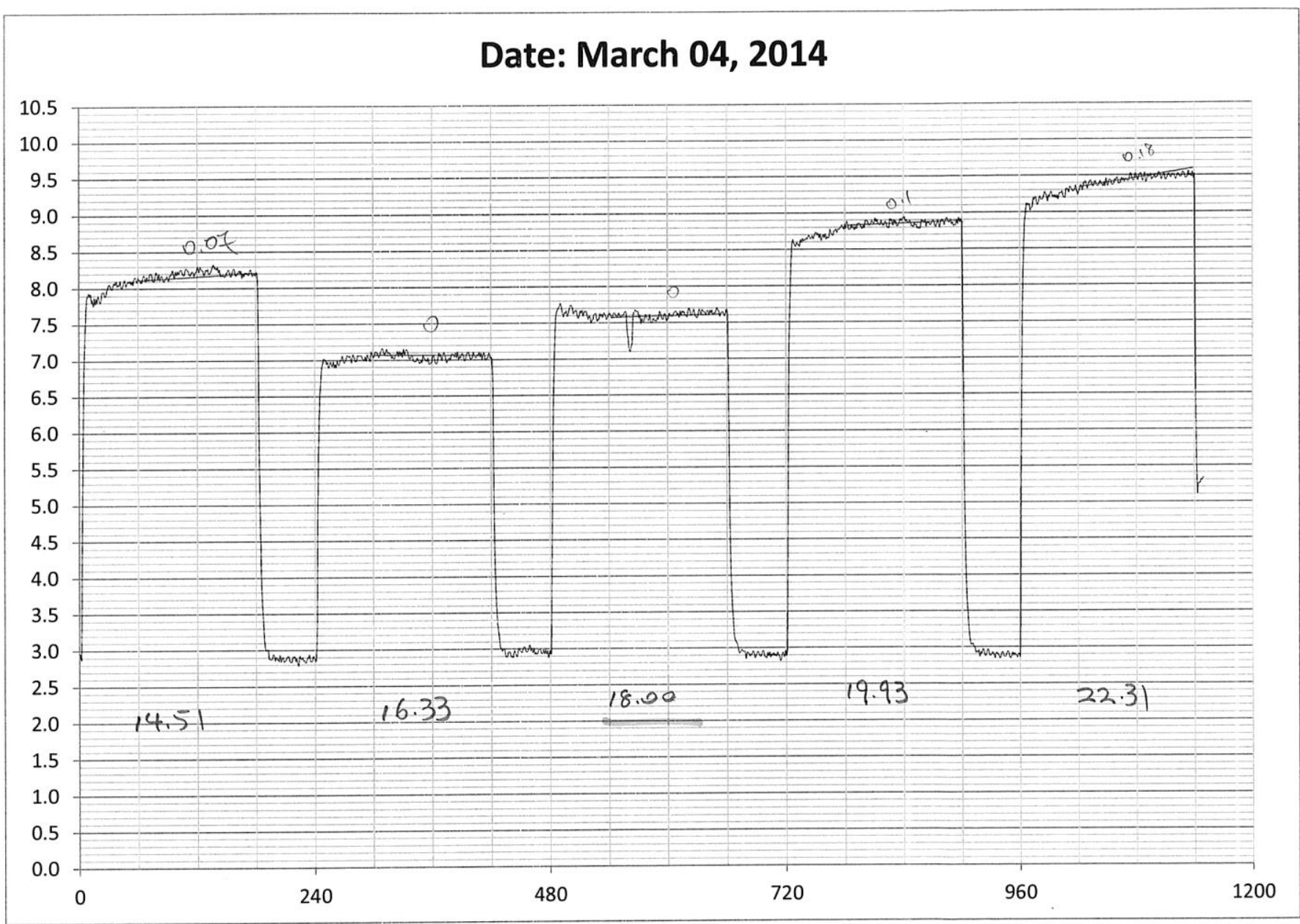




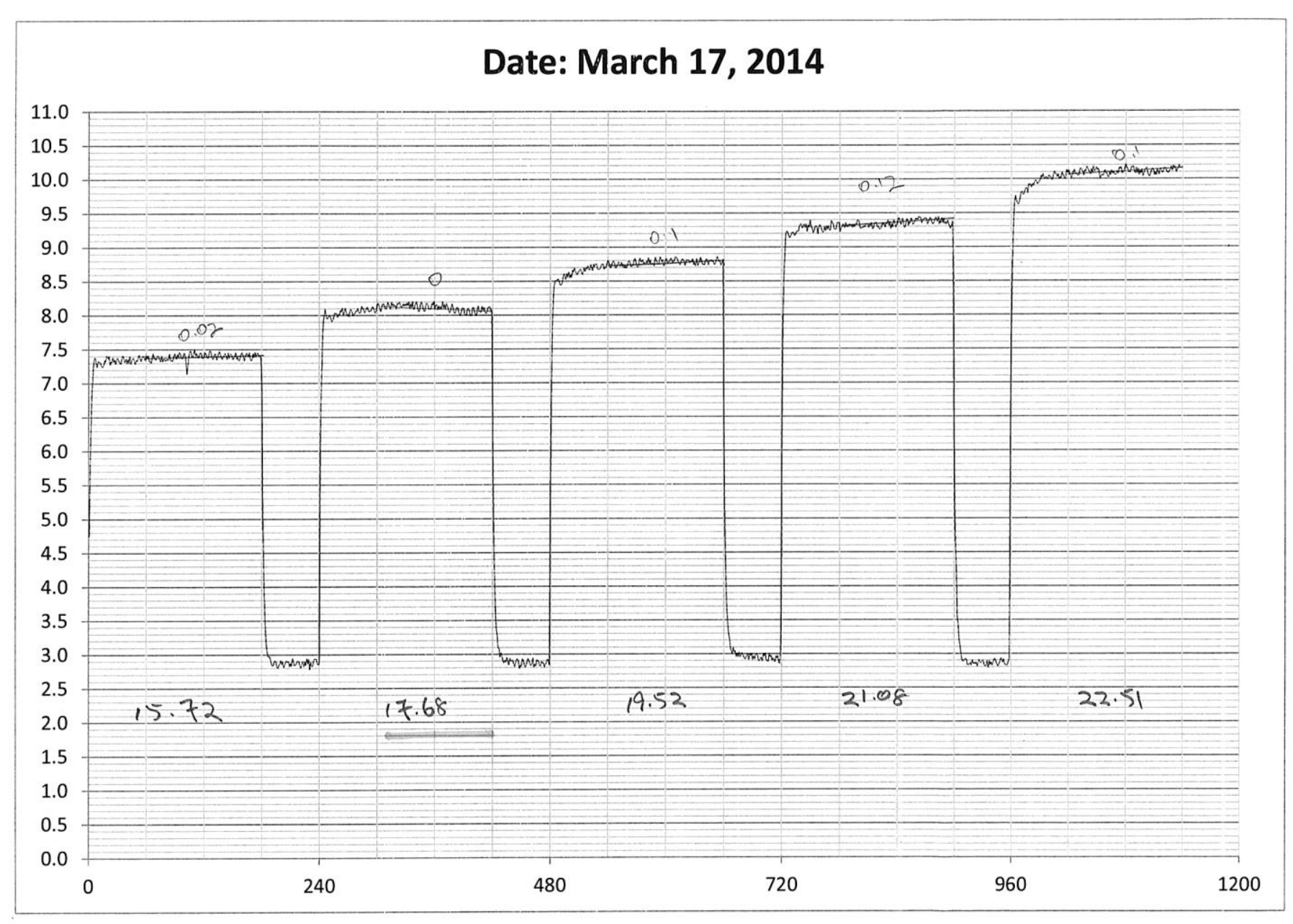




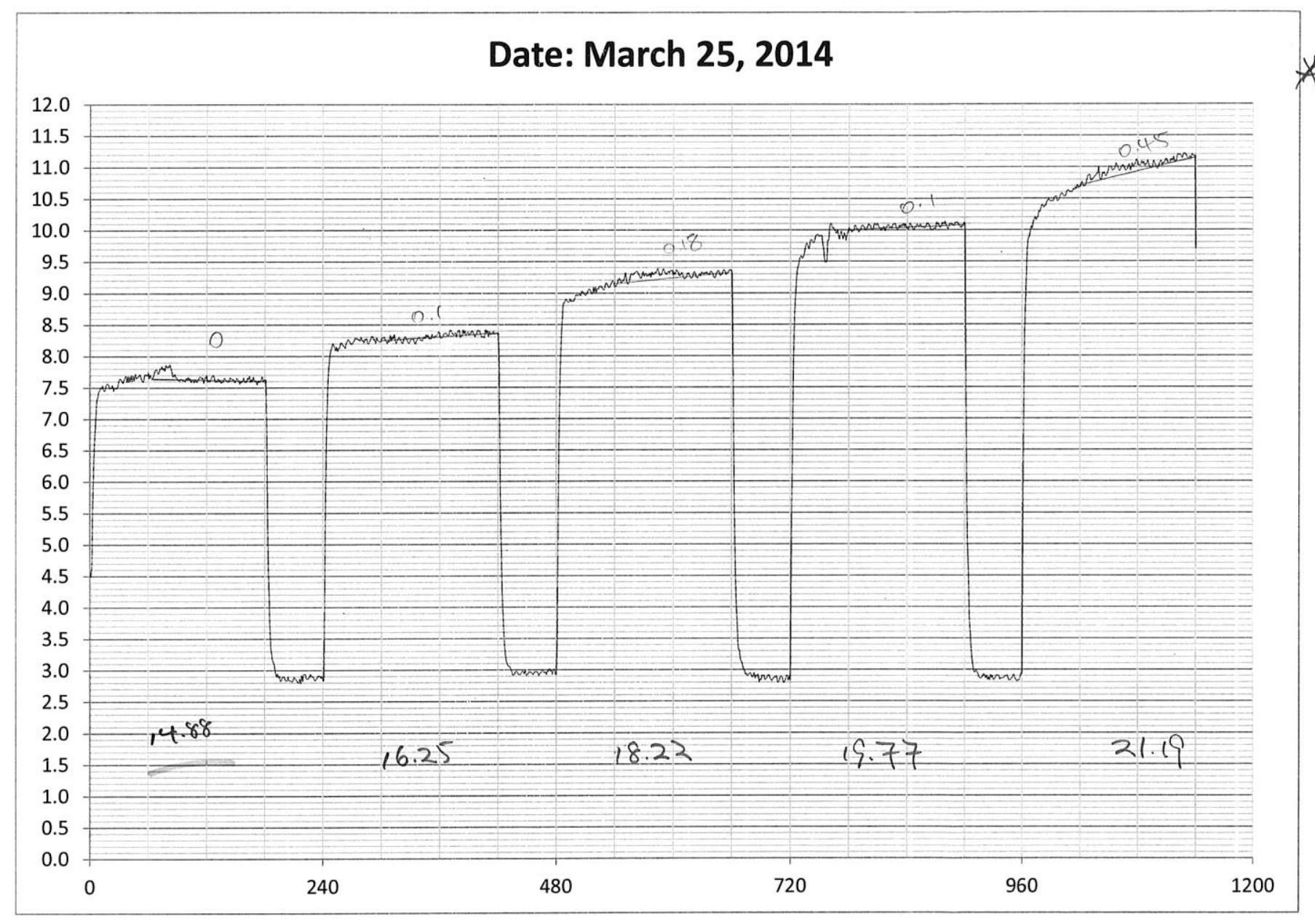




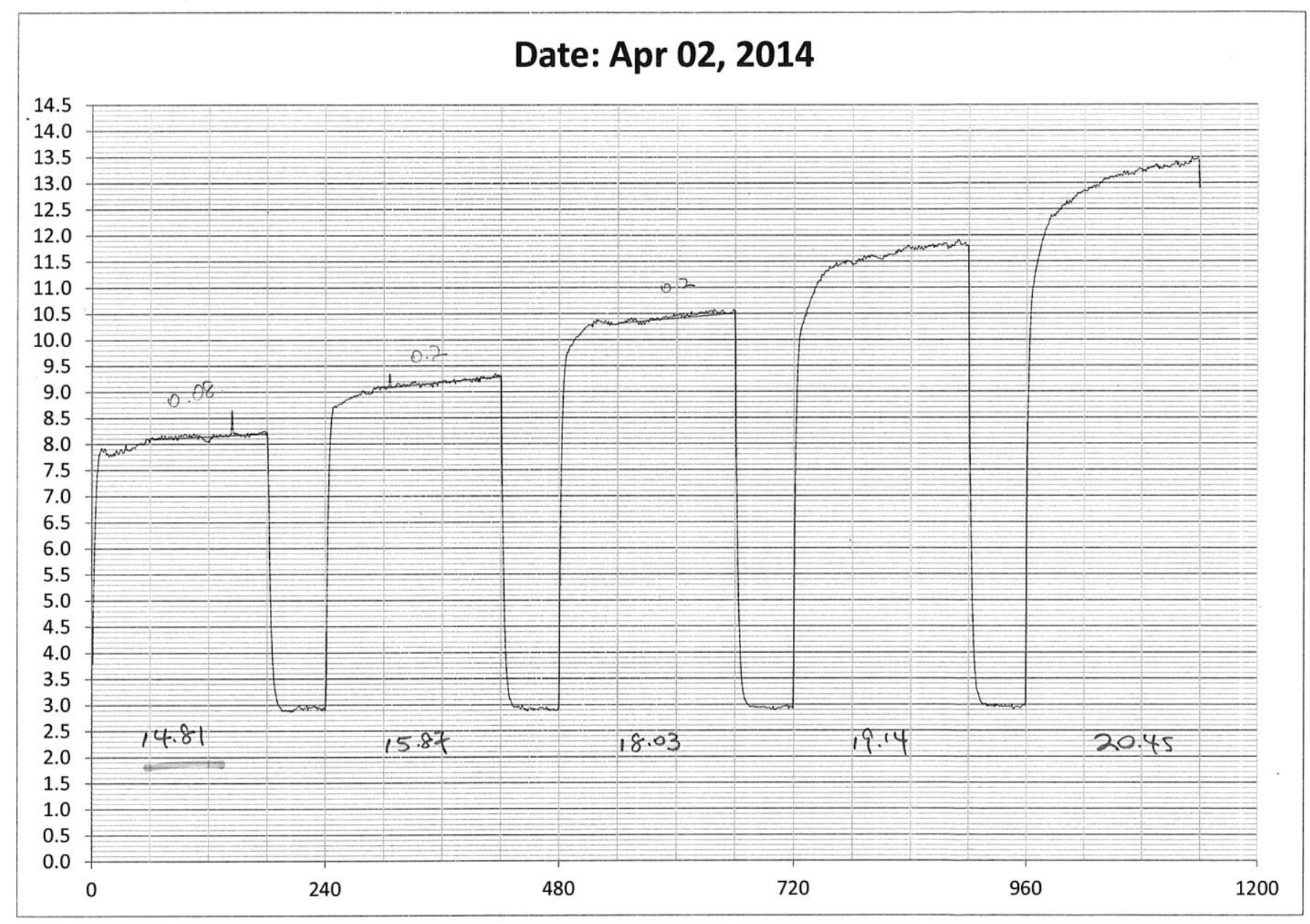


80

$10-9$

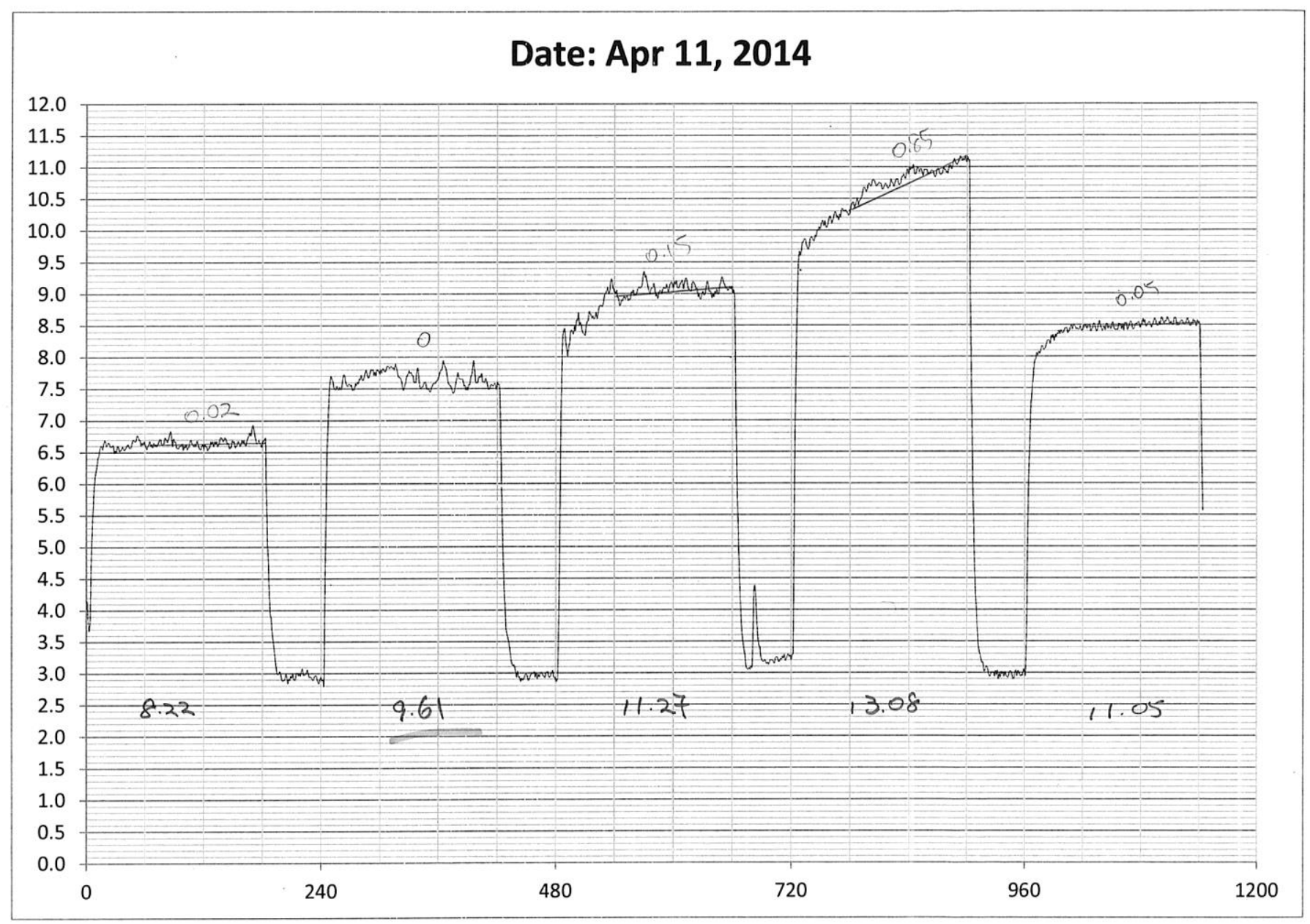

110 
91

$10-20$

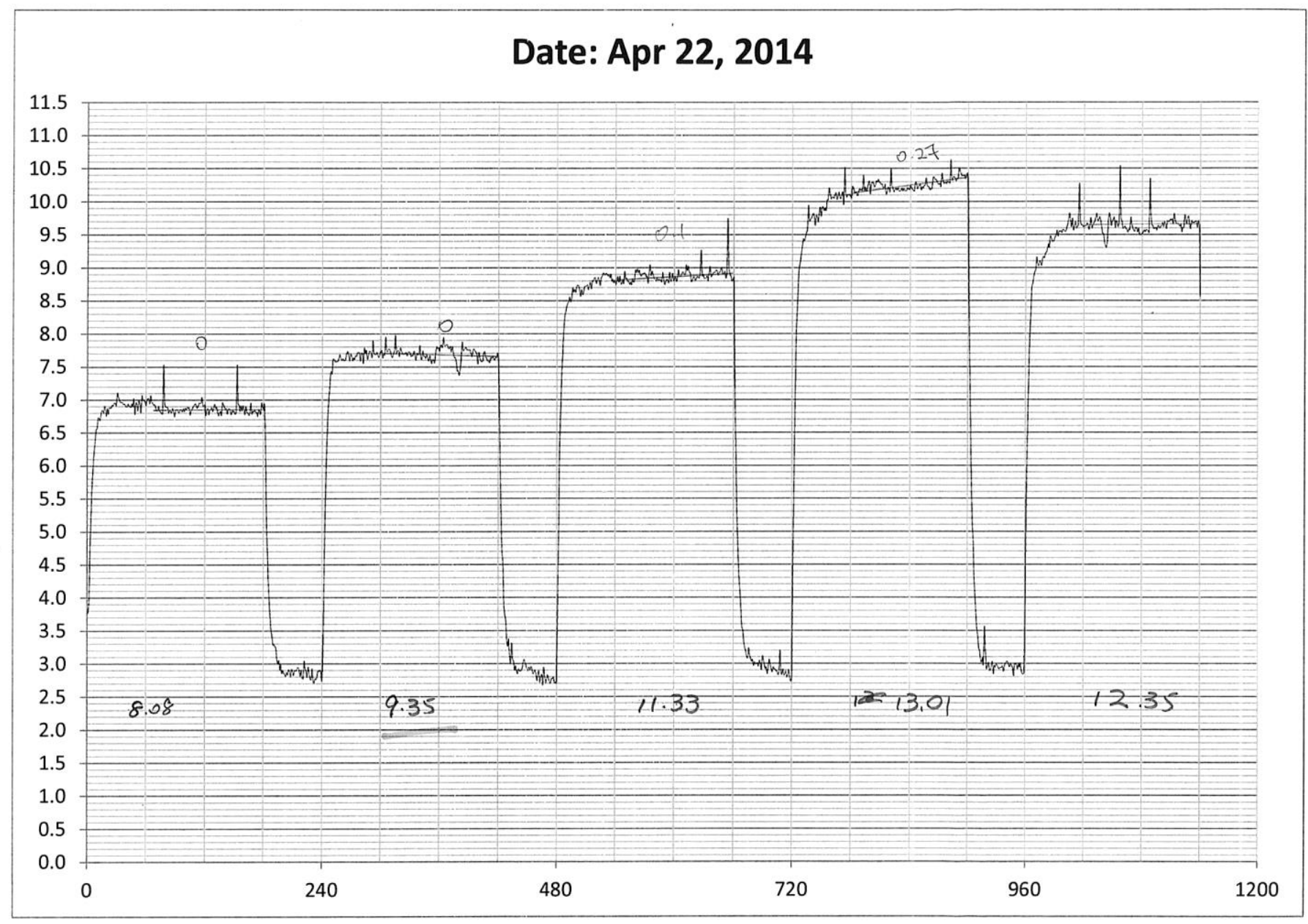

111 


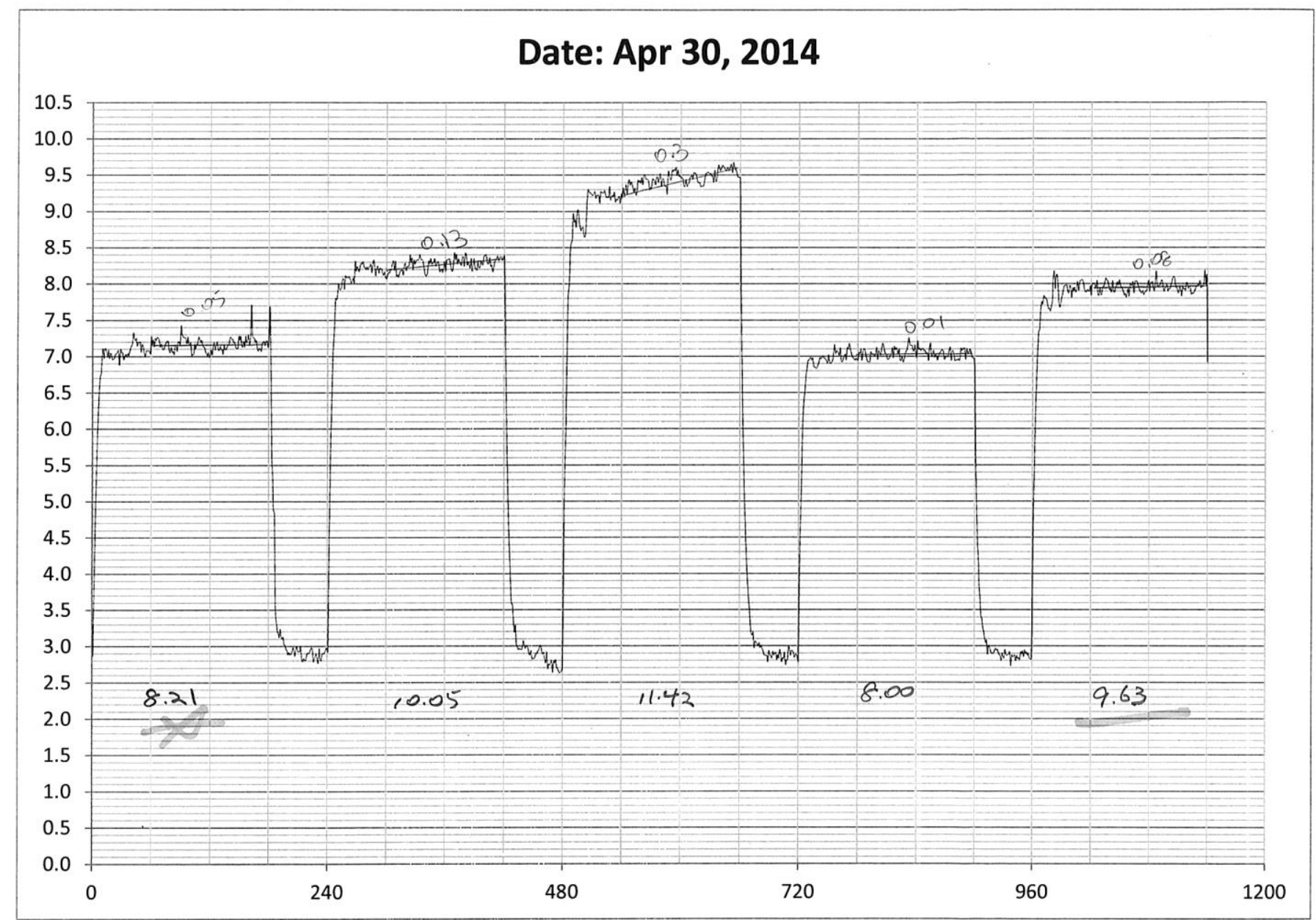




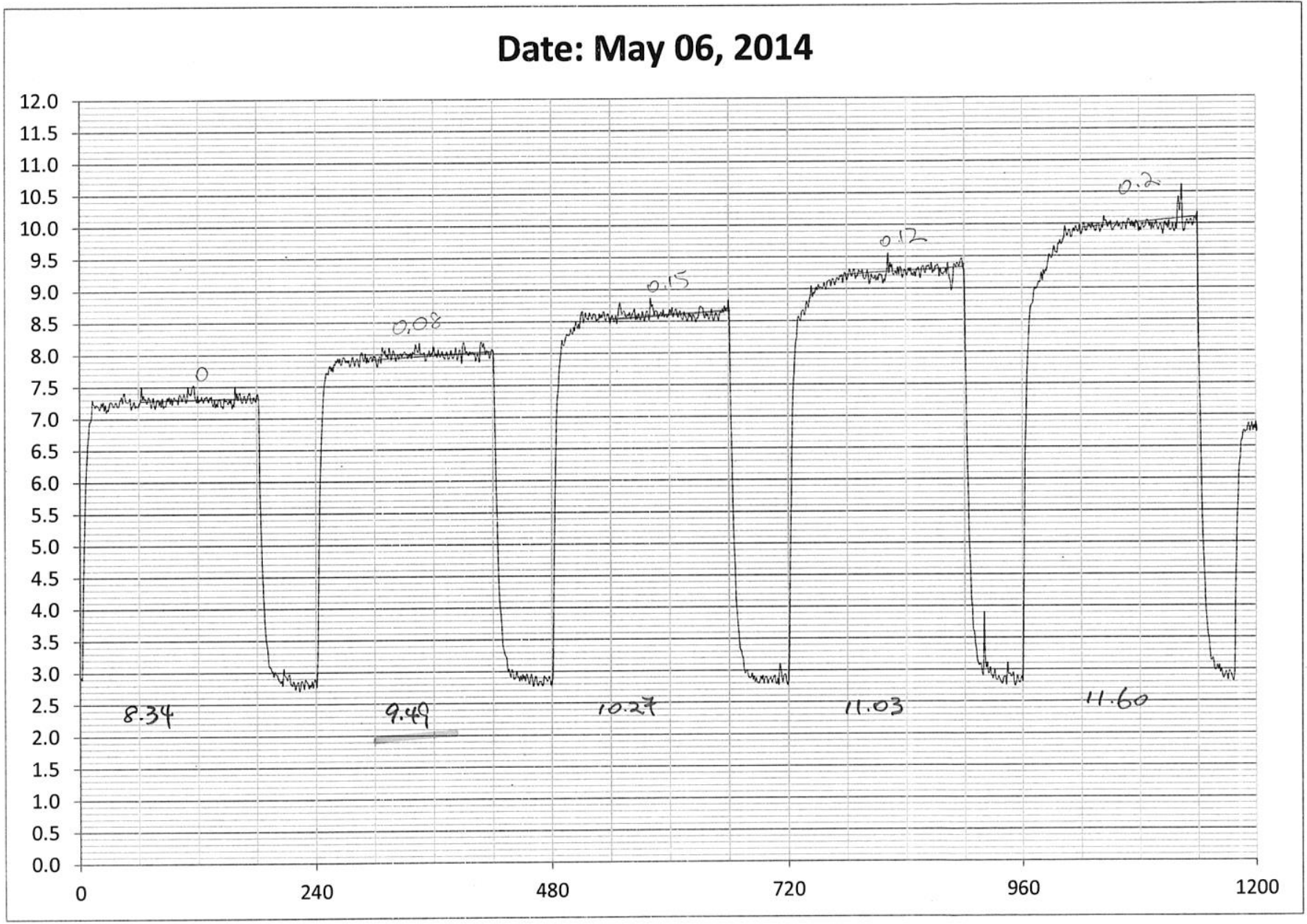




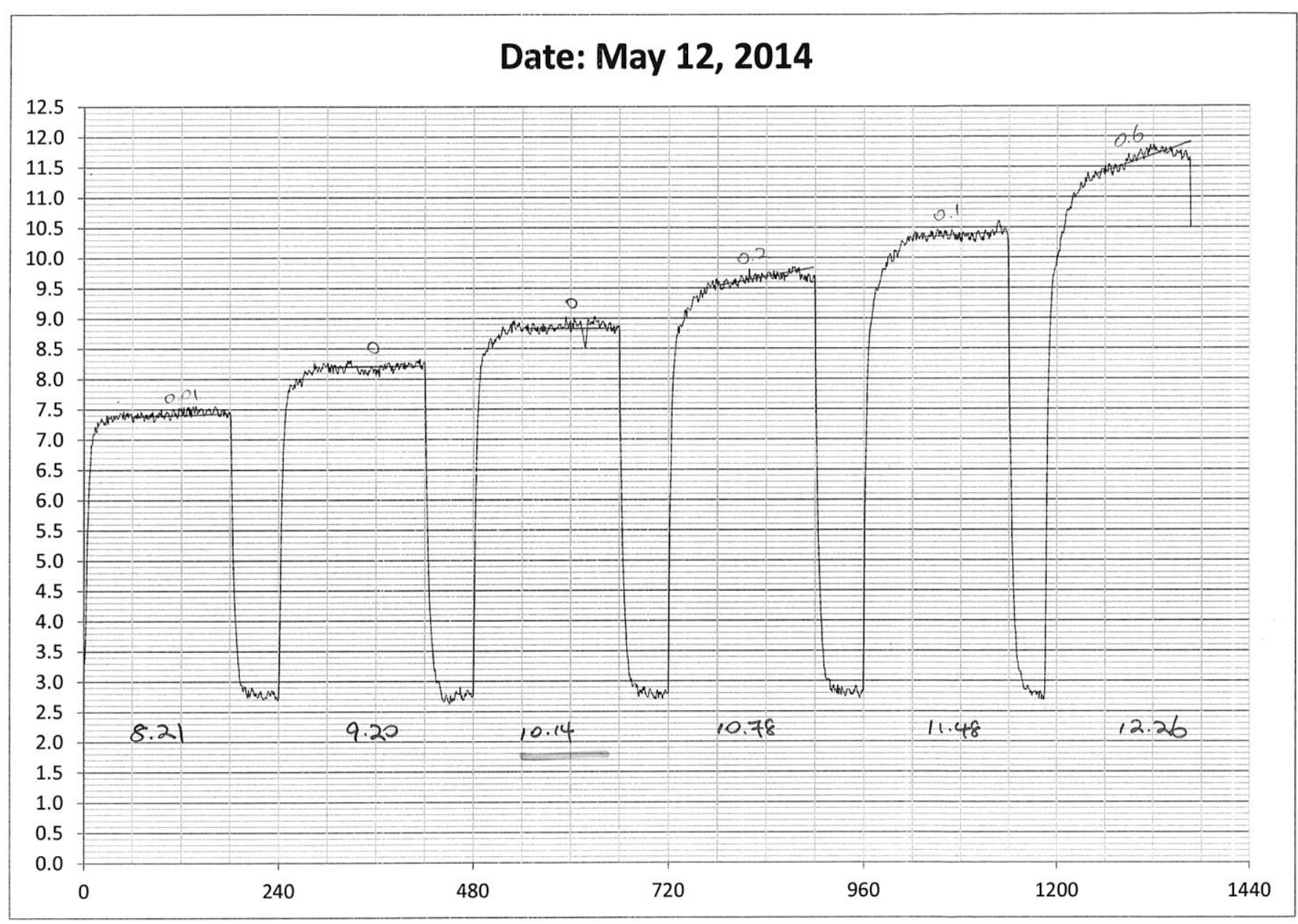




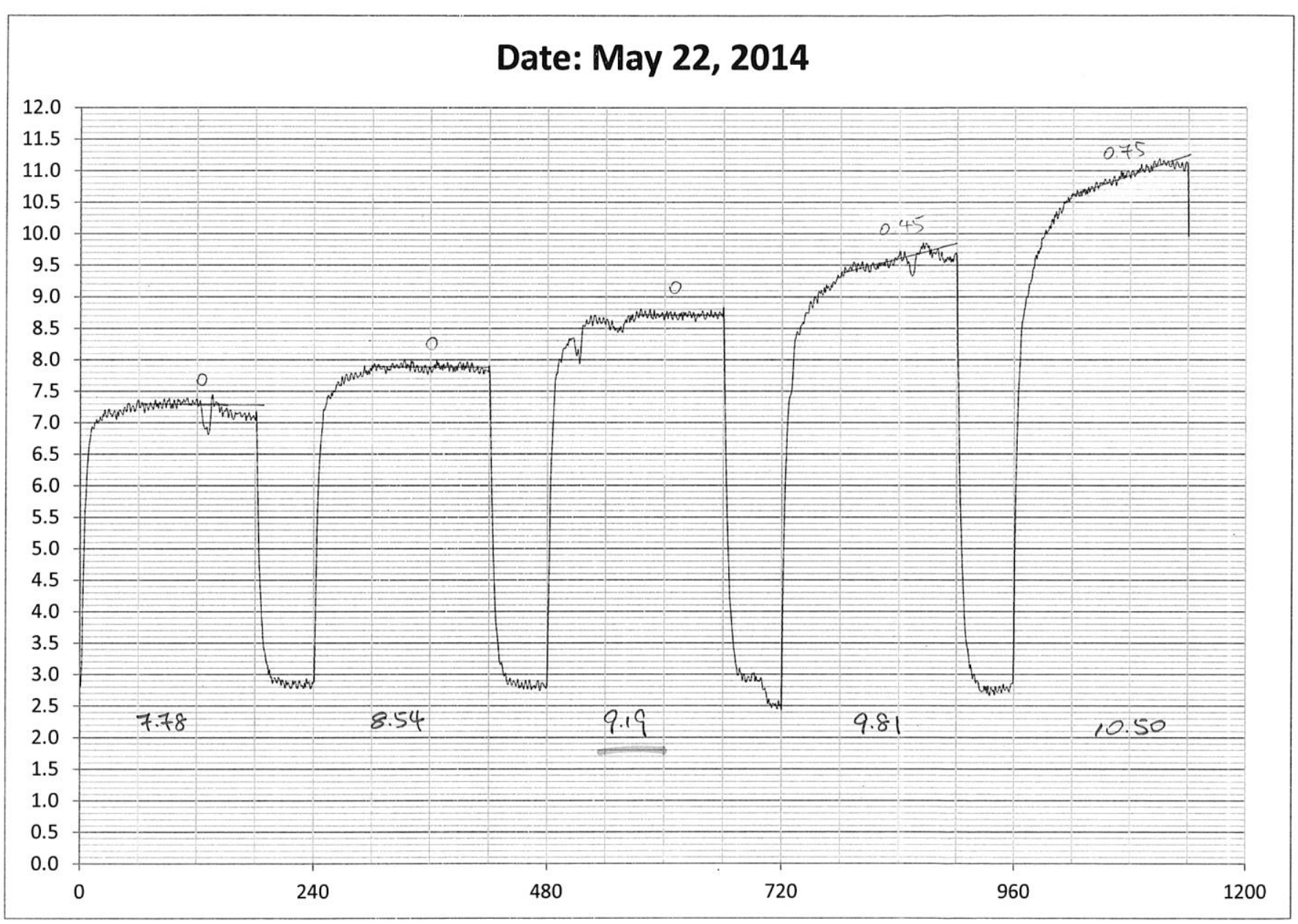




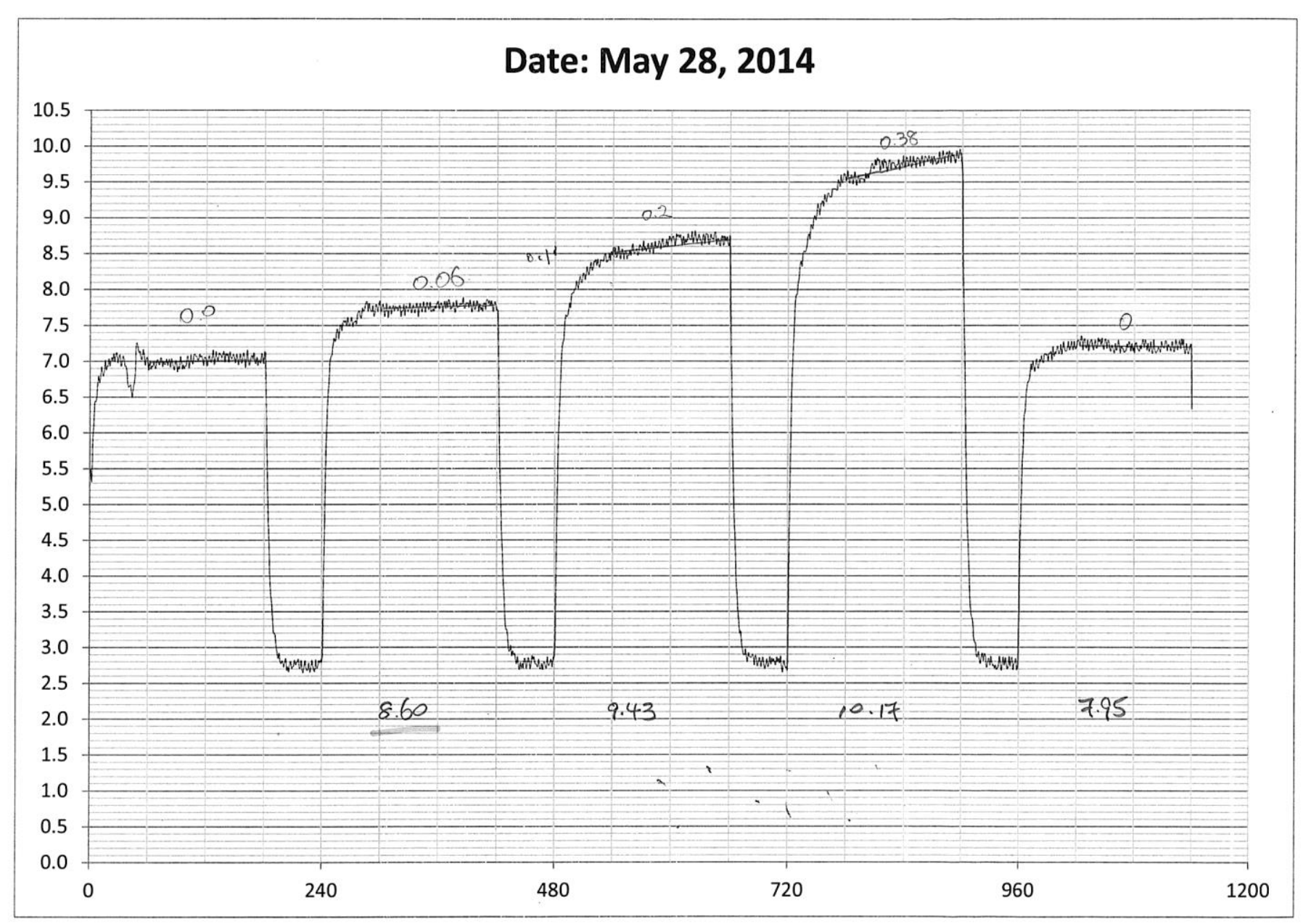




\section{Date: May June 02, 2014, 50\%}

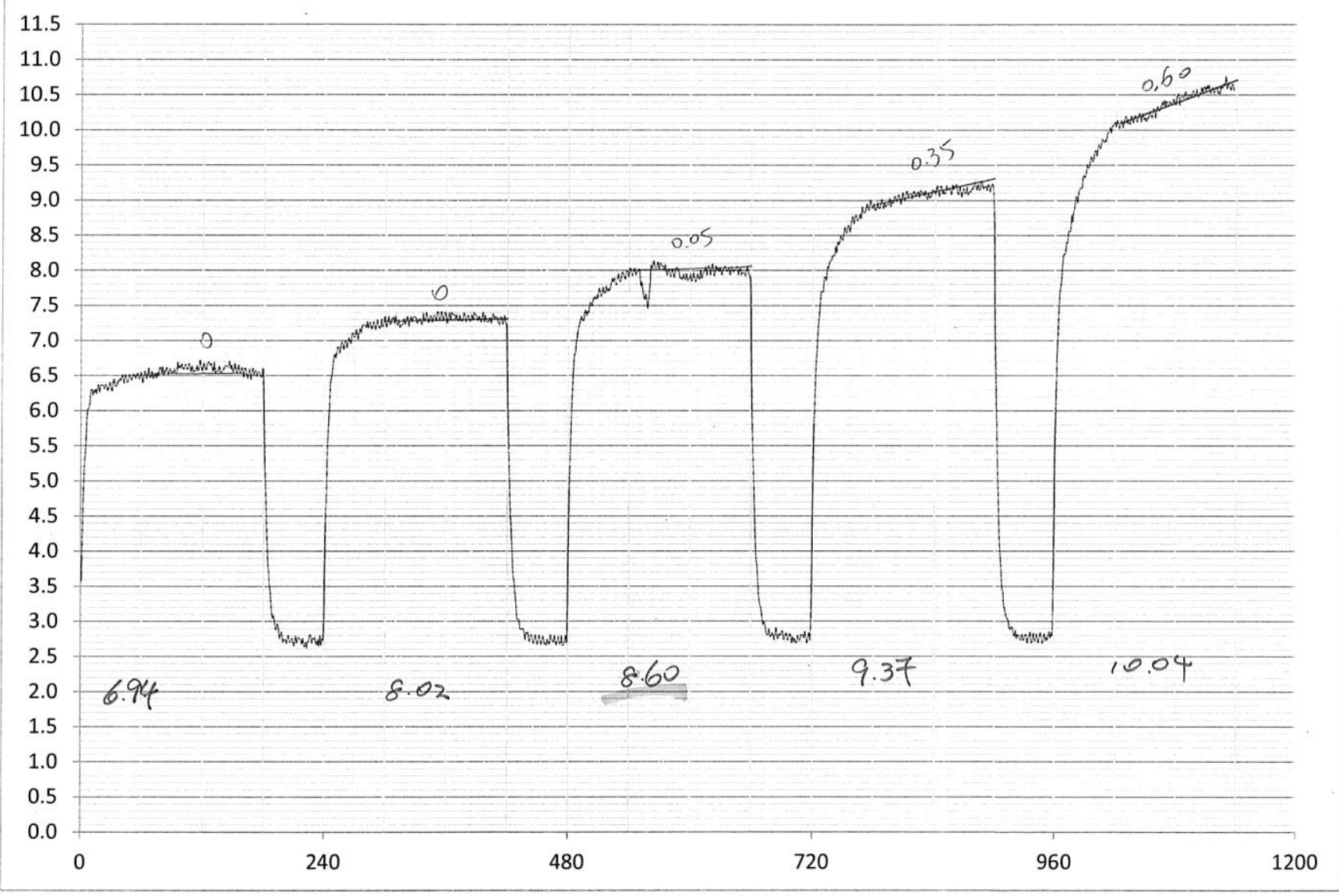


Synthetic w.w.

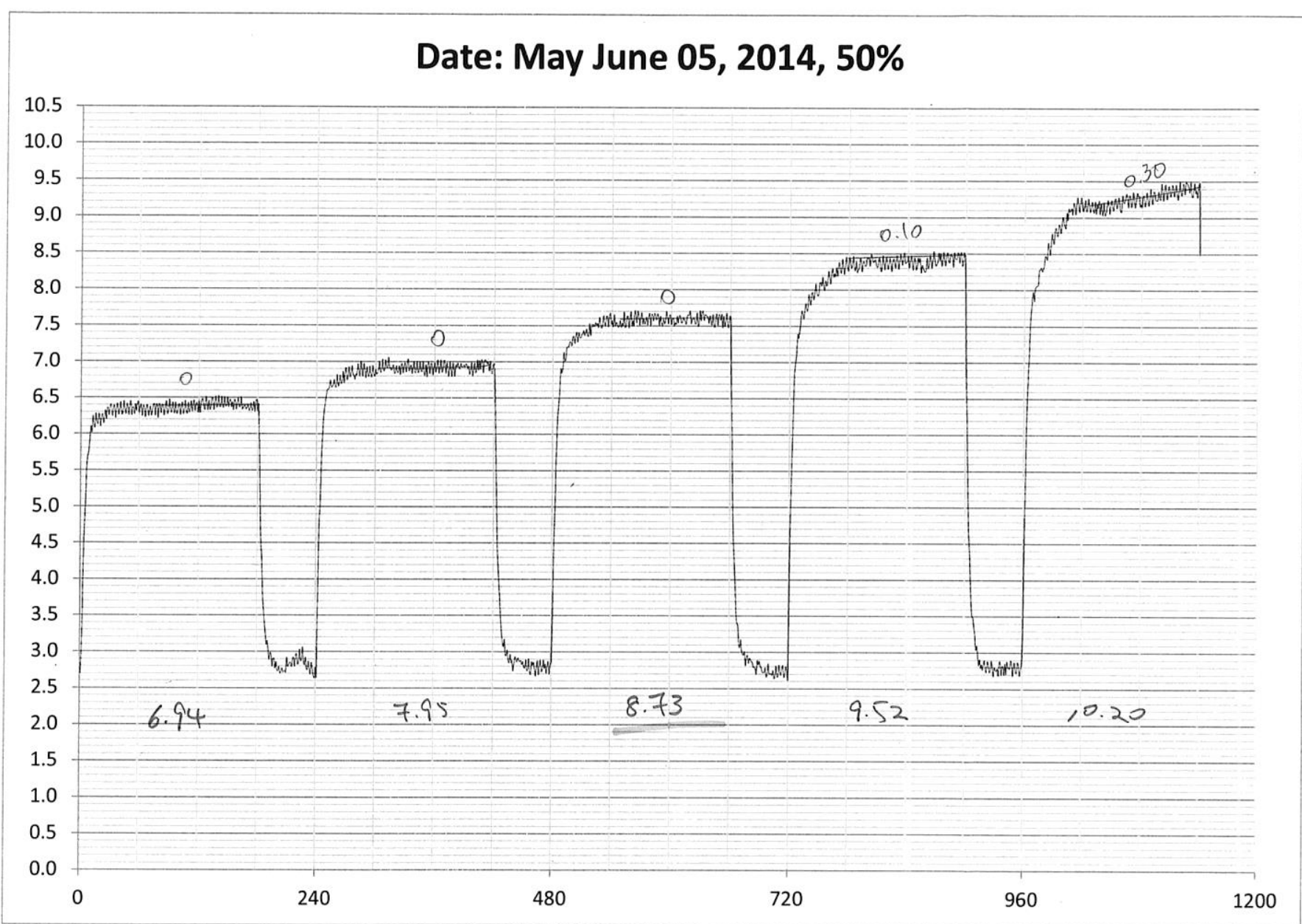


Air scouring rate. (synthetic)

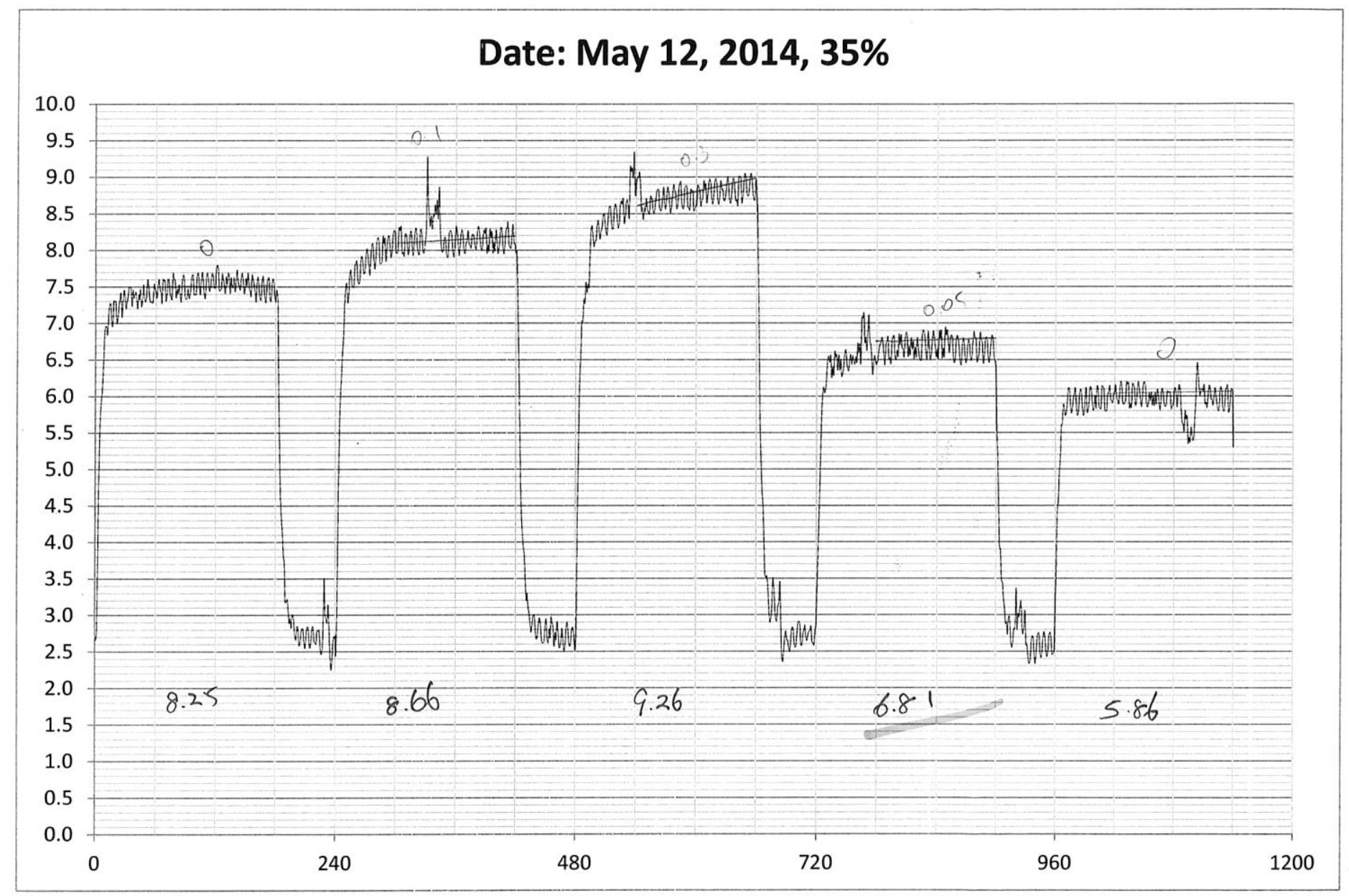

119 


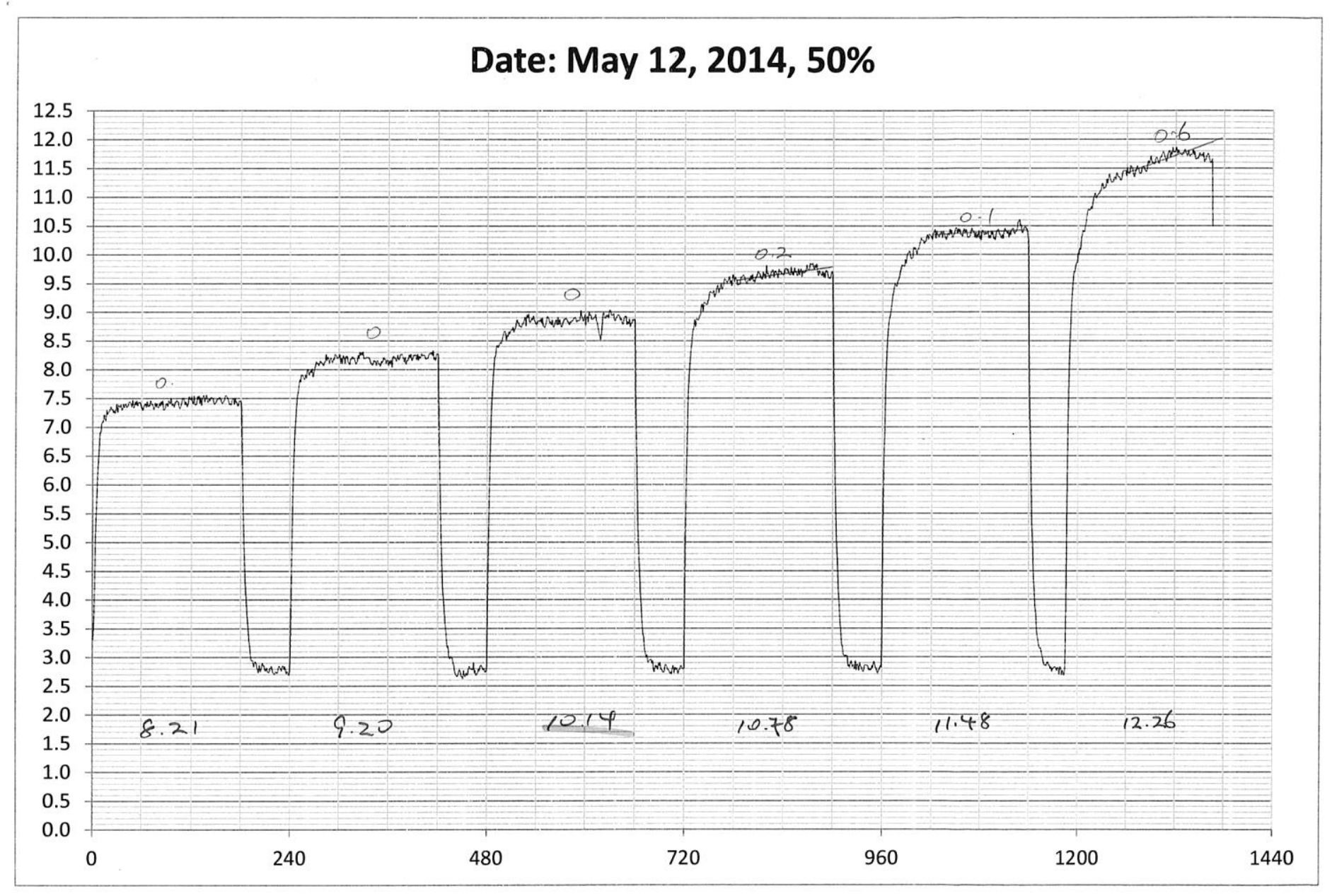




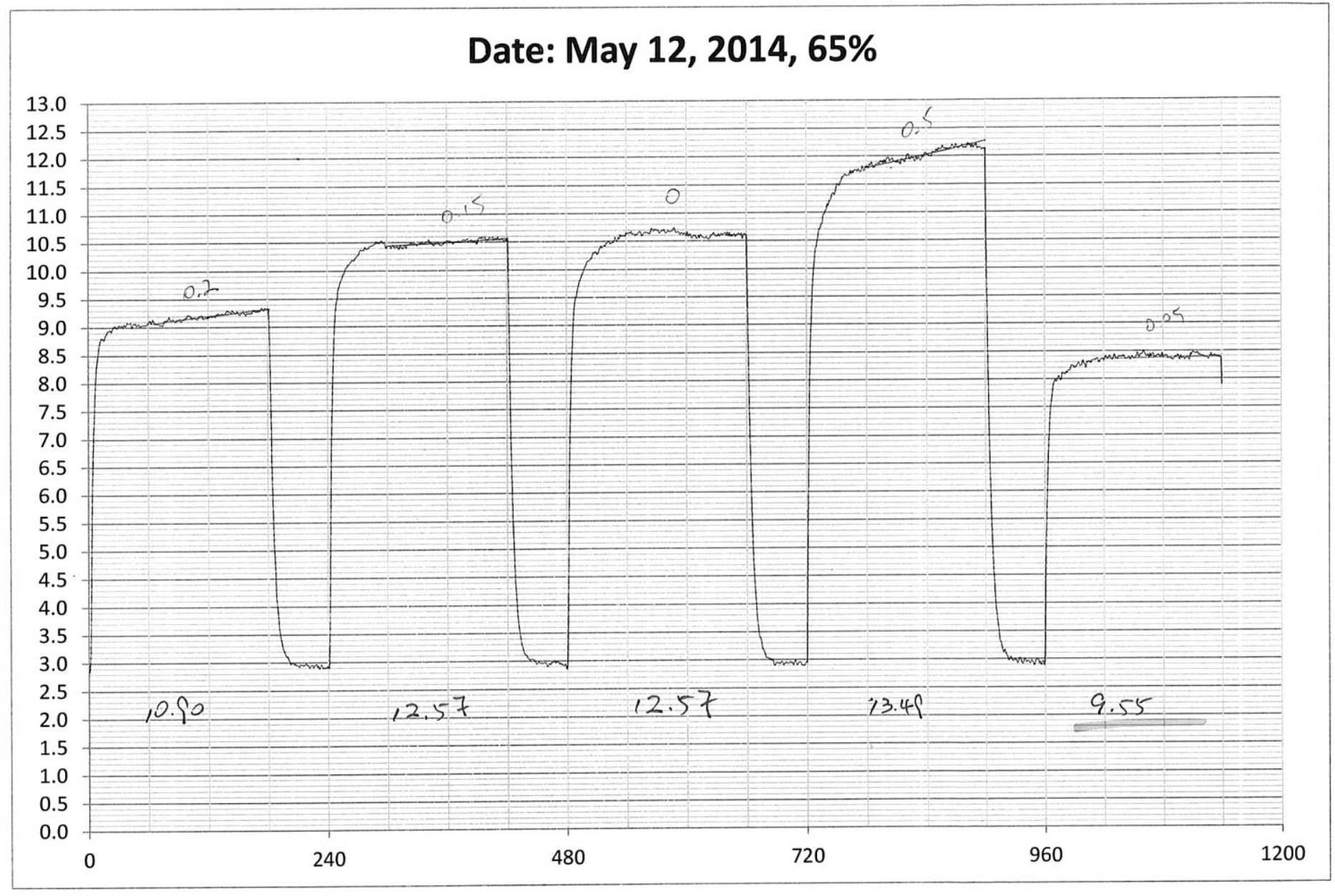




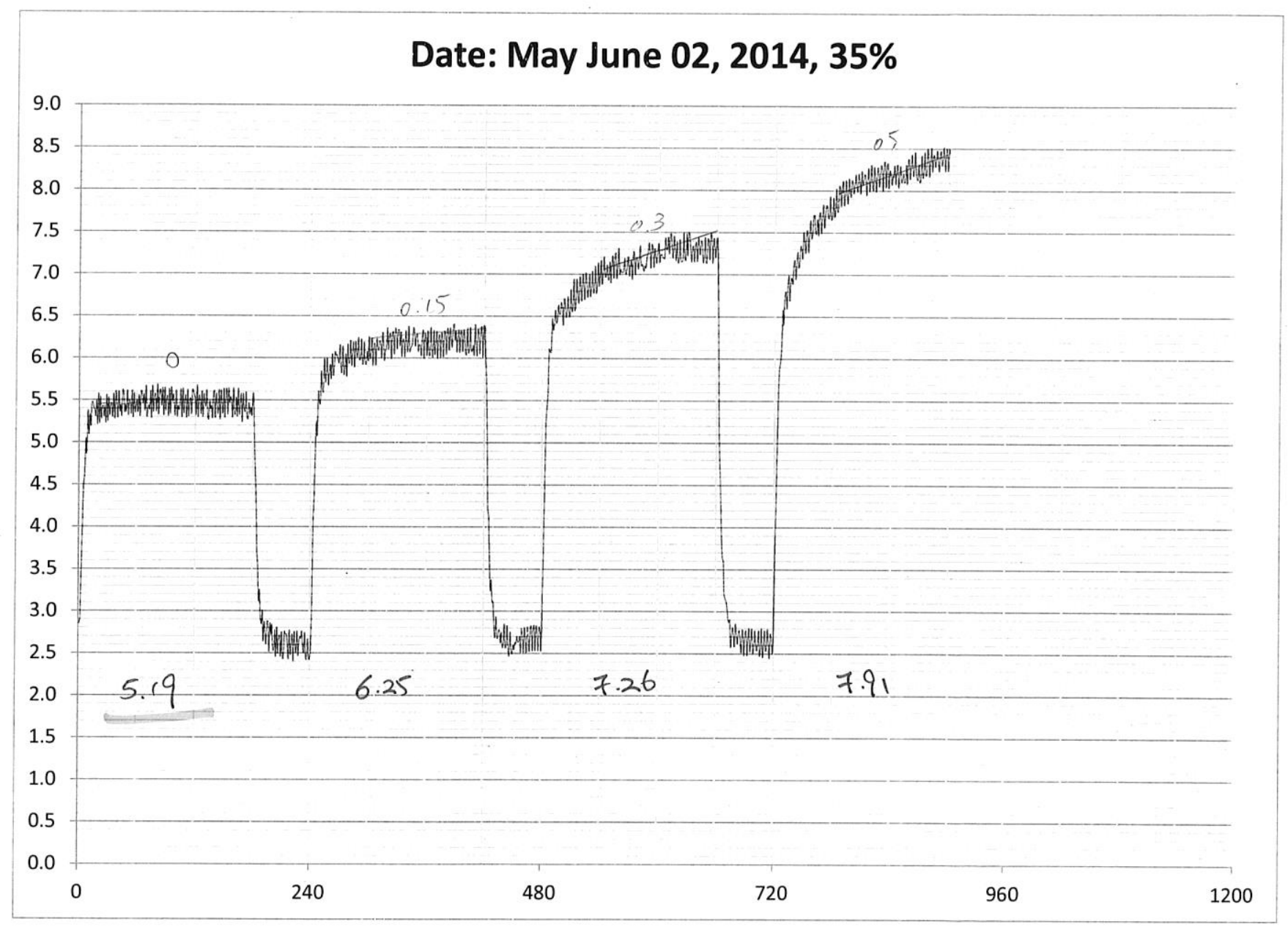

122 


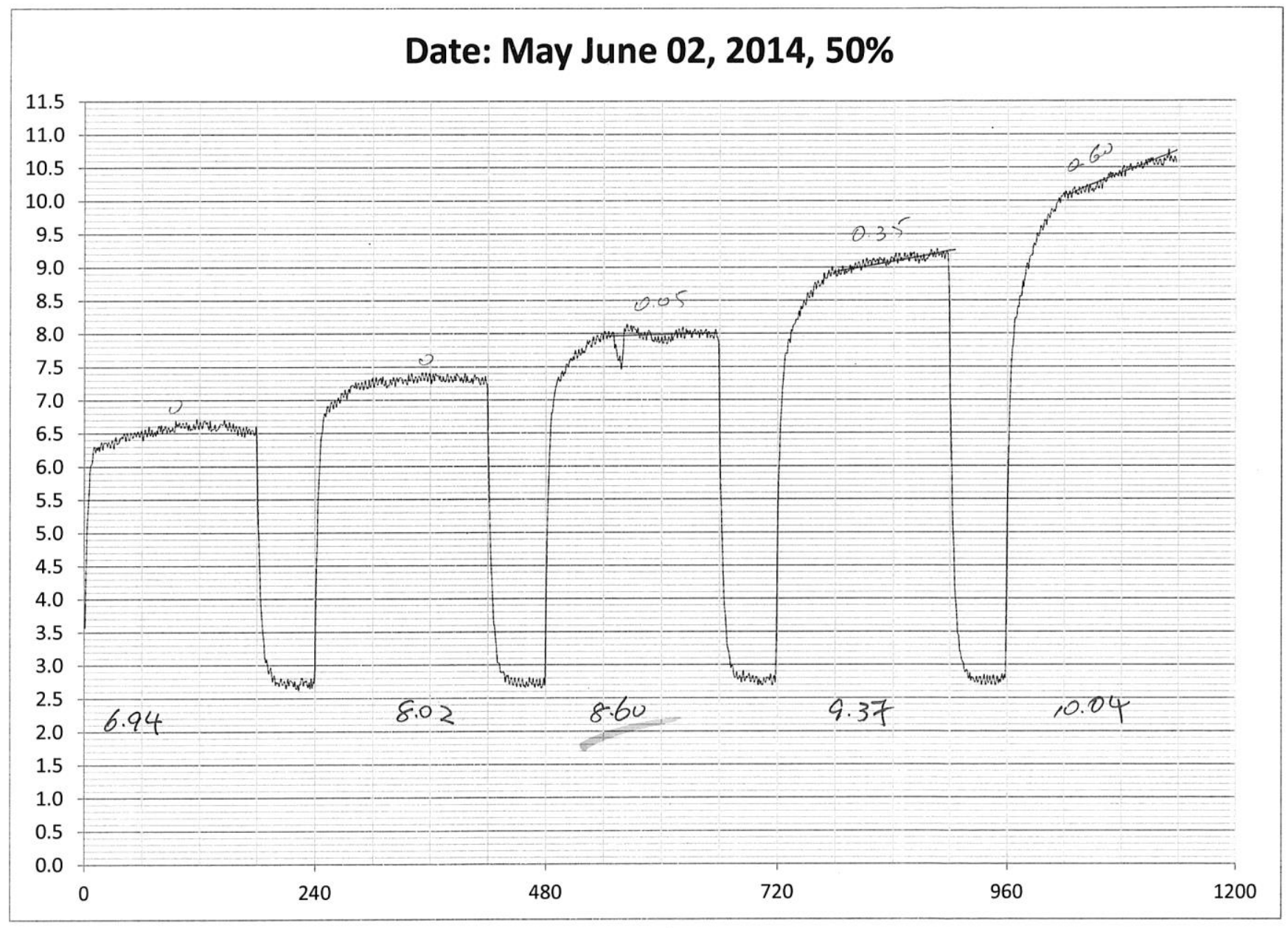

123 


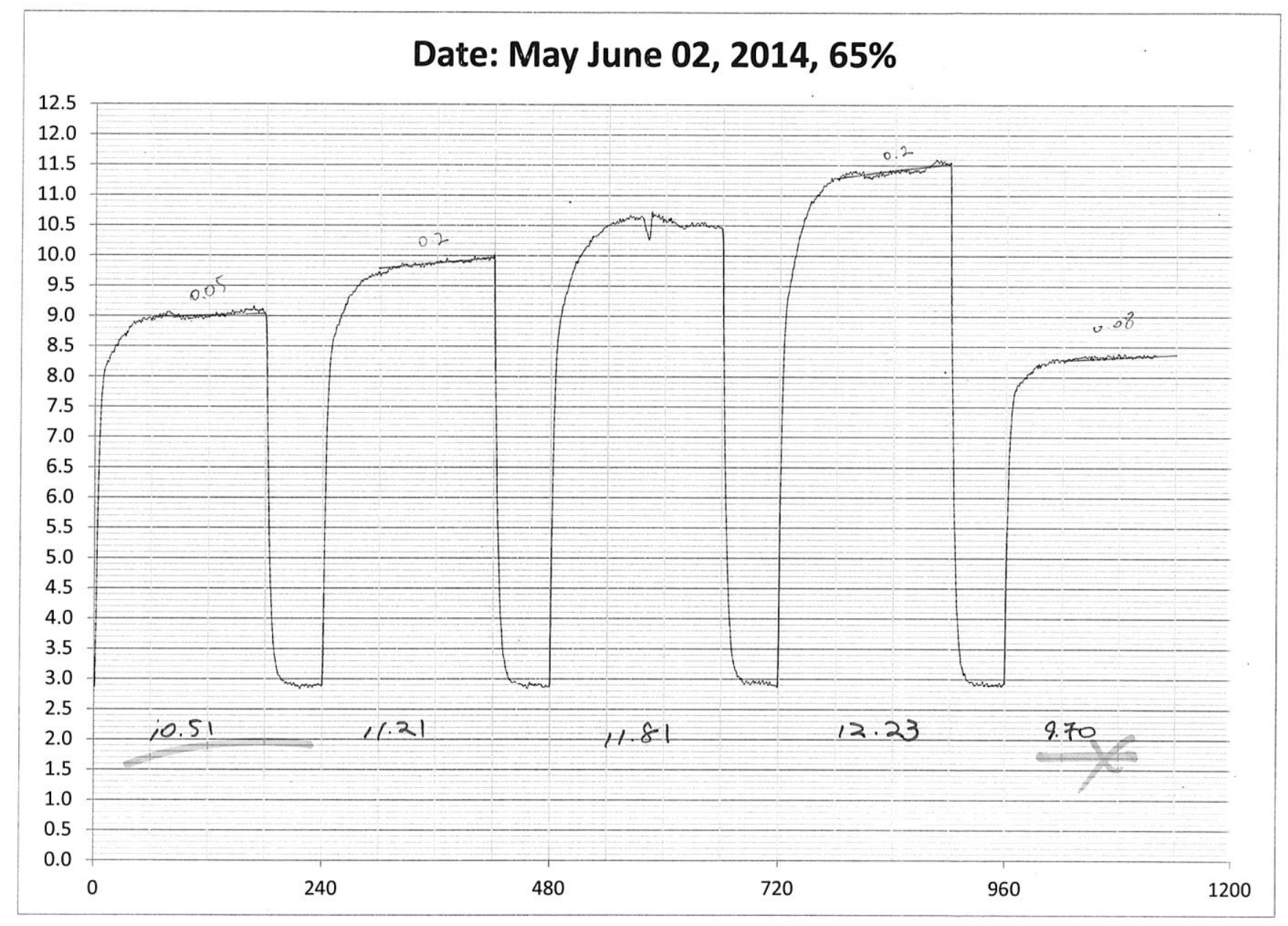




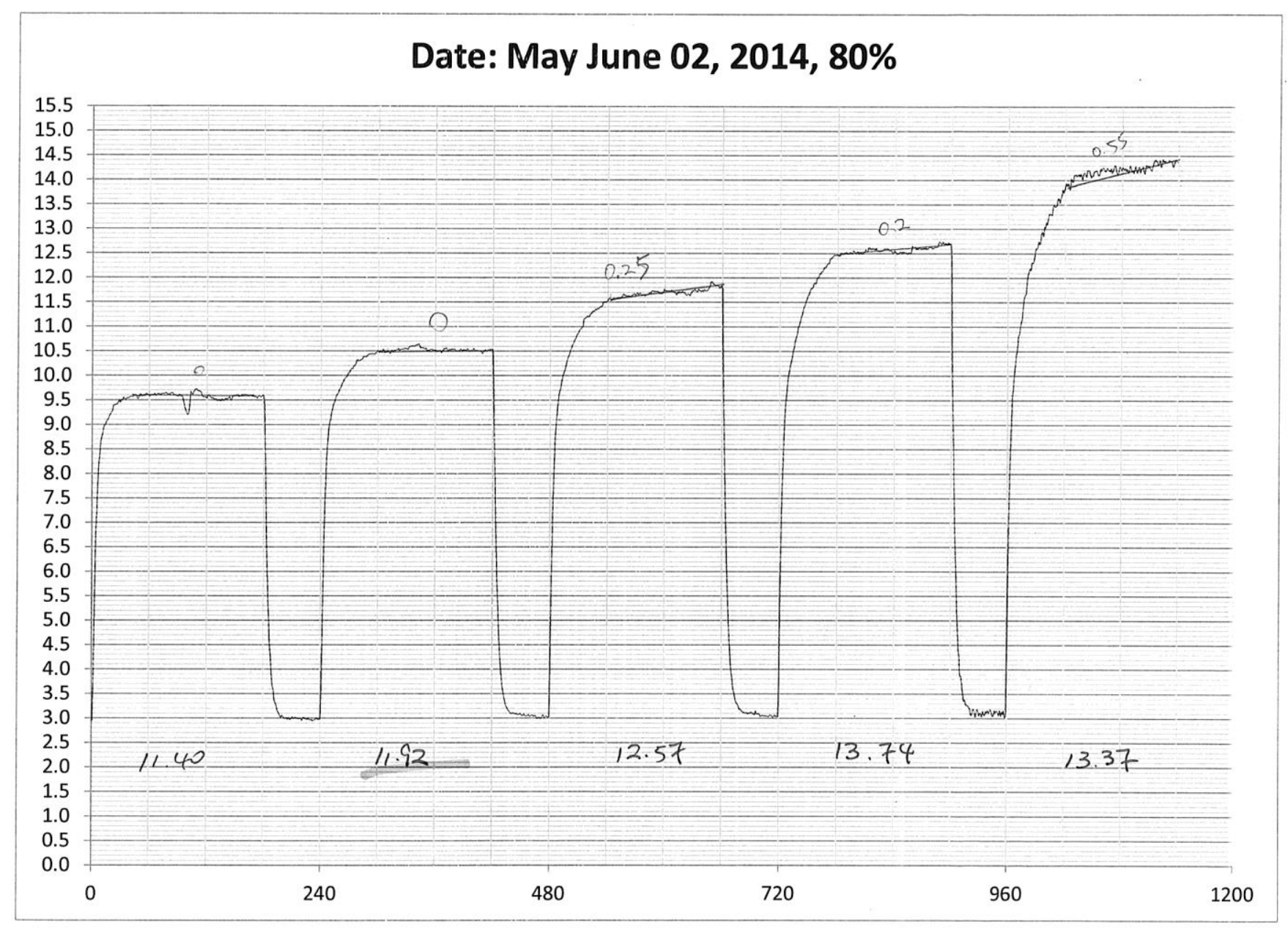

125 


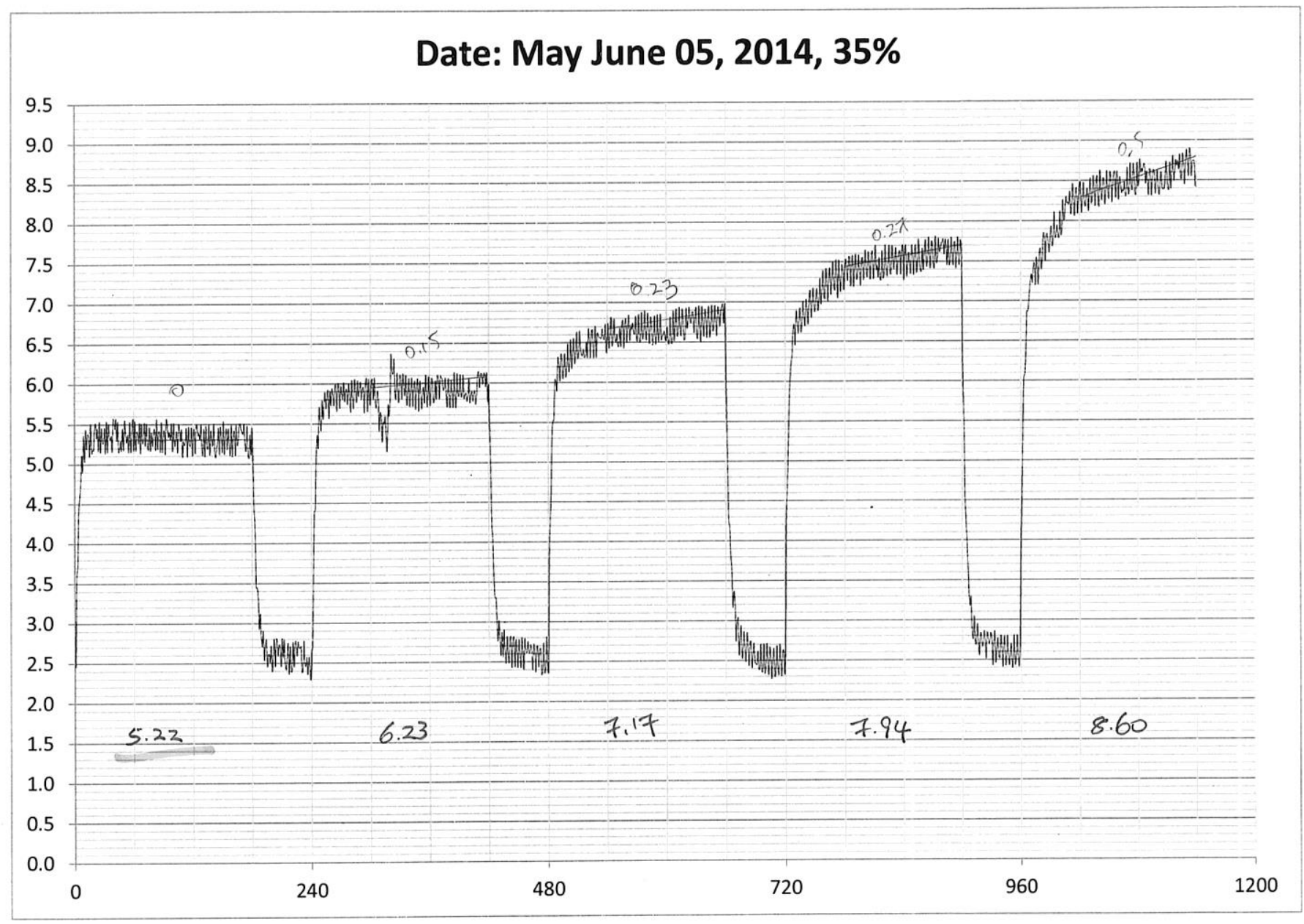




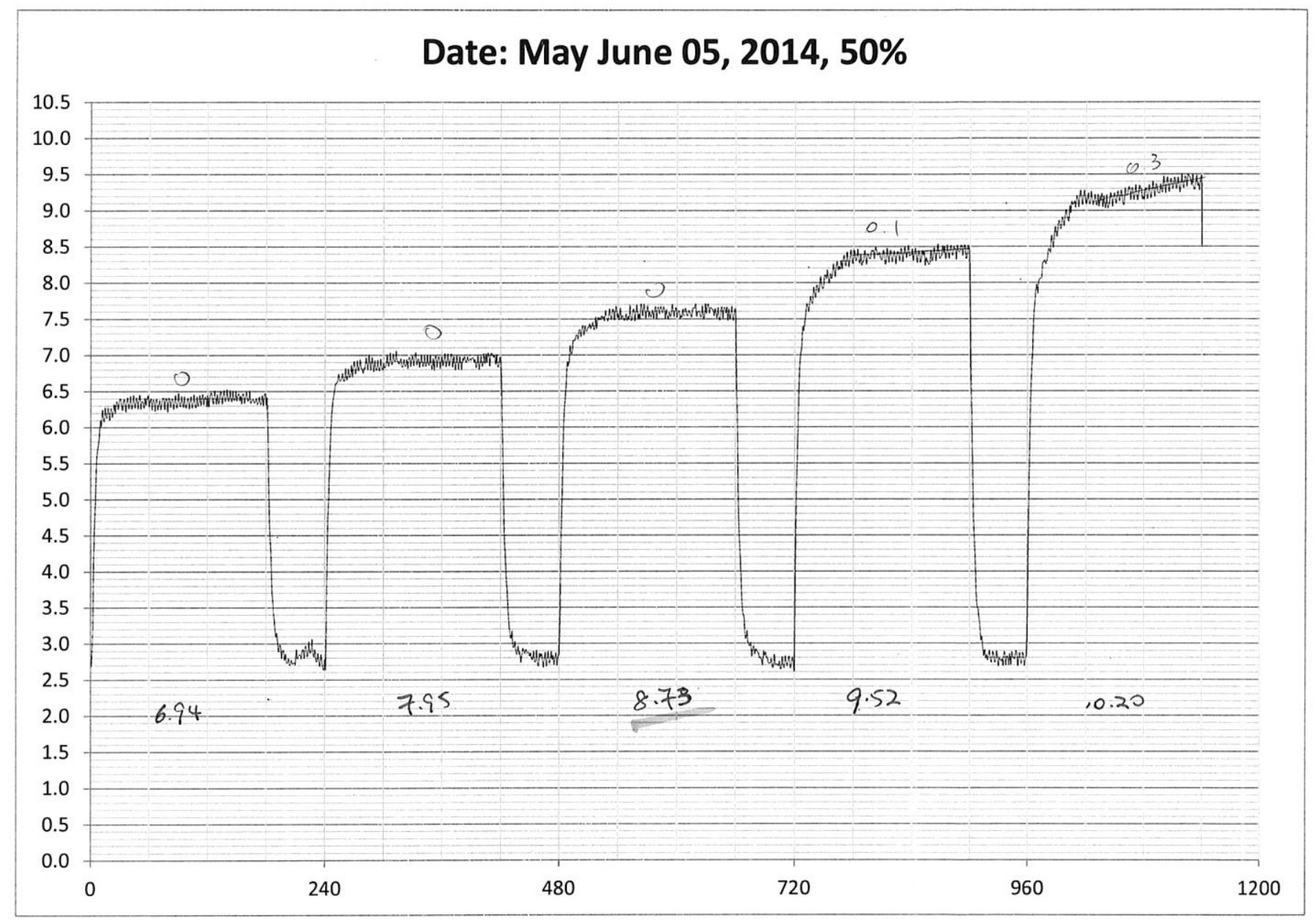




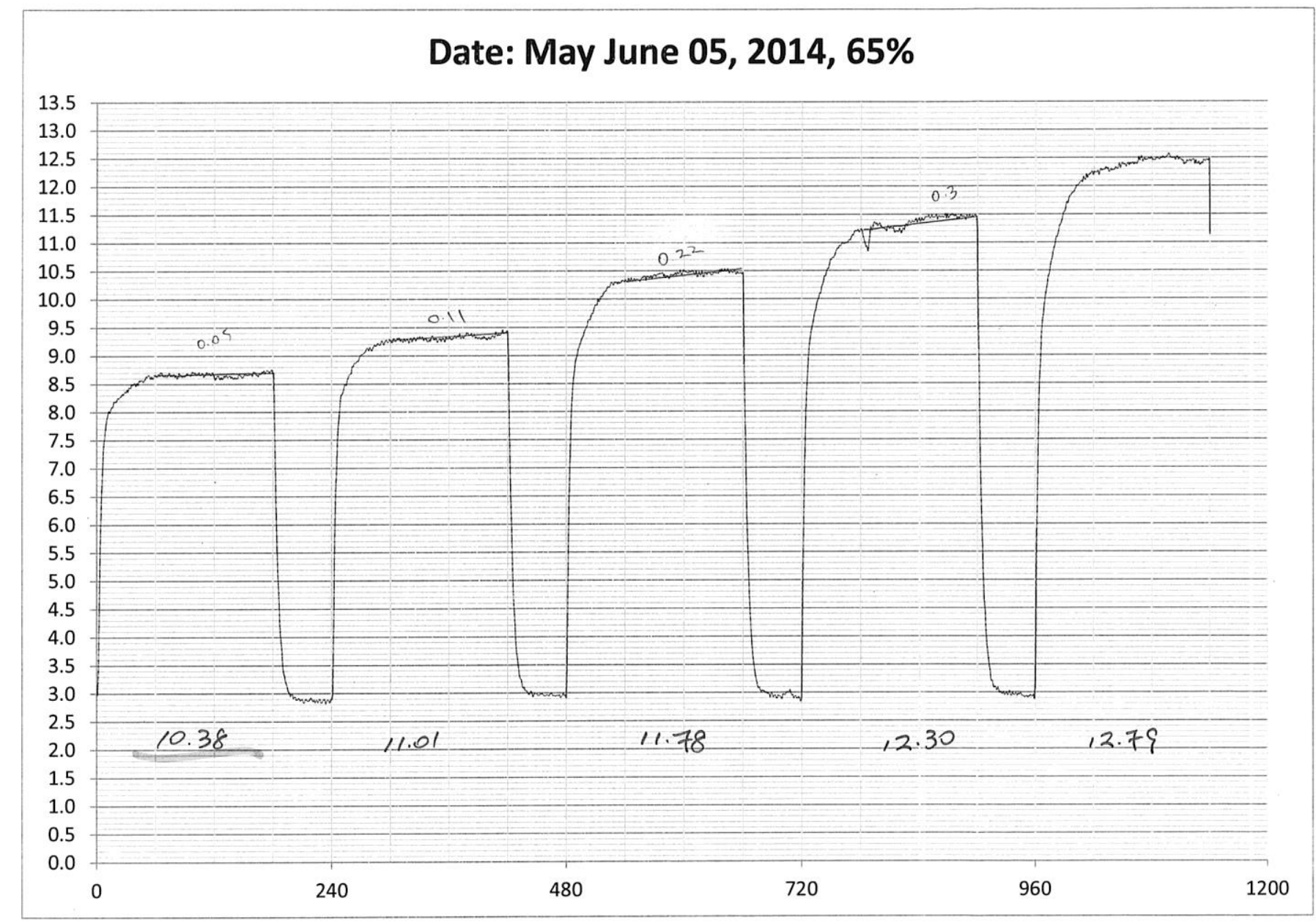




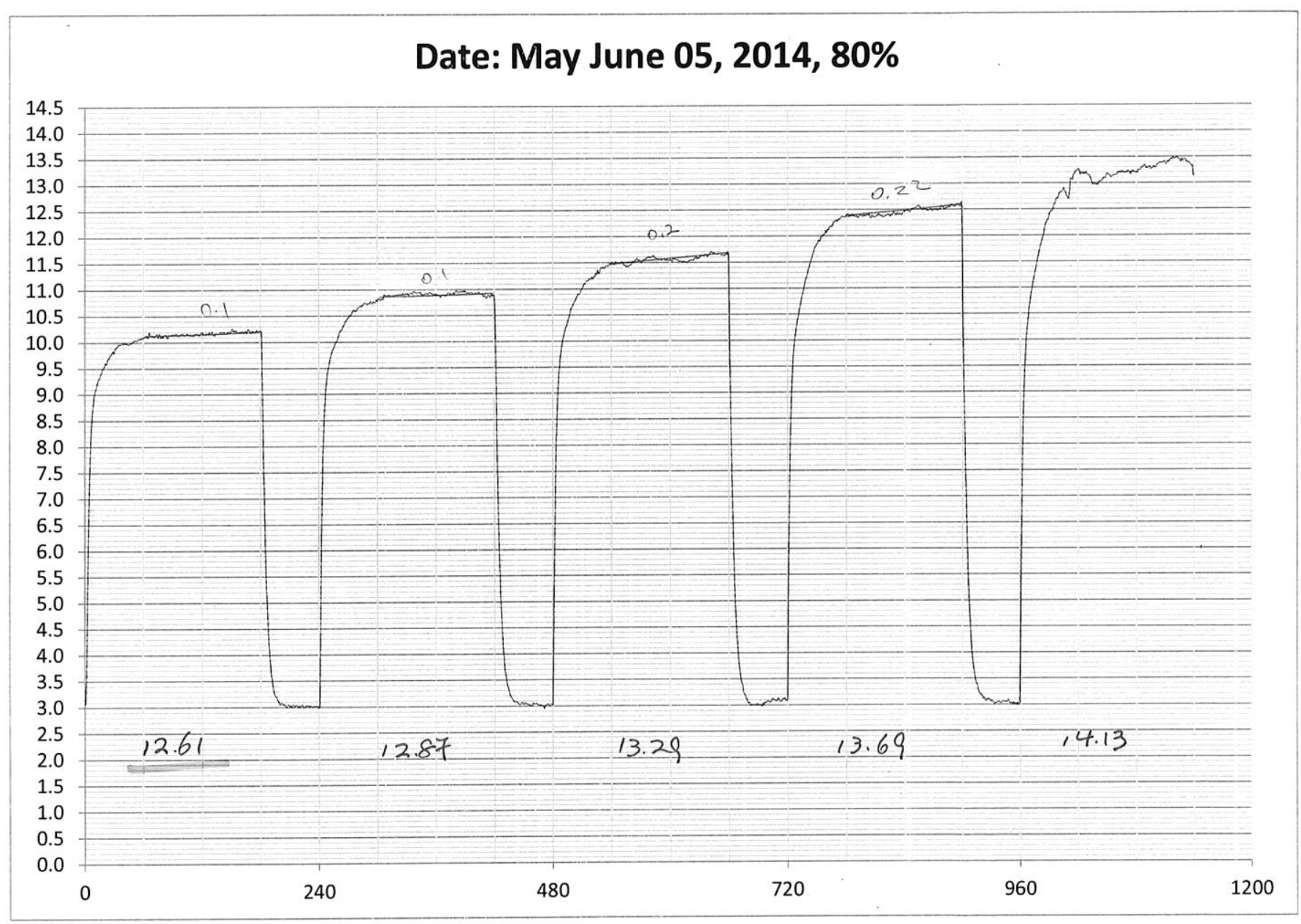


Real Brewery masteveater

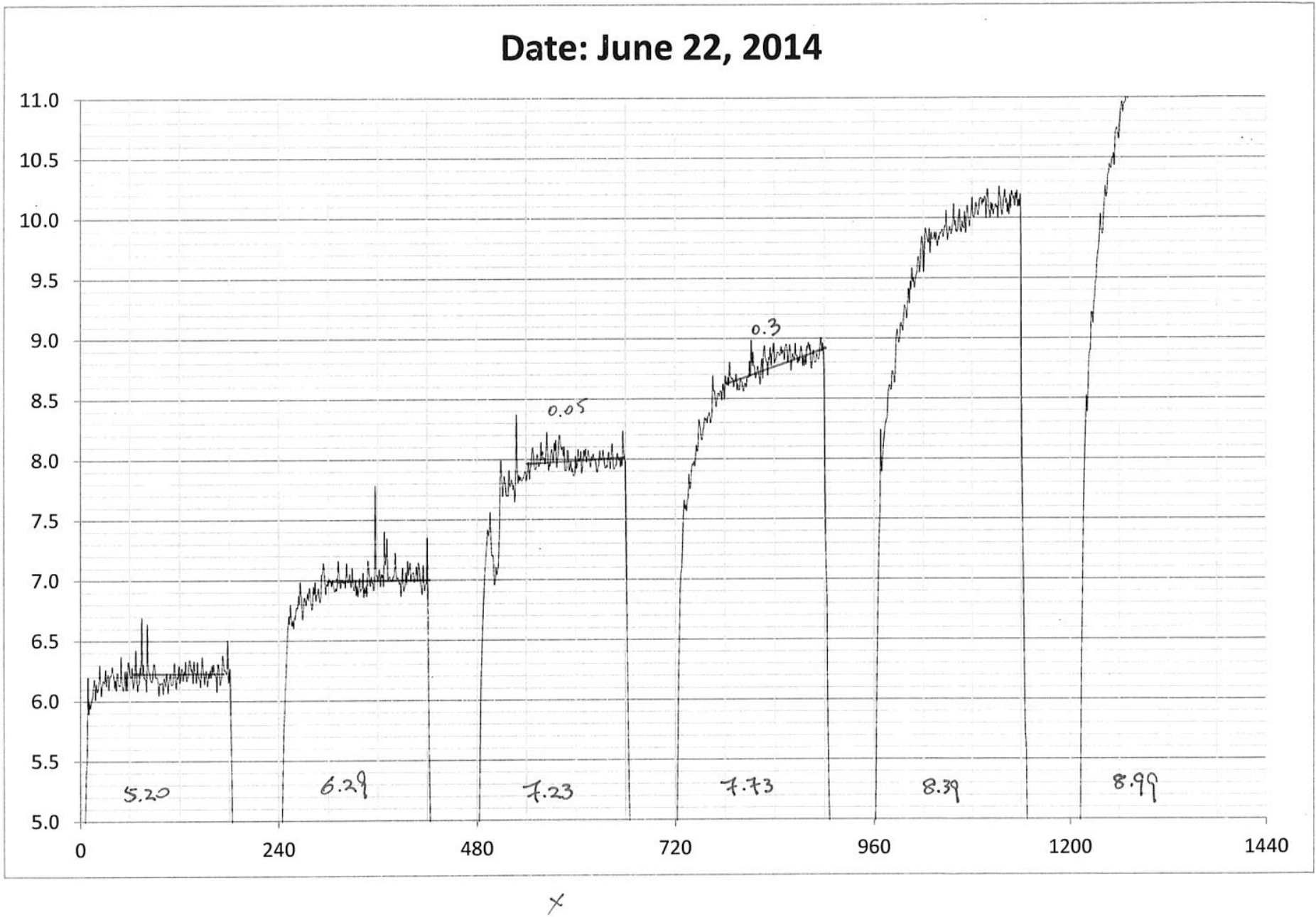


D 26

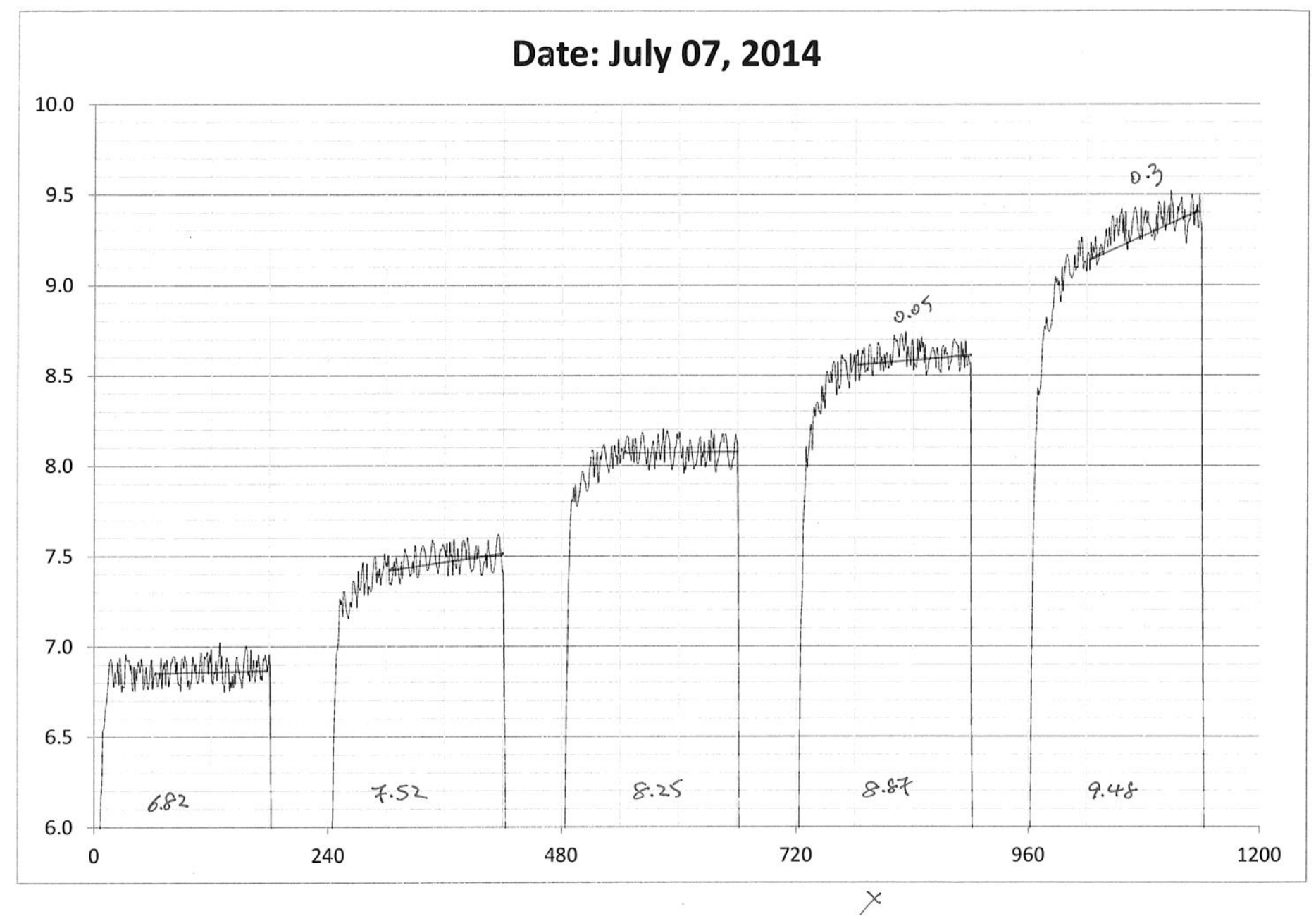

131 


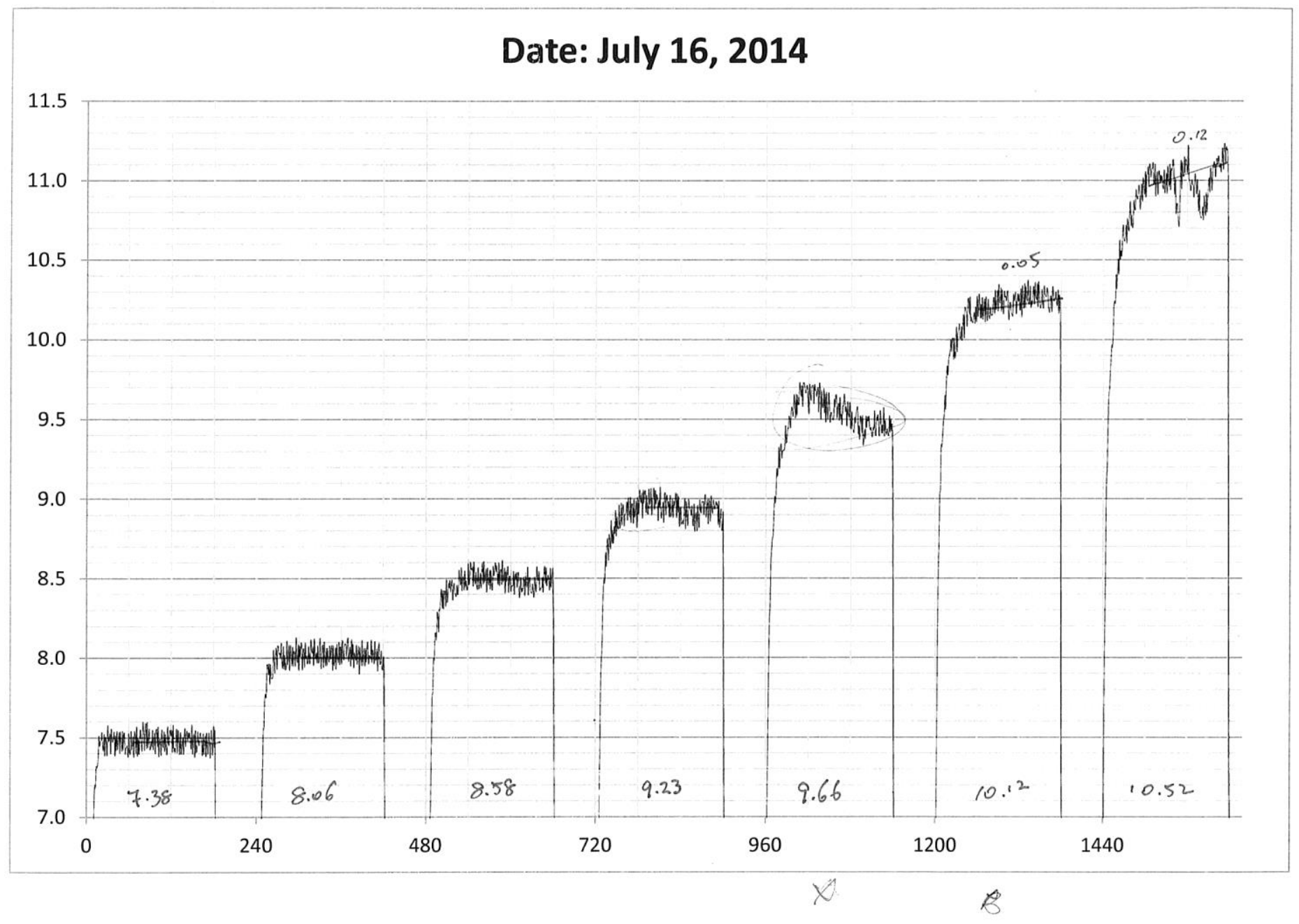


041

Date: July 22, 2014

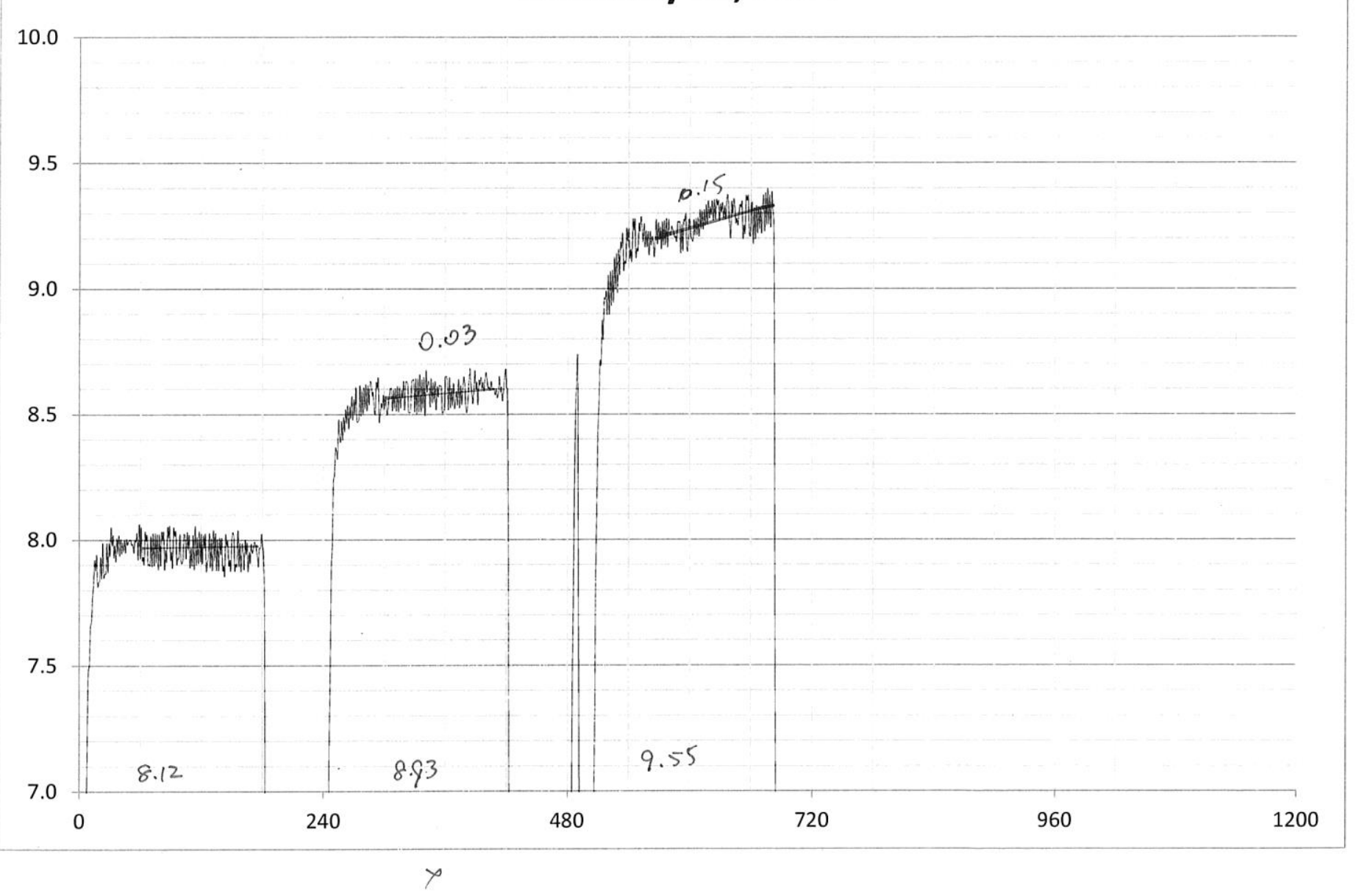

133 


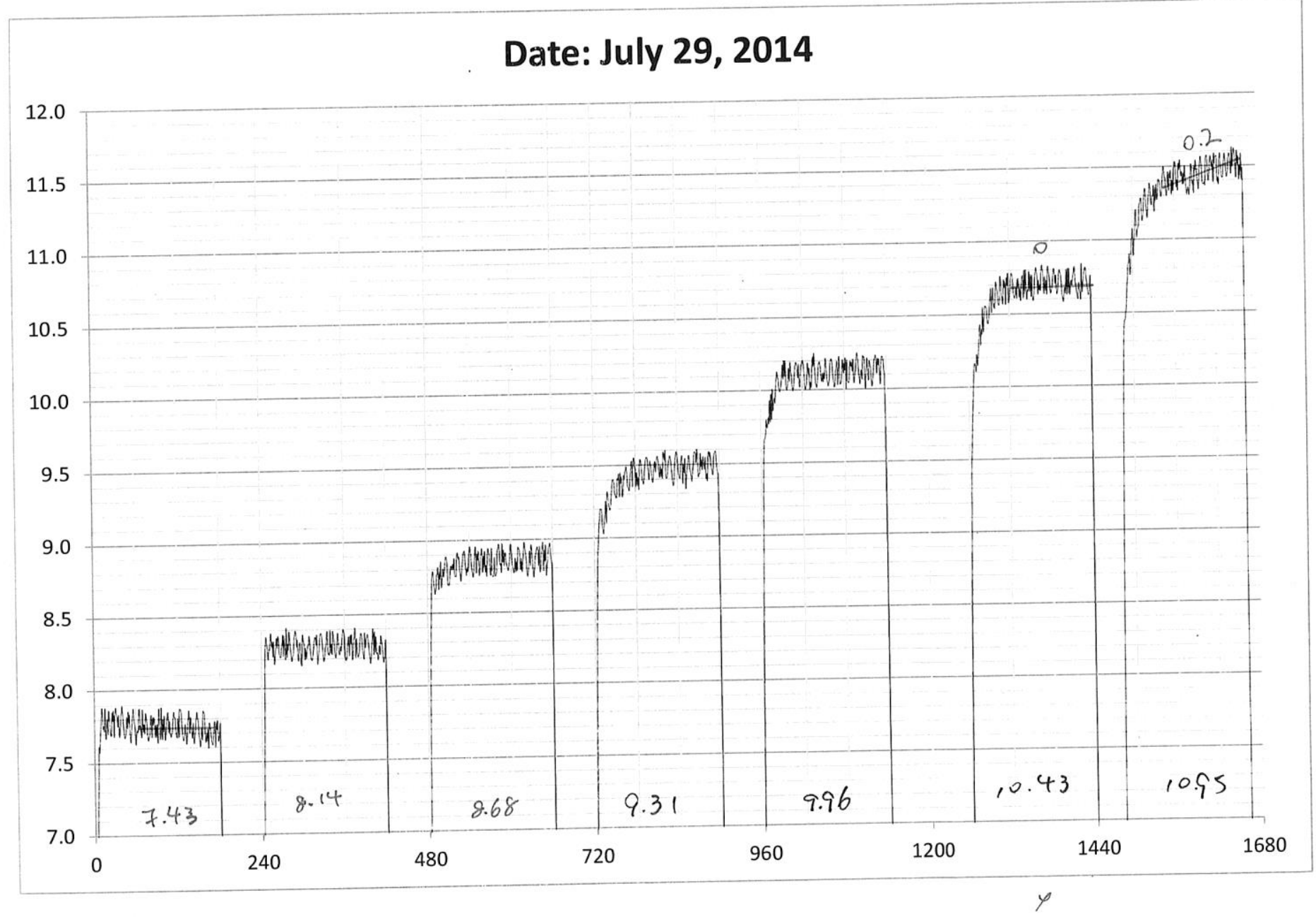


D56

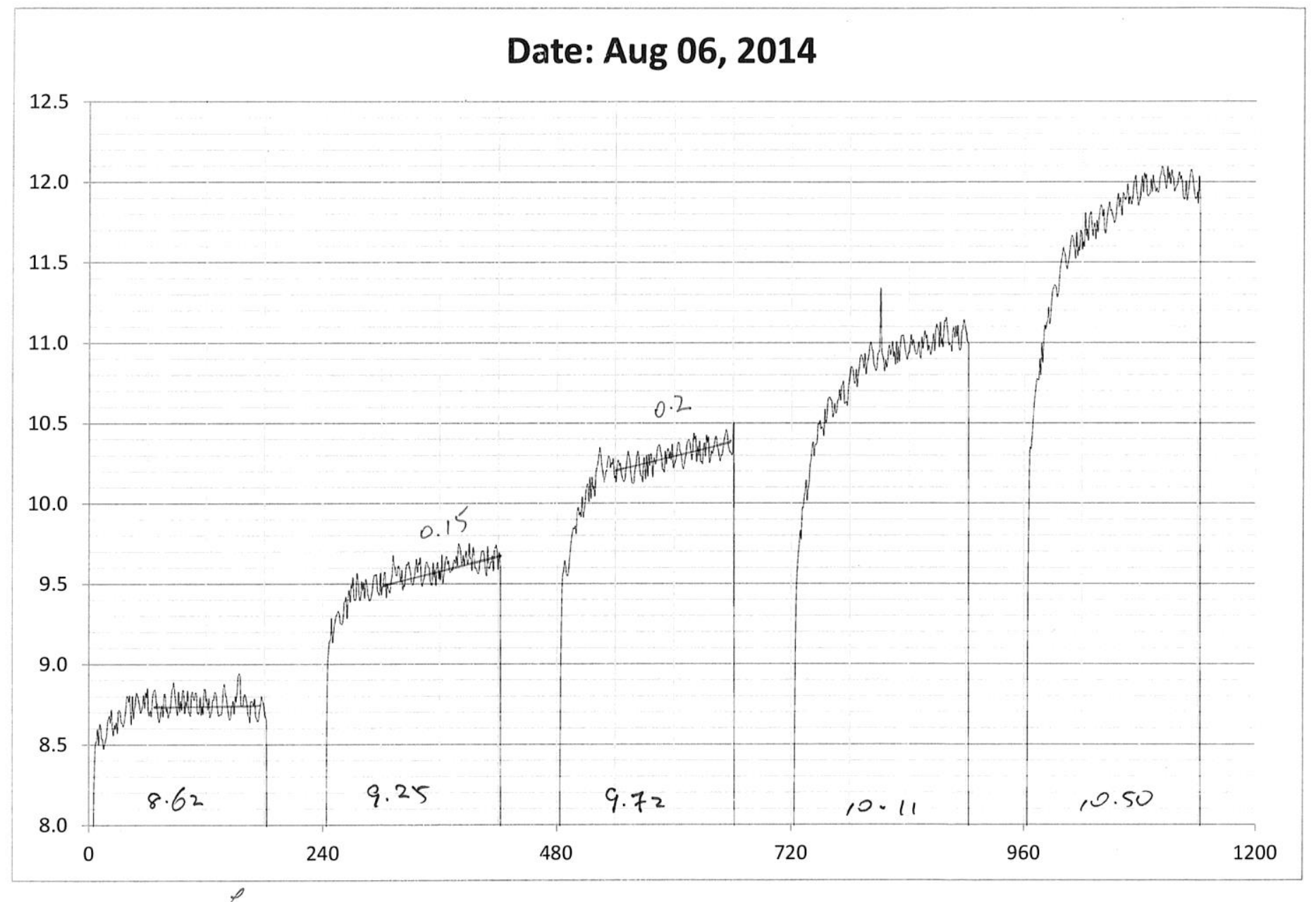

135 
065

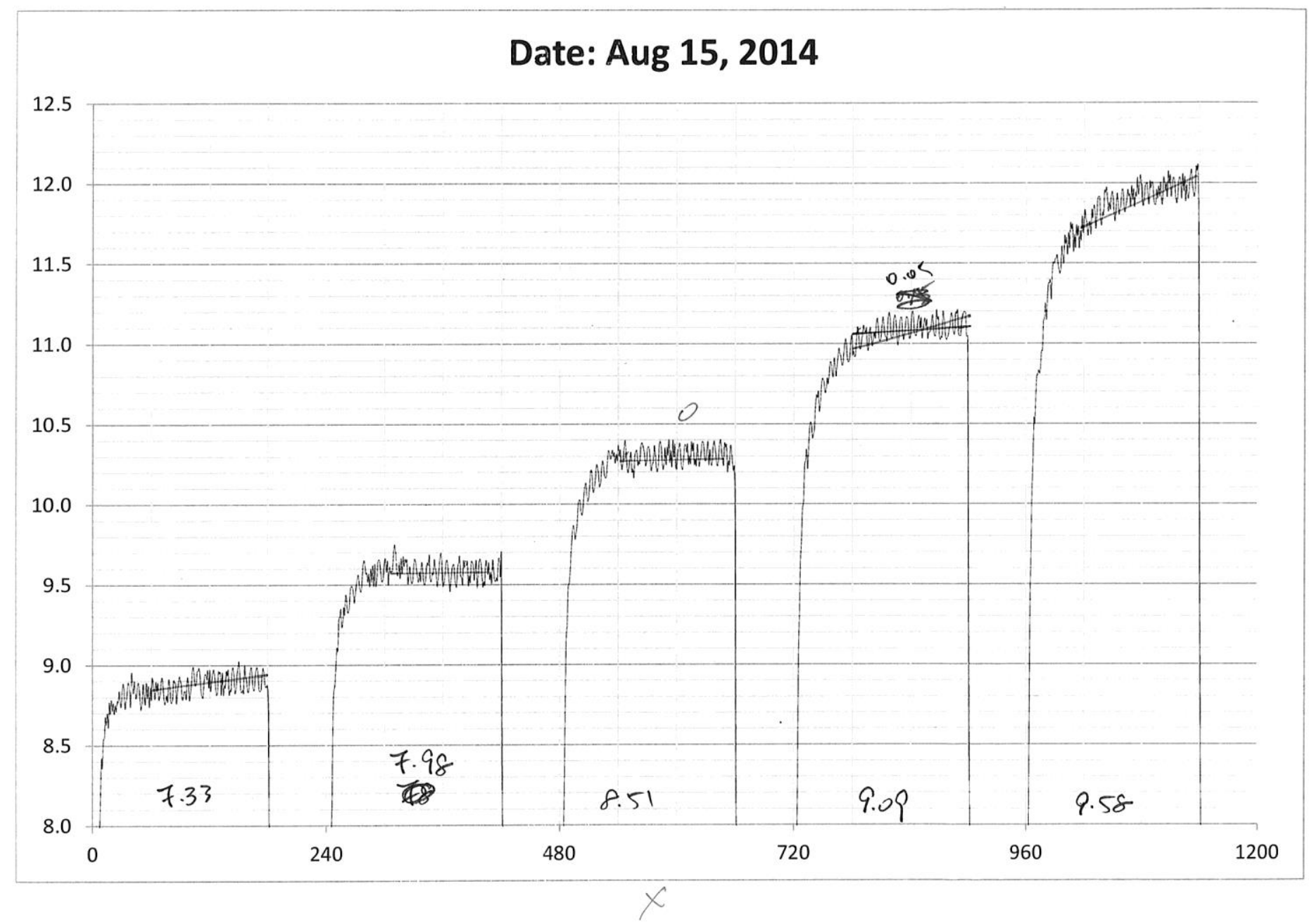

136 
D81

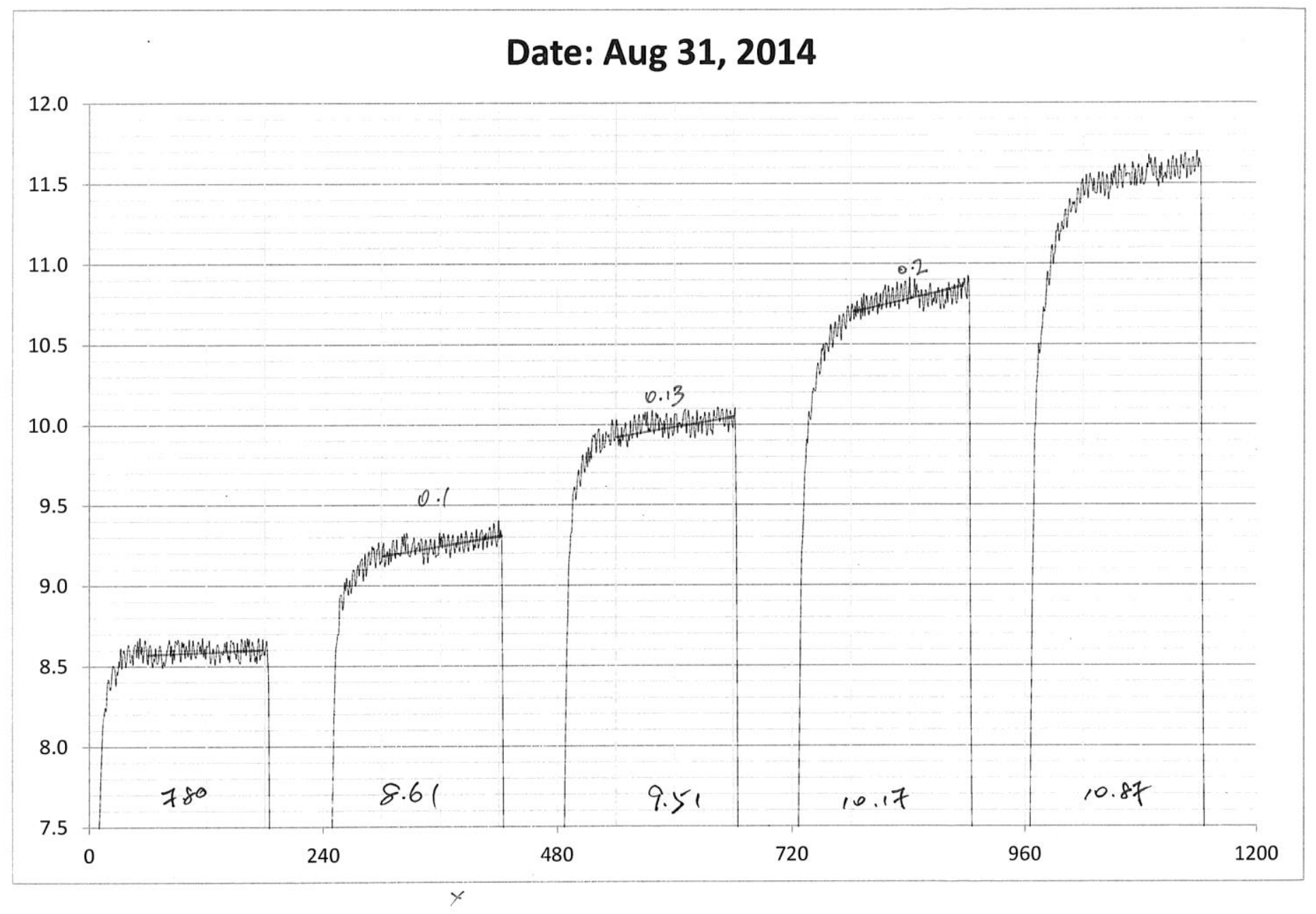

137 


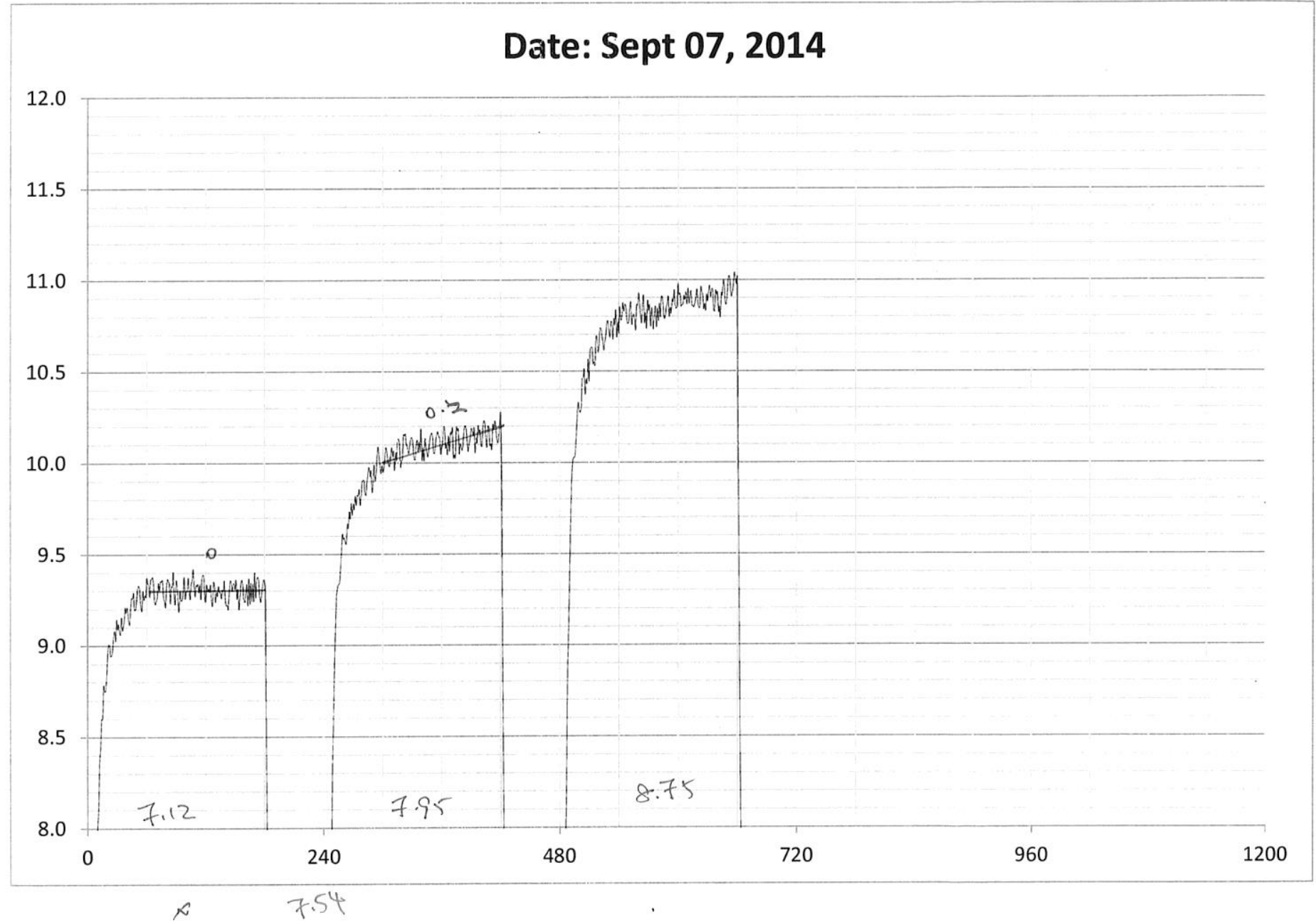


Air sowing effect. (Real)

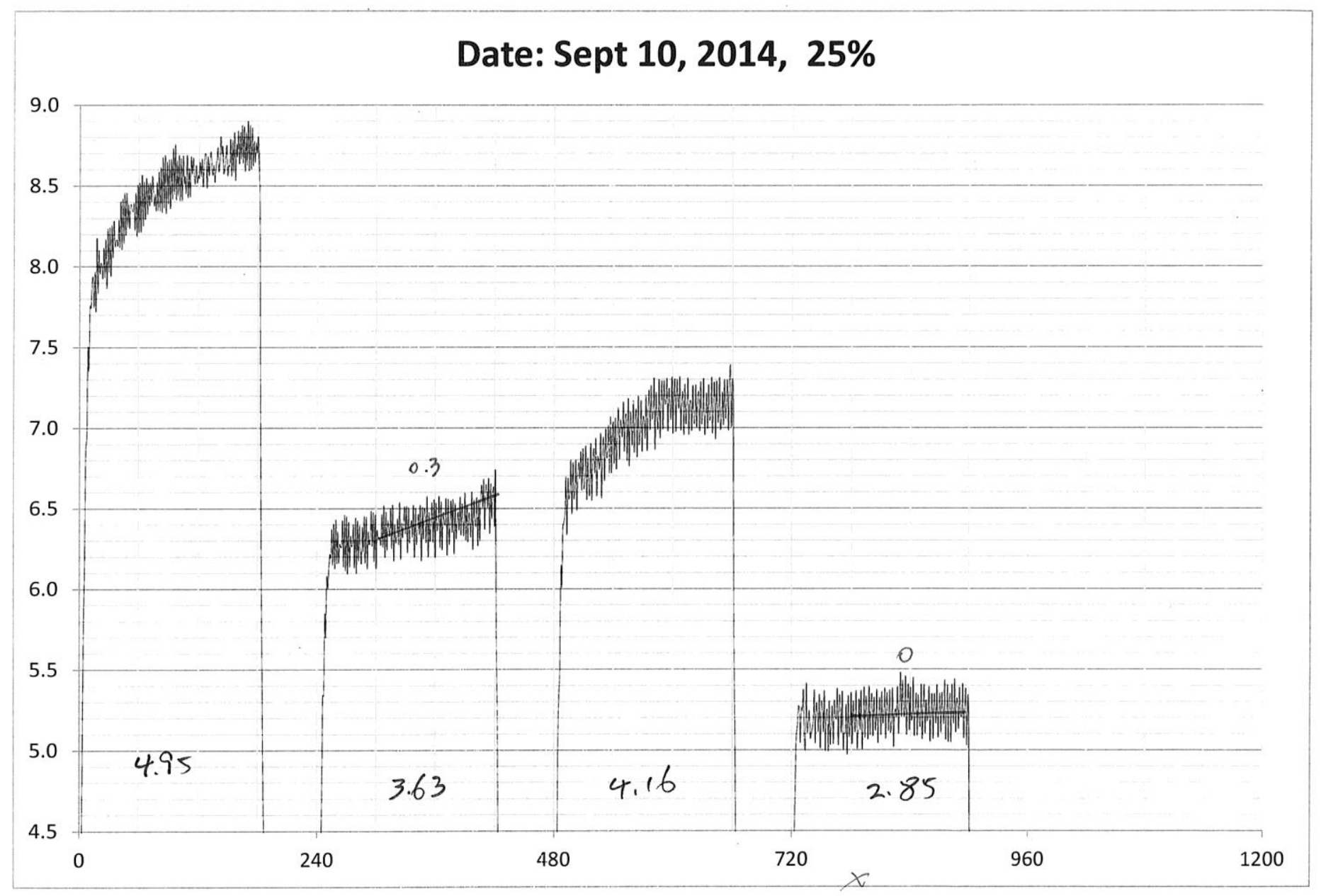

139 


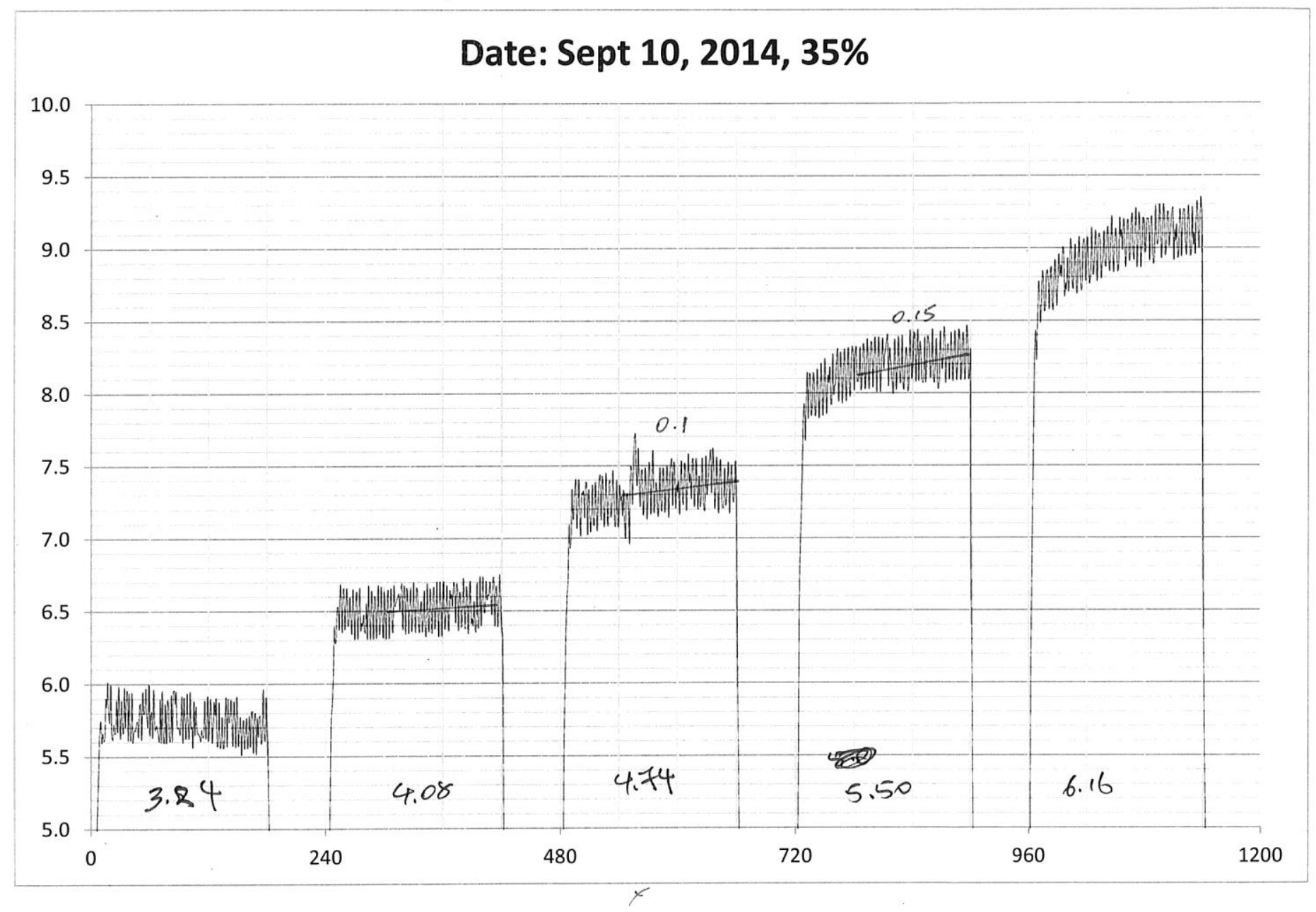

140 


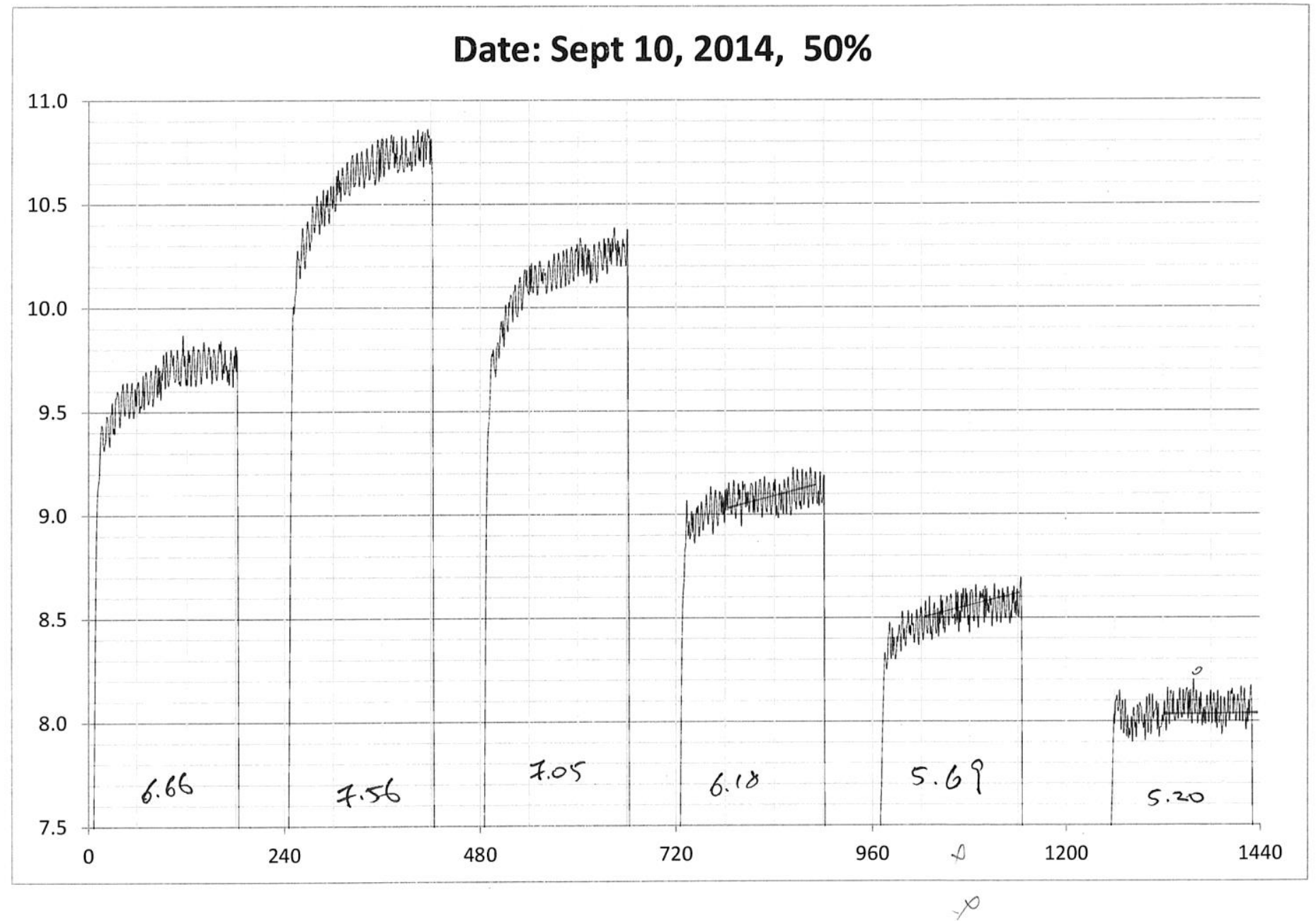




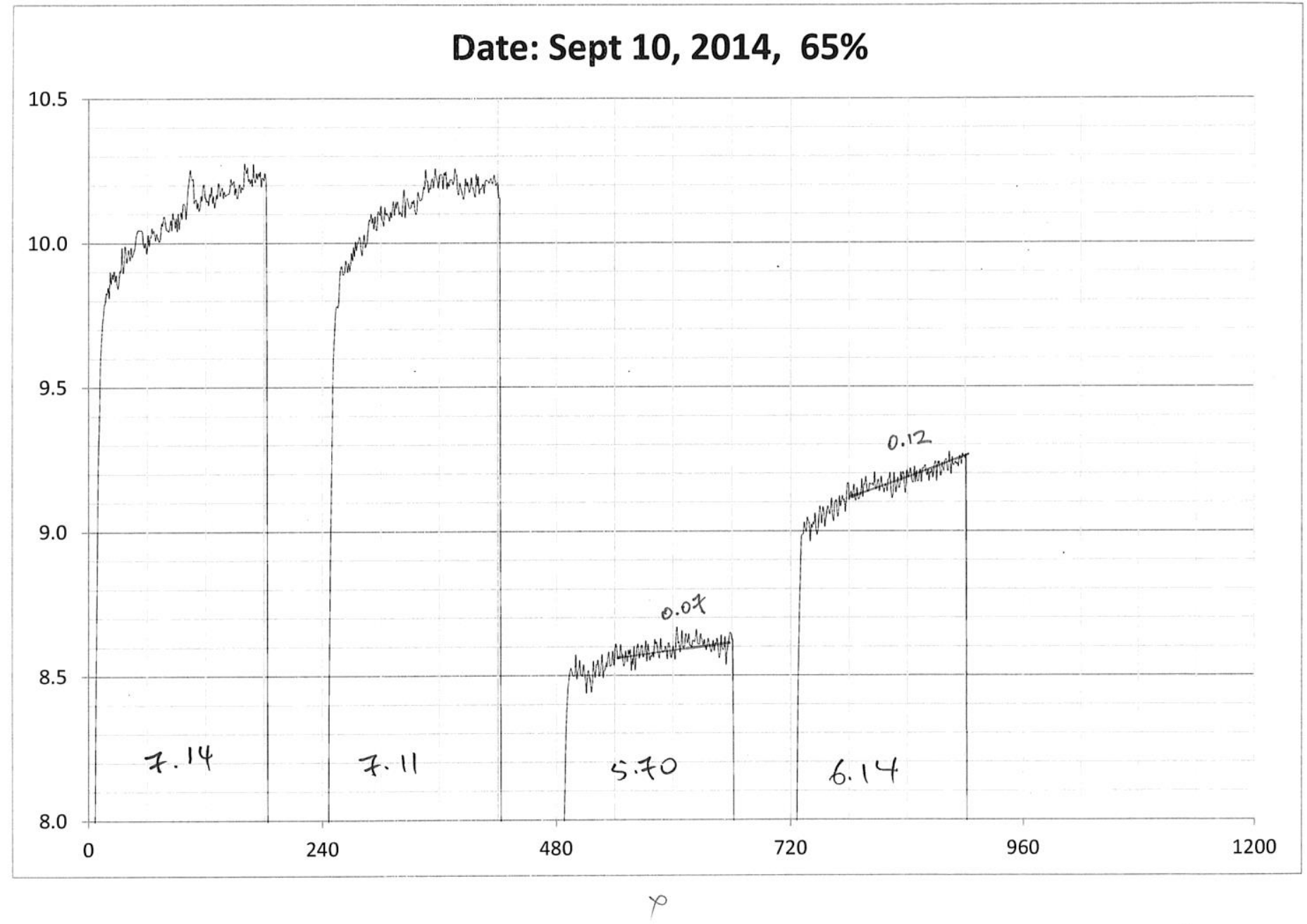




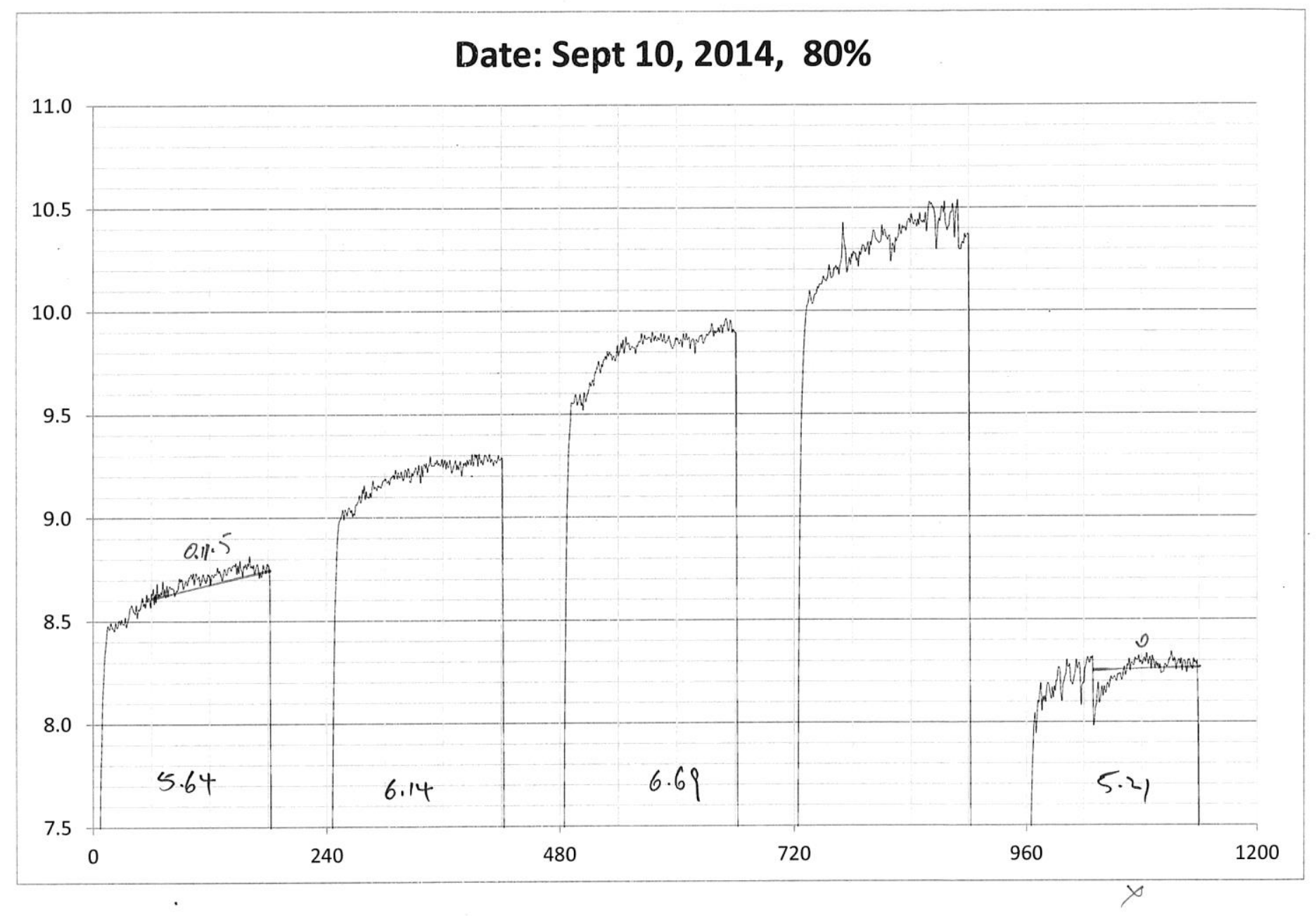

143 
Air scaring effect. (Real)

DPI

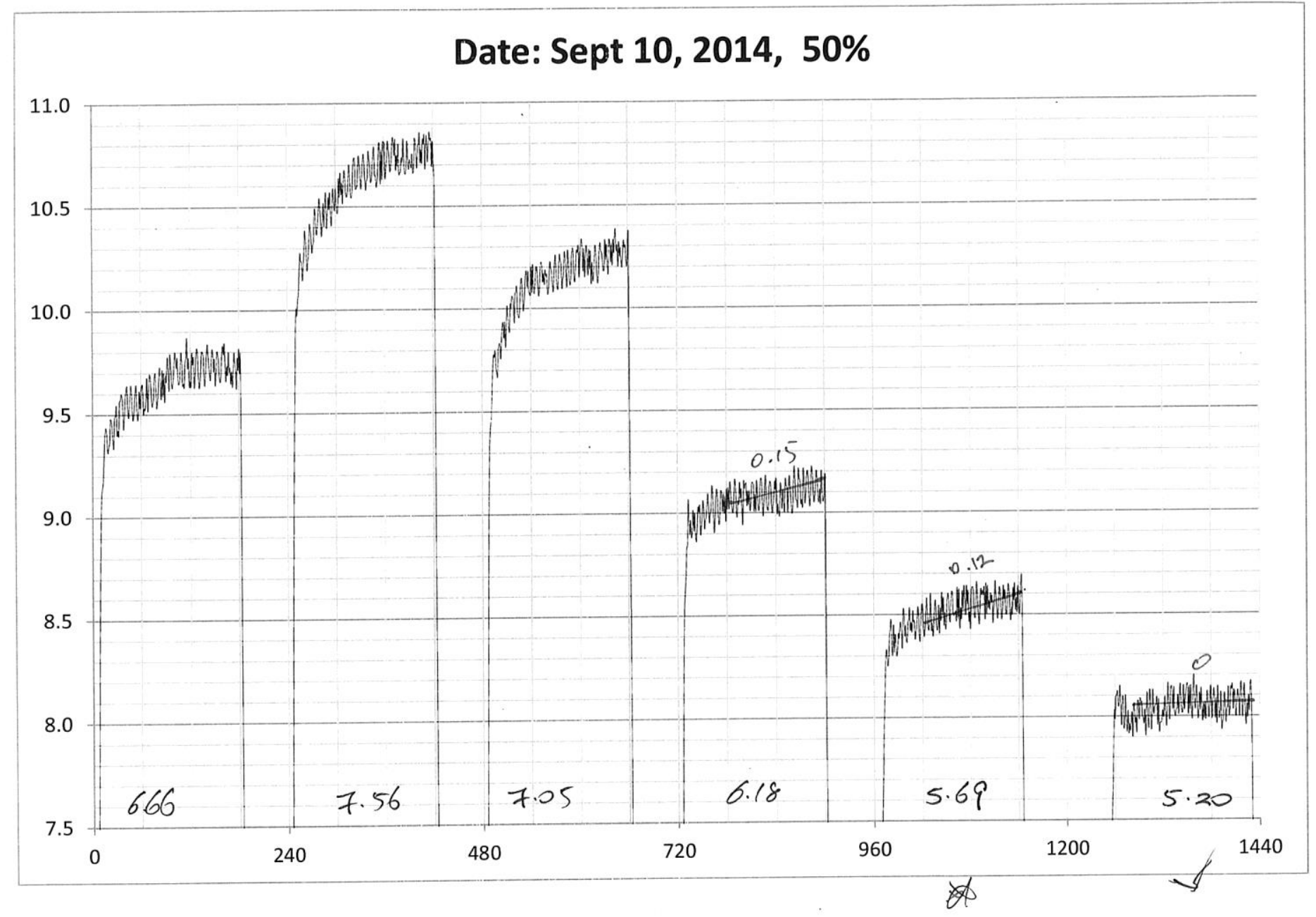

144 